UNIVERSIDADE FEDERAL DO CEARÁ

FACULDADE DE DIREITO

PROGRAMA DE PÓS-GRADUAÇÃO EM DIREITO

FERNANDA KARLLA RODRIGUES CELESTINO

DESJUDICIALIZAÇÃO DO DIREITO À SAÚDE: A EXPERIÊNCIA DO ESTADO DO CEARÁ NA ADOÇÃO DE ESTRATÉGIAS JUDICIAIS E EXTRAJUDICIAIS

FORTALEZA-CE 
DESJUDICIALIZAÇÃO DO DIREITO À SAÚDE: A EXPERIÊNCIA DO ESTADO DO CEARÁ NA ADOÇÃO DE ESTRATÉGIAS JUDICIAIS E EXTRAJUDICIAIS

Dissertação de Mestrado apresentada ao programa de Pós-Graduação em Direito da Universidade Federal do Ceará na área de concentração Ordem Jurídica Constitucional como requisito parcial para a obtenção do Título de Mestre em Direito Constitucional.

Orientador: Prof. Dr. Felipe Braga Albuquerque. 
Dados Internacionais de Catalogação da Publicação Universidade Federal do Ceará 


\title{
DESJUDICIALIZAÇÃO DO DIREITO À SAÚDE: A EXPERIÊNCIA DO ESTADO DO CEARÁ NA ADOÇÃO DE ESTRATÉGIAS JUDICIAIS E EXTRAJUDICIAIS
}

\author{
Dissertação de Mestrado apresentada ao \\ programa de Pós-Graduação em Direito da \\ Universidade Federal do Ceará na área de \\ concentração Ordem Jurídica Constitucional \\ como requisito parcial para a obtenção do \\ Título de Mestre em Direito Constitucional.
}

Aprovada em:

BANCA EXAMINADORA

Prof. Dr. Felipe Braga Albuquerque (Orientador) Universidade Federal do Ceará (UFC)

Prof. ${ }^{a}$ Dr. ${ }^{a}$ Cynara Monteiro Mariano

Universidade Federal do Ceará (UFC)

Prof. Dr. Rosendo Freitas de Amorim

Universidade de Fortaleza (UNIFOR) 
À Deus, sem o qual nada disso seria possível.

Aos meus familiares, fonte de estímulo e perseverança.

Aos meus colegas e amigos da Justiça Estadual, pelo apoio e colaboração.

Aos Colaboradores Especiais, Doutores:

Felipe Braga Albuquerque, Cynara Monteiro Mariano, Rosendo Freitas de Amorim, que fizeram dessa dissertação uma realidade. 


\section{AGRADECIMENTOS}

Primeiramente a Deus, que com sua infinita misericórdia, sempre iluminou os meus passos como ser humano, estudante e profissional.

À minha querida mãe Flávia, por seu amor e apoio incondicionais, pessoa cuja fé em meu potencial me faz perseverar.

À Teni Júnior, por todo seu apoio e companheirismo. Ele que sempre me incentivou com palavras otimismo, tendo festejado a cada etapa vencida, desde a aprovação no processo seletivo de ingresso no programa de Mestrado da Universidade Federal do Ceará (UFC), a cada artigo aprovado para publicação, bem como em todas as apresentações de seminários que ocorreram ao longo do curso.

Aos meus colegas de profissão, servidores da Central de Mandados e especialmente aos Oficiais de Justiça do Tribunal de Justiça do Estado do Ceará, lotados na Comarca de Maracanaú, que por sempre contarem com palavras de incentivo, ajudaram para que a pesquisa se concretizasse.

Ao querido e renomado orientador Professor Doutor Felipe Braga Albuquerque, o qual desde o processo seletivo já elegi como pessoa a cumprir esse mister, tendo em vista seu notório saber jurídico no conteúdo específico da pesquisa, que aceitou cordialmente o convite e sempre se mostrou disponível, sendo sua orientação e seus comentários construtivos essenciais para o direcionamento e conclusão mesma.

Aos respeitosos doutores Cynara Monteiro Mariano e Rosendo Freitas de Amorim, que gentilmente concordaram em compor a banca examinadora, pessoas cujo rigor científico e considerações por ocasião da qualificação e ao longo da presente pesquisa a acresceram em muito em qualidade.

Às solidárias Marilene e Heloísa, funcionárias dedicadas da coordenação da Pósgraduação Stricto Sensu, que demonstraram bastante cuidado com as questões administrativas acadêmicas, bem como apoio e satisfação ao vê-las sendo concluídas com sucesso.

Aos membros e funcionários do Núcleo de Defesa da Saúde (NUDESA), do Núcleo de Apoio Técnico ao Poder Judiciário (NATJUS-CE) e da Secretaria de Saúde do Estado do Ceará (SESA) que contribuíram para esta pesquisa. À Cecília Barreto, Ivoneide Vital e Juliana Pedrosa, que com suas palavras de apoio ao longo do curso e suas orientações me ajudaram a ter plena confiança em meu potencial como pesquisadora e na pesquisa como um todo. A todos que de alguma forma contribuíram para o êxito do presente trabalho. 


\section{RESUMO}

A judicialização da saúde se institucionalizou e na atualidade constitui mais uma forma de acesso ao Sistema Único de Saúde (SUS). Contudo, a concretização dos direitos fundamentais não pode se dar prioritariamente por esta via. A compreensão da natureza dúplice do direito à saúde fortalece o entendimento do seu caráter objetivo, que expende deveres objetivos ao Poder Público, devendo ser concentrados esforços no aprimoramento de sua prestação voluntária com foco nos procedimentos necessários e nas estruturas organizacionais. Constituem caminhos para efetivar o direito à saúde, racionalizando e reduzindo sua judicialização, respectivamente, a criação de parâmetros decisórios mais formais e o aprofundamento do processo de interação entre os agentes do sistema jurídico, administrativo e sanitário, através de mecanismos de diálogo institucional. Com o intuito de um maior aprofundamento das medidas de mobilização pela desjudicialização, considerando a perspectiva dos vários atores envolvidos, a presente pesquisa volta-se para o estudo das estratégias judiciais e extrajudiciais utilizadas para conter a excessiva judicialização da saúde, com ênfase nas experiências desenvolvidas no Estado do Ceará, sustentando a desjudicialização como alternativa ao ativismo judicial. Partindo-se dessas considerações, o objetivo geral do presente estudo consiste em analisar o panorama da judicialização da saúde no Estado do Ceará e compreender como o estabelecimento de medidas de desjudicialização consegue fornecer soluções satisfatórias para tal problema, contribuindo para uma política de saúde pública mais eficaz e facilmente acessível. Para isso, foi desenvolvida uma estratégia metodológica que se utilizou de técnicas quantitativas e qualitativas de produção, coleta e análise de dados. A pesquisa foi exploratória e desenvolvida com base na análise jurisprudencial no âmbito do Tribunal de Justiça do Estado do Ceará, com a finalidade de construir um perfil dos litígios em saúde pública, buscando categorizá-los mediante variáveis como: autor, réu, bem de saúde demandado, existência da antecipação de tutela, argumentação da decisão judicial, ações coletivas e individuais. Além da coleta desses dados, o estudo também teve como foco analisar a política judiciária de saúde e algumas experiências de efetivação do direito à saúde no Estado do Ceará a respeito dos arranjos institucionais desenvolvidos para a ampliação do direito à saúde. Para tanto, além da pesquisa bibliográfica, foram visitados a Secretaria de Saúde do Estado do Ceará (SESA), o Núcleo de Defesa da Saúde (NUDESA) e o Núcleo de Apoio Técnico ao Judiciário (NATJUS-CE) para coleta de dados junto às instituições. Foram utilizadas tabelas para uma melhor análise e sistematização dos resultados. Dentre os resultados encontrados, ressalte-se no tocante à judicialização no Estado do Ceará a predominância da litigância individual e de itens já constantes na política de saúde pública, maior probabilidade de deferimento das demandas e alto índice de pedidos de leitos de UTI. Quanto às estratégias estudadas, revelam-se eficazes no sentido de qualificar o judiciário para tomada de decisões mais condizentes com a política de saúde pública, bem como o sucesso da resolução extrajudicial das demandas, fazendo-se necessário, contudo o reforço de recursos humanos em ambas as iniciativas, que estão em fase de expansão.

Palavras-chave: Direito à saúde. Políticas públicas. Judicialização da saúde. Fundamentação. DiálogoInstitucional. Desjudicialização. 


\begin{abstract}
The judicialization of health has become institutionalized and is now one more form of access to the Unified Health System (SUS). However, the implementation of fundamental rights cannot be given priority in this way. The understanding of the double nature of the right to health strengthens the understanding of its objective character, which expends objective duties to the Public Power, and efforts should be concentrated on improving its voluntary service, focusing on the necessary procedures and organizational structures. They are ways to implement the right to health by rationalizing and reducing its judicialization, respectively, creating more formal decision-making parameters and deepening the process of interaction among the agents of the legal, administrative and health system through institutional dialogue mechanisms. With a view to further deepening the mobilization measures by disjudicialization, considering the perspective of the various actors involved, the present research turns to the study of the judicial and extrajudicial strategies used to contain the excessive judicialization of health, with emphasis on the experiences developed in the State of Ceará, sustaining the disjudicialization as an alternative to judicial activism. Based on these considerations, the general objective of the present study is to analyze the panorama of the judicialization of health in the State of Ceará and to understand how the establishment of measures of disjudicialization can provide satisfactory solutions to this problem, contributing to a more public health policy effective and easily accessible. For this, a methodological strategy was developed using quantitative and qualitative techniques of production, data collection and analysis. The research was exploratory and developed based on the jurisprudential analysis in the scope of the Court of Justice of the State of Ceará, with the purpose of constructing a profile of public health litigation, seeking to categorize them through variables such as: author, defendant, health defendant, existence of the anticipation of guardianship, argumentation of the judicial decision, collective and individual actions. In addition to collecting these data, the study also aimed to analyze the judicial health policy and some experiences of the realization of the right to health in the State of Ceará regarding the institutional arrangements developed for the expansion of the right to health. In addition to the bibliographic research, the Health Department of the State of Ceará (SESA), the Health Defense Center (NUDESA) and the Technical Support Center for the Judiciary (NATJUS-CE) were visited to collect data from the institutions. Tables were used for a better analysis and systematization of the results. Among the results found, the predominance of individual and item litigation in the public health policy is more pronounced in the State of Ceará than in the judiciary, a greater probability of deferral of demands and a high rate of requests for ICU beds. As for the strategies studied, they are effective in qualifying the judiciary to make decisions more in line with the public health policy, as well as the success of the extra-judicial resolution of the demands, making it necessary, however, to strengthen human resources in both initiatives, which are in the expansion phase.
\end{abstract}

Keywords: Right to health. Public policy. Judicialization of health. Rationale. Institutional Dialogue. Disjudicialization. 


\section{LISTA DE TABELAS}

Tabela 1 - Beneficiários de planos privados de saúde por cobertura assistencial (Brasil - 20072017) 60

Tabela 2-Legitimidade das ações segundo os acórdãos demandados em 2017. 113

Tabela 3-Comarca de origem da ação, segundo os acórdãos demandados em 2017 114

Tabela 4 - Tipo de ação, representante jurídico do autor e titularidade segundo os acórdãos demandados em 2017

Tabela 5 - Condição econômico-financeira do autor da ação segundo os acórdãos demandados em 2017

Tabela 6 - Resultados das ações em primeira e segunda instância segundo os acórdãos demandados em 2017 116

Tabela 7 - Deferimento do pedido na sentença e no acórdão segundo as ações demandadas em 2017

Tabela 8 - Distribuição das demandas requeridas segundo os acórdãos demandados em 2017

Tabela 9 - Argumentações de princípios de direito nas decisões judiciais segundo os acórdãos demandados em 2017

Tabela 10 - Argumentações legais nas decisões judiciais segundo os acórdãos demandados em 2017

Tabela 11 - Demandas 2018 145 


\section{SUMÁRIO}

INTRODUÇÃO ........................................................................................................................ 11

1 SERVIÇO PÚBLICO DE SAÚDE: aspectos históricos ................................................. 14

1.1 A política de saúde pública no Brasil ................................................................. 14

1.2 A política de saúde pública no Estado do Ceará ………………………………....... 28

2 DO DIREITO FUNDAMENTAL AO SERVIÇO PÚBLICO DE SAÚDE ADEQUADO

E SUA EXIGIBILDADE ................................................................................................. 40

2.1 Da noção de serviço público adequado ..................................................................... 40

2.2 A dupla dimensão do direito à saúde e sua relevância no campo da exigibilidade dos direitos

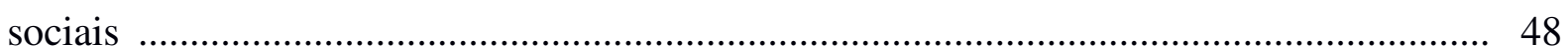

2.3 Os óbices e os avanços na prestação de um serviço de saúde adequado ......................... 59

3 A JUDICIALIZAÇÃO DA SAÚDE PÚBLICA...................................................... 70

3.1 Saúde como direito social prestacional, subjetivo e de aplicabilidade imediata ............. 73

$3.2 \mathrm{O}$ caráter político das políticas públicas em saúde e os limites a intervenção judicial ... 76

3.3 A Teoria da Capacidade Institucional e o ente mais competente para desenvolver políticas públicas em saúde.

3.4 Fundamentos Jurídicos do controle judicial sobre política pública de saúde: aspectos a serem considerados nas decisões judiciais .......................................................................... 87

3.5 A Judicialização da saúde no Estado do Ceará: um esforço pela autocontenção judicial.. 103

4 A JUDICIALIZAÇÃO DA SAÚDE NO ESTADO DO CEARÁ NO ANO DE 2017 E DIÁLOGO INSTITUCIONAL COMO ALTERNATIVA AO EXCESSO DE JUDICIALIZAÇÃO NA SAÚDE PÚBLICA .............................................................. 108

4.1 Diagnóstico da Judicialização em saúde no Tribunal de Justiça do Estado do Ceará - TJCE 109

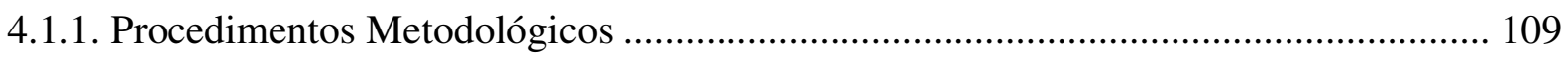

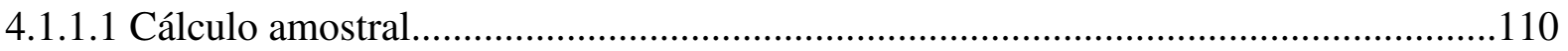

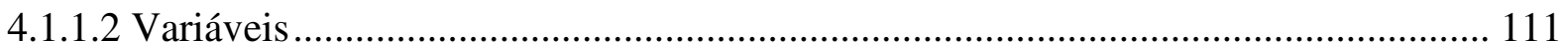

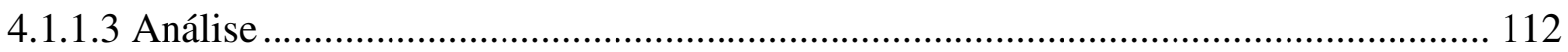

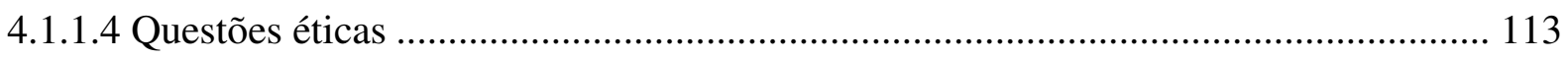

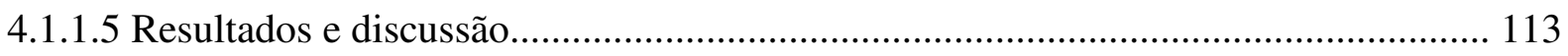

4.2 Desjudicialização da saúde: o Diálogo Institucional como ferramenta de acesso à Justiça 
4.3.1 O Núcleo de Apoio Técnico ao Judiciário (NATJUS) no Estado do Ceará.

4.3.2 O Núcleo de Atendimento Inicial em Saúde (NAIS) no Estado do Ceará...... 141

5 CONSIDERAÇÕES FINAIS. 148

REFERÊNCIAS 151

ANEXO A - Termo de Cooperação Técnica nº 07/2016. 163

ANEXO B - Resolução no 74/2013. .168

ANEXO C - Resolução no 137/2016. .173 


\section{INTRODUÇÃO}

Nos últimos anos, a judicialização da saúde tem se dado de forma massiva, deixando de ser a exceção para se tornar a primeira opção por alguns grupos na busca de adquirir medicamentos e/ou terapias negadas pelo Sistema Único de Saúde (SUS) ou não relacionadas na lista da Relação Nacional de Medicamentos (RENAME).

O ativismo judicial tem levado a uma nova forma de alocação de recursos e serviços na saúde e, buscando sua contenção, vê-se o surgimento de uma política judiciária de desjudicialização desenvolvida por iniciativa do Conselho Nacional de Justiça (CNJ), bem como a criação de arranjos institucionais entre os diversos atores envolvidos na prestação das ações e serviços de saúde pública em vários Estados do país.

Diante desse cenário, o presente estudo justifica-se na tentativa de apresentar um maior aprofundamento das medidas de mobilização pela desjudicialização, possibilitando compreender melhor o atual panorama da judicialização da saúde e da política judiciária de saúde, sobretudo no Estado do Ceará. Assim, torna-se fundamental uma análise precisa da relação entre sociedade, gestão e Poder Judiciário, com foco nas estratégias judiciais e extrajudiciais de efetivação do direito à saúde, sobretudo na dimensão pública.

A presente pesquisa volta-se para o estudo das estratégias judiciais e extrajudiciais utilizadas para conter a excessiva judicialização da saúde, com ênfase nas experiências desenvolvidas no Estado do Ceará, sustentando a desjudicialização como alternativa ao ativismo judicial. Para tanto, esse estudo possui a seguinte problemática: Como funcionam as estratégias judiciais e extrajudiciais desenvolvidas no âmbito do Estado para conter a excessiva judicialização da saúde?

Partindo-se dessas considerações, o objetivo geral desse estudo será de analisar o panorama da judicialização da saúde no Estado do Ceará e compreender como e em que medida o estabelecimento de estratégias de desjudicialização consegue fornecer soluções satisfatórias para tal problema, contribuindo para uma Política de Saúde Pública mais eficaz e facilmente acessível.

Este estudo se funda na necessidade de ampliar o debate sobre a judicialização da saúde na circunscrição do Estado do Ceará, visto a carência de estudos específicos sobre a matéria; sendo escolhido o Tribunal de Justiça do Estado do Ceará (TJCE), pois no seu âmbito houve recentemente a adoção de uma política de desjudicialização resultando, por exemplo, na instalação do NAT-JUS/CE. 
Salienta-se que já se percebe o quanto a realidade nacional dos últimos anos, marcada pelo fenômeno cada vez mais intenso da judicialização da saúde, traz consigo uma gama de questões que demandam soluções específicas. Nesse contexto, este trabalho procura explorar possíveis alternativas aos excessos de judicialização da saúde, no sentido de subsidiar uma estratégia voltada a sua redução, com base na abordagem de Direito e Políticas Públicas.

Para o desenvolvimento do presente estudo foi desenvolvida uma estratégia metodológica que se utilizou de técnicas quantitativas e qualitativas de produção, coleta e análise de dados. A pesquisa foi exploratória e elaborada com base na análise jurisprudencial no âmbito do Tribunal de Justiça do Estado do Ceará, com a finalidade de construir um perfil dos litígios em saúde pública, buscando categorizá-los mediante variáveis como: autor, réu, bem de saúde demandado, existência da antecipação de tutela, argumentação da decisão judicial, ações coletivas e individuais. Além da coleta desses dados, o estudo também teve como foco analisar a política judiciária de saúde e algumas experiências de efetivação do direito à saúde no Estado do Ceará a respeito dos arranjos institucionais desenvolvidos para a ampliação do direito à saúde. Para tanto, além da pesquisa bibliográfica, foram visitados a Secretaria de Saúde do Estado do Ceará (SESA), o Núcleo de Defesa da Saúde (NUDESA) e o Núcleo de Apoio Técnico ao Judiciário (NATJUS-CE), para coleta de dados junto às instituições.

Sendo assim, a pesquisa está dividida em cinco capítulos. O primeiro capítulo consiste em breve retrospecto, a fim de identificar as condições históricas do surgimento e evolução das políticas públicas de saúde no Brasil, o que possibilitará uma melhor compreensão de conceitos importantes sobre o tema. Em seguida, também realiza um estudo de aspectos relacionados à política pública em saúde desenvolvida no âmbito do Estado do Ceará.

No segundo capítulo, sustenta-se o serviço público de saúde adequado como um direito fundamental e considerando o cenário problemático de crescente judicialização de demandas individuais em saúde, pretende-se, por meio da compreensão da natureza dúplice do direito à saúde, fortalecer o entendimento do caráter objetivo do direito, que expende deveres objetivos ao Poder Público, devendo ser concentrados esforços no aprimoramento da sua prestação voluntária, com foco nos seus procedimentos necessários e nas estruturas organizacionais, em detrimento da judicialização indiscriminada. Após apresentar o contexto e perspectivas da saúde no país, expõe-se algumas novidades lançadas pelo legislador em matéria de serviços públicos, frente a sugestões da doutrina de medidas administrativas mais favoráveis à redução efetiva do excesso de demandas na área da saúde.

No terceiro capítulo aborda-se a judicialização do direito fundamental à saúde, considerado como direito social prestacional, subjetivo e de aplicabilidade imediata. Discute- 
se, inicialmente, o caráter eminentemente político das políticas públicas e os limites à intervenção judicial. Traz-se à discussão o diferencial do argumento das capacidades institucionais proposto por Cass Sunstein e Adrian Vermeule, e como esse argumento pode contribuir para uma autocontenção e desjudicialização das políticas de saúde. Serão apresentados fundamentos jurídicos para o controle judicial sobre políticas públicas e os esforços para uma autocontenção judicial no Brasil e no Estado do Ceará.

No quarto capítulo, se analisa o panorama da judicialização da saúde, particularmente no âmbito do Tribunal de Justiça do Estado do Ceará (mediante coleta e análise de dados empíricos provenientes da Jurisprudência de $2^{\circ} \mathrm{Grau}$ ). Apresenta, de maneira sucinta, o instrumental de coleta de dados da pesquisa jurisprudencial e, a posteriori, a sistematização dos resultados, expostos por meio de tabelas, para um melhor entendimento. A partir dos resultados encontrados, se sustenta que o melhor caminho para fortalecer o SUS, e, consequentemente, efetivar o direito à saúde, seria racionalizando o processo de interação entre os agentes do sistema jurídico, administrativo e sanitário, através de mecanismos de diálogo institucional. Investiga-se como funcionam essas medidas de diálogo (arranjos institucionais, como o caso do NAIS) e de reforço da capacidade do Judiciário (criação do NAT'S) e seu potencial para a desjudicialização e autocontenção do Poder Judiciário em matéria de Políticas Públicas de saúde.

No quinto capítulo, serão apresentadas as considerações finais seguidas das sugestões de melhoria para o tema que instigou a presente pesquisa. 


\section{SERVIÇO PÚBLICO DE SAÚDE: aspectos históricos}

A tarefa de definir os contornos do que consiste o direito ao serviço público de saúde adequado impõe a realização de um breve retrospecto, a fim de identificar as condições históricas do surgimento e evolução das políticas públicas de saúde no Brasil e no Estado do Ceará, o que possibilitará uma melhor compreensão de conceitos importantes sobre o tema.

\subsection{A política de saúde pública no Brasil}

A vinda da Corte Portuguesa para o Brasil, em 1808, e a consequente necessidade da organização de uma estrutura sanitária mínima, determinou mudanças na administração pública colonial na área da saúde, capaz de dar suporte ao poder que se instalava na cidade do Rio de Janeiro, principal porto do país. Até 1850, as atividades de saúde pública estavam limitadas a: “i) delegação das atribuições sanitárias às juntas municipais; e ii) controle de navios e saúde dos portos" (CONASS, 2007, p.17).

Esse interesse primordial de manter um controle sanitário mínimo da capital do Império se perpetuou por quase um século e a fase imperial da história brasileira encerrou-se sem que o Estado solucionasse graves problemas de saúde da coletividade. Somente após a Proclamação da República, em 1889, práticas de saúde em nível nacional tiveram início, graças a um ativo movimento de Reforma Sanitária, sob a liderança de uma nova geração de médicos higienistas, como Oswaldo Cruz e Carlos Chagas. Entre as conquistas desse movimento, destaca-se a criação do Departamento Nacional de Saúde Pública (DNSP), em 1920 (CONASS, 2007).

O Estado brasileiro teve sua primeira intervenção em 1923, com a Lei Elói Chaves, que regulamentou a criação das Caixas de Aposentadoria e Pensão (CAPs), que asseguravam aos trabalhadores e empresários, uma série de direitos, como a assistência médica. Sendo considerado esse, o marco inicial da previdência social no Brasil:

As CAPs eram financiadas pela União, pelas empresas empregadoras e pelos empregados. Elas eram organizadas por empresas, de modo que só os grandes estabelecimentos tinham condições de mantê-las. O presidente das mesmas era nomeado pelo presidente da República e os patrões e empregados participavam paritariamente da administração. Os benefícios eram proporcionais às contribuições e foram previstos: assistência médica-curativa e fornecimento de medicamentos; aposentadoria por tempo de serviço, velhice e invalidez, pensão para os dependentes e auxílio funeral. (BRAVO, 2001, p. 3). 
O início da intervenção do Estado no setor se deu mais efetivamente a partir da década de 30. Com a instalação do Estado Novo, em substituição ao sistema extremamente fragmentário das CAPs, foram instituídos os Institutos de Aposentadoria e Pensões (IAPs), congregando o conjunto de trabalhadores de um determinado ofício ou setor de atividade (FINKELMAN, 2002).

Enquanto a assistência médica evoluía de forma segmentada e restrita aos contribuintes urbanos da previdência social, a primeira mudança na cultura campanhista ${ }^{1}$ de atuação verticalizada do governo federal no âmbito da saúde pública, se deu com a criação, em 1942, do Serviço Especial de Saúde Pública (SESP). Referido serviço, fruto de um acordo entre os governos do Brasil e dos Estados Unidos, objetivava proporcionar apoio médico-sanitário às regiões de produção de materiais estratégicos que representavam, na época, uma contribuição do Brasil ao esforço de guerra das democracias no desenrolar da $2^{\mathrm{a}}$ Guerra Mundial, por esse motivo, seu espaço geográfico inicial de atuação limitou-se à Amazônia (produção de borracha), ao Estado de Goiás e ao Vale do Rio Doce (minérios) (FINKELMAN, 2002).

Considerando que, no Brasil, a saúde nem sempre foi considerada um direito social universal $^{2}$, a maior inovação na assistência à saúde, teria se dado em 1949, durante o segundo governo Vargas, quando foi criado o Serviço de Assistência Médica Domiciliar de Urgência (SAMDU):

\begin{abstract}
A importância histórica desse evento decorre de três características inovadoras da iniciativa: o atendimento médico domiciliar até então inexistente no setor público, embora comum na prática privada; o financiamento consorciado entre todos os IAPs e, principalmente, o atendimento universal ainda que limitado aos casos de urgência (FINKELMAN, 2002, p. 237).
\end{abstract}

Ressalte-se que a estrutura de atendimento hospitalar de natureza privada, com fins lucrativos, já estava montada a partir dos anos 50, apontando na direção da formação das empresas médicas. Naquele momento, a corporação médica ligada aos interesses capitalistas do setor era a mais organizada e pressionava o financiamento, através do Estado, da produção

\footnotetext{
${ }^{1}$ No início do século XX, campanhas realizadas sob moldes quase militares implementaram atividades de saúde pública. (in PAIM et al. O Sistema de Saúde brasileiro: histórias, avanços e desafios. p. 14, Disponível em: <https://www.passeidireto.com/arquivo/6082122/2-o-sistema-de-saude-brasileiro---historia-avancos-e-desafios>. Acesso em: 10 jan 2018).

${ }^{2}$ Impende ressaltar que: "Em que pese o crescimento gradual do número de categorias profissionais e do elenco de benefícios em quatro de(sic) décadas, a previdência social, na primeira metade dos anos 60 , ainda estava longe da universalização. Em 1960, no final do período desenvolvimentista de Kubitschek, os segurados da previdência somavam pouco mais de 5 milhões (dos quais 4 milhões eram contribuintes ativos e o restante composto por aposentados e pensionistas), ou seja, apenas 7,3\% de uma população da ordem de 70 milhões.”(in FINKELMAN, Jacobo (Org.) Caminhos da saúde pública no Brasil. Rio de Janeiro: Editora FIOCRUZ, 2002, p. 239).
} 
privada, defendendo claramente a privatização. Todavia, apesar das pressões, a assistência médica previdenciária, até 1964, era fornecida basicamente pelos serviços próprios dos institutos. As formas de compra dos serviços médicos a terceiros aparecem como minoritárias e pouco expressivas no quadro geral da prestação da assistência médica pelos institutos (BRAVO, 2001).

O governo militar implantou reformas institucionais que afetaram profundamente a saúde pública e a medicina previdenciária. Com a unificação dos Institutos de Aposentadoria e Pensões (IAPs) no Instituto Nacional de Previdência Social (INPS), em 1966, todas as contribuições previdenciárias foram concentradas, e ao mesmo tempo, o novo órgão passou a gerir as aposentadorias, as pensões e a assistência médica de todos os trabalhadores formais, embora ainda estivessem excluídos dos benefícios os trabalhadores rurais e uma gama de trabalhadores urbanos informais (CONASS, 2007).

Durante o regime, a expansão de um sistema de saúde predominantemente privado, principalmente nos grandes centros urbanos, passou a ser impulsionada pelas reformas governamentais. Seguiu-se uma rápida ampliação da cobertura, que estendeu a previdência social aos trabalhadores rurais (PAIM et al., 2011).

Através da promulgação do Decreto Lei no 200, em 25 de fevereiro de 1967, ficou estabelecido ser de competência do Ministério da Saúde: a formulação e coordenação da política nacional de saúde; a responsabilidade pelas atividades médicas ambulatoriais e ações preventivas em geral; o controle de drogas e medicamentos e alimentos e as pesquisas médicosanitárias.

Na década de 1970, a assistência médica financiada pela Previdência Social teve seu período de maior expansão em número de leitos disponíveis, em cobertura e em volume de recursos arrecadados, além de dispor do maior orçamento de sua história. Contudo, os serviços médicos prestados pelas empresas privadas aos previdenciários eram pagos por Unidade de Serviço $(\mathrm{US})^{3}$, forma de pagamento que se tornou uma fonte incontrolável de corrupção (CONASS, 2007).

\footnotetext{
${ }^{3}$ Nessa forma de pagamento aos prestadores privados, cada elemento do procedimento ou da intervenção dos médicos era contado separadamente, assim como ainda hoje ocorre com os planos privados de saúde, quanto ao tema: "Essa forma de pagamento gera superprodução de procedimentos, já que os ganhos dos profissionais, clínicas e hospitais é tanto maior quanto mais procedimentos usam ou indicam. A consequência é o alto custo dos serviços e a baixa capacidade de controle (com a possibilidade de muitas fraudes, como de fato ocorreu na época). Isso compromete os serviços, já que são valorizados os procedimentos cujas unidades de serviço são mais bem pagas. Essa lógica também desvaloriza a prevenção e a promoção em saúde e estimula a população a pensar o atendimento médico como sinônimo de exames e intervenções, o que pode comprometer sua própria saúde. Ainda sob a vigência do Inamps, a unidade de serviços foi substituída pela Autorização de Internação Hospitalar (AIH). Ainda hoje utilizada para o pagamento de internações, fixa um valor para cada grupo de diagnósticos, prevendo já um conjunto de procedimentos a ele relacionados." (CIOVANELLA, Lígia (org.) Políticas e Sistema de Saúde no
} 
Por volta de 1975, o modelo econômico implantado pela ditadura militar entrou em crise:

A população com baixos salários, contidos pela política econômica e pela repressão, passou a conviver com o desemprego e as suas graves consequências sociais, como aumento da marginalidade, das favelas, da mortalidade infantil. O modelo de saúde previdenciário começa a mostrar as suas mazelas (CONASS, 2007, p.24).

Ainda em 1975, através da Lei nº 6.229, o Governo Federal instituiu o Sistema Nacional de Saúde (SNS), 'complexo de serviços do setor público e do setor privado, voltados para as ações de interesse da saúde [...] abrangendo atividades que visem à promoção, proteção e recuperação da saúde'. O documento dispõe sobre a organização do Sistema Nacional de Saúde (SNS), definindo dois grandes campos institucionais: a atuação voltada para o atendimento médico-assistencial individualizado seria de competência do Ministério da Previdência; e a ação voltada para medidas e atendimentos de interesse coletivo, inclusive vigilância sanitária, de responsabilidade do Ministério da Saúde (FINKELMAN, 2002).

Tendo como referência as recomendações internacionais ${ }^{4}$ e a necessidade de expandir cobertura, em 1976 inicia-se o Programa de Interiorização das Ações de Saúde e Saneamento (PIASS), aprovado pelo Decreto $\mathrm{n}^{\mathrm{o}} \mathbf{7 6 . 3 0 7}$, de 24/8/1976, que se configura como o primeiro programa de medicina simplificada, do nível federal, e vai permitir a entrada de técnicos provenientes do movimento sanitário no interior do aparelho de estado:

\begin{abstract}
O objeto central do Programa era dotar as comunidades do Nordeste - cidades, vilas e povoados até 20 mil habitantes - de uma estrutura básica e permanente de saúde pública capaz de contribuir na solução dos problemas médico-sanitários de maior reflexo social. A rede de serviços, fundamentalmente estadual e municipal, se desdobrava em três níveis de atuação: elementar, intermediário e de apoio. Os dois primeiros estavam constituídos por unidades operadas por pessoal de nível elementar. As unidades de apoio, estrategicamente localizadas, estavam formadas por unidades integradas de saúde, dispondo de recursos humanos de nível profissional e, em alguns casos, de facilidades para hospitalização (FINKELMAN, 2002, p.244).
\end{abstract}

Em 1977, através da Lei $n^{\circ}$ 6.439, foi criado o Sistema Nacional de Assistência e Previdência Social (SINPAS), como mecanismo de articulação entre saúde, previdência e

\footnotetext{
Brasil. 2. ed. rev. e amp. / organizado por Lígia Ciovanella, Sarah Escorei, Lenaura de Vasconcelos Costa Lobato et al. -Rio de Janeiro: Editora Fiocruz, 2012, p.110).

${ }^{4}$ Finkelman esclarece que: "Na assembléia da Organização Mundial de Saúde (OMS) realizada em 1975, Halfdan Mahler, seu diretor geral, afirmou: 'para vencer a dramática falta de médicos no mundo inteiro é indispensável aproveitar todo o pessoal disponível, as parteiras curiosas, o pessoal de nível elementar e até mesmo os curandeiros'. O pronunciamento da OMS vinha ao encontro do que, na época, era consensual e corrente entre parte significativa de formadores de opinião nacionais no setor saúde: a única possibilidade de levar a assistência médico-sanitária a todos dos que dela carecem é através da utilização de técnicas simples e de baixo custo, aplicáveis sem dificuldade ou risco, por pessoal de nível elementar recrutado na própria comunidade e remunerado de acordo com os padrões locais." (In FINKELMAN, Jacobo (Org.) Caminhos da saúde pública no Brasil. Rio de Janeiro: Editora FIOCRUZ, 2002, p.244).
} 
assistência no âmbito do Ministério de Previdência e Assistência Social (MPAS). Vinculado a ele estaria o Instituto Nacional de Assistência Médica da Previdência Social (INAMPS), que passou a ser o órgão coordenador de todas as ações de saúde no nível médico-assistencial da previdência social (GIOVANELLA, 2012).

A assistência pública em saúde no Brasil consistia basicamente na oferta de serviços em grandes hospitais privados com super especialistas, contratados pelo Instituto Nacional de Assistência Médica da Previdência Social (INAMPS), que atendiam apenas trabalhadores formais que pagavam impostos, enquanto grande parte da população brasileira ficava descoberta. Tal modelo assistencial-privativa de saúde, de caráter nitidamente contributivo, em vigor no Brasil, por força do art. 158, inciso XV, da Constituição da República de 1967, era marcado "pela insuficiência de recursos, pela disputa de comando entre o INAMPS e o Ministério da Saúde, pela restrição de acesso e pela oferta de tratamentos especializados segundo a lógica de mercado" (MAPELLY JUNIOR, 2017, p. 1).

Ainda na década de 70 surgiu o Movimento da Reforma Sanitária, e o tema saúde deixou de ser de interesse apenas dos técnicos para assumir uma dimensão política, estando estreitamente vinculado à democracia. Novos sujeitos sociais, como entidades representantes de profissionais de saúde, o Centro Brasileiro de Estudo de Saúde (CEBES) e partidos políticos de oposição, entraram na discussão das condições de vida da população brasileira e das propostas governamentais apresentadas para o setor, contribuindo para um amplo debate que permeou a sociedade civil (BRAVO, 2001, p.8). Dentre as principais propostas debatidas por esses sujeitos coletivos situavam-se:

[...] a universalização do acesso; a concepção de saúde ${ }^{5}$ como direito social e dever do Estado; a reestruturação do setor através da estratégia do Sistema Unificado de Saúde visando um profundo reordenamento setorial com um novo olhar sobre a saúde individual e coletiva; a descentralização do processo decisório para as esferas estadual e municipal, o financiamento efetivo e a democratização do poder local através de novos mecanismos de gestão - os Conselhos de Saúde (BRAVO, 2001, p.9).

Nesse momento de crise, o setor médico privado, que havia se beneficiado do modelo médico-privativista durante quinze anos a partir de 64, tendo recebido, neste período, vultosos recursos do setor público e financiamentos subsidiados, percebendo que não mais poderia se manter e se nutrir do setor público, passou a formular novas alternativas para sua estruturação.

\footnotetext{
${ }^{5} \mathrm{~A}$ saúde garantida como direito social no texto constitucional é concebida de forma ampliada, reconhecendo não só a perspectiva de pretensão a um corpo sem doenças, mas incluindo também a determinação social sobre o processo saúde-doença. Nesse sentido, o teor do Artigo $2^{\circ}, \S 3^{\circ}$ da Lei $n^{\circ} 8.080 / 90$, que vale transcrever: "A saúde tem como fatores determinantes e condicionantes, entre outros, a alimentação, a moradia, o saneamento básico, $\mathrm{o}$ meio ambiente, o trabalho, a renda, a educação, o transporte, o lazer e o acesso aos bens e serviços essenciais; os níveis de saúde da população expressam a organização social e econômica do País” (BRASIL, 1990).
} 
Concebeu-se então um subsistema de atenção médico-supletiva composta de cinco modalidades assistenciais: medicina de grupo, cooperativas médicas, auto-gestão, seguro-saúde e plano de administração. Referidas modalidades se baseavam em contribuições mensais dos beneficiários (poupança) em contrapartida pela prestação de determinados serviços. Tais serviços e benefícios "eram pré-determinados, com prazos de carências, além de determinadas exclusões, por exemplo, a não cobertura do tratamento de doenças infecciosas".

As modificações da década de 1980 culminaram com a promulgação da Constituição de 1988, que inaugurou um novo sistema de proteção social pautado na concepção de Seguridade Social, que universalizou os direitos sociais, concebendo a saúde ${ }^{6}$ como questão pública de responsabilidade do Estado:

A Constitucionalização da saúde, na Constituição Federal de 1988, como proposto pelos idealizadores do movimento sanitarista brasileiro, como direito social $\left(\operatorname{art} .6^{\circ}\right) \mathrm{e}$ dever do Estado, que deve ser garantido por meio de 'políticas sociais e econômicas que visem a redução de doenças e outros agravos e ao acesso universal e igualitário às ações e serviços para sua promoção, proteção e recuperação'(art.196), modificou então a concepção jurídica de saúde, trazendo para o plano do direito a responsabilidade solidária entre os entes da federação (art.23, II) na construção de políticas públicas que promovam o atendimento integral das necessidades da população, a atenção básica a procedimentos de maior complexidade (art.198, caput, II), para todos os residentes no Brasil (MAPELLY JUNIOR, 2017,p. 2).

Com a criação do SUS (art.198), a Constituição de 1988 rompe com o antigo modelo de saúde que era dominado pelo sistema previdenciário. A implementação do SUS começou em 1990, mesmo ano da posse de Fernando Collor de Mello, o primeiro presidente eleito por voto popular desde a ditadura militar, que seguiu uma agenda neoliberal e não se comprometeu com a reforma sanitária. Ainda assim, em 1990, foi aprovada a Lei Orgânica da Saúde (Lei nº 8.080/90), que especificava as atribuições e a organização do SUS (PAIM et al, 2011).

De acordo com a Lei Orgânica da Saúde, o SUS é constituído pelo conjunto de ações e serviços de saúde, prestados por órgãos e instituições públicas federais, estaduais e municipais, da Administração direta e indireta e das fundações mantidas pelo Poder Público ( $\operatorname{art} .4^{\circ}$ ). Os principais princípios do SUS, estabelecidos por sua Lei Orgânica ( $\left.\operatorname{art} .7^{\circ}\right)$, são: a universalidade de acesso em todos os níveis de assistência; a integralidade; a igualdade, sem preconceitos ou

\footnotetext{
${ }^{6}$ Decorrente do constitucionalismo do começo do século XX, construído à luz das críticas dos movimentos socialistas que os antecederam, a ideologia consagrada em nossa Constituição formata a saúde pública ou coletiva como direito fundamental integrante da cidadania $\left(\operatorname{art} .6^{\circ}, \mathrm{CF}\right)$. O direito à saúde passa a ser compreendido como bem-estar biopsicossocial amplo, conforme o proposto pela Organização Mundial de Saúde, não estando restrito à mera cura ou tratamento de doenças (Preâmbulo da Constituição da OMS, 07 de abril de 1948), a ser garantido por políticas públicas de Estado, que devem enfatizar os cuidados primários da população, nos termos da declaração de Alma-Ata. (MAPELLI JÚNIOR, Reynaldo. Judicialização da saúde: regime jurídico do SUS e intervenção na Administração pública. 1.ed. - Rio de Janeiro: Atheneu, 2017, p.2).
} 
privilégios de qualquer espécie; a participação da comunidade; e a descentralização políticoadministrativa:

\begin{abstract}
a) universalidade, que se consubstancia no direito de qualquer indivíduo, independentemente de duas condições pessoais (nacionalidade, naturalidade, classe social, etc.) de ser atendido pelos órgãos de saúde pública, ser beneficiado pelas ações que programam políticas públicas direcionadas à saúde da população e de ter à sua disposição todos os medicamentos e insumos indispensáveis para prevenção e proteção de sua saúde; b) integralidade, princípio segundo o qual deverão ser destinados àqueles de que necessitem toda a assistência necessária para a recuperação da doença e sua prevenção, assim como políticas sociais e econômicas que visem à redução do risco de doença e de outros agravos; c) igualdade, segundo o qual a todos aqueles que necessitem de atendimento deve o Estado dispensar tratamento equânime, sem discriminações de qualquer natureza e sem oferecer privilégios ou preferências de origem subjetiva, devendo as ações e serviços de saúde ser(sic)distribuídos de maneira igualitária pelo gestor; [...] f) descentralização, significando que as ações e serviços devem ser passados à responsabilidade dos municípios, permanecendo os poderes públicos estatal e federal como corresponsáveis; g) participação social, consistente na participação da comunidade em Conferências de Saúde e Conselhos de Saúde [...] (MAPELLY JÚNIOR,2017,p. 12) grifo nosso.
\end{abstract}

Impende ressaltar que o princípio da descentralização está relacionado, também, ao esforço pela regionalização e hierarquização, consistente na necessidade de organizar a prestação dos serviços por meio de divisões territoriais, bem como a divisão da prestação do serviço em classes, de acordo com a complexidade, no sentido de uma série contínua de graus (do menos complexo ao mais complexo) (MAPELLY JUNIOR, 2017).

A Lei Orgânica da Saúde foi complementada pela Lei no 8.142/90, que regula a participação da comunidade no SUS, e assegurou a existência de instâncias colegiadas como conferências $^{7} \mathrm{e}$ conselhos de saúde ${ }^{8}$ nos três níveis de governo, além de orientar as transferências intergovernamentais de recursos financeiros da área de saúde e de exigir a formulação de planos de saúde e a criação de fundos de saúde (PAIM, 2008).

Após o impeachment do presidente, em 1992, o projeto da reforma sanitária foi retomado. A descentralização aumentou e foi lançado o Programa de Saúde da Família (PSF). Um novo plano de estabilização econômica (Plano Real) foi introduzido em 1994, trazendo políticas de ajuste macroeconômico e projetos de reforma do Estado. Com a eleição de

\footnotetext{
${ }^{7} \mathrm{Na}$ Lei $\mathrm{n}^{\circ} 8.142 / 90$, ficou estabelecido que a Conferência Nacional de Saúde - CNS fosse realizada a cada quatro anos, "com a representação dos vários segmentos sociais, para avaliar a situação de saúde e propor diretrizes para a formulação de políticas de saúde nos níveis correspondentes, convocadas pelo Poder Executivo ou, extraordinariamente, por este ou pelo Conselho de Saúde".

${ }^{8} \mathrm{O}$ artigo $1^{\circ}$ da Lei $\mathrm{n}^{\circ}$ 8.142/90 em seu parágrafo segundo define: "O Conselho de Saúde, em caráter permanente e deliberativo, órgão colegiado composto por representantes do governo, prestadores de serviço, profissionais de saúde e usuários, atua na formulação de estratégias e no controle da execução da política de saúde na instância correspondente, inclusive nos aspectos econômicos e financeiros, cujas decisões serão homologadas pelo chefe do poder legalmente constituído em cada esfera de governo".
} 
Fernando Henrique Cardoso (reeleito em 1998), foram realizados novos processos de ajuste macroeconômico e de privatização (PAIM et al., 2011).

Diante do redirecionamento do papel do Estado, nos anos 90, influenciado pela Política de Ajuste Neoliberal, a proposta de Política de Saúde construída na década de 1980 viu-se desconstruída:

\begin{abstract}
A Saúde fica vinculada ao mercado, enfatizando-se as parcerias com a sociedade civil, responsabilizando a mesma para assumir os custos da crise. A refilantropização é uma de suas manifestações com a utilização de agentes comunitários e cuidadores para realizarem atividades profissionais, com o objetivo de reduzir os custos. Com relação ao Sistema Único de Saúde (SUS), apesar das declarações oficiais de adesão ao mesmo, verificou-se o descumprimento dos dispositivos constitucionais e legais e uma omissão do governo federal na regulamentação e fiscalização das ações de saúde em geral. Algumas questões comprometeram a possibilidade de avanço do SUS como política social, cabendo destacar: o desrespeito ao princípio da eqüidade na alocação dos recursos públicos pela não unificação dos orçamentos federal, estaduais e municipais; afastamento do princípio da integralidade, ou seja, indissolubilidade entre prevenção e atenção curativa havendo prioridade para a assistência médico-hospitalar em detrimento das ações de promoção e proteção da saúde. A proposta de Reforma do Estado para o setor saúde ou contra-reforma propunha separar o SUS em dois: o hospitalar e o básico. Outro aspecto a ser considerado refere-se à remuneração por produção, denunciada há vinte anos como "fator incontrolável de corrupção". Constata-se que além de gastar mal também se gasta pouco em saúde, comparado com os parâmetros internacionais (BRAVO, 2001, p. 13).
\end{abstract}

Nesse contexto, dois projetos passaram a conviver em tensão: o projeto de reforma sanitária, construído na década de 1980 e inscrito na Constituição Brasileira de 1988, e o projeto de saúde articulada ao mercado ou privatista, hegemônico na segunda metade da década de 1990. A universalidade do direito (consistente num dos fundamentos centrais do SUS e presente no projeto de Reforma Sanitária) provocou resistência dos formuladores do projeto saúde voltada para o mercado, que tem como premissa concepções individualistas e fragmentadoras da realidade, em contraposição às concepções coletivas e universais do projeto contrahegemônico (BRAVO, 2001).

Luiz Inácio Lula da Silva (eleito em 2002 e reeleito em 2006) manteve alguns aspectos da política econômica de seu antecessor, suspendendo, entretanto, as privatizações e, no seu segundo mandato, promoveu um programa desenvolvimentista. Apesar de a reforma sanitária ter constituído uma prioridade política secundária durante a década de 1990, dentre as várias iniciativas lançadas na área destacam-se: “o programa nacional de controle e prevenção de HIV/AIDS, a criação da Agência Nacional de Vigilância Sanitária, o estabelecimento da Agência Nacional de Saúde Suplementar e a criação de um modelo de atenção à saúde indígena" (PAIM et al, 2011, p.19). Dentre as inúmeras iniciativas implementadas após 2003, durante o 
governo Lula, situam-se o Serviço de Atendimento Móvel de Urgência (SAMU) e a Política Nacional de Saúde Bucal (Brasil Sorridente).

As forças políticas e sociais que passaram a ocupar espaços durante o primeiro mandato do ex-presidente Lula possibilitaram, ainda que no plano discursivo, uma retomada do tema da Reforma Sanitária na agenda política. A expressão Reforma Sanitária, que esteve ausente nos relatórios finais da $9^{\mathrm{a}}, 10^{\mathrm{a}}$ e $11^{\mathrm{a}}$ Conferências Nacionais de Saúde só voltou a ser citada, exatamente, no Relatório Final da $12^{\text {a }}$ Conferência Nacional de Saúde (CNS), em 2003. No âmbito da sociedade civil, a criação do Fórum da Reforma Sanitária Brasileira possibilitou a realização de um conjunto de reuniões com lideranças e militantes do movimento sanitário no período de 2005 a 2006, produzindo textos de natureza técnica e sócio-político-institucional (PAIM, 2008). No âmbito governamental, o processo de re-politização da saúde encontrou ressonância em pelo menos três iniciativas no último ano de seu governo:

\footnotetext{
a) aprovação pela Comissão Intergestores Tripartite (CIT) e pelo Conselho Nacional de Saúde do Pacto pela Saúde, incluindo o Pacto pela Vida, o Pacto em Defesa do SUS e o Pacto de Gestão; b) formalização da Política Nacional de Promoção da Saúde; c) criação da Comissão Nacional de Determinantes Sociais da Saúde (CNDSS) (PAIM, 2008, p.262).
}

Na fase inicial de implantação do SUS, o foco foi a descentralização das ações e serviços de saúde, com forte orientação municipalizante. A regionalização e a formação de redes de atenção despontam como preocupações significativas a partir dos anos 2000, simultaneamente às tentativas de resgatar o papel dos estados, fundamental para avançar efetivamente no processo de regionalização. Diversas normas expressam esse esforço, como a Norma Operacional da Assistência à Saúde/2000; o Pacto pela Saúde/2006; e o Decreto nº 7.508/2011 (IPEA, 2013).

O SUS consolidou-se, ao longo de duas décadas, como a maior política de Estado do País, promotor de inclusão e justiça social, tendo o dever de ofertar, a todos os brasileiros, um conjunto de serviços sanitária e socialmente necessários, com base em protocolos clínicos e diretrizes terapêuticas e por meio de amplo movimento de discussão que envolva os gestores de saúde na Comissão Intergestores Tripartite e o Conselho Nacional de Saúde (CONASS, 2011).

Conforme relatório do Conselho Nacional de Secretários de Saúde (CONASS), elaborado em 2011, os resultados obtidos pelo SUS ao longo de 20 anos já demonstravam o potencial desse sistema de saúde, a ponto de o país passar a ser reconhecido internacionalmente como uma referência no setor da saúde. Seguem algumas das iniciativas bem-sucedidas pelo modelo de saúde brasileiro: 
[...] » O Brasil eliminou o sarampo, em 2007; interrompeu a transmissão da cólera, em 2005, da rubéola, em 2009, e a transmissão vetorial de Chagas, em 2006.

» Foram reduzidas as mortes de outras 11 doenças transmissíveis, como tuberculose, hanseníase, malária e Aids.

»O Serviço de Atendimento Móvel de Urgência (SAMU) atende 105 milhões de brasileiros e oferece uma resposta rápida à população.

» As políticas brasileiras de saúde também reforçam a luta contra o tabaco e nos últimos anos reduziram o percentual de fumantes no país $15 \%$.

» O SUS consolidou-se como o principal fornecedor de medicamentos e o mercado de genéricos está crescendo com o aumento de novos registros de medicamentos.

»O Sistema Nacional de Transplantes é hoje respeitado pela sociedade brasileira, pelos pacientes e pela comunidade transplantadora. Graças a esse trabalho, o Brasil figura hoje no segundo lugar em número absoluto de transplantes realizados ao ano em todo o mundo. Foram realizados, em 2009, 20.200 transplantes, sendo mais de $90 \%$ pelo SUS.[...]

»O Brasil é reconhecido internacionalmente como um país que tem um dos mais completos e bem-sucedidos programas de imunizações do mundo, constituindo-se em poderosa ferramenta de controle de doenças transmissíveis imunopreveníveis. O País consegue garantir altos índices de cobertura vacinal, atingindo de forma estável e universal todos os segmentos populacionais. Esses objetivos vêm sendo obtidos pelo trabalho intenso e contínuo das três esferas de gestão do SUS, que incorporaram entre suas prioridades o Programa Nacional de Imunizações, realizado por meio de campanhas nacionais e rotineiramente nas 30.280 salas de vacina do País (CONASS, 2011, p. 28).

Dentre as ações implementadas a partir do governo Dilma Rousseff (eleita em 2011 e reeleita em 2014) pode-se destacar: o programa Academia da Saúde (Portaria n 719/2011), a Rede Cegonha (Portaria $\mathrm{n}^{\circ}$ 1.459/2011), a Rede de Atenção às Urgências (Portaria $\mathrm{n}^{\circ}$ 1.600/2011), a Rede de Atenção Psicossocial (Portaria $n^{0} 3.088 / 11$, a criação da Comissão Nacional de Incorporação de Tecnologias (CONITEC) ${ }^{9}$ (Lei $\mathrm{n}^{0}$ 12.401/11), a definição da periodicidade de atualização da Relação Nacional de Medicamentos Essenciais (RENAME) (Decreto $\mathrm{n}^{\circ}$ 7.508/11), atualização das normas operacionais do Programa Farmácia Popular do Brasil (PFPB) (Portaria n ${ }^{\circ}$ 971, de 15 de maio de 2012, IPEA, 2013).

Outros esforços implementados no referido governo, encerrado com o impeachment presidencial, em 31 de agosto 2016, foram o lançamento da segunda edição do Programa de Aceleração do Crescimento (PAC 2) na área da saúde, prevendo a construção e reforma das unidades básicas de saúde (USB), unidades de pronto-atendimento (UPA) e a Criação do Programa Mais Médicos (Medida Provisória $n^{\circ}$ 621/2013, regulamentada pela Lei $n^{\circ}$ 12.871/2013) visando a melhoria do atendimento aos usuários do Sistema Único de Saúde (SUS), através do envio de médicos para regiões onde há escassez ou ausência desses profissionais.

\footnotetext{
${ }^{9}$ Essa comissão define critérios objetivos para a incorporação de medicamentos.
} 
A leitura do artigo 197 da Constituição Federal de 1988 revela que o sistema de saúde brasileiro foi instituído de forma composta, uma vez que os serviços podem ser prestados por iniciativa do sistema público, através do Sistema Único de Saúde (SUS), como também pela iniciativa privada ${ }^{10}$, quanto ao tema:

\begin{abstract}
O sistema de saúde brasileiro é formado por uma rede complexa de prestadores e compradores de serviços que competem entre si, gerando uma combinação público privada (sic) financiada sobretudo por recursos privados. O sistema de saúde tem três subsetores: o subsetor público, no qual os serviços são financiados e providos pelo Estado nos níveis federal, estadual e municipal, incluindo os serviços de saúde militares; o subsetor privado (com fins lucrativos ou não), no qual os serviços são financiados de diversas maneiras com recursos públicos ou privados; e, por último, o subsetor de saúde suplementar, com diferentes tipos de planos privados de saúde e de apólices de seguro, além de subsídios fiscais. Os componentes público e privado do sistema são distintos, mas estão interconectados, e as pessoas podem utilizar os serviços de todos os três subsetores, dependendo da facilidade de acesso ou de sua capacidade de pagamento (PAIM et al, 2011, p.19).
\end{abstract}

Historicamente, as políticas de saúde estimularam o setor privado no Brasil e promoveram a privatização da atenção à saúde, através: do credenciamento de consultórios médicos, da remuneração e criação de clínicas diagnósticas e terapêuticas especializadas, hospitais, ou ainda dos incentivos às empresas de planos e seguros de saúde. O subsistema privado de saúde se imbrica com o setor público oferecendo: "serviços terceirizados pelo SUS, serviços hospitalares e ambulatoriais pagos por desembolso direto, medicamentos e planos e seguros de saúde privados", sendo que, parte dessa oferta é financiada pelo SUS e o restante, por fontes privadas (PAIM et al., 2011, p.19).

A rede que compõe o SUS é bem abrangente e constitui-se tanto de ações, como de serviços de saúde. Referido sistema tem como funções "realizar ações de promoção de saúde, controle de vetores e educação sanitária, além de assegurar a continuidade do cuidado nos níveis primário, ambulatorial especializado e hospitalar" (PAIM et al., 2011, p. 20).

Visando facilitar a organização e disponibilização do arcabouço normativo da saúde, o projeto SUS Legis ${ }^{11}$ sistematizou as normas em vigor do Sistema Único de Saúde (SUS), consolidando as portarias sobre a estrutura do SUS (de acordo com a Lei Complementar $\mathrm{n}^{\circ}$ 95/1998). As portarias se dividem em: Portaria de Consolidação $n^{0} 1$ : compreende portarias relativas aos direitos e deveres dos usuários da saúde, organização e funcionamento do SUS;

\footnotetext{
${ }^{10}$ A lei Orgânica da Saúde (Lei n. 8.080/90), em seu art. $7^{\circ}$, dispõe que tanto as ações e serviços públicos de saúde executados diretamente pelo poder público, como aqueles executados por meio de terceiros (serviços contratados ou conveniados), serão desenvolvidos de acordo com as diretrizes e os princípios da Constituição.

${ }^{11}$ O projeto consiste numa iniciativa fruto da parceria entre o Programa de Direito Sanitário da Fiocruz (Prodisa), a Faculdade de Direito da Universidade de Brasília (UnB), o Ministério da Saúde, o CONASS e o Conasems.
} 
Portaria de Consolidação $n^{0}$ 2: políticas nacionais de saúde do SUS; Portaria de Consolidação $\mathrm{n}^{0}$ 3: redes do SUS; Portaria de Consolidação $\mathrm{n}^{\circ}$ 4: sistemas e subsistemas do SUS; Portaria de Consolidação $\mathrm{n}^{\mathrm{o}}$ 5: ações e serviços de saúde do SUS; e Portaria de Consolidação $\mathrm{n}^{\circ}$ 6: financiamento e transferência dos recursos federais para as ações e os serviços de saúde do SUS (CONASS, 2017).

Dentre as mais de quarenta políticas previstas na Portaria de Consolidação $\mathrm{n}^{\circ} 2$, de 28 de setembro de 2017, situam-se: a) políticas gerais de promoção, proteção e recuperação da saúde; b) políticas de controle de doenças e enfrentamento de agravos de saúde; c) políticas voltadas à saúde de segmentos populacionais; c) políticas de promoção da equidade em saúde; d) políticas gerais de organização da atenção à saúde; e) políticas de atenção a agravos específicos, e f) políticas de organização do Sistema Único de Saúde (SUS).

A partir de um contato inicial, constata-se que evolução histórica das políticas de saúde no Brasil, está diretamente relacionada à evolução político-social e econômica da sociedade brasileira e a falta de clareza e definição em relação à política de saúde fez com que a história da saúde pública tenha se confundido com a história da previdência social, em determinados períodos, havendo, contudo, uma tendência daquela figurar como prioridade secundária do governo.

Outra observação é de que somente após quarenta anos da previsão do direto à saúde ter sido consagrado na Declaração Universal dos Direitos Humanos ${ }^{12}$, a Constituição Federal de 1988 o conferiu status de direito constitucional de todos e dever do Estado (art.196), a universalização da saúde no Brasil, portanto, é um esforço de existência relativamente recente, que pode ser atribuído em grande medida ao movimento Sanitarista.

Com o desenvolvimento dogmático da ciência do Direito no Brasil, que aos poucos foi se apropriando das concepções da Constituição Federal, passou-se a defender a imperatividade dos princípios e normas constitucionais, que deveriam produzir efeitos imediatos em todo o ordenamento jurídico. Naturalmente, direitos humanos constitucionalizados como a saúde passaram a ser exigidos perante o Poder Judiciário, de quem a apreciação de nenhuma lesão ou ameaça a direito pode ser afastada (art.5, XXXV) (MAPELLI JÚNIOR, 2017).

A previsão desse direito como direito de todos e dever do Estado, como será abordado nos próximos capítulos, passou a se configurar como verdadeira obrigação para o Poder Público

\footnotetext{
${ }^{12}$ De acordo com o art. XXV da Declaração Universal dos Direitos Humanos, proclamada na Assembleia Geral das Nações Unidas, em 10 de dezembro de 1948: "Todo ser humano tem direito a um padrão de vida capaz de assegurar a si e a sua família saúde e bem-estar, inclusive alimentação, vestuário, habitação, cuidados médicos e os serviços sociais indispensáveis, e direito à segurança em caso de desemprego, doença, invalidez, viuvez, velhice ou outros casos de perda dos meios de subsistência fora de seu controle".
} 
e direito subjetivo para o cidadão, mas, assim como sua efetivação encontrou dificuldades no passado, devido sua segregação a determinados grupos, falta de financiamento e corrupção, no atual contexto neoliberal constitui-se um verdadeiro desafio, principalmente num país com tanta restrição fiscal, pois sua efetivação depende da criação de uma organização e infraestrutura de custo elevado.

No atual Estado Brasileiro, evidencia-se a retomada do discurso segundo o qual a Constituição Dirigente de políticas públicas, dos direitos sociais, promove o desencontro com interesses nacionais. Conforme ressalta Moraes (2011) esse discurso acusa a Constituição dirigente de ter o condão de fomentar crises econômicas e produzir a ingovernabilidade, invertendo, por conseguinte a vontade da Constituição de 1987/1988 na "Constituição dirigente das políticas neoliberais de ajuste fiscal". Todavia, experiências internacionais já indicaram a precariedade da veleidade neoliberal a apontar a insanidade de substituir a racionalidade coletiva simplesmente pelas leis de economia de mercado (MORAES, 2011, p. 245).

Nesse contexto, após a aprovação do processo de impeachment pelo Senado, e assunção do governo interino no mês de maio de 2016, o retorno à concepção de Estado Regulador ${ }^{13}$ no Brasil está a exigir uma redução da atuação Estatal na consecução dos serviços públicos que atingem direitos fundamentais. Além da limitação de despesas na área da saúde ${ }^{14}$, outras propostas de caráter neoliberal como a criação de planos de saúde acessíveis ${ }^{15}$ demonstram uma

\footnotetext{
${ }^{13}$ Quanto à expressão "Estado Regulador", Avelã Nunes explica que, a partir da década de 70 do Séc. XX, com a crise do Keynesianismo, a ideologia neoliberal passou a ganhar força e se consolidou como ideologia dominante, sobretudo na Europa, onde assistiu-se a uma onda de privatizações de empresas públicas, mesmo na área dos serviços públicos. Surgindo uma nova feição de Estado Capitalista: o Estado Regulador. A função reguladora teria sido inventada para responder à necessidade, perante as privatizações, de resguardar o interesse público. Contudo, para o autor, a expressão correta seria, Estado "pseudo-regulador" uma vez que a função reguladora tende a ser exercida por agência (ou autoridades) reguladoras independentes que "não prestam contas perante nenhuma entidade legitimada democraticamente, nem perante o povo soberano (NUNES, Antônio José Avelãs. Breve reflexão sobre o chamado estado regulador. Revista Sequência, n 54, UFSC, Florianópolis, SC, Brasil, jul. 2007, p. 9-18).

${ }^{14}$ A Emenda Constitucional $n^{\circ}$ 95, de 15.12.16, alterou o texto constitucional para instituir o Novo Regime Fiscal. Trata-se de uma limitação ao crescimento das despesas do governo brasileiro durante 20 anos, alcançando os três poderes, além do Ministério Público da União e da Defensoria Pública da União. De acordo com a emenda, a partir de 2018, os gastos federais só poderão aumentar de acordo com a inflação acumulada conforme o Índice Nacional de Preços ao Consumidor Amplo (IPCA). Saúde e educação terão tratamento diferenciado. Para 2017, a saúde terá $15 \%$ da Receita Corrente Líquida, que é o somatório arrecadado pelo governo, deduzido das transferências obrigatórias previstas na Constituição. A educação, por sua vez, ficará com $18 \%$ da arrecadação de impostos. A partir de 2018, as duas áreas passarão a seguir o critério da inflação (IPCA). No Estado do Ceará, a Emenda Constitucional $n^{\circ} 88$, de 21.12.16, acrescentou dispositivos à Constituição do Estado do Ceará, com alterações semelhantes às de âmbito nacional, estabelecendo limite de gastos pelos próximos 10 anos, preservando os percentuais orçamentários a serem aplicados em saúde e educação.

15 Enfatizando que o subfinanciamento das ações públicas de saúde, que encontrou acolhimento no ideário neoliberal, constitui um dos maiores obstáculos do SUS, Pereira sustenta que a iniciativa de regulamentar mais uma espécie de plano de saúde, com cobertura sabidamente reduzida (como é o caso dos Planos de Saúde Popular ou Acessíveis), em que a assistência prevista na cobertura seria básica ou de baixa complexidade e custo, tem como finalidade afastar quem contratar esse tipo de assistência suplementar da Atenção Básica do SUS, ferindo os ditames constitucionais, uma vez que significam uma omissão estatal incompatível com a Constituição, que
} 
forte tendência à precarização do SUS, por potencializar a lógica do mercado no atendimento à saúde, que passa mais do que nunca a ter o caráter de direito individual em detrimento da política de saúde pública coletivamente organizada.

Outra conclusão a que se chega a partir de uma análise da evolução das políticas públicas, é a da existência de todo um aparato técnico e administrativo tradicionalmente concentrado no Poder Executivo Estatal, responsável por pensar e executar as políticas de saúde, dotadas de organização e regramentos próprios, que devem ser considerados quando da judicialização do tema.

Compreender o sentido dos princípios constitucionais que regem a saúde, como por exemplo, a universalidade e a igualdade, é de suma importância para o estudo da judicialização da saúde, pois apesar do desatendimento a esses princípios abrir possibilidade para a intervenção judicial nas políticas públicas de saúde, entende-se que o resultado dessa intervenção também não deve infringir tais princípios.

A judicialização da saúde, com frequência, encontra-se diante de dilemas, relacionados aos princípios: da universalidade, que obrigaria o Estado a dispensar a atenção necessária à saúde de todos os brasileiros e estrangeiros residentes no Brasil; da integralidade, que garantiria ao cidadão o direito de ser atendido e assistido sempre que necessitar, em qualquer situação ou agravo; e da igualdade, pelo qual o Poder Público estaria obrigado a oferecer atendimento igual para todos, sem qualquer privilégio. Tais dilemas ocorrem quando a judicialização excessiva acaba provocando um desrespeito a alguns desses princípios, gerando privilégios (igualdade) ou redirecionando recursos de modo a prejudicar a prestação do serviço de qualidade de forma coletiva (universalidade), sobre o que se discorrerá mais adiante.

estabelece a universalidade e a unicidade do sistema. (PEREIRA, Fabrícia Helena Linhares Coelho da Silva Pereira. Direito à saúde: entre o dever estatal e a participação privada. Dissertação de Mestrado apresentada ao Programa de Pós-Graduação em Direito da Faculdade de Direito da Universidade Federal do Ceará, como requisito parcial para obtenção do Título de Mestre em Direito. Fortaleza, 2018. Disponível em: < http://www.repositorio.ufc.br/bitstream/riufc/36829/1/2018_dis_fhlcspereira.pdf>. Acesso em: 02 jan 2019). Referida autora, cita Carlos Octávio Ocke-Reis, que, destacando a ausência de um projeto atual que fortaleça o Sistema Único de Saúde, de valorização do significado da luta histórica e política pela existência do SUS - modelo conquistado após 1988 - sugere que existência de projeto de setores economicistas no Estado e na sociedade de uma visão meramente fiscalista visa fomentar o mercado de planos de saúde como uma solução pragmática para os ditos problemas do sistema público de saúde, como a oneração das contas públicas (In OCKÉ-REIS, Carlos Octávio. SUS: o desafio de ser único. Rio de Janeiro: Editora Fiocruz, 2012, p.11). Mariano et al, referindo-se as propostas de planos de saúde com cobertura reduzida, defende que acabam ferindo o modelo constitucional de Estado de Bem-Estar Social a fim de transformar a saúde pública em assunto da iniciativa privada, comprometendo o futuro do Sistema Único de Saúde e das conquistas históricas que ele representa para o cidadão brasileiro. (In MARIANO, Cynara Monteiro; PEREIRA, Fabrícia Helena Linhares Coelho da Silva. Mais um obstáculo ao SUS: o caso dos planos de saúde populares. A\&C - Revista de Direito Administrativo e Constitucional, ano 18, n. 72, p. 115-132, ab./jun. 2018). 
No próximo subtópico busca-se fazer breve retrospecto e análise das políticas de saúde públicas desenvolvidas no âmbito do Estado do Ceará.

\subsection{A política de saúde pública no Estado do Ceará:}

Barbosa (2017) em uma análise da interface existente entre poder político e as políticas públicas de saúde, ressalta que as transformações econômicas e sociais ocorridas ao longo da história do país refletiram e ainda se refletem na realidade do Estado. Contudo, alerta para outros fatores que devem ser considerados no estudo de políticas públicas em saúde, como aspectos culturais, individuais, climáticos e epidemiológicos: as secas e as epidemias, por exemplo, alteraram os rumos das políticas públicas de saúde no Ceará.

Retrocedendo aos anos 1836/1837 pode-se encontrar um dos primeiros registros relacionados à saúde pública no Estado do Ceará. Nessa época, por lei, o cargo de cirurgiãomor da província foi extinto e foi criado o cargo de médico da pobreza, com a finalidade de promover uma ação de caridade do governo para com os menos afortunados. Referidos agentes possuíam como atribuições básicas: residir na cidade, curar todos os pobres, (inclusive presos) e nos casos de necessidade, visitar e vacinar os doentes (GADELHA, 2012).

Destacou-se também, no final do séc. XIX e início do séc.XX, o movimento médico higienista, na cidade de Fortaleza, que teve como ação de saúde pública de maior envergadura, desenvolvida em paralelo ao Poder Constituído do Estado, o combate a varíola. Essa ação foi patrocinada pelo farmacêutico, escritor e cientista Rodolfo Theófilo, testemunha da epidemia de varíola que atingiu o Ceará em 1878, que resolveu por conta própria combater a doença, através da produção da vacina e imunização da população (BARBOSA, 2017).

Apesar dessas iniciativas, não se pode afirmar, que ao longo do séc. XX o poder estadual promoveu o desenvolvimento de um aparato biopolítico para atender a necessidade da população. À sua época, Rodolfo Theófilo criticou o Estado cearense e a ausência de medidas profiláticas contra a varíola, o que poderia ter evitado o agravamento da epidemia (CORREIA, 2014).

A mais antiga instituição que teve como objetivo cuidar da saúde dos cearenses foi a Inspetoria de Saúde Pública, criada através da Lei $n^{\circ}$ 7, de 11 de fevereiro de 1882, órgão vinculado à Secretaria dos Negócios do Interior, que influenciada por práticas higienistas praticadas na Capital da República (Rio de Janeiro) e São Paulo promovia ações coletivas de vigilância epidemiológica, vigilância sanitária e vacinação contra a varíola. $\mathrm{O}$ atendimento individual e curativo não era exercido rotineiramente pelo Poder Público, continuando a 
apresentar caráter caritativo para quem não tinha condições financeiras, "sendo feito pelos médicos, em seus consultórios, e quase que exclusivamente pela Santa Casa de Misericórdia, no caso de internações" (BARBOSA, 2017, p. 64).

Em 1913, quando a varíola retorna a fazer vítimas em todo o estado, se observa um incremento na criação de instituições de saúde pública, fazem parte desses marcos institucionais (MONTESUMA et al., 2006).

a) a fundação do Centro Médico Cearense, que, sob a presidência do Dr. Guilherme Studart (Barão de Studart), consolida a assistência médica, estabelece um fórum de debates sobre problemas de saúde da região e oportuniza a troca de opiniões técnicas entre profissionais;

b) a instalação da Faculdade de Farmácia e de Odontologia;

c) a fundação do primeiro serviço de assistência à mulher, em 1915, a Maternidade João Moreira, hoje Hospital Geral César Cals, nome de seu primeiro diretor;

d) a fundação do Instituto de Proteção e Assistência à Infância que, sob o comando do Dr. Abdenago da Rocha Lima, multiplica consultórios de puericultura, qualifica a assistência domiciliar ao parto e reduz a mortalidade infantil de 416 por mil em 1916, para 237 em 1930;

e) a criação do Instituto Pasteur no Ceará, pelo farmacêutico Afonso de Pontes Medeiros e pelo médico Carlos Ribeiro, serviço filantrópico de análises clínicas;

f) a criação do Serviço de Profilaxia Rural do Ceará, em 1920, com o objetivo de combater as três maiores endemias rurais, ancilostomíase, malária e doença de Chagas, motivando a formação de sanitaristas e desdobrando, em 1926, com o apoio da Fundação Rockfeller, um combate efetivo à febre amarela; e

g) a construção da Santa Casa de Misericórdia de Sobral, primeiro esforço de interiorização da assistência hospitalar.

A epidemia de gripe espanhola no Ceará, no ano de 1918, foi um marco importante para a saúde pública local. Na capital cearense, que não contava com um serviço público de atendimento individual, sequer ambulatorial, organizou-se emergencialmente sete postos de atendimento e foram contratados médicos em caráter provisório, os chamados comissionados. Para várias cidades, a Diretoria de Saúde Pública contratou médicos para prestar assistência à população. Desde então, houve uma reestruturação no órgão responsável pela saúde no Estado (BARBOSA, 2017).

O caráter centralizador e autoritário que emergiu da Revolução de 30, deu ao país pela primeira vez, uma política nacional de saúde. O Ceará foi especialmente beneficiado no setor da saúde, onde ocorreram significativas transformações, como a criação do "Serviço Sanitário do Estado", em 1931, que extinguiu o Serviço de Profilaxia Rural e a criação da Diretoria de Saúde Pública, em 1933, que ficou sob a direção de Almícar Barca Pellon, responsável por grandes reformas na saúde, criando uma estrutura que permaneceu praticamente inalterada até 1939, quando por intermédio do Decreto $\mathrm{n}^{\circ} 522$, do mesmo ano, foram reestruturados os 
serviços de saúde pública do estado, criando-se o Departamento Estadual de Saúde ${ }^{16}$ (BARBOSA, 2017).

Essa nova estrutura, contudo, perdeu aos poucos o seu caráter de órgão voltado para a prevenção de doenças e, no final da década de 40, o Centro de Saúde e as Unidades Sanitárias do interior transformaram-se quase totalmente em pronto atendimento, com serviços unicamente ambulatoriais e a falta de investimentos foi defasando em muito os serviços para a população (BARBOSA, 2017). Com relação a estruturação dos serviços de saúde no âmbito da capital, cumpre destacar que:

\begin{abstract}
A Prefeitura Municipal de Fortaleza tinha uma participação muito pequena nos serviços de saúde. A Diretoria-Geral de Saúde que existiu até 1948, contava com apenas dois serviços: o Pronto Socorro Municipal, criado em 1933, e a Inspetoria de Assistência Sanitária aos Matadouros. Em 1948, através da Lei no 70, de 25 de junho, foi criada a Secretaria Municipal de Saúde. [...] Pela Lei $n^{\circ}$ 2.486, de 26 de outubro de 1963, houve uma reestruturação da Secretaria Municipal de Saúde e Assistência (SMSA), distribuindo-se assim suas atividades: Hospital Pronto Socorro, Departamento de Assistência Médico-dentária, Junta Médica Municipal, Departamento de Higiene e Seção Administrativa (BARBOSA, 2017, p. 117).
\end{abstract}

Em 1938, a assistência médica incorporou-se à estrutura previdenciária, iniciando-se o processo de compras de serviços médico-hospitalares e ambulatoriais à rede privada. A partir de então, passaram a conviver dois sistemas: um público pertencente ao Estado e o outro privado, conveniado aos institutos previdenciários. A reforma Pelon e o momento econômico deram amparo a privatização: "o Sanatório de Messejana, em 1933; a Casa de Saúde de São Gerardo (Psiquiatria), em 1935; a casa de Saúde São Raimundo, 1939, e a Casa de Saúde São Pedro, em 1939, são frutos de tal processo". Ressalte-se, contudo, a existência de um desequilíbrio gritante, pois o interior do Estado, que contava com 91\% da população, recebia apenas 30\% das exíguas verbas destinadas à saúde (MONTEZUMA, 2006, p. 14)

Com a criação do Ministério da Saúde, em 1950, começaram a surgir Secretarias de Saúde em vários estados do país, o que só ocorreu no Ceará, em 1961, com a instituição da Secretaria de Saúde e Assistência. Essa nova Secretaria passou a ter a seguinte estrutura: Departamento Estadual da Criança, Departamento de Assistência Hospitalar, Conselho Técnico

\footnotetext{
${ }^{16}$ Segundo Barbosa: “A principal característica da 'Reforma Pellon' foi o sistema de divisão distrital, segundo o qual as cidades e municípios são divididos em distritos sanitários, constituídos por áreas delimitadas, cada área servia a uma determinada população e concentrava todas as atividades sanitárias de forma hierarquizada, obedecendo a um comando único. Este modelo de organização sofreu grande influência da estrutura sanitária norte-americana, com uma forte centralização da direção e descentralização dos serviços, através de três tipos de unidades: Centros de Saúde, Postos de Higiene e Subpostos de Higiene." O Centro de Saúde, localizado em Fortaleza, contava com condições técnicas para dirigir e auxiliar as demais unidades sanitárias do estado, foi o primeiro estabelecimento deste tipo no Nordeste e representou um considerável avanço para a saúde pública do Ceará (BARBOSA, José Policarpo de Araújo. Saúde \& Poder: uma história das instituições de saúde pública do Estado do Ceará. Fortaleza: RDS, 2017, p. 89).
} 
de Saúde e Assistência Social, o Conselho Estadual de Saúde e o Serviço Social do Estado (BARBOSA, 2017).

A partir de 1964, a Secretaria de Saúde passou por um longo período de desestruturação e descrédito. Barbosa (2017, p. 151) lista alguns fatores determinantes para essa situação:
a) A política governamental passou a privilegiar a medicina curativa, principalmente, através da compra de serviços a entidades privadas via previdência social;
b) Os poucos recursos existentes eram gastos nos hospitais, enquanto que os centros e postos de saúde foram abandonados à própria sorte;
c) O clientelismo propiciava, a cada eleição, a contratação indiscriminada de funcionários, sem concurso e sem a mínima capacitação para o cargo;
d) A direção da Secretaria, bem como todas as instâncias administrativas passaram a ser nomeadas obedecendo critérios politiqueiros;
e) Os salários tornaram-se aviltantes.

Os hospitais passaram a assumir posição central na prestação de serviços de saúde. Além do aumento dos leitos privados, o INPS construiu, em 1966, o Hospital Geral de Fortaleza com 250 leitos (BARBOSA, 2017). A instituição da Fundação de Saúde do Estado do Ceará (FUSEC), através da Lei $\mathrm{n}^{\circ}$ 9.497, de 20 de julho de 1971, consolidou essa tendência de enfraquecimento da Secretaria de Saúde do Estado, na medida em que consistia num instrumento poderoso de centralização administrativa das ações hospitalares do estado e de exercício de poder político, principalmente no interior, através do clientelismo, com a contratação de pessoal e nomeação dos dirigentes hospitalares ${ }^{17}$ (BARBOSA, 2017).

A Secretaria de Saúde voltou a assumir relevância com interiorização da medicina, através da criação do Programa de Interiorização das Ações de Saúde e Saneamento (PIASS), implantado no Ceará, em 1977, havendo considerável investimento do Governo Federal, que propiciou o aumento da rede básica de saúde no interior do estado, que passou a ser gerida pela mesma (BARBOSA, 2017).

A efervescência política que veio desaguar na VIII Conferência Nacional da Saúde apresentou propostas concretas de reforma para o setor, que foram garantidas em parte pela Constituição de 1988, todavia, repetidos governos conservadores passaram a dificultar a implementação dessas reformas. No Ceará, duas eleições marcaram essas mudanças: a primeira

\footnotetext{
${ }^{17} \mathrm{O}$ autor destaca que, apesar de contar com um Conselho Administrativo presidido pelo Secretário de Saúde do Estado, que teoricamente seria superior à Diretoria Executiva presidida pelo Superintendente, na prática a FUSEC tinha total autonomia em relação à Secretaria de Saúde: "O cargo de superintendente passou a ser mais cobiçado que o de Secretário de Saúde, contava com maior orçamento e principalmente, com maior liberdade de contratação de pessoal." Essa autonomia administrativa de que gozavam os superintendentes da FUSEC propiciava o surgimento de vários escândalos administrativos, como, por exemplo, os referentes a contratação de pessoal em troca de votos nos períodos eleitorais. Após crescente enfraquecimento da Instituição a partir do Governo Tasso Jereissati, 1987, sua extinção se deu no Governo Ciro Gomes, através do Decreto Lei no 21.383/91 (BARBOSA, José Policarpo de Araújo. Saúde \& Poder: uma história das instituições de saúde pública do Estado do Ceará. Fortaleza: RDS, 2017, p. 154).
} 
de Maria Luiza Fontenele para a Prefeitura de Fortaleza; e a segunda, de Tasso Jereissati para o Governo do Estado, iniciando um longo período de mudanças na saúde: como a reforma sanitária no Estado; a municipalização; a extinção da FUSEC; a estadualização dos hospitais da previdência e os programas que melhoram os indicadores de saúde: o Programa de Agentes de Saúde ${ }^{18}$ e o Viva a Criança (BARBOSA, 2017, p. 169).

A partir da vigência da Constituição Federal de 1988, a Secretaria da Saúde do Estado - SESA, passou a assumir o papel de Coordenadora Estadual do SUS, e, em 1991, em decorrência da extinção da Fundação de Saúde do Estado do Ceará - FUSEC, a SESA se tornou responsável pelo gerenciamento de todas as Unidades de Saúde Estaduais:

Em 1989, com o início do processo de municipalização, as Unidades Básicas, os Centros de Saúde e os Hospitais de Nível Secundário Estaduais foram cedidos para os Municípios, ficando a SESA com o gerenciamento de Unidades Ambulatoriais Especializadas e Hospitais Terciários localizados em Fortaleza (COELHO; LIMA, 2018, p.35).

Nos anos 90, diversas Normas Operacionais Básicas da Saúde (NOBS) editadas pelo Ministério da Saúde contribuíram para o avanço da descentralização das ações e serviços de saúde para os municípios, no entanto, não avançaram no que dizia respeito à regionalização como estratégia para a descentralização, apenas faziam-lhe referência, sem tratar da sua operacionalização. A regionalização como estratégia ganha maior destaque a partir das Normas Operacionais de Assistência à Saúde no SUS (NOAS 01/2001 e NOAS/2002):

Essas NOAS apresentam a regionalização como estratégia para organização do
sistema no território, com o objetivo de promover mais equidade no acesso da
população às ações e serviços de saúde. Nesse sentido, apresentam os conceitos de
módulos assistenciais, microrregiões, macrorregiões e regiões de saúde e propõem o
Plano Diretor de Regionalização (PDR) como instrumento de distribuição e
articulação das ações e serviços assistenciais nos distintos territórios. As NOAS
fortaleceram o papel do gestor estadual, que passa a assumir a coordenação do
processo de regionalização e da organização das referências intermunicipais de seu
território (AGUIAR, 2015, p. 120). Cumpre ressaltar, que após a realização de uma experiência-piloto microrregião de Baturité, em 1999, com o apoio e cooperação técnica e financeira do Departament for

\footnotetext{
${ }^{18}$ A experiência com a implantação do PACS no Estado do Ceará, programa com objetivo central contribuir para a redução da mortalidade infantil e mortalidade materna, principalmente nas regiões Norte e Nordeste, através de extensão de cobertura dos serviços de saúde para as áreas mais pobres e desvalidas, demonstrou ao Ministério da Saúde que os agentes poderiam também ser peça importante para a organização do serviço básico de saúde no município, podendo-se afirmar que o PACS é um antecessor do PSF: "pois uma das variáveis importantes que o primeiro introduziu e que se relaciona diretamente com o segundo é que pela primeira vez há um enfoque na família e não no indivíduo, dentro das práticas de saúde." (D’AVILA, Ana Luiza; POZ, Mario Roberto Dal. A Reforma do Sistema de Saúde no Brasil e o Programa de Saúde da Família. PHYSIS: Rev. Saúde Coletiva, Rio de Janeiro, 2005, 15(Suplemento):p. 225- 264.) Disponível em: <https://www.scielosp.org/pdf/physis/2005.v15suppl0/225-264>. Acesso em 02 jan 2019.
} 
Internacional Development do Reino Unido (DFID), articulada com o Governo do Estado, Secretaria Estadual de Saúde (SESA) e a Escola de Saúde Pública do Ceará - ESP-CE, a Secretaria de Saúde do Estado (SESA) realizou avaliação envolvendo os agentes que participaram da experiência e procedeu aos ajustes necessários, definindo a expansão da implantação das microrregiões. A implantação das microrregiões no Estado do Ceará antecedeu, portanto, a Norma Operacional de Assistência à Saúde (NOAS), instituída pelo Ministério da Saúde em 2001 (ANDRADE, 2007).

Ao se proceder uma análise dos últimos trinta anos de desenvolvimento da política pública de saúde desenvolvida no Estado do Ceará, podem ser considerados como destaques:

a) a redução da mortalidade infantil e de doenças preveníveis por imunização, persistências de doenças cardiovasculares e cânceres, aumento das mortes violentas e relacionadas à AID Epidemia de dengue (1987-1990);

b) a ampliação da cobertura da assistência básica, redução da mortalidade infantil, epidemia de cólera (1991-1994);

c) a regionalização de serviços especializados em 21 microrregiões em 3 macrorregiões de saúde, a assunção pelos municípios de serviços básicos e especializados ( $1^{\circ}$ nível de complexidade) e a implantação da Central de Transplantes (1995-2002);

d) o Programa "Saúde Mais Perto de Você", financiado com recursos estaduais a assistência prestada pelos hospitais públicos municipais e filantrópicos integrantes do setor complementar do SUS (2003-2006);

e) a expansão da rede especializada PROEXAMES, modelo de gestão consorciada, responsabilidade de prestação de serviços de saúde e comando único dos prestadores assumido pelos municípios, implantação do modelo de atenção as Redes de Atenção de Saúde e avanço do processo de judicialização (2007-2014);

f) a redução da TMI Neonatal (menos de 28 dias); elevação da taxa de incidência de sífilis congênita, redução a partir de 2013, das transferências de pacientes regulados pelo CRESUS (2015-2016) (COELHO; LIMA, 2018, p.72).

No Estado do Ceará, ainda, a organização do modelo assistencial se verifica no Plano Diretor de Regionalização - PDR/Ceará, que expressa de forma regionalizada, o acesso aos serviços de saúde, a sua abrangência e responsabilidades na atenção básica em cada município, organizado em 22 regiões de saúde com capacidade resolutiva para a média complexidade ${ }^{19}$ e 5 macrorregiões de saúde (Fortaleza, Sobral, Sertão Central, Cariri e Leste Jaguaribe) com capacidade resolutiva a ser implantada gradativamente na alta complexidade cuja referência se dá nas Centrais de Regulação destas regiões de saúde, em cumprimento a uma pactuação formalizada na Programação Pactuada Integrada - PPI, cumprindo, neste processo, os princípios da equidade, a garantia da integralidade, a qualidade do processo de descentralização, a racionalização dos gastos e otimização dos recursos (CEARÁ, 2016).

\footnotetext{
${ }^{19}$ Essas regiões são: $1^{\mathrm{a}}$ Fortaleza, $2^{\mathrm{a}}$ Caucaia, $3^{\mathrm{a}}$ Maracanaú, $4^{\mathrm{a}}$ Baturité, $5^{\mathrm{a}}$ Canindé, $6^{\mathrm{a}}$ Itapipoca, $7^{\mathrm{a}}$ Aracati, $8^{\mathrm{a}}$ Quixadá, 9 $9^{\mathrm{a}}$ Russas, $10^{\mathrm{a}}$ Limoeiro do Norte, $11^{\mathrm{a}}$ Sobral, $12^{\mathrm{a}}$ Acaraú, $13^{\mathrm{a}}$ Tianguá, $14^{\mathrm{a}}$ Tauá, $15^{\mathrm{a}}$ Crateús, $16^{\mathrm{a}}$ Camocim, $17^{\mathrm{a}}$ Icó, $18^{\mathrm{a}}$ Iguatu, $19^{\mathrm{a}}$ Brejo Santo, 20 Crato, $21^{\mathrm{a}}$ Juazeiro do Norte e $22^{\mathrm{a}}$ Cascavel.
} 
De acordo com o Decreto $\mathrm{n}^{\circ} 7.508 / 11$, cada região de saúde consiste em espaço geográfico contínuo constituído por agrupamento de municípios limítrofes, delimitadas a partir de identidades culturais, econômicas e sociais e de redes de comunicação e infraestrutura de transportes compartilhados, com a finalidade de integrar a organização, o planejamento e a execução de ações e serviços de saúde.

No tocante à oferta de serviços básicos nos municípios e de serviços especializados nas regiões de saúde ressalte-se que foi ampliada às custas grandes investimentos, de recursos do próprio Estado, todavia, nesse processo de descentralização, acabaram sendo transferidas muitas responsabilidades nas prestações dos serviços para os municípios, sem a devida regulação do Estado:

\begin{abstract}
Apesar das iniciativas tais como os consórcios públicos, resta debilitada a governança do sistema, por exemplo, na definição dos arranjos assistenciais próprios de cada região de saúde. A manutenção e o custeio das novas estruturas implantadas, em pleno funcionamento, manifesta-se com difícil sustentabilidade financeira. Assume perspectiva ainda mais complicada diante do novo regime fiscal estabelecido, com congelamento do gasto público, nos próximos 20 anos. Portanto há necessidade de uma mudança no modelo de atenção à saúde, com efetivo investimento nos cuidados primários, com pesquisa e inovação tecnológica, para enfrentar os desafios do atual epidemiológico e garantir integralidade do cuidado (COELHO; LIMA, 2018, p.5).
\end{abstract}

Cada região conta com um órgão de representação da Secretaria Estadual da Saúde, denominada Coordenadoria Regional de Saúde - CRES $^{20}$ que tem dentre suas atribuições a implementação das políticas estaduais de saúde em âmbito regional. Referidas Coordenadorias Regionais de Saúde deverão se utilizar de mecanismos gerenciais para o desenvolvimento de suas atribuições, entre os quais se situam, além do Plano Diretor de Regionalização, Plano Plurianual e Plano Anual de Saúde, outros instrumentos, tais como:

a) Contrato Organizativo da Ação Pública da Saúde - COAP: acordo de colaboração firmado entre entes federativos (União, Estado e Municípios) com a finalidade de organizar e integrar as ações e serviços de saúde na rede regionalizada e hierarquizada, com definição de responsabilidade, indicadores e metas de saúde, critérios de avaliação de desempenho, recursos financeiros que serão disponibilizados, formas de controle e fiscalização de sua execução e demais elementos necessários à implementação integrada das ações e serviços de saúde (Decreto $n^{\circ} 7.508$ de 28 junho de 2011;

b) Plano Diretor de Investimento (PDI) que é o instrumento que define o perfil de atendimento e necessidades de investimento das unidades de saúde do Sistema Único de Saúde, baseado no Plano Diretor de Regionalização;

c) Programação Pactuada e Integrada (PPI): Programação Pactuada e Integrada expressa as responsabilidades do Estado e dos municípios para a assistência à saúde da população, organizada de modo regionalizado, hierarquizado e integrado, orientada atualmente pelo Plano Diretor de Regionalização da Saúde do Estado.

${ }^{20}$ Com exceção da região de Cascavel, criada pela Resolução n. ${ }^{\circ}$ 10/2005 do Conselho Estadual de Saúde CESAU, que ficará técnico-administrativamente sob a responsabilidade da Coordenadoria Regional de Fortaleza. 
d) Plano Estadual de Saúde, Instrumento que orienta a gestão do SUS estadual. Apresenta as intenções e os resultados a serem buscados no período de quatro anos, expressos em objetivos, diretrizes e metas. ${ }^{21}$

Impende ressaltar que, ainda conforme o Decreto $\mathrm{n}^{\mathrm{o}} 7.508 / 11$, o processo de planejamento da saúde será ascendente e integrado, do nível local até o federal, ouvidos os respectivos Conselhos de Saúde, compatibilizando-se as necessidades das políticas de saúde com a disponibilidade de recursos financeiros. A ascendência do processo de orçamento e planejamento do SUS, também se encontra na Lei Complementar $\mathrm{n}^{\circ} 141 / 12$, assim determina:

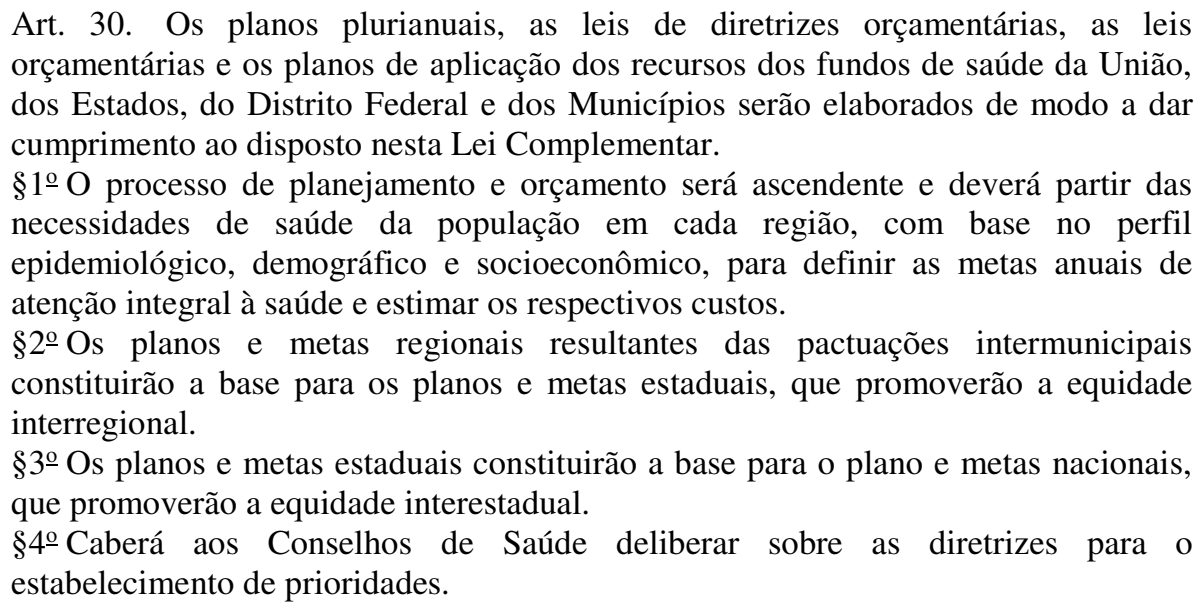

Impende ressaltar que para a identificação das necessidades de saúde e orientação do planejamento integrado dos entes federativos serão utilizados mapas da $\operatorname{saúde}^{22}$, que contribuirão para o estabelecimento de metas.

Ao tratar da estruturação da regionalização do SUS, o Decreto n ${ }^{\circ} 7.508 / 11$ apresenta o conceito de Rede de Atenção em Saúde como sendo: o conjunto de ações e serviços de saúde articulados em níveis de complexidade crescente, com a finalidade de garantir a integralidade da assistência à saúde. As redes de atenção podem abarcar uma ou várias regiões, sendo necessário a articulação entre os gestores para a organização dos fluxos e mecanismos de integração. No que concerne à hierarquização dos serviços, determina-se que o acesso se inicie pelas portas de entrada do SUS e se complete na rede regionalizada e hierarquizada, de acordo

\footnotetext{
${ }^{21}$ Disponível em: <https://www.saude.ce.gov.br/2018/07/03/coordenadorias-regionais/>. Acesso em 02 jan 2019. ${ }^{22}$ A definição de Mapa da Saúde, disposta no Decreto $\mathrm{n}^{\circ}$ 7.508/11, consiste na: "descrição geográfica da distribuição de recursos humanos e de ações e serviços de saúde ofertados pelo SUS e pela iniciativa privada, considerando-se a capacidade instalada existente, os investimentos e o desempenho aferido a partir dos indicadores de saúde do sistema”.
} 
com a complexidade do serviço (AGUIAR, 2015, p.123) ${ }^{23}$. O Estado do Ceará elencou como compromisso prioritário a organização das Redes Temáticas:
a) Rede Cegonha - atenção obstétrica e neonatal, hoje denominada de Materno Infantil;
b) Rede de Cuidados a Pessoa com Deficiência;
c) Rede de Atenção às Urgências e Emergências;
d) Rede de Atenção Psicossocial, enfrentamento do Álcool, Crack, e outras Drogas;
e) Rede de Atenção à Saúde Bucal;
f) Rede de Atenção as Condições Crônicas: câncer (a partir da intervenção no câncer de colo de útero e mama), cardiovascular; e Rede de Atenção Oftalmológica (CEARÁ, 2016, p. 14).

Quanto às ações de assistência farmacêutica, cuja execução foi garantida através da Constituição 1988 e da normatização da Política Nacional de Medicamentos, foi determinada uma reorientação que estabeleceu responsabilidades aos gestores das três esferas de governo, trazendo um fato novo para estados e município: a aquisição descentralizada de medicamentos. Diante dessa nova realidade, visando racionalizar e otimizar os recursos disponíveis para o Incentivo à Assistência Farmacêutica (IAFB), no Ceará, em 1999, de forma pioneira no Brasil houve uma articulação dos municípios, em parceria com o Estado, pactuando na Comissão Intergestores Bipartite (CIB) e no Conselho estadual de Saúde um sistema de compra centralizada para a aquisição de medicamentos, denominada Programação Pactuada Integrada de Assistência Farmacêutica Básica:

[...] a Secretaria de Saúde do Estado do Ceará, por meio da Coordenadoria de Assistência Farmacêutica (COASF-SESA), gerencia desde 1999 cerca de um terço de todos os recursos destinados à aquisição de medicamentos para a assistência farmacêutica básica, promovendo uma grande economia de escala principalmente para os municípios de pequeno e médio porte. Dentre outras situações, essa economia possibilitou principalmente a ampliação do elenco de medicamentos disponibilizados para a atenção básica fazendo com que o número de itens adquiridos passasse de 58 em 1999 para 168 em 2015 (CEARÁ, 2016, p. 125).

Novamente, o Estado do Ceará apresentou-se como pioneiro no Brasil, dessa vez em relação aos agravos que não possuem cobertura farmacoterapêuticas enquadrados nos componentes de financiamento da Assistência Farmacêutica (básico, estratégico e especializado), posto que devido aos frequentes expedientes administrativos e judiciais, tanto das secretarias municipais e estaduais, no ano de 2009 criou-se a nível nacional a política de

\footnotetext{
${ }^{23}$ Constituem portas de entrada para as redes de atenção os serviços de atenção primária, de atenção de urgência e emergência, de atenção psicossocial e serviços especiais de acesso aberto. O atendimento aos usuários se dará inicialmente nesses serviços, após, serão referenciados para outros serviços de atenção hospitalar ou ambulatórios de especializadas, ou outros de maior complexidade e densidade tecnológica, conforme necessidade do usuário (Decreto $\left.\mathrm{n}^{\circ} 7.508 / 11\right)$.
} 
assistência farmacêutica secundária, a ser financiada por estados e municípios aderentes a mesma (CEARÁ, 2016).

A participação da União nos gastos em saúde por esfera de governo passou de $72 \%$ em 1993 para 42\% em 2015, enquanto o conjunto dos estados passou de 12\% em 1993 para 27\% em 2015, e dos municípios brasileiros de 16\% em 1993 para 31\% em 2015. Com a aprovação da Emenda Constitucional No 95/2016 que trata da vigência do Novo Regime Fiscal por 20 anos, a despesa da União com ações e serviços de saúde de 2017 até 2036 será a mesma, em termos reais, da executada em 2016. O SUS no Ceará em 2013 contou com o montante de recursos no valor de $\mathrm{R} \$ 6.237$ milhões, financiado pelos três entes federados, cabendo à União $\mathrm{R}$ \$ 2.636 milhões $(42,3 \%)$, ao estado R 1.796 milhões $(28,8 \%)$ e aos municípios R 1.805 milhões $(28,9 \%)$ gerando um valor per capita de $\mathrm{R} \$ 710,37$. Em 2016 os recursos se elevaram para R 7.837 milhões, num aumento de $26,7 \%$, mas a participação da União se reduziu em 2,6\% (COELHO; LIMA, 2018).

No Estado do Ceará, o número de leitos cadastrados junto ao Cadastro Nacional de Estabelecimentos de Saúde - CNES, apresentou um aumento de 355 leitos entre os anos de 2008 a 2012, passando de 19.151 para 19.506 leitos, contudo, entre anos de 2012 a 2016, houve uma redução de 561 leitos, passando de 19.506 para 18.945. Sendo que, a cobertura de leitos por mil habitantes nos anos de 2008 e 2012 foi de 2,27, enquanto em 2016 passou para 2,11, o representou uma taxa de redução de 7\%. O número de leitos cadastrados em 2016 apresenta um acréscimo de 560 leitos em relação aos leitos cadastrados em 1985 (18.385 leitos), que representa um aumento de $3 \%$. No que se refere à cobertura de leitos por mil habitantes, nesse mesmo período, reduziu de 3,13 para 2,11 leitos por mil habitantes, uma redução de 32,6\%. Cumpre ressaltar que:

Comparando-se a cobertura do Estado com a do Nordeste e a do Brasil, constata-se que, em 2008, foi igual à média do Nordeste e abaixo da média do Brasil (2,43 por 1000habitantes), em 2012 foi superior à do Nordeste (2,19 por 1000 habitantes) e abaixo da média do Brasil (2,35 leitos por 1.000 habitantes) e em 2016 continua acima da média do Nordeste (2,02 por 1000 habitantes) e muito próxima da média do Brasil (2,12 leitos por 1.000 habitantes) (COELHO; LIMA, 2018, p.35).

A redução no número de leitos hospitalares é um problema que reflete imediatamente nos índices de judicialização da saúde, o que se discutirá ao longo dos próximos capítulos. A tendência de redução da oferta de leitos no período de 2008 a 2016 é observada não somente no Estado do Ceará, mas na Região Nordeste e no Brasil, fato que acaba implicando 
diretamente, na restrição do acesso da população aos serviços de saúde hospitalares (COELHO; LIMA, 2018) $)^{24}$.

O Estado ainda conta com uma estrutura que atualmente abrange 11 grandes hospitais, 30 UPAs, 19 policlínicas regionais, 25 Centros de Especialidades Odontológicas (CEOs) e 10 unidades especializados, chegando a ser considerado a maior rede pública acreditada do país. Ao longo dos anos de 2015 e 2016, a rede hospitalar do estado realizou 191.453 internações, havendo em 2016, um aumento de quase 7\% em relação a 2015 (17,98\% em relação a 2014). Isso representa 527 pacientes em média a cada mês. Já a mortalidade intrahospitalar nos dois anos foi reduzida em 2,98\% em relação ao último biênio ${ }^{25}$.

O número de cirurgias realizadas na rede pública estadual em 2016 (55.903) apresentou um incremento de 7,44\%, comparando-se ao ano de 2015 (52.030). Ranking nacional da Associação Brasileira de Transplantes de Órgãos (ABTO) situou o Estado do Ceará como primeiro lugar em transplantes de fígado no país, terceiro em transplantes em geral, o terceiro em doadores efetivos do Brasil. A gestão na saúde tem apresentado comprometimento com o melhor uso do recurso público para o atendimento mais eficaz ao cearense. Entre as iniciativas do governo estadual, situam-se ${ }^{26}$ :
a) Criação da central de distribuição de medicamentos;
b) Ponto de expediente para médicos;
c) Melhoria no atendimento a ostomizados e a crianças com alergia à proteína do leite;
d) Lei do piso e equiparação salarial para agentes de saúde;
e) Cursos e capacitações constantes da Secretaria de Saúde.

A iniciativa Plano Estratégico de Desenvolvimento de Longo Prazo - Ceará 2050 tem o objetivo de traçar estratégias para acelerar o crescimento econômico estadual nas próximas três décadas e atender, de forma mais eficiente, às expectativas da sociedade pela oferta de serviços essenciais como a saúde, sob a coordenação da Universidade Federal do Ceará (UFC)

\footnotetext{
${ }^{24} \mathrm{O}$ número de leitos disponíveis no SUS e no Setor Privado apresentou comportamento semelhante, de 2008 para 2012, aumentou: leitos SUS de 15.735 para 16.151 e leitos privados de 3.416 para 4.606, e em 2016 reduziu: leitos SUS para 15.279 e leitos privados para 3.666 leitos, em decorrência do fechamento de vários hospitais no Estado, a exemplo do Hospital Maternidade Dr. Paulo Sarasate (133 leitos) em Caucaia; Hospital Regional Manuel de Abreu (97 leitos) e Casa de Saúde Santa Teresa (200 leitos), no Crato; Casa de Saúde Santo Inácio (119 leitos), em Juazeiro do Norte; Hospital Maternidade Dr. Almir Pinto (65 leitos), em Maranguape: Hospital Neurocentro (43 leitos), Hospital Aguanambi Gomes da Frota (150 leitos), Hospital Angeline (140 leitos) em Fortaleza COELHO, Vera Maria Câmara; LIMA, Arnaldo Ribeiro Costa. (org.) Ceará 2050: Juntos pensando o futuro. Estudo setorial especial. Fortaleza, 2018, p.35-37. Disponível em: <http://www.fastef.ufc.br/portal/wpcontent/uploads/2018/07/ESTUDO-SETORIAL-ESPECIAL-\%E2\%80\%93-SAUDE.pdf>. Acesso em: 02 jan 2019.

${ }^{25}$ Disponível em: <https://www.ceara.gov.br/projeto/ceara-saudavel/>. Acesso em: 02 jan 2019.

${ }^{26}$ Disponível em: <https://www.ceara.gov.br/projeto/ceara-saudavel/>. Acesso em: 02 jan 2019.
} 
e outros centros acadêmicos responsáveis por reunir as melhores contribuições regionais, nacionais e até internacionais para refletir sobre o que os cearenses desejam para $30 \operatorname{anos}^{27}$.

Em relatório setorial relativo ao setor da saúde, ressaltou-se que o rol das doenças crônicas não transmissíveis (DCNT), como as doenças do aparelho circulatório, câncer, obesidade, transtornos mentais, violência e acidentes, corresponderam em 2015, a mais de 68\% das causas de morte no Estado, e no Brasil a mais de 70\%, soma-se a isso a alta incidência de doenças infecciosas, como tuberculose, hanseníase, HIV/AIDS e arboviroses (dengue, zika e chicungunya) (COELHO; LIMA, 2018).

De tudo o que foi exposto, destaca-se o pioneirismo do Estado do Ceará no desenvolvimento de estratégias inovadoras na gestão da política de saúde pública, que o fazem ocupar papel de destaque no cenário nacional. Além disso, constatou-se a existência de uma série de normas e a necessidade de estudos técnicos para uma correta elaboração e aplicação da política de saúde no Estado, que deve passar por discussão e aprovação de União, Estados e Municípios, buscando uma maior integração e atuação conjunta para a regionalização do SUS.

A existência de uma hierarquia pré-definida, não se restringe à elaboração do planejamento em saúde, mas nas formas existentes de atendimento ao cidadão, devendo ser respeitadas as portas de entrada de atendimento do SUS. Contudo, alguns problemas como a redução do financiamento e dos leitos de UTI no Estado, bem como o envelhecimento da população também são preocupantes e constituem entraves para o desenvolvimento adequado da política do Sistema Único de Saúde no Estado do Ceará.

O presente estudo, contudo, se destina a tratar especificamente do outro problema enfrentado pela gestão estadual, a judicialização da saúde, que será tratada em tópico específico. Antes de se adentrar ao tema faz-se necessário realizar algumas considerações sobre a exigibilidade do serviço público de saúde adequado como um direito fundamental.

\footnotetext{
${ }^{27}$ Disponível em <https://www.ceara.gov.br/2018/02/05/consultores-do-ceara-2050-apresentam-diagnosticoqualitativo/>. Acesso em: 22 jan 2019.
} 


\section{DO DIREITO FUNDAMENTAL AO SERVIÇO PÚBLICO DE SAÚDE ADEQUADO E SUA EXIGIBILDADE}

Sustentando o serviço público de saúde adequado como um direito fundamental e considerando o cenário problemático de crescente judicialização de demandas individuais em saúde, pretende-se neste capítulo, por meio da compreensão da natureza dúplice do direito à saúde, fortalecer o entendimento do caráter objetivo do direito, que expende deveres objetivos ao Poder Público, devendo ser concentrados esforços no aprimoramento da sua prestação voluntária com foco nos seus procedimentos necessários e nas estruturas organizacionais em detrimento da judicialização indiscriminada.

Após apresentar o contexto e perspectivas da saúde no país, destaca-se algumas novidades lançadas pelo legislador em matéria de serviços públicos frente a sugestões da doutrina de medidas administrativas mais favoráveis à redução efetiva do excesso de demandas na área da saúde.

\subsection{Da noção de serviço público adequado}

A noção de serviço público, no mundo ocidental, se originou na França, no começo do séc. XX, quando se formou naquele país a Escola do Serviço Público, que teve como principais expoentes Duguit ${ }^{28}$ e Jèze ${ }^{29}$. A noção de serviço público adquiriu tanta força no ordenamento francês que passou a ser critério de direito administrativo e critério da competência da jurisdição administrativa (MEDAUAR, 2003).

\footnotetext{
${ }^{28}$ Léon Duguit confrontou a noção Alemã de Estado de Direito (puissance) com a ideia de um Estado de Direito Prestacional, traçando a Teoria dos Serviços Públicos, fortemente influenciada pela mudança da noção de soberania que o Estado sofreu no início do século XX, quanto se toma a consciência de que o Estado deve aos governados mais do que segurança interna e externa, daí sua conhecida noção de que o serviço público "é toda atividade cujo cumprimento é assegurado, regulado, e controlado pelos governantes por ser indispensável à realização da interdependência social e de tal natureza que não pode ser assumido senão pela intervenção da força governante". (DEGUIT, Léon. Traité de Droit Constitutionnel, $2^{\circ}$ ed., vol.II, Paris, Ancienne Librairie Fontemoing \& Cia. Éditeurs, 1923, p.55).

${ }^{29}$ Gaston Jéze atribui uma noção mais stricto sensu jurídica do que a sociológica de Duguit, deixando de definir os serviços públicos como atividades que devem ser asseguradas pelo Estado em razão da necessidade de manutenção dos liames sociais, para identificá-los como as atividades prestadas pelo Estado sob o regime jurídico de Direito Público: "Dizer que em determinada hipótese existe serviço público equivale a afirmar que os agentes públicos, para dar satisfação regular e contínua a certa categoria de necessidades de interesse geral, podem aplicar os procedimentos de direito público, isto é, um regime jurídico especial, e que as leis e regulamentos podem modificar a qualquer momento a organização do serviço público, sem que a isto se possa opor nenhum obstáculo insuperável de ordem jurídica". (JÉZE, Gaston. Principios Generales del Derecho Administrativo, vol.II, Buenos Aires, De Palma, 1948, p.4).
} 
A noção francesa tradicional de serviço público relacionava três aspectos enfatizados respectivamente dos conceitos: subjetivo (organização administrativa), objetivo (atividade de interesse geral) e formal (regime jurídico especial), funcionando como partes elementares de um conceito mais complexo: "Entendia-se por serviço público, a atividade de interesse geral prosseguida por um organismo administrativo sob um regime derrogatório de direito comum" (MELLO, 2017, p. 43).

A partir de 1921, acentuando-se nos anos e décadas seguintes, algumas situações prejudicaram a identificação de serviço público conforme a concepção da Escola do Serviço Público, pelo surgimento de elementos privados: tais como a gestão por particulares; serviços públicos realizado sob normas de direito privado; administração exercendo atividades industriais e comerciais, o que levou à chamada crise da noção do serviço público (MEDAUAR, 2003).

A noção permaneceu, contudo, a crise representou uma transformação da concepção de serviço público:

\begin{abstract}
Na França passou a ser admitida a gestão privada e a ser aceito o direito privado no regime jurídico do serviço público, emergindo ainda a categoria do serviço público industrial e comercial. E a noção foi deixando de ser critério de Direito Administrativo e da competência da jurisdição administrativa, embora mantenha raízes tão fortes, que hoje, se menciona, o serviço público a la française. Em outros países também se dissociou a noção de serviço público da gestão estatal e do exclusivo regime público (MEDAUAR, 2003, p. 117).
\end{abstract}

Na União Europeia não foi fácil estabelecer um critério geral para identificar o serviço público, devido à existência de países de tradições jurídicas não coincidentes (civil Law e common $l a w^{30}$ ). Enquanto parte deles havia solucionado as necessidades de serviços de sua coletividade, através da publicatio - declaração formal como serviço público de titularidade estatal e gestão direta ou indireta por concessionários; outros seguiram a via da simples regulação de atividades desenvolvidas por particulares (BEZERRA, 2008).

Chegou-se às noções de serviço de interesse geral; serviço de interesse econômico geral; serviço universal; e serviço público, simplesmente. Noções que, se nem sempre estão

\footnotetext{
${ }^{30} \mathrm{~A}$ concepção norte-americana, que retrata a ideia predominante nos países de common law, foi uma fonte de inspiração para preceitos constantes nos Tratados e outros textos da Comunidade Europeia. No modelo dos países de common law, as atividades que atendem às necessidades públicas devem ser providas de modo igual ao de qualquer outra atividade econômica, ou seja, por empresas privadas, que se sujeitam ao controle de agentes federais ou de agências de Estados-membros, para que se obtenha o resultado decorrente de uma conciliação entre o objetivo privado da maximização do lucro e o atendimento do interesse público, expresso no fornecimento de serviços adequados com tarifas moderadas (MEDAUAR, Odete. Serviços públicos e serviços públicos de interesse econômico geral. In: Uma avaliação das tendências contemporâneas do direito administrativo. MOREIRA NETO, Diogo de Figueiredo (Coord.). Rio de Janeiro: Renovar, 2003, p. 118).
} 
determinadas explicitamente nos tratados, fazendo parte do cotidiano das atividades e das instituições da União Europeia. Quanto ao conceito de serviço público, veja-se:

Serviço público - O termo serviço público brilha por sua ausência nos Tratados da União Européia. O novo Tratado de Funcionamento da União Européia - TFUE ${ }^{31}$, não define serviço público e, salvo uma única vez ${ }^{32}$, a ele não se refere explicitamente. Entretanto, no que diz respeito às instituições e às atividades da União, pode-se dizer que o termo vem sendo utilizado em um duplo sentido: umas vezes designando o organismo produtor do serviço e outras se referindo à missão de interesse geral que se confia ao organismo. Confunde-se com frequiência (sic), erroneamente, serviço público com setor público (incluída a função pública), isto é, missão e estatuto, destinatário e proprietário (BEZERRA, 2008, p. 120).

Mais adiante, comenta Helga Maria Sabóia Bezerra a respeito dos denominados "serviços de interesse econômico geral":

\begin{abstract}
Serviços de interesse econômico geral - É idéia (sic) especificamente comunitária que, embora não esteja definida nem nos Tratados nem no Direito derivado, aparece referida no TFUE nos artigos 14 (antigo art.16 TCE) e 106 (antigo art. 86 TCE).

Refere-se a atividades de serviço comercial que operam no mercado e às quais, por motivo de interesse geral, também são impostas, pelos Estados Membros, obrigações de serviço público (art. 14 e art. 106 TFUE). São os serviços prestados pelas grandes indústrias de rede como, por exemplo, os de energia elétrica e de comunicação, postais e de transportes. Estes serviços devem funcionar em conformidade com princípios e condições, econômicas e financeiras principalmente, que lhes possibilite cumprir suas finalidades (missão de interesse público).

São serviços que se produzem no âmbito do sistema econômico, não no sentido de que sejam ou não prestados com ânimo de lucro, senão no sentido de que o poder público tenha encomendado sua gestão, tornando obrigação legal sua prestação. $O$ Direito comunitário não os define a priori, nem se posiciona quanto à forma de gestão dos mesmos. Deixa a cada Estado Membro que determinem quais vão ser considerados, em seu Direito interno, os serviços de interesse econômico geral.

O que, sim, estabelece o TFUE, é um marco normativo para estes serviços, de maneira que as empresas gestoras dos mesmos estarão submetidas às normas referentes à livre concorrência, com a única exceção do art. 106.2 (antigo art. 86.2 TCE), segundo o qual estarão isentas de observar aquelas normas quando sua aplicação impeça de fato ou de direito o cumprimento da missão específica a elas confiada, o que é o caso dos monopólios naturais que, por sua própria essência, têm que estar subtraídos da livre concorrência. A exceção se justifica, já que há necessidades de interesse coletivo cujas condições de satisfação podem ser impedidas de realizar-se pelo livre jogo do mercado. (BEZERRA, p.121) (grifo nosso).
\end{abstract}

\footnotetext{
${ }^{31}$ Pelo Tratado de Lisboa (2007, com entrada em vigor em 2009), modificam-se o Tratado da União Europeia TUE e o Tratado Constitutivo da Comunidade Europeia - TCE, ganhando, este último, a denominação de Tratado de Funcionamento da União Europeia - TFUE (BEZERRA, Helga Maria Sabóia. As transformações da noção de serviço público na União Européia: o serviço de interesse geral do Tratado de Lisboa. Direito, Estado e Sociedade. Revista Eletrônica de Direito da PUC. Rio de Janeiro 32/131, jan.jun/2008, p. 121).

${ }^{32}$ Quando no Artigo 93 (antigo art. 73 TCE) estabelece que serão compatíveis com os Tratados as ajudas que respondam às necessidades de coordenação dos transportes ou que correspondam ao reembolso de determinadas obrigações inerentes à noção de serviço público. (BEZERRA, Helga Maria Sabóia. As transformações da noção de serviço público na União Européia: o serviço de interesse geral do Tratado de Lisboa. Direito, Estado e Sociedade. Revista Eletrônica de Direito da PUC. Rio de Janeiro 32/131, jan.jun/2008, p. 121).
} 
Para a autora BEZERRA (2008), a importância deste conceito consiste em que os serviços econômicos de interesse geral representariam o serviço público liberalizado, em sua nova formulação, depois da vitória da concorrência e da liberdade econômica, sendo considerado um pilar básico da cidadania europeia. A concepção francesa de serviço público teria sofrido uma redução, sendo reconhecido nos serviços de interesse geral do ordenamento jurídico europeu, que albergaria: "atividades de serviços não econômicos (como a escola obrigatória e a proteção social); funções soberanas e básicas do Estado (como segurança e justiça); os serviços de interesse econômico geral (como energia elétrica e telecomunicações)" (BEZERRA, 2008, p.131).

Mello (2017, p.59) destaca, que a seu ver a noção de serviço de interesse econômico geral:

[...] com a ressalva da possibilidade de realização em concorrência (e ainda sim nem sempre) e mesmo de serem exercidas por empresas privadas ainda quando não hajam sido previamente dados em concessão, não são outra coisa senão o próprio serviço público, já que no concernente ao regime de sua prestação se submetem às mesmas imposições jurídicas, pelo menos, às chamadas 'Leis de Rolland', as quais no Direito Francês são apontadas como substanciando os princípios fundamentais que os regem, a saber: mutabilidade, igualdade e continuidade.

No Brasil, as discussões travadas na Europa acarretaram questionamentos a respeito da persistência da noção de serviço Público. Para Mello (2017, p.62) seria absurdo falar no Brasil em "morte do serviço público", uma vez que a nossa Constituição atribui enorme relevo à expressão, mencionando-a não menos que 18 vezes $^{33}$, bem como mencionando os efeitos jurídicos que lhe são atribuídos.

Conceituando serviço público, do ponto de vista jurídico, como aquele que se consubstancia através de regime jurídico especial, instituído pelo Estado no interesse direto dos fins que consagrar como próprios, Mello (2017, p.63) ressalta que, ante o Direito, não seria uma qualidade própria da atividade que a enquadraria na noção de serviço público, mas seu regime normativo, conquanto seja certo que este lhe é atribuído, como regra quase geral, "ante o reconhecimento de que se trata de uma realidade socialmente identificada como relevante e cujo bom cumprimento demanda que seja assumida como Estado como pertinente a si próprio".

Medauar (2003) destaca que a Constituição Federal de 1988, diferencia serviço público de atividade econômica, ao determinar no art. 175 que "Incumbe ao Poder Público, na forma

\footnotetext{
${ }^{33} \mathrm{O}$ autor lista os seguintes dispositivos: "arts. 21 , XIV, 30, V, 34, VII, 'e', 35, III, 37, § $3^{\circ}$, I, 37, § 6 ' $^{\circ}$, I, 'a', $61, \S 1^{\circ}$, II, 'b', 136, § $1^{\circ}$, II, 139, IV, 145, II, 167, IV, 175, caput, 175, parágrafo único, I, 198, caput, 198, $2^{\circ}$, 202 , $\$ 5^{\circ}$, e 241, caput), sendo 5 delas reportadas a serviços públicos de saúde (arts. 34, VII, 'e', 35, III, 167, IV, 198, caput, 198, § $2^{\circ}$ ) além de outras 5 no Ato das Disposições Constitucionais Transitórias (arts. $2^{\circ}, \S 1^{\circ}, 66$, caput, 77, caput, 77, I, 'a', e 77, § 3 ${ }^{\circ}$ )" (MELLO, Celso Antônio Bandeira. Serviço público e concessão de serviço público. São Paulo: Malheiros, 2017, p.62).
} 
da lei, diretamente ou sob o regime de concessão ou permissão, sempre através de licitação, a prestação de serviços públicos", enquanto o art.173 atribui ao setor privado, precipuamente, a realização da atividade econômica: "Ressalvados os casos previstos nesta Constituição, a exploração direta da atividade econômica pelo Estado só será permitida quando necessária aos imperativos da segurança nacional ou a relevante interesse coletivo, conforme definido em $1 \mathrm{i}^{34, "}$.

Há certas prestações de atividade material, que por força da Constituição, são obrigatoriamente serviços públicos ${ }^{35}$, assim como outras obrigatoriamente não o são. São obrigatoriamente serviços públicos federais, embora não de titularidade exclusiva do Poder Público, os de saúde, de educação, de previdência social o os de assistência social:

É que, embora a Lei Magna os declare um "dever do Estado"(art.196 e 197 para a saúde, 205, 208, 211 e 213 para a educação, 201 e 202 para a previdência social e 203 e 204 para assistência social) afirma também, ou (a) que são livres à atividade privada" (art.199 para a saúde, art.209 para a educação, ou (b) expressamente contempla a presença de particulares no setor, independentemente de concessão ou permissão (art.204, I e II, para a assistência social), ou (c) pressupõe uma atuação 'complementar' da iniciativa privada (art. 202 para a previdência social; ou (d) impõe que o Estado os desempenhe e também os dê em concessão, já que supõe a complementariedade dos serviços privado, público e estatal (MELLO, 2017, p. 86).

\footnotetext{
${ }^{34}$ Alguns estudiosos passaram a incluir o serviço público na atividade econômica ou a considerá-lo atividade econômica. Para Eros Grau, "a atividade econômica em sentido amplo" abrangeria tanto a atuação do Estado em sentido estrito, intervenção do Estado na economia, como a prestação do serviço público, atuação de competência típica do ente público (GRAU, Eros Roberto. A ordem econômica na Constituição de 1988. 7. ed. São Paulo: Malheiros, 2002, p.141). Para Mello, a separação entre os dois campos - serviço público, como setor pertencente ao Estado, e o domínio econômico, como campo reservado aos particulares - é induvidosa e tem sido objeto de atenção doutrinária, notadamente para fins de separar empresas estatais prestadoras de serviço público das exploradoras de atividade econômica, ante a diversidade de seus regimes jurídicos. Tanto que o autor ressalta o fato do texto constitucional ao não definir o que sejam "atividades econômicas", deixar remanescente ao legislador margem de liberdade para qualificar outras atividades como serviço público, "desde que não ultrapasse as fronteiras constituídas pelas normas relativas à ordem econômica, as quais são garantidoras da livre iniciativa"(MELLO, Celso Antônio Bandeira. Serviço público e concessão de serviço público. São Paulo: Malheiros, 2017, p.720). Realmente, verifica-se que alguns preceitos contidos no art. 170 e destinados a nortear a atividade econômica não se aplicam ao serviço público, a livre iniciativa, é um exemplo, pois não se pode dizer que a prestação dos serviços públicos é informada pela livre iniciativa, tendo em vista que decisão de transferir a execução ao setor privado é sempre do poder público. Também impensável aplicar ao serviço público o preceito do parágrafo único do art. 170 (possibilidade de condicionamento do exercício da atividade econômica a prévia autorização administrativa), porquanto todos os serviços públicos prestados por particulares devem sê-lo mediante titulação, na qual está subtendido o consentimento do Poder Público (MEDAUAR, Odete. Serviços públicos e serviços públicos de interesse econômico geral. In Uma avaliação das tendências contemporâneas do direito administrativo. MOREIRA NETO, Diogo de Figueiredo (Coord.). Rio de Janeiro: Renovar, 2003, p. 125).

${ }^{35}$ São obrigatoriamente públicos os serviços que a Lei Magna declarou competirem ao Poder Público. Assim, serão públicos federais os arrolados como de competência da União no art.21, X (serviço postal e correio aéreo nacional), XI (serviços de telecomunicações), XII, 'a' (serviços de radiofusão sonora, isto é, rádio e de sons e imagens - ou seja, televisão), XII, 'b' (serviços e instalações de energia elétrica e aproveitamento energético dos cursos d'água), XII, 'c' (navegação aérea, aeroespacial e infraestrutura portuária), XII, 'd'(serviços de transporte ferroviário e aquaviário entre portos brasileiros e fronteiras nacionais ou que transponham os limites de mais de um Estado ou Território), XII, 'e' (serviços de transporte rodoviário interestadual e internacional de passageiros), e XII, 'f' (a prestação dos serviços portuários marítimos, fluviais e lacustres) (MELLO, Celso Antônio Bandeira. Serviço público e concessão de serviço público. São Paulo: Malheiros, 2017, p.88).
} 
Portanto, o serviço público não tem o condão de satisfazer a toda e qualquer necessidade material, mas somente aquelas que pelo relevo que lhes atribui, o Estado considera de seu dever assumi-las a si próprio (mesmo que sem exclusividade). Ficando todos eles submetidos a um tratamento normativo mais estrito do que o aplicável ao conjunto de atividades privadas, pois, dada a grande relevância social que possuem o Poder Público os disciplina com um rigor especial, com disciplina de direito público (MELLO, 2017).

$\mathrm{O}$ atendimento da necessidade a ser obtido mediante o serviço público deverá ainda obedecer a uma forma específica, pois além de possuir um regime jurídico geral, onde estão esculpidas as regras gerais aplicáveis a todos os serviços públicos (p.ex. a disciplina constitucional e a Lei 8.987/95), haverá também um regime jurídico especial para cada serviço público (GARCIA FILHO, 2003).

No atinente especificamente à prestação dos serviços públicos de saúde, Mapelly Júnior (2017, p.47) destaca que:

A conceituação de políticas públicas no contexto das instituições, notadamente com a
percepção de que elas não surgem da mera discricionariedade do gestor público, ainda
que ele detenha certa liberdade de escolha de prioridades, mas sim de uma ideia-
diretriz que precisa ser organizada pelo direito, de forma a se institucionalizar como
política de estado (não de um determinado governo), com efetividade em escala na
sociedade (regime de efeitos), permanência no tempo e aceitação do meio social, onde
a ideia se espalha e se fortalece com o passar do tempo, permite compreender melhor
o desenho jurídico do Sistema Único de Saúde (SUS) que, como um conjunto
articulado e contínuo de ações e serviços públicos de saúde (art.198, caput, CF), foi
formatado em um regime jurídico específico.

As inúmeras políticas que integram o Sistema Único de Saúde (SUS), que abrangem ações e serviços públicos de saúde, têm um desenho institucional formado em atos normativos, de conteúdo organizacional e sistemático, devendo o arranjo constitucional (institucional) e infraconstitucional das políticas públicas de saúde do SUS ser respeitado.

Mapelly Júnior (2017) destaca que o arranjo constitucional (institucional) das políticas públicas de saúde do SUS, é determinado por um corpo normativo básico, constituído pelos seguintes diplomas legais:

a) a Constituição Federal de 1988 (art.6º e arts. 196 a 200), que, em caráter superior e central define princípios, diretrizes e algumas regras específicas que devem parametrizar a saúde pública; b) a Lei $\mathrm{n}^{\circ}$ 8.080, de 19 de setembro de 1990, conhecida como Lei Orgânica da Saúde (LOS), que regulamenta, em todo o território nacional, 'as ações e serviços de saúde, executados isolada e conjuntamente, em caráter permanente ou eventual, por pessoas naturais ou jurídicas de direito público ou privado'( $\operatorname{art.1}^{\circ}$ ); c) a Lei $n^{\circ} 8.142$, de 28 de dezembro de 1990, que complementa a anterior para dispor sobre a participação da comunidade no SUS, as Conferências e os Conselhos de Saúde, bem como, as transferências intergovernamentais de recursos nos fundos de saúde; d) a Lei $\mathrm{n}^{\circ}$ 12.401, de 28 de abril de 2011, que alterou dispositivos da LOS para dar status 
de lei aos foros de pactuação e negociação conhecidos como Comissão Intergestores Tripartite (CIT) e Comissão Intergestores Bipartite (CIB), bem como, o Conselho Nacional de Secretários de Saúde (CONASS) e o Conselho Nacional de Secretarias Municipais de Saúde (CONASEMS); f) o Decreto $\mathrm{n}^{\circ}$ 7.508, de 28 de junho de 2011, que regulamenta a LOS no que diz respeito à Organização do SUS, ao Planejamento da Saúde, à Assistência à Saúde e à Articulação Interfederativa; g) a Lei Complementar $n^{\circ} 141$, de 13 de janeiro de 2012, que normatiza os recursos sanitários e os critérios de rateio interfederativo; e h) normas administrativas complementares, destacando-se, para este estudo, a Portaria MS 3.916, de 30 de outubro de 1998 (Política Nacional de Medicamentos) e a Resolução CNS 338, de 6 de maio de 2004 (Política Nacional de Assistência Farmacêutica) (MAPELLY JÚNIOR,2017, p.51).

A Lei Orgânica da Saúde $n^{\circ}$ 8.080/90, em seu art. $7^{\circ}$, dispõe que tanto as ações e serviços públicos de saúde executados diretamente pelo poder público, como aqueles executados por meio de terceiros (serviços contratados ou conveniados), serão desenvolvidos de acordo com as diretrizes e os princípios da Constituição.

Alguns estudiosos sustentam a existência de um direito fundamental de acesso aos serviços públicos. Sobre o tema ainda não há um consenso, pois, certos autores, apesar de aceitarem os serviços públicos como instrumentos cruciais à promoção dos direitos sociais, negam a existência de um direito fundamental de acesso aos serviços públicos (HACHEM, 2014). Situam-se entre eles, Alexandre Santos de Aragão (2011), ao afirmar que não existe um direito fundamental de acesso aos serviços públicos, reconhecendo, outrossim, que os serviços públicos são indispensáveis ao exercício de alguns direitos fundamentais.

Para Finger (2003, p.80) os serviços públicos exercem função instrumental em relação aos direitos fundamentais, contudo, a mesma autora reconhece que a doutrina administrativista tem se encaminhado no sentido de reconhecer o direito ao serviço adequado, previsto no art.175, inciso IV, como o "direito de exigir do Estado a realização de prestações positivas, para a satisfação de necessidades reputadas essenciais para os indivíduos ou para a coletividade".

Para Hachem (2014, p.83-84), o direito fundamental ao serviço público adequado consiste em um direito materialmente fundamental por quatro motivos:

(i) está subtendido no art. $6^{\circ}$, uma vez que não há como se assegurar o acesso de todos os titulares dos direitos sociais ali previstos sem que o Estado preste serviços públicos (não se atinge os fins se não se tem os meios); (ii) radica-se em uma posição jurídica que consta do art. 175, parágrafo único, IV da Constituição, pois se ao Poder Público incumbe a 'obrigação de manter o serviço adequado', em contrapartida o cidadão tem o direito de recebê-lo, e seu conteúdo e importância se aproximam intimamente ao teor dos direitos sociais do $\operatorname{art}^{\circ} 6^{\circ}$, eis que sem a prestação de serviços públicos adequados eles se tornariam letra morta; (iii) está previsto expressamente no Protocolo Adicional à Convenção Americana Sobre Direitos Humanos em Matéria de Direitos Econômicos, Sociais e Culturais ('Protocolo de San Salvador'), na Declaração Americana de Direitos e Deveres do Homem, na Declaração Universal dos Direitos Humanos, na Convenção Sobre a Eliminação de Todas as Formas de Discriminação contra a Mulher, entre outros; (iv) decorre diretamente dos princípios da dignidade da pessoa humana e da cidadania (art. $1^{\circ}$, I e II da $\mathrm{CF}$ ), pois os serviços públicos são 
indispensáveis para proporcionar aos cidadãos condições de existência digna e possibilitar sua participação ativa na comunidade política e social, além de serem imprescindíveis para atingir os objetivos fundamentais da República, de erradicar a pobreza, reduzir as desigualdades sociais, garantir o desenvolvimento e construir uma sociedade livre, justa e solidária (art.3ํ, I a III, CF) (HACHEM, 2014, p.83).

Tratando do conteúdo jurídico do direito fundamental ao serviço público adequado, Hachem (2014, p.86) sustenta que é condição necessária que esse serviço se assente sobre o regime de Direito Público, composto tanto pelo núcleo principiológico comum de matriz constitucional (princípios da legalidade, publicidade, moralidade, impessoalidade, eficiência, segurança jurídica, proteção à confiança legítima, boa-fé, razoabilidade, proporcionalidade, motivação, entre outros), quanto por um conjunto de princípios jurídicos específicos (como os descritos no art. $6^{\circ}, \S^{\circ}$ da Lei $n^{\circ} 8.987 / 95$, que fixa parâmetros mínimos para a prestação do serviço adequado: regularidade, segurança, atualidade, generalidade, cortesia na prestação e modicidade das tarifas).

A existência do direito fundamental ao serviço público adequado pode ser entendida como um desdobramento da obrigação do Estado Democrático em garantir o direito fundamental à boa administração pública. Juarez de Freitas define o direito fundamental à boa administração pública como o:

[...] direito fundamental à administração pública eficiente e eficaz, proporcional cumpridora de seus deveres, com transparência, sustentabilidade, motivação proporcional, imparcialidade e respeito à moralidade, à participação social e à plena responsabilidade por suas condutas omissivas e comissivas (FREITAS, 2014, p.21).

Diante de seu conceito, o autor destaca uma noção juridicamente refinada de políticas públicas, como as "políticas constitucionais de Estado, que o governo precisa em tempo hábil, agendar e implementar, mediante programas eficientes, eficazes e justificados intertemporalmente, em conjunto com outros atores políticos”. Esses programas devem ser enunciados e implementados de acordo com prioridades constitucionais cogentes, sob pena de omissão específica lesiva do Poder Público (FREITAS, 2014, p. 32).

$\mathrm{O}$ direito fundamental à boa administração pública, assimilado com rigor, favorece a releitura da responsabilidade do Estado, notadamente para combater, além dos excessos da discricionariedade, a omissão inconstitucional, isto é, a falta do exercício de competências discricionárias. É fato que, a discricionariedade administrativa pode resultar contaminada por abusividade (arbitrariedade por excesso) ou por inoperância (arbitrariedade por omissão), no tocante à materialização das prioridades constitucionais relevantes, em ambos os casos haveria violação ao princípio da proporcionalidade (FREITAS, 2014). 
O descumprimento deste princípio também acarretaria a sindicabilidade do serviço e a consequente responsabilização do Estado. Para ilustrar as possíveis derivações do princípio da proporcionalidade, o autor cita afirma que:

[...] (f) É proporcional a responsabilidade por danos morais causados pela demora anômala e irrazoável de prestação de atendimento médico que gera prejuízo à saúde. [...] (h) É proporcional determinar judicialmente ao município que amplie e melhore o atendimento em hospital de sua alçada, sem que se consinta a persistência de omissão transgressora da carta, com vedação de invocar a fórmula da reserva do possível para se evadir do cumprimento de prestação cogente, relacionada à saúde (CF, arts. 196 e 197).

(i) É proporcional afirmar o direito a medicamento de uso contínuo, oponível ao Poder Público, com os devidos cuidados para evitar favorecer mercado secundário ou outros desvios. Até o bloqueio de contas públicas pode ser excepcionalmente autorizado pelo Poder Judiciário. E o descumprimento desse dever de boa administração, ao acarretar a morte do paciente ou o agravamento de seu quadro, revela-se apto a ensejar o dever indenizatório. [...] (FREITAS, 2014, p.85).

Conclui-se pela sindicabilidade judicial do serviço público de saúde adequado, que pode ser realizada também pela via principio lógico, contudo, nem toda prestação poderá ser considerada objeto de serviço público, somente aquela que o Estado se obriga a cumprir dentro dos parâmetros da Política Pública universalmente planejada.

Além disso, impende ressaltar que para se alcançar o serviço de saúde adequado, a via judicial deveria ser a última alternativa. Num cenário de crescente judicialização, faz-se necessário fortalecer o entendimento do caráter objetivo do direito à saúde, que expende deveres objetivos ao Poder Público, devendo, sim ser concentrados esforços no aprimoramento da prestação desse serviço, com foco nos seus procedimentos necessários e nas estruturas organizacionais.

No próximo subtópico, busca-se tratar sobre a discussão a respeito da titularidade propriamente dita dos direitos sociais, em particular do direito à saúde, para entender um pouco mais sobre a dimensão objetiva desse direito.

\subsection{Da dupla dimensão do direito à saúde e sua relevância no campo da exigibilidade dos direitos sociais}

A problemática relativa a este tema pode ser ilustrada com base na indagação de Daniel Hachem (2013) quando questiona se a Constituição, ao prever direitos fundamentais sociais, conferiria sua titularidade aos cidadãos de forma individual, permitindo a cada um exigir de maneira isolada a tutela administrativa e/ ou judicial do bem jurídico em questão, ou de forma transindividual, possibilitando a reivindicação dessa proteção somente pela via coletiva. 
Essa reflexão deve considerar a estrutura normativa bidimensional dos direitos fundamentais, que além de conferirem posições subjetivas ao cidadão no marco de uma relação jurídica com o Estado, expendem deveres objetivos ao Poder Público, obrigando-o a proporcionar condições de exercício e de proteção de tais direitos, independentemente de provocação do particular (HACHEM, 2013)

Quanto à segunda perspectiva, entende o autor que a discussão precisa avançar, sugerindo que se deixe de lado a querela reducionista sobre a possibilidade de associar direitos sociais à condição de direitos subjetivos, para em vez disso, observar em que medida esse duplo caráter - subjetivo e objetivo - dos direitos fundamentais influencia na questão da sua titularidade individual ou transindividual (HACHEM, 2013).

Da interpretação sistemática dos enunciados constitucionais que versam sobre o direito à saúde nasce um direito fundamental, em sentido amplo, que, se visto como todo, congrega diversas pretensões jurídicas jusfundamentais com diferentes funções:

(i) a liberdade de escolher as práticas diagnósticas, os métodos terapêuticos e os medicamentos que o titular do direito irá utilizar, restando vedada qualquer imposição estatal nesse sentido (função de defesa); (ii) o fornecimento de serviços médicos ambulatoriais ao cidadão (função de prestação fática); (iii) a criação de órgãos e pessoas jurídicas, como postos de saúde e hospitais públicos, bem estruturados para o atendimento da população em geral (função de organização); (iv) a elaboração de normas administrativas que regulamentem os requisitos para a distribuição gratuita de medicamentos pelo Estado, inclusive com a confecção das listas de medicamentos que integram o componente básico da Assistência Farmacêutica (função de procedimento); (v) a definição de uma política de vigilância sanitária, que fixe normas proibitivas à comercialização de produtos e insumos que possam causar risco à saúde, fiscalizando a sua regular observância pelos particulares (função de proteção) (HACHEM, 2013, p.628).

Para Hachem (2013), a grande problemática está no fato de que, muitas vezes, alude-se ao direito fundamental como um todo (sentido amplo) para se discutir se é possível exigi-lo judicialmente ou não. Faz-se uma menção genérica do direito sem demonstrar quais são as posições de direitos fundamentais (direito fundamental em sentido estrito) que estão englobadas pela norma jusfundamental em questão. Sendo necessário, portanto, diferenciar as dimensões subjetiva e objetiva dos direitos fundamentais, como pressuposto para verificar a questão relativa à titularidade (individual ou transindividual) desses direitos, e suas possíveis formas de tutela.

Não é o direito, no caso à saúde, que será individual, coletivo ou difuso, mas sim a pretensão jurídica invocada numa situação determinada. Um mesmo direito pode então invocar inúmeras pretensões jurídicas distintas, titularizadas: por um único indivíduo; por grupos, classes e categorias determinadas (ou determináveis); ou por toda uma coletividade 
indistintamente considerada. Sustenta o autor que, em cada caso, será crucial verificar se o mais indicado é a satisfação pontual da pretensão individualizada ou se o ideal será a determinação de uma ação administrativa coletiva que resolva, de uma só vez, as carências de múltiplos titulares de direitos fundamentais sociais que se encontram em idêntica situação (HACHEM, 2013).

Sarlet (2013), em estudo sobre o problema da titularidade do direito social à saúde, analisa alguns argumentos que sustentam que a concessão, pela via judicial, de prestações de caráter individual ou para determinados grupos constituem via ilegítima de efetivação do direito à saúde. Uma dessas linhas argumentativas advoga que os direitos sociais são direitos de titularidade coletiva (transindividual) e não permitiriam, por sua natureza, uma objetivação individual, mormente para o efeito de serem deduzidas judicialmente. Outra delas vislumbra na tutela judicial individual uma violação ao princípio da isonomia, argumentando, dentre outras razões, que tal sistemática acabaria privilegiando apenas parcela da população, notadamente aquela que dispõe da informação e dos recursos suficientes para buscar o acesso ao sistema judiciário.

Quanto ao primeiro argumento colacionado, Sarlet (2013) lembra que tal questão foi objeto de detida análise, resultando na suportada pela jurisprudência atualmente dominante no STF, de que a titularidade dos direitos sociais e do direito à saúde em particular é tanto individual quanto coletiva e mesmo difusa. Quanto à segunda proposição, o autor sustenta que o respeito à isonomia não pode servir de argumento para eventual violação da dignidade concreta de cada indivíduo, ainda mais quando o impacto negativo em relação a terceiros (não beneficiados pela tutela individual ou não-integrantes do grupo beneficiado), consistente, na maior parte das vezes e segundo a argumentação habitualmente deduzida, na possível inexistência de recursos para atendimento de outras demandas, na maior parte dos casos não é objeto de demonstração plausível.

Essa linha argumentativa exige diálogo com outros fundamentos, como é o caso da delimitação do objeto do direito à saúde (quais prestações devem ser garantidas pelo Estado ao particular) bem como da discussão em torno da aplicação do princípio da subsidiariedade, de acordo com o qual o acesso ao sistema público de saúde deve ser reservado a quem não mantém um adequado plano de saúde privado e de assegurar com seus próprios recursos (ou de terceiros que tenham um dever de sustento) prestações necessárias à salvaguarda de uma vida digna (SARLET, 2013).

Ao tratar do tema do princípio da universalidade de acesso aos serviços públicos, Hachem (2014) sustenta que a Administração Pública tem o poder de ofertar um serviço 
negando-o para determinados cidadãos, excluindo o seu acesso por determinados motivos e fazendo algumas espécies de distinção, desde que isso se mostre necessário para que o fornecimento seja efetivamente universal e desde que a feição material do princípio da igualdade reclame a adoção de um critério diferenciado na prestação.

Na mesma linha, Dinorá Musseti Grotti (apud HACHEM, 2014, p. 91) entende que:

[...] a prestação do serviço deve ser igual para aqueles que se encontrem em condições comparáveis, respeitadas as distinções de suas condições, que conduzam eventuais diferenças de cuidados. Qualquer discriminação deve ser justificada em função da condição ou situação em que objetivamente cada usuário se encontra.

Para a prestação do direito fundamental mediante o serviço público, não deveria ser desconsiderada a capacidade econômica do cidadão, uma vez que o objetivo dos direitos sociais é alcançar a igualdade material, não podendo ser proporcionado na mesma medida a todos indiscriminadamente, sob pena de não estar se concretizando essa isonomia. Conforme palavras do referido autor, cumpriria a administração "tratar desigualmente as situações desiguais, na medida de suas desigualdades, em observância ao princípio da igualdade material ${ }^{36}$ ", (HACHEM, 2014, p. 94).

Sustenta-se que a universalidade do acesso aos serviços públicos de saúde impõe a garantia de que ele seja oferecido a todos os que dele necessitarem, mas não significa que todos podem fruí-lo exatamente da mesma forma, sendo possível a cobrança pautada no critério do poder aquisitivo e da capacidade econômica do cidadão. A base jurídico-constitucional para essa afirmação se encontraria tanto na ausência de previsão expressa da gratuidade como diretriz do Sistema Único de Saúde ${ }^{37}$, como a derivaria de uma das concepções de justiça social que é agasalhada pela Constituição Brasileira de 1988 (HACHEM, 2014).

A questão da gratuidade das ações e serviços de saúde, no ano de 2014, foi objeto de debate no STF. A polêmica se deu em torno da chamada diferença de classe, uma proposta para

\footnotetext{
${ }^{36} \mathrm{O}$ autor aponta que a universalidade dos direitos fundamentais sociais como a saúde e a educação, no tocante à sua função prestacional, deve ser encarada como um ponto de chegada: "embora nem todos possam, de partida, exigir as respectivas prestações estatais positivas gratuitamente, já que alguns não necessitam delas e podem obtêlas de outras formas ou pagar por elas, esses direitos são universais como um ponto de chegada, porque a sua previsão pressupõe que todos ascendam através deles, com ou sem o auxílio do Estado, o conjunto valorativo que compõe a moralidade básica dos direitos humanos (dignidade, liberdade, igualdade, etc.). Do contrário, se a sua função prestacional for atribuída identicamente a todos, o que ocorre é que eles, por estarem sendo "concebidos como direitos universais desde o ponto de partida, não conseguem manter a universalidade no ponto de chegada". (HACHEM, Daniel Wunder. Direito fundamental ao serviço público adequado e capacidade econômica do cidadão: repensando a universalidade do acesso à luz da igualdade material. A\&C - Revista de Direito Administrativo \& Constitucional, Belo Horizonte, ano 14, n. 55, p. 123-158, jan./mar. 2014, p. 101).

${ }^{37}$ Do ponto de vista constitucional, não haveria vedação à cobrança pelos serviços de saúde.
} 
que pacientes do Sistema Único de Saúde (SUS) pudessem pagar para ter melhores acomodações.

Em audiência pública convocada pelo STF, para debater o tema, objeto do Recurso Extraordinário $\mathrm{n}^{\circ}$ 581.488/RS, interposto pelo Conselho Regional de Medicina do Estado do Rio Grande do Sul (Cremers) contra decisão da Justiça Federal da $4^{\mathrm{a}}$ Região, desfavorável à sua pretensão de restabelecer a prática, Dra. Maria do Socorro de Souza, Presidente do Conselho Nacional de Saúde, sustentou que a gratuidade das ações de saúde decorreria do princípio da solidariedade que segmenta a saúde, na concepção constitucional de seguridade social:

\begin{abstract}
Nós, sociedade, já pagamos pelo SUS com nossas contribuições, de forma direta e de forma indireta. Então, para nós, essa lógica de pagar para além do que o Estado arrecada e deve redistribuir, pagar diretamente ao médico ou ao hospital, seria pagar duas vezes por um direito que nós temos garantido na nossa Constituição. O SUS tem que ser compreendido e reafirmado nesta Casa como uma política social de relevância, e de relevância pública, segundo exatamente o que determina a Constituição Federal no seu artigo 197, e é financiada por toda a sociedade, ou seja, todos nós já financiamos o SUS. (STF, online, 2014)
\end{abstract}

O presidente do CONASS, Dr. Wilson Duarte Alecrim, na mesma audiência, defendeu que a legislação pátria não deveria admitir a "diferença de classe" por esta ser contrária aos princípios constitucionais de acesso universal, integralidade e isonomia. Manifestou que o CONASS seria contrário ao copagamento, pois o modelo organizativo do sistema público de saúde teria na lei, de forma expressa e inequívoca, a gratuidade das ações e serviços de saúde ofertados à população:

Aqueles que, para defender a "diferença de classe", consideram de importância a
ausência dos termos gratuidade ou gratuito na descrição dos artigos 196 a 200 da
Constituição, cabe indicar que a Lei Complementar $\mathrm{n}^{\circ} 141$, em seu artigo $2^{\circ}$,
estabeleceu que somente podem ser consideradas como despesas as ações de serviços
públicos de saúde que sejam de acesso universal e gratuito. Ao apresentar
expressamente o termo gratuito, a lei proíbe o copagamento dentro do sistema. Da
mesma forma, isso já estava estabelecido na Lei no 8.080 . Consequentemente, estando
a Administração Pública submetida ao artigo 37 da Constituição Federal, vinculada
ao Princípio da Legalidade em toda a sua atividade, não pode o administrador incorrer
em qualquer desvio ou afastamento da gratuidade das ações de serviço do SUS; ao
administrador, só é permitido o que está na lei, e não há lei que permita a diferenciação
de classe (STF, online, 2014).

O ministro relator Dias Toffoli, que negou seguimento ao recurso, considerou o sistema de custeio da seguridade social, nele incluso o sistema único, que estabelece no art. 195 da Constituição que a "Seguridade Social será financiada por toda a sociedade, de forma direta e indireta, nos termos da lei, mediante recursos provenientes dos orçamentos da União, dos Estados, do Distrito Federal e dos Municípios”, o que deve ser realizado de forma proporcional e equânime. Considerando que o espírito que permeia e rege todo o sistema é o da cooperação, 
da solidariedade e da atuação no sentido de redução de desigualdades sociais, buscando-se conferir a todos idênticas oportunidades de acesso aos benefícios, resultaria extremamente incoerente pretender instituir um procedimento que promovesse a exclusão, segregação e diferenciação com base em fatores unicamente econômicos ${ }^{38}$.

No tocante à possibilidade de utilização de serviços diferenciados por pagamento da "diferença de classe" no SUS, Avelãs Nunes sustenta que se trata de "autêntica privatização disfarçada", que permite que seguradoras que exploram os seguros de saúde pressionem os médicos que trabalham para elas, no sentido de internarem os seus segurados em hospitais do SUS, mediante o pagamento da "diferença de classe" para que possam estar comodamente instalados, sendo todo o resto pago com dinheiro público, o que assegura imenso lucro às operadoras (NUNES; SCAFF, 2011).

Adotando posição contrária à cobrança dos serviços de saúde, Avelãs Nunes sustenta que a diferenciação de rendimento entre as pessoas e os diversos grupos sociais deve se refletir apenas na definição do sistema fiscal e de contribuição para as receitas do Estado e não prestação dos serviços públicos (NUNES; SCAFF, 2011).

Referido autor destaca que existe um enviesamento na filosofia do serviço público de saúde, quando a interpretação que é feita da CF/88 não deixa claro que o sistema de saúde deva ser "gratuito para todos", o mesmo ocorreu com a Constituição da República Portuguesa de 1976. Quando essa interpretação passa a tratar a saúde como parte da política de "caridade pública", na qual a gratuidade seria reservada apenas para os mais pobres, perdendo-se a qualidade de serviço público "geral, universal e gratuito para todos", o acesso a esses serviços passa por uma degradação, pela carência de investimentos (NUNES; SCAFF, 2011).

Com efeito, o princípio da gratuidade no SUS, apesar de não estar referido de maneira expressa na Constituição Federal, é aceito como um princípio implícito de nossa Lei Maior, eis que apesar de a Constituição de 1988 não fazer referência expressa à gratuidade, estabelece que saúde é "[...] direito de todos e dever do Estado" (CF, art. 196). Por ser um dever do Estado, de acesso universal e igualitário, as ações de saúde prestadas pelo SUS devem ser gratuitas. Assinale-se ainda, que a gratuidade da prestação do serviço de saúde está expressa na Lei Orgânica da Saúde, Lei no 8.080/1990, art. 43: “[...] a gratuidade das ações e serviços de saúde fica preservada nos serviços públicos contratados, ressalvando-se as cláusulas dos contratos ou convênios estabelecidos com as entidades privadas".

\footnotetext{
${ }^{38}$ Recurso Extraordinário $\quad \mathrm{n}^{\mathrm{o}} \quad 581.488 / \mathrm{RS}$ Disponível em: http://redir.stf.jus.br/paginadorpub/paginador.jsp?docTP=TP\&docID=10624184 Acesso em: 20 fev 2018.
} 
Conforme ressaltam Nelson Nery e Rosa Nery, apud Dallari (2010, p.750) “[...] no Estado democrático de Direito, a realização dos direitos sociais, econômicos e culturais tem seu suporte financeiro nos impostos, e.g., ensino básico gratuito, serviços de saúde etc.”. Portanto, seria o Estado o responsável por garantir os meios para a realização das prestações idealizadas nas prestações e serviços de saúde, direito social que tem como finalidade atingir a igualdade e tais prestações já são financiadas por toda a coletividade.

Ao tratar do argumento da capacidade econômica, Sarlet (2013, p. 167) alerta ainda, para o fato de que, na seara da saúde, existem prestações tão dispendiosas que mesmo pessoas de alto padrão aquisitivo não poderiam custeá-las pessoalmente, além do fato de que nem sempre, especialmente no caso dos medicamentos, as prestações são cobertas pelos planos privados de saúde.

O mais importante quanto a este tema é que eventuais excessos sejam contidos e critérios mais racionais e isonômicos devam ser desenvolvidos, não só no que tange à prestação do serviço de saúde, mas inclusive à sua judicialização. Sarlet (2013, p. 168) revela o receio de que o simples afastamento ou mesmo uma forte limitação das demandas individuais possa representar uma violação também do direito-garantia de acesso à justiça (inafastabilidade judicial). O certo é que, se se afigura raro o Poder Judiciário indeferir uma demanda de saúde com base na capacidade econômica da parte, mais custoso ainda seria à própria Administração aferir, caso a caso, a possibilidade ou não de conceder determinada prestação de acordo com a mesma capacidade.

Retomando o tema da titularidade dos direitos sociais, em particular o da saúde, vê-se que a CF de 1988 expressamente a atribuiu a toda e qualquer pessoa, independentemente de sua nacionalidade ou de seu vínculo de maior ou menor permanência com o Brasil, de acordo com o disposto no art. 196, "a saúde é direito de todos e dever do Estado". De outra parte, como sustenta Sarlet (2013, p.155), a "utilização do termo 'todos', não constitui indicativo de que a titularidade será necessariamente coletiva (transindividual), ainda mais no sentido de uma exclusão da titularidade individual".

Com a ênfase nos direitos sociais, como direitos de cunho eminentemente prestacionais através dos quais pode-se atingir a igualdade material, passou-se a se defender de sobremaneira os interesses individuais como garantia de atingir o interesse público. Nessa dimensão, a defesa dos direitos coletivos não pode se colocar na posição de óbice para atingir os direitos individuais, os coletivos existem como políticas públicas, como forma de assegurar materialmente esses direitos individuais, mas o direito coletivo constitui um meio e não a finalidade última do Estado, que é assegurar a dignidade individual. 
No caso do direito à saúde, entende-se que sua proteção individual por meio de prestação material, não deve ser aplicada a toda e qualquer demanda, sem qualquer tipo de distinção, o que facilita neste caso, a convivência necessária da perspectiva individual com sua dimensão coletiva. Claro que houve uma mudança de entendimento quanto à supremacia do interesse público versus interesse individual, devendo-se em tese aplicar-se a primazia do direito individual, mas até que ponto o direito individual pode se sobrepor ao da coletividade?

Mapelly Júnior (2017) destaca que no Estado de São Paulo, as demandas judiciais para o fornecimento de medicamentos, por exemplo, aumentaram consideravelmente, sendo que, no ano de 2016:

a Secretaria de Estado da Saúde de São Paulo (SES/SP) gastou 65 milhões de reais para cumprir decisões judiciais somente da comarca da capital, referentes a 3.600 pessoas supostamente beneficiadas. Ao mesmo tempo, gastou-se o total de 838 milhões de reais para o atendimento de 380 mil pessoas inscritas no programa de medicamentos excepcionais. Nesse mesmo ano foram gastos 18 mil reais por paciente de ação judicial, aproximadamente, enquanto o programa de medicamentos de Dispensação Excepcional consumiu 2,2 mil reais por paciente (MAPELLY JUNIOR, 2017, p.21).

De acordo com esses e outros dados ${ }^{39}$ fica cada vez mais demonstrado que muitas das decisões judiciais infringem ou distorcem princípios do SUS, sobretudo o da equidade.

Ao questionar a existência do princípio da Supremacia do Interesse Público, Daniel Sarmento (2012) esboça uma proposta alternativa para a solução das colisões entre interesses públicos (da coletividade) e direitos fundamentais no direito brasileiro, discussão que pode ser bem proveitosa quando se tenta entender a relação entre direitos individual e direito a saúde de forma coletiva.

Do ponto de vista moral, a afirmação da supremacia do interesse da coletividade sobre os direitos pertencentes a cada um dos seus componentes poderia ser justificada a partir de duas

\footnotetext{
${ }^{39}$ Fernanda Vargas Terrazas sustenta que os direitos sociais são direitos essencialmente coletivos e que sua garantia de forma individualizada - o que ocorre normalmente quando há atuação do Poder Judiciário - resulta em tratamento diferenciado. Sustenta ainda que, essa diferenciação não é feita em benefício das pessoas que não possuem voz política, mas sim, daquelas já consideradas no processo político. Após captura e cruzamento de uma série de dados das pessoas atendidas no FAJ (Fornecimento para Ação Judicial), da Secretaria de Saúde do Estado de São Paulo (SES/SP), estrutura física organizada para a entrega mensal de medicamentos determinados pela justiça aos litigantes em processos judiciais, verificou-se que $97 \%$ dos entrevistados embasaram seus pleitos judiciais a partir da prescrição de médico particular. Dentre os entrevistados, $89 \%$ disseram ter sido orientados pelo próprio médico a promover ação judicial reclamando a dispensação de medicamento não padronizado pelo SUS. Ainda, $62 \%$ das demandas foram conduzidas por advogado particular. Por fim, $96 \%$ dos entrevistados atestaram utilizar o SUS somente para receber a medicação em foco, ou seja, não utilizam os serviços médicos do sistema público. Em matéria de renda, o maior percentual, correspondendo a $38 \%$ dos beneficiados, recebe de 2 a 5 salários mínimos. Dos entrevistados, $58 \%$ possuem ensino médio, e 40\%, o ensino superior. Dos pacientes ouvidos, $96 \%$ possuem casa própria quitada, enquanto $18 \%$ encontram-se pagando as prestações da casa própria. (TERRAZAS, Fernanda Vargas. O Poder judiciário como voz institucional dos pobres. Disponível em: <http://bibliotecadigital.fgv.br/ojs/index.php/rda/article/viewFile/8047/6837>. Acesso em: 20 fev 2018.)
} 
perspectivas diferentes, o organicismo e o utilitarismo. Para o organicismo, o interesse público seria algo superior e diferente ao somatório dos interesses particulares dos membros de uma comunidade política. Uma das críticas ao organicismo é que nele a prioridade absoluta do coletivo sobre o individual acabaria asfixiando a individualidade, que passa a ser instrumentalizada em proveito de um suposto "organismo superior" (SARMENTO, 2012).

Sarmento (2012) vai tentar encontrar no utilitarismo um fundamento ético alternativo para a supremacia do interesse público. Tal perspectiva advoga a tese de que o melhor caminho a ser seguido em casa caso será aquele que promover, em maior escala, o bem-estar, o prazer, a felicidade ou as preferências racionais do maior número de pessoas, contudo, o autor considera que essa ética consequencialista não se aplicaria aos direitos fundamentais, que devem ser protegidos, mesmo quando contrariem os interesses da maioria dos membros da coletividade.

O autor também analisa o individualismo, que tende a afirmar a primazia dos interesses particulares de cada um sobre aqueles pertencentes a coletividade, filosofia subjacente ao Estado Liberal Burguês, que hoje serve ao pensamento neoliberal:

De uma forma caricatural, pode-se afirmar que, pela cosmovisão individualista, a sociedade é um lócus de competição, e não da cooperação, e é bom que assim o seja, pois a competição faz com que prosperem os mais aptos, de forma a aperfeiçoar a humanidade. Trata-se do darwinismo social em sua versão mais crua (SARMENTO, 2012, p.109).

Já os comunitaristas criticam essa visão, afirmando que ela negligenciaria a importância dos laços sociais para a construção da personalidade humana. A Constituição de 88 abre-se para valores comunitários, preocupando-se com a proteção e promoção da cultura nacional (art.215 e 216 da CF), consagra direitos transindividuais, e institui alguns limites para o exercício de direitos individuais, decorrentes não da tutela de outro direitos de terceiros, mas da proteção a interesses gerais da coletividade (SARMENTO, 2012).

Após essas considerações sugere-se uma teoria meio-termo entre o liberalismo e o comunitarismo, o que chama de personalismo:

O personalismo afirma a primazia da pessoa humana sobre o Estado e qualquer entidade intermediária, e reconhece no indivíduo a capacidade moral de escolher seus projetos e planos de vida. Mas não adota uma leitura abstrata e metafísica da pessoa, pressupondo, ao contrário, tanto a existência de carências humanas materiais - que devem ser superadas como o apoio estatal - como a importância dos vínculos sociais na constituição da própria personalidade. Para o personalismo, é absurdo falar em supremacia do interesse público sobre o particular, mas também não é correto atribuirse primazia incondicionada aos direitos individuais em detrimento dos interesses da coletividade (SARMENTO, 2012, p. 117). 
Diante de conflitos entre direitos fundamentais e interesses públicos de estatura constitucional, pode-se falar na linha de Alexy, numa precedência prima facie. Esta procedência implicaria na atribuição de um peso inicial superior a estes direitos no processo ponderativo, o que significaria reconhecer que há um ônus argumentativo maior para que interesses públicos possam eventualmente sobrepujá-los (SARMENTO, 2012). Alexy (1994, p.207), ao referir-se às colisões entre direitos individuais e direitos coletivos, se manifesta da seguinte forma:

Se sostendrá que una determinación substancial general de la relación entre derechos
individuales y bienes colectivos está impuesta por razones normativas em virtud de
una procedencia prima facie de los derechos individuales. El argumento principal
consiste en (...) la necessidad de um orden normativo de la vida social que tome el
individuo em serio. El concepto de tornar em serio no implica que las posiciones de
los indivíduos no puedan ser eliminadas o restringidas em aras de bienes colectivos
pero si que para ello tiene que ser possible una justificación suficiente. (...) Esta
precedencia prima facie se expressa em una carga de la argumentación en favor de los
derechos individuales y en contra de los bienes coletivos.

A tentativa de se reconhecer um radical subjetivo a todos os direitos fundamentais (inclusive os sociais) acabou por gerar um ativismo judicial desenfreado. É claro que não se pode negar a dimensão subjetiva dos direitos sociais. Contudo, a atitude de alguns juízes de admitir a concessão judicial individualizada de pretensões jurídicas cuja titularidade muitas vezes é transindividual (difusa ou coletiva), consiste em atribuir uma primazia incondicionada aos direitos individuais em detrimento dos interesses da coletividade, uma vez que existe uma política de saúde pública universalmente planejada em execução.

Para Hachem (2013), assimilou-se uma explicação acertada a respeito do caráter subjetivo dos direitos fundamentais, mas sem a incorporação concomitante do significado da feição objetiva de tais direitos:

E com isso, passou-se a admitir a subjetivação individual de pretensões jusfundamentais de natureza transindividual - as quais, embora produzam efeitos jurídicos relevantes, nem sempre autorizam a postulação fracionada da prestação estatal, por conta de seu caráter indivisível (HACHEM, 2013, p.631).

Se a lógica subjetivista se mostra insuficiente, seja pelas ofensas que causa ao princípio da igualdade, seja pelo caos que possa causar no sistema financeiro público, a direção a ser tomada deve ser explorar a dimensão objetiva do direito à saúde ${ }^{40}$.

\footnotetext{
${ }^{40}$ Sarlet aponta que no Brasil, ao contrário do que se passa na Espanha e Portugal, "a referida perspectiva objetiva dos direitos fundamentais ainda não foi objeto de estudo mais aprofundado e encontrando, por isso, tímida, mas crescente (em termos quantitativos e qualitativos) aplicação" (SARLET, Ingo Wolfgang. A eficácia dos direitos fundamentais. Uma teoria geral dos direitos fundamentais na perspectiva constitucional. 10 ed. rev. atual. e ampl. Porto Alegre: Livraria do Advogado Ed., 2009, p.141).
} 
Como um dos desdobramentos dessa perspectiva objetiva dos direitos fundamentais, que será bastante útil para garantir a prevalência e aprimoramento das prestações de caráter transindividual, Sarlet (2009) menciona a função outorgada aos direitos fundamentais sob o aspecto de parâmetros para a criação e constituição de organizações (ou instituições) estatais e para o procedimento:

\footnotetext{
Nesse sentido, sustenta-se que, com base no conteúdo das normas de direitos fundamentais é possível se extrair consequências para a aplicação e interpretação das normas procedimentais, mas também para uma formatação de direito organizacional e procedimental que auxilie na efetivação da proteção aos direitos fundamentais, de modo a se evitarem os riscos de uma redução do significado do conteúdo material deles. Neste contexto, há que considerar a íntima vinculação entre direitos fundamentais, organização e procedimento, no sentido de que os direitos fundamentais são, ao mesmo tempo e de certa forma, dependentes da organização e do procedimento (no mínimo, sofrem uma influência da parte destes), mas simultaneamente também atuam sobre o direito procedimental e as estruturas organizacionais (SARLET, 2009, p. 150).
}

Portanto, a prestação dos serviços públicos que asseguram os direitos fundamentais, dentre eles o da saúde, deve tanto garantir esse direito por meio de procedimentos, como também sofre influência dos direitos fundamentais sobre seu procedimento e estruturas organizacionais.

Tratando do papel da Administração pública no cenário das distorções causadas pelo excesso de judicialização, Sarlet (2013) sugere que o aperfeiçoamento da via administrativa (clareza, simplicidade e acesso às informações, à desburocratização, à tempestividade, entre outros aspectos) constitui um ajuste necessário e possível, e se insere, num plano mais amplo, na noção de boa governança que também e acima de tudo deve serviços públicos essenciais à garantia de uma vida digna, o que, por sua vez, implica ampliação e aperfeiçoamento dos mecanismos social.

Sabe-se que quanto mais efetivo for o acesso pela via administrativa, menos trilhado será o caminho jurisdicional e ambas as atividades devem ser constantemente aprimoradas a fim de que sua ineficiência não se torne um obstáculo para a eficácia e efetividade do direito fundamental saúde.

Conclui-se que o direito fundamental à saúde apresenta multifuncionalidade e, dependendo da pretensão jurídica que se queira obter judicialmente, ela pode relacionar-se ao indivíduo, à coletividade ou de caráter difuso, portanto não se pode enquadrá-lo como direito individual ou só coletivo. O importante é que, no momento do ingresso da ação, delimite-se bem qual prestação jurídica se está querendo, sob pena de ser indeferido sob a alegativa de que é um bem individual ou de que é um bem que só possa ser buscado na via coletiva. 
Uma das propostas de evitar o ativismo exagerado referente às pretensões individuais teria como parâmetro uma limitação de ações com base na capacidade econômica do cidadão, sob pena de deferir toda e qualquer prestação em direito à saúde, a toda e qualquer pessoa. Contudo, essa alternativa é extremamente difícil de operacionalizar sem se incidir numa provável violação ao princípio da isonomia.

Diante do contexto de judicialização excessiva na área da saúde, a consideração da multifuncionalidade desse direito é de suma importância para o entendimento de que determinadas prestações têm caráter transindividual, devendo ser evitada sua subjetivação individual na via judicial.

Pretensões dessa natureza deverão realizar-se prioritariamente através do acesso ao serviço público de saúde adequado, pois é, em via de regra, por meio dele que o Poder Público logrará proporcionar aos cidadãos uma tutela efetiva do direito à saúde constitucionalmente consagrado.

Portanto, no combate à judicialização, é urgente que sejam concentrados esforços principalmente no aprimoramento do serviço. No próximo tópico, busca-se demonstrar quais os entraves para a prestação de um serviço público de saúde de qualidade, bem como alternativas que estão sendo adotadas pela Administração Pública para melhora na sua prestação.

\subsection{Os óbices e os avanços na prestação de um serviço de saúde adequado}

Brito (2017) destaca que, na área da saúde, uma das primeiras dificuldades que se apresentam para a construção de um sistema universal diz respeito ao financiamento. Apesar de um relativo aumento nos gastos com saúde nos últimos dez anos, comparativamente aos demais países do mundo, esse gasto se encontra abaixo da média mundial.

Durante a Audiência Pública $\mathrm{n}^{\circ}$ 4, realizada o Supremo Tribunal Federal, que teve por objeto analisar, entre outras questões, as consequências da atuação do Poder Judiciário para a ordem, a saúde e a economia pública, Antônio Carlos Fiqueiredo Nardi, então presidente do Conselho de Secretários Municipais de Saúde, pontuou que:

[...] um dos grandes problemas da garantia do direito à saúde no Brasil é o subfinanciamento da saúde pública. Em 2009, os recursos gastos na saúde pública e privada não chegavam à $8 \%$ do $\mathrm{PIB}$, comparativamente pouco em relação aos outros sistemas universais de saúde, cuja média mundial era de $10 \%$ do PIB. Os gastos per capita (público e privado) no Brasil em 2009 eram em torno de US\$700, enquanto em outros países variavam entre US\$3.000 e US\$7.500 per capita (BRITO, 2017, p.222). 
Embora mais recentemente o gasto público com a saúde tenha sido ampliado, ele não parece traduzir-se em melhora na qualidade dos serviços prestados pelo Estado brasileiro. Para Brito (2017, p.223), algumas hipóteses podem ser consideradas:

a) recursos desperdiçados. Esse fato converge com o Relatório Mundial da Saúde ${ }^{41}$, que evidencia um desperdício de recurso por ineficiência da ordem de 20-40\%, nas estimativas mais conservadoras;

b) a ineficiência administrativa e o desperdício de recursos contribuem para o subfinanciamento dos prestadores de serviço na área da saúde. Como evidenciou Adib Domingos Janete, na AP. N.4, "a remuneração pelos serviços prestados não chega, muitas vezes, sequer a cobrir os $\operatorname{custos}^{42}$ (BRITO, 2017, p. 223).

Some-se a esta problemática o número ascendente de dependentes do Sistema Único de Saúde. Segundo dados da Agência Nacional de Saúde Suplementar (ANS), em março de 2017, havia um total de 47.606.341 milhões de brasileiros usuários de planos privados de saúde, revelando que apenas aproximadamente $23 \%$ da população brasileira possui plano privado: ou seja, cerca de $77 \%$ da população depende exclusivamente do SUS ${ }^{43}$. Na Tabela 1 é possível identificar a evolução dos números ano a ano, entre 2007 e 2017.

Tabela 1 - Beneficiários de planos privados de saúde por cobertura assistencial (Brasil - 20072017).

\begin{tabular}{lcc}
\hline Ano & $\begin{array}{c}\text { Beneficiários em planos privados de assistência } \\
\text { médica com ou sem odontologia }\end{array}$ & $\begin{array}{c}\text { Beneficiários em planos privados } \\
\text { exclusivamente odontológicos }\end{array}$ \\
\hline Dez /2007 & 39.316 .313 & 9.164 .386 \\
Dez /2008 & 41.468 .019 & 11.061 .362 \\
Dez /2009 & 42.561 .398 & 13.253 .744 \\
Dez /2010 & 44.937 .350 & 14.514 .074 \\
Dez /2011 & 46.025 .814 & 16.669 .935 \\
Dez /2012 & 47.814 .411 & 18.525 .537 \\
Dez /2013 & 49.435 .589 & 19.569 .252 \\
Dez /2014 & 50.409 .378 & 20.325 .917 \\
Dez /2015 & 49.259 .250 & 21.162 .599 \\
Dez /2016 & 47.740 .783 & 21.970 .649 \\
\hline Dez/2017 & 47.606 .341 & 22.468 .131 \\
\hline
\end{tabular}

Fonte: Sistema de Informações de Beneficiários/ANS/MS - 03/2017.

\footnotetext{
${ }^{41}$ Organização Mundial de Saúde (OMS). Relatório Mundial da Saúde: Financiamento dos Sistemas de Saúde. Genebra: Who, 2010.143p. Disponível em: <http://www.who.int/whr/2010/whr10_pt.pdf>. Acesso em 26 maio 2014.

${ }^{42}$ Adib Domingos Janete.Audiência Pública da Saúde no Supremo Tribunal Federal: gestão do SUS e universalidade do sistema. 2009. 29 de abril de 2009. Disponível em: $<$ http://www.stf.jus.br/arquivo/cms/processoAudienciaPublicaSaude/anexo/Sr._Adib_Janete.pdf>. Acesso em 23 de nov. de 2013.

${ }^{43} \mathrm{O}$ Brasil tinha uma população de 207.660.929 de habitantes em $1^{\circ}$ de julho de 2017 , de acordo com estimativa do Instituto Brasileiro de Geografia e Estatística (IBGE) publicada em 30 de agosto de 2017, no Diário Oficial da União. Fonte: IBGE, Diretoria de Pesquisas - DPE, Coordenação de População e Indicadores Sociais - COPIS.
} 
Verifica-se que, entre 2007 e 2014, o número de usuários de planos privados de saúde foi crescente, com aumento médio na casa de $3 \%$ ao ano. Todavia, a partir de 2014, verifica-se um recolhimento no setor em proporção ainda maior entre os anos de 2015 e 2016, no qual se calcula que no período de um ano, aproximadamente 1,5 milhões de brasileiros deixaram de ter plano de saúde.

Na contramão desses fatos, a Emenda Constitucional $n^{\circ}$ 95, de 15.12.16, altera o texto constitucional para instituir o Novo Regime Fiscal, limitando o crescimento das despesas do governo brasileiro também com a saúde durante o período de vinte anos.

Mariano (2017) ressalta que as regras desse novo regime não permitem o crescimento das despesas totais e reais do governo acima da inflação, nem mesmo se a economia estiver bem, o que diferencia o caso brasileiro de outras experiências estrangeiras que adotaram o teto de gastos públicos. $\mathrm{O}$ aumento dos investimentos em uma área dependerá do corte em outras. As novas regras desconsiderariam as taxas de crescimento econômico, como também as demográficas pelos próximos vinte anos, o que poderá acarretar o sucateamento das políticas sociais, especialmente nas áreas de saúde e educação, uma vez que não foram excluídos do teto, os percentuais obrigatórios de gastos nestas áreas ${ }^{44}$. No tocante, especificamente à área da saúde:

Sem essa exclusão do teto, o financiamento do Sistema Único de Saúde (SUS) nos Estados e Municípios será fortemente atingido, pois cerca de $2 / 3$ das despesas do Ministério da Saúde são transferidas fundo a fundo para ações de atenção básica, média e alta complexidade, assistência farmacêutica, vigilância epidemiológica e sanitária, entre outras, a cargo dos entes federados (MARIANO, 2017, p. 262).

Por outro lado, Brito (2017) ao analisar o Relatório Sistêmico de Fiscalização da Saúde, publicado pelo TCU em 2014 e o Relatório Mundial de Saúde, publicado pela Organização Mundial de Saúde (OMS) em 2010, chegou à conclusão de que nem mesmo o aumento do financiamento resolverá os problemas e os dilemas dos sistemas de saúde, especialmente do SUS, se não for seguido de eficiência na gestão.

O Relatório Sistêmico de Fiscalização da Saúde, produzido pelo Tribunal de Contas da União (TCU), em 2013, e publicado em março de 2014, foi dirigido fundamentalmente ao

\footnotetext{
${ }^{44}$ Para a autora, a desvinculação das despesas obrigatórias com saúde e educação é inconstitucional, "pois atenta contra o princípio lógico da vedação ao retrocesso social, consubstanciada no plano do direito positivo, no rol das cláusulas pétreas constitucionais do $\$ 4^{\circ}$ do art.60" (MARIANO, Cynara Monteiro. Emenda Constitucional 95/2016 e o teto dos gastos públicos: o Brasil de volta ao estado de exceção econômico e ao capitalismo do desastre. Revista de Investigações Constitucionais. Curitiba, vol.4, n.1, p.259-281, jan./abril.2017, p.263).
} 
Congresso Nacional e aos gestores públicos. Para coleta de dados, foram visitados 114 hospitais federais, estaduais e municipais e dois hospitais classificados como entidades sem fins lucrativos em todo o Brasil. Realizou-se análise documental e entrevistas com gestores das unidades visitadas e das Secretarias Municipais e Estaduais de Saúde, com representantes do Ministério Público Federal, do Ministério Público Estadual, das Defensorias Públicas, de conselhos profissionais, entre outros. Alguns dos problemas levantados referiram-se às áreas de emergência e internação; recursos humanos; medicamentos e insumos; equipamentos, estrutura física e apoio; comissão de controle de infecção hospitalar; sistemas informatizados (BRITO, 2017).

Brito (2017, p.228) destaca algumas das conclusões do relatório:

1) Em relação à quantidade de leitos por habitante, vários Estados não possuíam a quantidade de leitos adequada e a oferta de leitos vem sendo reduzida nos últimos anos.

2) Há superlotação das principais emergências hospitalares, com pacientes sendo atendidos e internados nos corredores das unidades em macas, cadeiras ou bancos. Nos hospitais que possuíam emergência, 64\% deles apresentavam taxa de ocupação acima de $100 \%$. Além disso, existe uma longa espera de consultas, realização de exames ou procedimentos cirúrgicos.

3) Há um número insuficiente de equipamentos médicos que possam garantir quantidade, qualidade e tempestividade dos procedimentos realizados no âmbito das unidades hospitalares. Além do déficit de profissionais capacitados para operar os equipamentos, a inadequação da estrutura física para instalação e utilização deles e o alto custo de aquisição e manutenção de muitos equipamentos são agravantes a considerar.

4) Há deficiência de profissionais para atuar na saúde. Essa insuficiência é maior para 'outros profissionais' (não médicos, não enfermeiros, 18\%) do que para enfermeiros (16\%) e médicos (12\%) quando associado à existência de leitos bloqueados. [...]

7) Há insuficiência de medicamentos e insumos na maioria dos hospitais visitados, muitas vezes devido à falhas no processo licitatório (incluindo dispensa de licitação por motivo emergencial, como uma prática 'cotidiana e institucionalizada') e carência de instrumentos de gestão, o que tem contribuído para a restrição na realização de procedimentos médicos.

8) Pelo menos 53\% das unidades hospitalares e os estoques centrais nas Secretarias de Saúde não possuíam sistemas e procedimentos adequados para a logística de entrada e saída de medicamentos. A maioria das unidades hospitalares adota o sistema de distribuição coletivo para a distribuição dos medicamentos aos pacientes internados, que é o mais primitivo e menos econômico de todos (BRITO, 2017, p. 228).

Apesar dos problemas relatados na conclusão do Relatório, o Tribunal de Contas da União considera que o sistema de saúde brasileiro tem melhorado em vários aspectos nos últimos anos, como por exemplo, no aumento da expectativa de vida, na redução de indicadores de mortalidade, no maior acesso às ações e aos serviços de saúde e no crescimento do gasto público na área social. Todavia, os resultados apresentados demonstraram que apesar de alguns avanços, a falta de articulação do Ministério da Saúde e dos demais setores da Administração 
Pública dos três entes federativos constitui um obstáculo à institucionalização do planejamento em saúde, componente fundamental de qualquer gestão eficiente (BRITO, 2017).

Para a autora a judicialização, em parte, é consequência da precária elaboração e implementação das políticas públicas, bem como da desorganização administrativa na prestação de serviços públicos de saúde (BRITO, 2017).

Ao tratar do tema da judicialização da saúde, Bucci (2017, p. 35) ressalta a importância de algumas experiências bem-sucedidas de redução qualificada da judicialização da saúde, iniciativas locais, envolvendo Secretarias de Saúde, em conjunto com outros atores jurídicos fundamentais, como as Procuradorias dos Estados e Municípios e as Defensorias Públicas:

É o que exemplifica a experiência do Paraná, que informa a organização da Secretaria
de Saúde para a melhoria das condições para a produção da resposta no processo
judicial. Medidas básicas de organização passaram a ser adotadas, tais como a criação
de uma 'porta de entrada' para o recebimento das ordens judiciais, implantação de um
sistema de informação gerencial com dados sobre os pacientes e a comunicação mais
constante entre a Procuradoria Geral do Estado (PGE). Os pedidos passaram a ser
coordenados com a programação de compras realizadas por uma central de
medicamentos, adotando-se a rotina de informar a retirada do produto pelo paciente.
Passaram, também, a ocorrer encontros e seminários visando compartilhar
informações e orientações sobre as ações judiciais, envolvendo os vários atores
institucionais participantes (BUCCI, 2017, p. 78).

Essa coordenação entre as esferas da saúde e do direito: da Advocacia Pública e Secretarias de Saúde trabalhando juntas, em continuidade, criando condições para que os procedimentos de solução se estabeleçam de maneira suficientemente institucionalizada, poderia reduzir, muito provavelmente, a procura pela via judicial, muito mais trabalhosa, morosa e cara (BUCCI, 2017).

Novos modelos de interação institucional serão melhor discutidos ao longo do quarto capítulo do presente estudo, cumpre neste momento, contudo, ressaltar outras estratégias propostas por referida autora para a redução da judicialização da saúde, que envolveriam uma mudança na regulamentação:

No âmbito do Poder Executivo caberia uma revisão de documentos oficiais de três políticas, de modo a permitir uma compreensão mais imediata de como atuam a Política Nacional de Medicamentos, a Política Nacional de Assistência Farmacêutica e a Assistência Terapêutica, a fim de que a complexidade da matéria não sirva de escusa para impedir que se dê a leigos, em particular juízes e juízas, membros do Ministério Público, Defensorias e Advocacia Pública, condição de fazer a aplicação mais adequada das normas que regem essa política (BUCCI, 2017).

No âmbito do conjunto dos Poderes Executivo e Legislativo, seria necessário não apenas elaborar um texto normativo consolidado, integrando as várias portarias e resoluções que hoje 
tratam de maneira fragmentada da política, mas de complementá-lo com a descrição de responsabilização dos vários agentes, tendo em mente a perspectiva do usuário final (BUCCI, 2017).

No âmbito conjunto dos poderes Executivo e Legislativo, entende-se que o saneamento de eventuais deficiências da política de assistência farmacêutica passaria, necessariamente, pela consolidação das listas, mas nas normas haveria pouca referência ao atendimento aos usuários:

\begin{abstract}
A preocupação do Poder Público em disciplinar de forma mais estrita o conceito de integralidade, para limitar o que pode ser esperado do sistema de saúde, não foi acompanhada de iniciativa correspondente tratando do outro lado da moeda, isto é, o que deve ser exigido do sistema, com base no direito dos usuários. Interessante notar nesse ponto, o laconismo do texto da Lei n.8.080, de 1990, que utiliza o termo 'usuário' uma única vez, no art. $7^{\circ}$, VI, entre os princípios e diretrizes do SUS: VIdivulgação de informações quanto ao potencial dos serviços de saúde e a sua utilização pelo usuário; A regulamentação desse aspecto não deve ser uma norma retórica e enunciar uma lista ampla e vaga de direitos dos usuários. Ao contrário, seu caráter deve ser oposto, norma de caráter abrangente, que discipline os procedimentos em que se desdobram as ações de saúde, etapa a etapa, combinados com mecanismos cogentes, que, atribuindo consequências ao descumprimento torne obrigatória a observância desses 'protocolos de atendimento'. Dessa maneira poderá ficar mais claramente caracterizada eventual omissão do Poder Público, seja quanto à prestação, em si, seja quanto à justificativa da negativa do atendimento no caso concreto (BUCCI, 2017, p. 83) grifos do original.
\end{abstract}

A Portaria $\mathrm{n}^{\mathrm{o}} 1.820$, de 13 de agosto de 2009, publicada no Diário Oficial da União $\mathrm{n}^{\circ}$ 155, de 14 de agosto de 2009, que dispõe sobre os direitos e deveres dos usuários da saúde revogou a Portaria $n^{\circ}$ 675, de 30 de março de 2006, publicada no Diário Oficial da União $\mathrm{n}^{\circ} 63$, de 31 de março de 2006. A Carta dos Direitos dos Usuários da Saúde foi aprovada pelo Conselho Nacional de Saúde (CNS) em sua 198 Reunião Ordinária, realizada no dia 17 de junho de 2009. Com o objetivo de garantir o acesso universal e igualitário às ações e serviços para promoção, proteção e recuperação da saúde, o documento tem como base seis princípios básicos de cidadania, caracterizando-se como uma importante ferramenta para que o cidadão conheça seus direitos e deveres no momento de procurar atendimento de saúde, tanto público como privado. São eles:

1. Todo cidadão tem direito ao acesso ordenado e organizado aos sistemas de saúde.

2. Todo cidadão tem direito a tratamento adequado e efetivo para seu problema.

3. Todo cidadão tem direito ao atendimento humanizado, acolhedor e livre de qualquer discriminação.

4. Todo cidadão tem direito a atendimento que respeite a sua pessoa, seus valores e seus direitos.

5. Todo cidadão também tem responsabilidades para que seu tratamento aconteça da forma adequada.

6. Todo cidadão tem direito ao comprometimento dos gestores da saúde para que os princípios anteriores sejam cumpridos (MINISTÉRIO DA SAÚDE, 2009). 
Não é preciso esforço para perceber que há grande distância na efetivação prática das premissas da Carta de Direito dos Usuários do SUS, um grande problema é saber quem faz a sua fiscalização.

A partir da edição da Lei n ${ }^{\circ}$ 13.460/2017, que regulamenta o mandamento constitucional contido no art. 37, $\S 3^{\circ}$, I, os usuários dos serviços públicos da União, Estados e Municípios passaram a contar com um código de proteção e defesa do usuário do serviço público. Referida lei, que se aplica tanto à Administração Pública Direta, quanto à Indireta, trouxe alguns conceitos como o de usuário, no art. $2^{\circ}$ inciso I, “a pessoa física ou jurídica que se beneficia ou utiliza, efetiva ou potencialmente, de serviço público ${ }^{45}$ ", e de serviço público, no art. $2^{\circ}$ inciso II, como "atividade administrativa ou de prestação direta ou indireta de bens ou serviços à população, exercida por órgão ou entidade da administração pública ${ }^{46 "}$ "

No $\operatorname{art} .5^{\circ}$ foi previsto, novamente, como direito básico do usuário a adequada prestação dos serviços públicos, inclusive com a previsão de diretrizes que caracterizam o que seja essa prestação adequada:

I - urbanidade, respeito, acessibilidade e cortesia no atendimento aos usuários;

II - presunção de boa-fé do usuário;

III - atendimento por ordem de chegada, ressalvados casos de urgência e aqueles em que houver possibilidade de agendamento, asseguradas as prioridades legais às pessoas com deficiência, aos idosos, às gestantes, às lactantes e às pessoas acompanhadas por crianças de colo;

IV - adequação entre meios e fins, vedada a imposição de exigências, obrigações, restrições e sanções não previstas na legislação;

$\mathrm{V}$ - igualdade no tratamento aos usuários, vedado qualquer tipo de discriminação;

VI - cumprimento de prazos e normas procedimentais;

VII - definição, publicidade e observância de horários e normas compatíveis com o bom atendimento ao usuário;

VIII - adoção de medidas visando a proteção à saúde e a segurança dos usuários;

IX - autenticação de documentos pelo próprio agente público, à vista dos originais apresentados pelo usuário, vedada a exigência de reconhecimento de firma, salvo em caso de dúvida de autenticidade;

$\mathrm{X}$ - manutenção de instalações salubres, seguras, sinalizadas, acessíveis e adequadas ao serviço e ao atendimento;

XI - eliminação de formalidades e de exigências cujo custo econômico ou social seja superior ao risco envolvido;

XII - observância dos códigos de ética ou de conduta aplicáveis às várias categorias de agentes públicos;

\footnotetext{
${ }^{45}$ Diferente do que ocorre no CDC, a mera utilização potencial do serviço gera a caracterização de usuário.

${ }^{46}$ Emerson Gabardo anota que: "Infelizmente a lei utiliza uma expressão equivocada ao definir os sujeitos prestadores, dizendo que será serviço público a atividade "exercida" por órgão ou entidade da Administração. Isso não é verdade, pois o artigo $1^{\circ}$ é claro ao asseverar que a incidência se dá para serviços públicos prestados "direta ou indiretamente". A interpretação sistemática confirma este efeito, razão pela qual seria mais prudente este inciso utilizar a expressão "titularizada" ao invés de exercida. Disponível em: <"http://www.direitodoestado.com.br/colunistas/emerson-gabardo/o-novo-codigo-de-defesa-do-usuario-doservico-publico-lei-13-460-17> Acesso em: Acesso em: 10 de nov 2017.
} 
XIII - aplicação de soluções tecnológicas que visem a simplificar processos e procedimentos de atendimento ao usuário e a propiciar melhores condições para o compartilhamento das informações;

XIV - utilização de linguagem simples e compreensível, evitando o uso de siglas, jargões e estrangeirismos; $\mathrm{e}$

XV - vedação da exigência de nova prova sobre fato já comprovado em documentação válida apresentada (BRASIL, 2017).

Foi previsto no $\operatorname{art} .7^{\circ}$, que os órgãos e entidades abrangidos pela lei divulgarão a Carta de Serviços ao Usuário ${ }^{47}$, com o objetivo de informá-los sobre os serviços prestados, as formas de acesso a esses serviços e seus compromissos e padrões de qualidade de atendimento ao público. A Carta de Serviços ao Usuário conterá informações claras e precisas em relação a cada um dos serviços prestados, apresentando, no mínimo, informações relacionadas aos: a) serviços oferecidos; b) requisitos, documentos, formas e informações necessárias para acessar o serviço; c) principais etapas para processamento do serviço; d) previsão do prazo máximo para a prestação do serviço; e) forma de prestação do serviço; e f) locais e formas para o usuário apresentar eventual manifestação sobre a prestação do serviço.

Além das informações acima descritas, a Carta de Serviços ao Usuário deverá detalhar os compromissos e padrões de qualidade do atendimento relativos, no mínimo, aos seguintes aspectos:

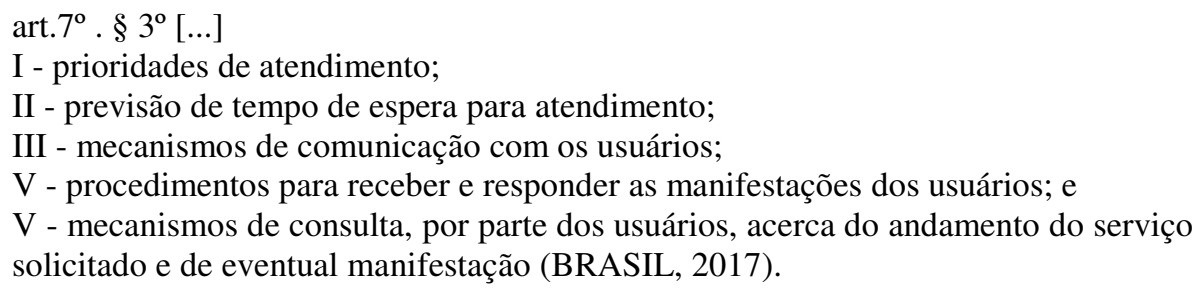

No art. $9^{\circ}$ está previsto que para garantir seus direitos, o usuário poderá apresentar manifestações perante a administração pública acerca da prestação de serviços públicos (que pode ser feita por meio eletrônico, correspondência convencional ou verbalmente, reduzindose a termo) que será dirigida à ouvidoria do órgão ou entidade responsável, e nos locais onde não haja ouvidoria, diretamente ao órgão ou entidade responsável pela execução do serviço e ao órgão ou entidade a que se subordinem ou se vinculem.

Outra novidade da lei é a previsão, no art.18, de conselhos de usuários, responsáveis por acompanhar a prestação dos serviços; avaliá-los; propor melhorias; contribuir na definição de diretrizes para o adequado atendimento ao usuário; e acompanhar e avaliar a atuação do ouvidor.

\footnotetext{
${ }^{47} \mathrm{O}$ artigo $7^{\circ}$ estabelece para toda a administração algo que o "Decreto Cidadão" (Decreto no 6932/09) já previra, que é a existência de Cartas de Serviços ao Usuário.
} 
Outra inovação é a avaliação continuada dos serviços, disposta no art.23, nos seguintes aspectos: a) satisfação do usuário com o serviço prestado; b) qualidade do atendimento prestado ao usuário; c) cumprimento dos compromissos e prazos definidos para a prestação dos serviços; d) quantidade de manifestações de usuários; e) medidas adotadas pela administração pública para melhoria e aperfeiçoamento da prestação do serviço.

A avaliação será realizada por pesquisa de satisfação feita, no mínimo, a cada um ano, ou por qualquer outro meio que garanta significância estatística aos resultados. O resultado da avaliação deverá ser integralmente publicado no sítio do órgão ou entidade, incluindo o ranking das entidades com maior incidência de reclamação dos usuários e servirá de subsídio para reorientar e ajustar os serviços prestados, em especial quanto ao cumprimento dos compromissos e dos padrões de qualidade de atendimento divulgados na Carta de Serviços ao Usuário.

Constituindo-se num importante canal de diálogo entre os órgãos públicos e a sociedade, essas medidas têm como foco ampliar a participação do usuário na gestão do serviço, aumentando o controle social sobre eles.

Contudo, perdeu-se a oportunidade nos termos do que propôs Bucci, de um documento que efetivamente pudesse servir de base para uma normatização mais efetiva para evitar a judicialização, sendo necessário o aspecto normativo, pelo meio do qual se definisse o encadeamento de ações e seus efeitos, resguardando-se dentre outros direitos: a) o de ser informado; b) o de obter uma resposta do sistema de saúde, em prazo certo; c) o de ter caracterizada a negativa como pressuposto hábil à atuação do direito subjetivo. Espera-se que a Carta do Usuário, seja renovada, suprindo-se essa lacuna (DALLARI, 2017).

Outra iniciativa relevante no tocante a prestação do serviço público de saúde, é a chamada Plataforma de Cidadania Digital, com base no Decreto Federal n ${ }^{\circ}$ 8.936/2016, que visa aprimorar a oferta de serviços. Consistente num canal online único e integrado onde o cidadão, através de um cadastro, poderá solicitar serviços públicos (como emissão de passaportes, agendamento de consultas etc.) acompanhar o andamento da sua demanda e avaliar o serviço que foi prestado. Esses serviços digitais, têm como proposta a redução de custos para o governo e a facilitação do atendimento aos cidadãos, que atualmente esperam em longas filas presenciais.

O caminho parece correto, pois se a intenção é barrar a judicialização, deve se observar a qualidade na prestação do serviço de saúde pública, focando nas soluções de efetividade. Os problemas da saúde só serão solucionados através de uma prestação célere e de qualidade. Delegar somente aos órgãos privados essa responsabilidade ou repassá-la para o Judiciário, 
causa o efeito da fragmentação de um direito que é transindividual, enfraquecendo a luta pelo aperfeiçoamento dos serviços, uma vez que os cidadãos passam a se comportar como meros consumidores de serviços precarizados ao invés de se enxergarem como cidadãos capazes de exigir um serviço universal de melhor qualidade como um direito subjetivo.

Tem-se que ter a consciência de que todos os cidadãos são igualmente responsáveis pela defesa do SUS, afinal constitui uma das diretrizes constitucionais de organização das ações e dos serviços de saúde, prevista no art. 198, inciso III, a participação da comunidade, que hoje é exercida através da participação comunitária em Conferências de Saúde e Conselhos de Saúde (Lei no $8.142 / 90)$.

É interessante notar que a Lei Orgânica de Saúde (Lei nº.080/90) ressalta que o dever do Estado não exclui o das pessoas, da família, das empresas e da sociedade.

\footnotetext{
Art. $2^{\circ}$ A saúde é um direito fundamental do ser humano, devendo o Estado prover as condições indispensáveis ao seu pleno exercício.

$\S 1^{\circ} \mathrm{O}$ dever do Estado de garantir a saúde consiste na formulação e execução de políticas econômicas e sociais que visem à redução de riscos de doenças e de outros agravos e no estabelecimento de condições que assegurem acesso universal e igualitário às ações e aos serviços para a sua promoção, proteção e recuperação.

$\S 2^{\circ} \mathrm{O}$ dever do Estado não exclui o das pessoas, da família, das empresas e da sociedade (BRASIL, 1990).
}

Espera-se que mudanças legislativas venham a aprimorar o serviço, na medida em que abrem espaço para um feedback da sociedade usuária, todavia impende que essas iniciativas não constituam mera legislação simbólica e passem por uma efetiva fiscalização, gerando uma consequente diminuição do número de demandas judiciais.

Para a garantia desse serviço público de saúde adequado, a legislação é importante, mas não é suficiente se os direitos dos usuários não se efetivarem na prática e isso demanda um esforço conjunto de toda a sociedade. Deve-se abandonar a mentalidade individualista, estimulada, por exemplo, pela criação de planos populares, o que tende a dificultar a reivindicação coletiva pela eficácia da política pública de saúde universalmente planejada e gera mais judicialização. Deve ser realizada uma fiscalização efetiva desse serviço, através inclusive dos novos mecanismos que estão à disposição do usuário.

Como foi visto, a qualidade do serviço público adequado para superar suas conhecidas deficiências não depende só dos recursos orçamentários previstos para a sua prestação, mas de um melhor aproveitamento dos recursos e maior eficiência administrativa.

O combate à judicialização excessiva da saúde pública não pode deixar de lado a ideia de proteção da coletividade em relação às ações e omissões do Poder Público, ou daqueles entes que façam as suas vezes, buscando-se alternativas que tenham como o foco a saúde como direito 
objetivo e que primem pela eficiência na prestação do serviço. Os estudos na área jurídica devem ser voltados para identificar arranjos institucionais e formas de facilitar a interação entre as partes envolvidas na prestação das políticas de saúde pública, a fim também de verificar sua efetividade, uma vez que se propõem a aprimorar o serviço prestado à coletividade.

Ao longo do terceiro capítulo, busca-se compreender em que hipótese estaria o Poder Judiciário autorizado a interferir nas Políticas Públicas de saúde, considerando sua capacidade institucional. Também cumpre analisar as políticas judiciárias que visam aperfeiçoar e reduzir a judicialização. 


\section{A JUDICIALIZAÇÃo DA SAÚDE PÚBLICA}

No Estado Democrático de Direito brasileiro, a experiência de um Estado eminentemente legalista criou um ambiente favorável a promessas irrealizáveis, normas abusivamente programáticas, conceitos vagos, sem força para atender à demanda por justiça social. Neste contexto, a construção de dogmática constitucional dedicada à força normativa do texto da constituição de 1988 tem sido uma das principais tarefas dos doutrinadores brasileiros no século XXI.

O Poder Judiciário, que num Estado realmente "Democrático de Direito" deveria servir como "instância final”, ou última alternativa viável, acabou se tornando um importante via de acesso a qual cidadãos têm se dirigido a fim de fazer valer direitos individuais, coletivos ou difusos previstos constitucionalmente, uma vez que nenhuma lesão ou ameaça a direito está excluída dessa apreciação, nos termos do artigo $5^{\circ}, \mathrm{XXXV}$, da Constituição Federal.

Com o cenário exposto, os membros do judiciário estão em busca de uma leitura capaz de "atualizar" as normas constitucionais, a fim de atender aos anseios sociais. Num esforço por uma verdadeira concretização dos direitos fundamentais, a hermenêutica jurídica atravessa um novo estágio, sobretudo na Suprema Corte brasileira, deixando de ser auto-restritiva, para se tornar construtivista ${ }^{48}$.

Nessas circunstâncias, diversas críticas são dirigidas ao amplo espaço liberado à moderna interpretação da Constituição, principalmente ao ativismo, dentre elas a que alega a ausência de legitimidade democrática, sustentando que a atuação do Poder Judiciário no controle de políticas públicas desrespeita o processo que elege os seus representantes para a formulação das atividades necessárias para a coletividade.

A discussão trazida a lume no presente capítulo insere-se no contexto de crescente crítica a "judicialização excessiva", sobretudo proveniente da magistratura ordinária nas demandas relacionadas à concretização de prestações específicas relacionadas à saúde pública.

Tal intervenção judicial, quando apartada de considerações técnicas e jurídicas, especialmente no que envolve o fornecimento de medicamentos e determinação de procedimentos cirúrgicos, internações e outros cuidados à saúde, tem potencial para alterar o planejamento e execução dos orçamentos e pode resultar num considerável dispêndio de

\footnotetext{
${ }^{48}$ De fato, a efetivação dos direitos fundamentais tem sido realizada pelo Poder Judiciário, numa atuação que se estende bem além do que simplesmente dizer o direito diante de um ou outro caso concreto. Passou-se a legitimar a Jurisprudência como fonte criadora do direito, exaltando a importância dos juízes como agentes fundamentais nesse processo voltado à realidade.
} 
recursos públicos para o cumprimento de decisões judiciais. Ressalte-se que, por apresentarem efeitos sistêmicos, tais decisões poderão resultar em prejuízos até mesmo para a própria política de saúde pública universal programada pelo Estado.

O ativismo judicial tem gerado repercussões nas relações sociais e, especificamente, quanto ao modo de se ver a função judicial dentro do ordenamento jurídico, esbarrando-se em dilemas existentes em relação à efetividade das políticas públicas e o limite de atuação do juiz frente a separação constitucional dos poderes e aos limites econômico-financeiros inerentes ao tema. Mas não só isso, o ativismo também pode comprometer o acesso universal e igualitário à saúde, resultando em preferências.

O controle judicial do orçamento, no tocante às demandas individuais, para averiguar, caso a caso, se há ou não o descumprimento da Constituição, pode levar o magistrado a descumpri-la, conforme muito bem destaca Barroso (2009, p.35), no que se refere à judicialização dos medicamentos:

No limite, o casuísmo da jurisprudência brasileira pode impedir que políticas coletivas, dirigidas à promoção da saúde pública, sejam devidamente implementadas. Trata-se de hipótese típica em que o excesso de judicialização das decisões políticas pode levar à não realização prática da Constituição Federal. Em muitos casos, o que se revela é a concessão de privilégios a alguns jurisdicionados em detrimento da generalidade da cidadania, que continua dependente das políticas universalistas implementadas pelo Poder Executivo.

[...] Mais recentemente, vem se tornando recorrente a objeção de que as decisões judiciais em matéria de medicamentos provocam a desorganização da Administração Pública. São comuns, por exemplo, programas de atendimentos integral, no âmbito dos quais, além de medicamentos, os pacientes recebem atendimento médico, social e psicológico. Quando há alguma decisão judicial determinando a entrega imediata de medicamentos, frequentemente o Governo retira o fármaco do programa, desatendendo a um paciente que o recebia regularmente, para entregá-lo ao litigante individual que obteve a decisão favorável. Tais decisões privariam a Administração da capacidade de se planejar, comprometendo a eficiência administrativa no atendimento ao cidadão. Cada uma das decisões pode atender às necessidades imediatas do jurisdicionado, mas, globalmente, impediria a otimização das possibilidades estatais no que toca à promoção da saúde pública (BARROSO, 2009, p. 35).

Constata-se que são sérias as distorções que decorrem da excessiva concretização judicial da assistência terapêutica. Espíndola e Weidlich (2015) destacam que pretensões judiciais são invariavelmente acolhidas, inclusive sem o deferimento e produção de provas, sob o argumento de que o médico que acompanha o paciente possui competência para determinar a urgência e especificar qual o tratamento correto e a forma de promovê-lo, situação que denomina 'solipcismo médico' 49 .

\footnotetext{
${ }^{49}$ Para exemplificar, os autores relatam o acolhimento por parte da Corte Gaúcha de pedidos de fornecimento do medicamento Lucetins, para o tratamento da degeneração macular, com fundamento na recomendação do médico assistente do paciente sem, ao menos, atentar para a possibilidade de substituição desse fármaco por um semelhante
} 
No Brasil, a $13^{a}$ edição do Relatório Justiça em Números, divulgado pelo Conselho Nacional de Justiça (CNJ, 2017), que considera os processos ajuizados até 31/12/2016, realiza um diagnóstico sobre a litigiosidade na área da saúde, analisando dados de 90 tribunais pátrios. Por meio do acesso a painéis eletrônicos ${ }^{50}$, esse relatório permite a realização de consulta detalhada por classes e assuntos de processos judiciais. Destarte, a judicialização da saúde, considerando-se os processos ajuizados de 2014 a 2016, registrou-se um total de 1.054.203 novas ações judiciais, sendo que em 2011 essas demandas somavam 240.980 processos judiciais (CNJ, 2011). Observado o novo quadro, percebe-se um significativo aumento do número de demandas na área da saúde.

É evidente que a judicialização da saúde se institucionalizou e constitui mais uma forma de acesso ao Sistema Único de Saúde (SUS). No Estado do Ceará, segundo informações disponíveis no sistema de acompanhamento de processo do Conselho Nacional de Saúde (CNJ), no ano de 2016 tramitaram 4.699 novos casos (CNJ, 2017), comparando-se aos anos anteriores os números também revelam significativo aumento de litigantes em busca da garantia do direito à saúde.

Diante do exposto, o presente capítulo pretende ampliar o debate sobre a judicialização da saúde, sobretudo no campo específico da saúde pública, entendendo que o direito à saúde já se sustenta em ampla gama normativa, muitas vezes desconsiderada, o que faz premente promover uma cultura de autocontenção judicial. Destacando o caráter eminentemente político das políticas públicas e os limites tradicionalmente sustentados à intervenção judicial, referido capítulo também traz à discussão o argumento das capacidades institucionais proposto por Cass Sunstein e Adrian Vermeule, bem como descreve estratégias desenvolvidas para o aprimoramento das decisões envolvendo saúde pública tanto em âmbito nacional, como local.

\footnotetext{
e sensivelmente mais barato, no caso o Avastin, mesmo após manifestação dos próprios peritos do Tribunal de Justiça do Rio Grande do Sul (TJRS), que apontaram a ausência de superioridade de um medicamento em relação ao outro. Indaga ainda, se no caso estão sendo concretizados os direitos do demandante ou se está contemplando o interesse econômico dos laboratórios fabricantes do medicamento: "A quem o ativismo judicial vem servindo?" (ESPÍNDOLA, Angela Araújo da Silveira; WEIDLICH, Amanda de Morais. Judicialização e ativismo: as distorções decorrentes da excessiva concretização judicial da assistência terapêutica.RevistaParadigma.Ribeirão Preto, SP, ano. XX, V.24, N.1, p.121-150. Jan./Jun.2015, p. 134-136).

${ }^{50}$ Os dados reunidos nesse Relatório estão disponíveis por meio do "Justiça em Números Digital", ferramenta interativa on-line que permite livre navegação pelas estatísticas oficiais. Para utilização da ferramenta, o usuário deve acessar os painéis em dashboard disponíveis no link paineis.cnj.jus.br.
} 


\subsection{Saúde como direito social prestacional, subjetivo e de aplicabilidade imediata}

Cabe ressaltar que os direitos fundamentais como um todo, em razão de sua multifuncionalidade, podem ser classificados em dois grupos, notadamente, os direitos de defesa (negativos) e os direitos a prestações(positivos) $)^{51}$. Os direitos fundamentais sociais, constituem não só o direito subjetivo do cidadão de não ser obstado pelo Estado no exercício e fruição das chamadas "liberdades sociais", mas o de exigir prestações positivas por parte desse mesmo Estado, que garantam o mínimo necessário a uma existência digna.

No que tange ao direito fundamental social à saúde, especificamente, considera-se como um típico direito prestacional, exigindo atuações positivas do Estado, tais como o fornecimento de medicamentos, de atendimento médico e hospitalar, a realização de exames da mais variada natureza; mas que também pode constituir direto de defesa, ao impedir ingerências indevidas por parte do Estado e de terceiros na saúde do titular (SARLET, 2007).

Foi consagrada no art. $5^{\circ}, \S 1^{\circ}$, da $\mathrm{CF} / 88$, a aplicação imediata das normas definidoras dos direitos e garantias fundamentais. Por força deste dispositivo os direitos sociais estão em condições de serem diretamente aplicáveis, contudo, costuma-se imprimi-los um caráter meramente programático, ao contrário do que ocorre com os direitos individuais. A discussão acerca da efetividade das normas programáticas encerra amplas controvérsias doutrinárias e jurisprudenciais. A doutrina pátria não é uniforme.

Para Malmeistein (2016) essa disposição legal, aponta a supremacia natural dos direitos fundamentais. $\mathrm{O}$ autor defende que não haveria sentido em condicionar a aplicação dos direitos fundamentais a uma futura e incerta regulamentação legislativa, razão pela qual considera que a norma constitucional se torna fonte direta de comando e obrigações aos órgãos públicos, com uma força normativa autônoma, independentemente de qualquer regulamentação.

Também adota posição otimista Eros Grau (2003) para quem todas as normas definidoras de direitos e garantias fundamentais são auto-executáveis, independentemente de qualquer ato legislativo ou administrativo, devendo o Estado prontamente aplicá-las, decidindo pela imposição de seu cumprimento.

\footnotetext{
${ }^{51} \mathrm{~A}$ classificação em dois grupos tem inspiração na teoria dos quatro status desenvolvida por Georg Jellinek, que destaca as relações jurídicas (status) existentes entre o indivíduo e o Estado. Essa classificação entre direitos positivos e negativos, tem sido bastante criticada, uma vez que os direitos individuais e os políticos, originalmente de caráter negativo, também necessitam de pretensões positivas, políticas públicas, que demandam custos por parte do Estado, e não apenas os direitos sociais demandariam recursos públicos. (MARMELSTEIN, George. Curso de Direitos Fundamentais. 6.ed.rev.,atual. e ampl. São Paulo: Atlas, 2016, p.300)
} 
Em sentido contrário, para José Afonso da Silva (1998) as normas programáticas possuem eficácia limitada, não sendo inteiramente operantes relativamente aos interesses que lhes constituem objeto específico, necessitando de normas integrativas para que possam produzir os seus efeitos jurídicos de maneira plena. Tal categoria de normas não produziria, com a simples entrada em vigor, todos os efeitos essenciais, uma vez que o legislador constituinte não estabeleceu, sobre a matéria, uma normatividade para isso bastante, deixando essa tarefa ao legislador ordinário ou a outro órgão do Estado.

Adota posição intermediária Sarlet (2009), partindo da premissa de que o dispositivo normativo em análise não se aplica a toda a constituição, sob pena de equiparar direitos fundamentais e demais normas constitucionais, o autor supõe que referida norma impõe ao Estado a maximização da eficácia dos direitos fundamentais. A aplicação direta do dispositivo implicaria a inobservância de limites importantes, como a reserva do possível, a da falta de legitimação dos tribunais para aplicação de medidas sócio-econômicas, e a colisão de direitos fundamentais.

Assim, faz distinção entre dois grupos de normas: as de insuficiente normatividade, que precisam de uma interpretação do legislador para gerar a plenitude de seus efeitos, e as de suficiente normatividade, que não reclamam atos de natureza concretizadora e podem ser imediatamente aplicadas aos casos concretos (SARLET, 2009).

Para Barros (2010) a posição intermediária adotada por Sarlet seria a mais adequada, pois sendo a norma um princípio constitucional, não pode ser tratada como uma regra, com base no tudo ou nada. A sua eficácia deve ser analisada à luz do caso concreto, de acordo com a função que os direitos fundamentais desempenham no ordenamento jurídico. Além disso, a proposta de Sarlet também estaria de acordo com a eficácia subjetiva dos direitos fundamentais, no sentido de que, de acordo com a presunção anunciada, em regra, o dispositivo assegura aos cidadãos direitos subjetivos. Somente nos casos em que, após análise da hipótese concreta e da estrutura normativa, esta presunção (relativa) seja quebrada é que, após a devida fundamentação, os indivíduos não poderão exigir os direitos previstos nas normas definidoras de direitos fundamentais (BARROS, 2010).

A dimensão subjetiva dos direitos fundamentais está relacionada à capacidade que estes possuem de gerar direitos subjetivos, podendo ser concretizados judicialmente diante do Estado ou de mesmo de particulares. A dimensão subjetiva possibilita que os direitos fundamentais sejam postulados pelo indivíduo na esfera judicial, e estão, por exemplo, caso o Estado se negue a realizar determinada prestação necessária à saúde (fornecimento de medicamentos, realização de cirurgia etc.), o indivíduo poderá entrar com ação judicial exigindo seu cumprimento). Já a 
dimensão objetiva, implica que os direitos fundamentais são um conjunto de valores objetivos, que fornecem diretrizes materiais, se expandindo para todo o ordenamento jurídico, funcionando como sustentáculo para toda a ordem constitucional (ROCHA, 2011).

O Supremo Tribunal Federal tem precedente de que o art.196 da Constituição Federal gera direitos subjetivos, especialmente para as pessoas carentes, que não podem custear por conta própria o tratamento, conforme trecho transcrito da ementa:

O direito público subjetivo à saúde representa prerrogativa jurídica indisponível assegurada à generalidade das pessoas pela própria Constituição da República (art. 196). [...] O direito à saúde - além de qualificar-se como direito fundamental que assiste a todas as pessoas - representa conseqüência constitucional indissociável do direito à vida. [...] O reconhecimento judicial da validade jurídica de programas de distribuição gratuita de medicamentos a pessoas carentes, inclusive àquelas portadoras do vírus HIV/AIDS, dá efetividade a preceitos fundamentais da Constituição da República (arts. $5^{\circ}$, caput, e 196) e representa, na concreção do seu alcance, um gesto reverente e solidário de apreço à vida e à saúde das pessoas, especialmente daquelas que nada têm e nada possuem, a não ser a consciência de sua própria humanidade e de sua essencial dignidade. Precedentes do STF. (RE 271286 AgR, Relator(a): Min. CELSO DE MELLO, Segunda Turma, julgado em 12/09/2000, ACÓRDÃO ELETRÔNICO DJ 24-11-2000 PP00101 EMENT VOL-02013-07 PP-01409)

Quanto à possibilidade do controle judicial de políticas públicas, decisão do Min. Celso de Mello, na Arguição a Descumprimento de Preceito Fundamental no 45, demonstra que o Tribunal se manifesta favorável, ressaltando que decorre da dimensão política de sua jurisdição.

Ementa: Arguição de descumprimento de preceito fundamental. A questão da legitimidade constitucional do controle e da intervenção do poder judiciário em tema de implementação de políticas públicas, quando configurada hipótese de abusividade governamental. Dimensão política da jurisdição constitucional atribuída ao Supremo Tribunal Federal. Inoponibilidade do arbítrio estatal à efetivação dos direitos sociais, econômicos e culturais. Caráter relativo da liberdade de conformação do legislador. Considerações em torno da cláusula da "reserva do possível". Necessidade de preservação, em favor dos indivíduos, da integridade e da intangibilidade da arguição de descumprimento no processo de concretização das liberdades positivas(direitos constitucionais de segunda geração) STF, ADPF 45/2004, rel. Min. Celso de Mello, j. 1/07/2004.

Conforme seus julgados o STF considera o direito a saúde como direito subjetivo e em matéria de políticas públicas admite a intervenção judicial, quando configurada a hipótese de abusividade governamental. Contudo, a fim de evitar a judicialização e que o judiciário se torne um balcão de demandas da população, cumpre melhor definir os contornos desta intervenção, sobretudo quanto as demandas individuais. 
Afinal, são recorrentes os casos em que o Estado, mais especificamente os Poderes Executivo e Legislativo dele partes integrantes, não cumpre seu papel como garante dos direitos assegurados na Constituição. As políticas públicas desenvolvidas pela instituição estatal ficam muitas vezes aquém do esperado, não sendo capazes de gerar bem-estar social.

No próximo tópico se discute o caráter político das políticas públicas e os limites da intervenção judicial com foco nas decisões de caráter individual, de efeitos sistêmicos, diante das questões da reserva orçamentária, da reserva do possível e da reserva de contingência.

\subsection{O caráter político das políticas públicas em saúde e os limites a intervenção judicial}

Para que os direitos fundamentais sociais sejam efetivados é necessária a adoção de medidas concretas, planejadas e bem definidas, que serão prestações positivas, denominadas Políticas Públicas. Segundo Bucci (2002, p.241) as políticas públicas são os "programas de ação governamental visando a coordenar os meios à disposição do Estado e as atividades privadas, para a realização de objetivos socialmente relevantes e politicamente determinados".

Sua definição demonstra que as políticas refletem a escolha de mecanismos para se atingir os objetivos do Estado e que referida escolha conta com a participação tanto de entes públicos como privados. Referidas políticas, especialmente quando voltadas a implementação de prestações materiais, tem no Poder Executivo a agência específica para sua concepção, mas podem ser desenvolvidas no âmbito dos demais poderes.

Bilhim (2004) destaca que as políticas públicas implicam a decisão enquanto escolha entre alternativas, por parte do governo, de fazer algo ou não, tendo em vista a produção de resultados e ressalta que não fazer é também uma escolha.

As políticas e programas que estruturam e conduzem a vida política e social atual são o resultado de interações de muito diferentes grupos e organizações, a mistura de muito diferentes opiniões e interesses. Nesta concepção pluralista do político não há propriamente uma sociedade, mas sociedades. Há sempre um mosaico ou um complexo de grupos, onde cada grupo se apresenta como uma massa de atividades, onde há flutuações de adesões individuais. Há uma pluralidade de centros de decisão, uma vasta constelação de pequenos poderes de contornos e articulações complexas (BILHIM, 2004).

Em muitas áreas não faz mais sentido pensar as políticas públicas como o resultado de um processo de decisão do governo. O governo não deixa de ser um ator e, em certos casos, um ator de muito peso; mas as políticas públicas que guiam a sociedade são o resultado de um conjunto de interações complexas envolvendo múltiplos grupos de interesses, acabando por se 
combinar de uma maneira normalmente muito imprevisível e não menos fascinante (BILHIM, 2004).

Trata-se de uma atividade bastante complexa, que envolve uma série de etapas; em regra costuma-se apontar como etapas de uma política pública: a formulação, a implementação e a avaliação (PASSOS, 2014).

A formulação engloba a formação de uma agenda, na qual será adotada como prioridade pública alguma necessidade social, a elaboração da política, ou seja, a identificação e delimitação do problema a ser tratado, bem como a escolha das alternativas modais e a avaliação dos custos e efeitos. Tal fase encerra-se quando a escolha de uma entre todas as alternativas existentes é formalizada por meio de uma norma jurídica (PASSOS, 2014).

A implementação envolve o planejamento e a organização do aparelho administrativo, englobando-se aí todos os fatores envolvidos: recursos humanos, materiais, tecnológicos e financeiros. Abrange, também, a execução e o acompanhamento das atividades estatais desenvolvidas para, ao final, permitir uma avaliação de todo esse processo e a análise dos efeitos produzidos na sociedade. Essas etapas nem sempre ocorrem de forma linear, sofrendo o influxo de inúmeros fatores que descredenciam qualquer pretensão de que sejam realizadas com base em critérios exclusivamente técnicos (PASSOS, 2014).

Para Passos (2014) o crivo judicial insere mais uma variável neste processo, mas o incrementa do ponto de vista democrático, na medida em que permite uma maior participação daqueles mais afastados dos centros de decisão, ao mesmo tempo que redireciona a atividade estatal para uma pauta mínima, representada pelo conteúdo substancial dos direitos fundamentais.

Cornejo (2002), tratando da inserção do Juiz no sistema político, mediante sua influência nas decisões democráticas, esclarece que os juízes passaram a exercer controle sobre todo o processo das políticas públicas, “[...] se antes podíamos restringir a atuação judicial à etapa de avaliação da política pública, agora a mesma se pratica sobre todas as etapas do processo, gerando assim uma participação constante dos juízes no processo de decisão que incide diretamente na formulação da política" (tradução nossa) ${ }^{52}$.

No entender de Passos (2014), a visão do magistrado e dos juristas em geral, no mais das vezes, é estreita em matéria de políticas públicas, por estar condicionado a um modelo

\footnotetext{
52 [...] si antes podíamos confinar la actuación judicial a la etapa de evaluación de la política pública, a hora la misma se practica sobre todas las etapas del proceso, gerando asi una participacion constante de los jueces em el proceso de decisión donde inciden diretamente em la formulacion misma de la policy (CORNEJO, Valentin Thury. Juez y division de poderes hoy. Madrid: Editorial Ciudad Argentina, 2002, p. 262).
} 
racional de análise dessas políticas, as quais entende o suficiente à identificação dos processos de montagem da agenda, desenho e meios de avaliação para a compreensão do perfeito desenvolvimento da atividade estatal. Segundo essa visão superficial:

[...] os formuladores da política devem: (1) conhecer todas as preferências valorativas da sociedade e seus respectivos pesos relativos; (2) conhecer todas as propostas disponíveis de políticas; (3) conhecer todas as consequências de cada proposta alternativa; (4) calcular os quocientes entre benefício/custo de cada proposta; (5) selecionar a proposta mais eficiente (DYE apud PASSOS, 2014, p. 98).

Indiscutivelmente, tal modelo dá nítidos contornos de previsibilidade ao processo de desenvolvimento das políticas públicas. Este enfoque, para o autor, é bastante incompleto, por desconsiderar outros inúmeros fatores aí incidentes, notadamente os de natureza política. As questões afetas ao poder extrapolam o caminho retilíneo supostamente percorrido pela prática pré-ordenada de atos, sofrendo todo tipo de influência por parte dos diversos interesses políticos. Tal influxo vai além das vias de participação popular institucionalizadas, tais como o plebiscito, o referendo e as comissões de caráter deliberativo (PASSOS, 2014).

Percebe-se, assim, a complexidade das políticas públicas, por não serem lineares, nem disporem de uma racionalidade manifesta, sofrem a influência de muitas variáveis, estando sujeita durante todo o seu ciclo a um conjunto de interações envolvendo múltiplos grupos de interesses, chegando alguns autores a defenderem que no âmbito das políticas públicas determinadas decisões, por serem eminentemente políticas, devem ficar a margem da interferência judicial.

A concretização dos direitos sociais dependerá tanto das escolhas políticas quanto dos recursos financeiros disponíveis pelo Estado. $\mathrm{O}$ acesso à saúde, mediante judicialização, vem imputando à administração pública sérios desafios na execução orçamentária dos recursos públicos. A relação entre orçamento público e políticas públicas é essencial, e apresenta caráter eminentemene político, conforme assevera Oliveira (2006, p. 246):

\footnotetext{
A decisão de gastar é, fundamentalmente, uma decisão política. O administrador elabora um plano de ação, descreve-o no orçamento, aponta os meios disponíveis para seu atendimento e efetua o gasto. A decisão política já vem inserta no documento solene de previsão de despesas.
}

Para Ana Paula de Barcellos (2005) o controle judicial das políticas públicas pode se dar mediante parâmetros objetivos, tais como aqueles apregados nos arts. 198, $2^{\mathrm{a}}$, e 212, da Constituição, que estipulam a aplicação de percentuais mínimos para as áreas de saúde e educação. Um segundo critério possível se relacionaria ao resultado final esperado pela atuação estatal, remetendo à questão da escolha de quais dentre todas as necessidades devem ser 
priorizadas, bem como a identificação de qual o grau mínimo de satisfação de direitos fundamentais exigível do Estado. Uma outra orientação diria respeito aos meios escolhidos pelo poder público para realizar as metas constitucionais. Aqui, a garantia de liberdade política do idealizador do programa restringiria a atividade judicial à eliminação exclusiva dos meios comprovadamente ineficientes.

Para Canela (2011) a intervenção judicial no campo das políticas públicas se destinaria a exigir a reparação de um direito ameaçado, lesado ou não garantido por meio de políticas públicas, mas não criaria programas ou estabeleceria a forma de sua execução, uma vez que o Poder Judiciário não dispõe de competência constitucional para criar programas ou estabelecer a forma de execução dos atos legislativos e administrativos para a efetivação dos direitos fundamentais.

É necessário fixar parâmetros, principalmente no que tange às ações individuais, uma vez que o desvio de fundos para tratamentos ou medicamentos determinados judicialmente, causa um impacto nos recursos destinados a política universalmente planejada, que certamente beneficiaria um grande número de pessoas.

O orçamento público é um importante instrumento de planejamento e transparência da administração pública, destinado a orientar o Governo nas várias etapas do processo administrativo: programação, execução e controle. No orçamento estão dispostos em termos de numéricos, as escolhas políticas que pretendem a consecução dos objetivos constitucionais.

A Lei 4.320/1964, que estabelece normas gerais de direito financeiro foi recepcionada pela Constituição Federal de 1988, esta instituiu a Lei do Plano Plurianual (PPA), a Lei de Diretrizes Orçamentárias (LDO) e a Lei Orçamentária Anual (LOA). Referidas leis se harmonizam $^{53}$ e se complementam e juntamente com a Lei de Responsabilidade Fiscal (LC $\mathrm{n}^{\circ} 101 / 2000$ ) devem ser observadas pelos governantes no tocante à realização de políticas públicas.

Dentre as incumbências do Poder Executivo figura a elaboração das leis orçamentárias (art.165, CF). A execução das políticas públicas demanda um planejamento orçamentário, pois a realização de dispêndios pelo Poder Público somente se dará diante de prévia autorização legislativa (princípio da legalidade da despesa pública), conforme dispõe o artigo 167, II, da Constituição Federal.

\footnotetext{
${ }^{53}$ Todos os planos e programas governamentais devem estar em harmonia com o plano plurianual, nos termos do art. $165, \S 4^{\circ}$ da Constituição Federal, e a LDO deverá estar em harmonia com o PPA, nos termos do art. 166, § $4^{\circ}$ da Constituição.
} 
Rocha (2011) defende que o princípio da legalidade da despesa pública não poderá impedir que o judiciário realize determinada prestação de saúde, ainda que não haja previsão orçamentária para essa despesa. No mesmo sentido, Grau (apud ROCHA, 2011) sustenta, inclusive, que quando houver confronto entre o princípio da legalidade da despesa pública e o princípio da sujeição da Administração às decisões do Poder Judiciário, este último sempre prevalecerá, devendo o Estado atender à ordem judicial.

Ocorre que, decisões judiciais que desconsideram a complexidade dos critérios normativos legais e a possibilidade da execução por meio dos recursos alocados no orçamento levam o administrador público a estar entre o desacato de uma decisão judicial e o cometimento de crime de responsabilidade ou crime contra a administração pública. Dessa forma, o administrador público torna-se passível punição conforme tipificado na Lei de Crimes Fiscais $n^{\circ} 10.028 / 00$, na Lei dos Crimes de Responsabilidade $n^{\circ} 1079 / 50$ ou na Lei 8.429/92, art.10, IX, caso ocorra a ordenação de despesas sem previsão orçamentária ou em montante superior ao previsto no orçamento.

Diante da necessidade do planejamento orçamentário para a execução de qualquer política pública de saúde, os “imprevistos” causados por determinadas decisões judiciais podem colocar em risco todo o planejamento orçamentário já definido para a realização das políticas de saúde, além de inviabilizarem a realização destas.

Bucci (2006) entende as ações coletivas como o meio por excelência de solução de conflitos envolvendo os direitos sistematizados em políticas públicas. No mesmo sentido, Pires (2011) ressalta que as controvérsias, com potencial de gerar maiores efeitos sistêmicos, como as relacionadas à tutela dos direitos prestacionais, devem ser levadas ao Judiciário pela via das ações coletivas ou objetivas, mais abertas à participação dos diversos interessados e à consideração global do tema e dos efeitos que a decisão pode produzir.

Todos os direitos possuem um custo e a proteção de direitos é afetada pela ausência de recursos do Estado. Sobre o tema, Sunstein e Holmes destacam na obra denominada "O custo dos direitos", que todos os direitos, mesmo aqueles que visam substancialmente resguardar a liberdade (tidos como direitos de defesa), são positivos e dependem da atuação estatal. Ainda conforme referidos autores: "nenhum direito cuja aplicação pressupõe um gasto seletivo de dinheiro dos contribuintes pode, no fim das contas, ser protegido pelo Judiciário sem considerar as consequências sobre as quais os outros poderes têm responsabilidade" (SUNSTEIN; HOLMES, 1999, p.19).

Diante da escassez de recursos orçamentários e da impossibilidade de efetivação de todos os direitos sociais fundamentais ao mesmo tempo, como forma de restringir a intervenção 
do Poder Judiciário em caráter absoluto, um argumento costuma ser invocado: a reserva do possível.

Marmelstein (2016) destaca que o postulado reserva do possível é fruto de uma construção jurisprudencial do Tribunal Constitucional Federal Alemão, que em resumo, significaria que os direitos às prestações podem ser exigidos judicialmente, cabendo ao Judiciário, observando o princípio da proporcionalidade, impor ao Poder Público as medidas necessárias à implementação do direito, desde que a ordem judicial fique dentro do financeiramente possível:

Nas palavras do Tribunal Constitucional Alemão, reserva do possível é aquilo que o indivíduo pode razoavelmente exigir da coletividade. Se for razoável (melhor dizendo, proporcional), não pode o Estado se negar a fornecer. Assim, pode-se dizer que a reserva do possível é sinônimo de razoabilidade econômica ou proporcionalidade financeira (Marmelstein, 2016, p.330) (grifos conforme o original).

No mesmo sentido, Mânica (2007, p.17), para quem as pretensões deduzidas perante o Poder Judiciário deverão ser analisadas mediante a ponderação de bens, com base no critério da proporcionalidade, aduz:

\footnotetext{
Nesse processo de ponderação, a racionalidade econômica - traduzida como limitação de recursos e de capacidade de disposição dos mesmos - incorpora-se à racionalidade do juiz, de modo a compor mais um elemento para determinação da proporcionalidade. Desse modo a ponderação deve levar em conta o pressuposto econômico de que as necessidades são limitadas e de que os recursos são escassos e a preocupação acerca do impacto econômico e social das decisões.
}

Marmelstein (2016) defende que o argumento da reserva do possível somente deve ser acolhido se o Poder Público demonstrar suficientemente que a decisão causará mais danos do que vantagens à efetivação dos direitos fundamentais. Vale enfatizar: o ônus da prova de que não há recursos para realizar os direitos sociais é do Poder Público. É ele quem deve trazer para os autos os elementos orçamentários e financeiros capazes de justificar, eventualmente, a não efetivação do direito fundamental.

Assim, a reserva do possível deve ser entendida sob o prisma da razoabilidade da reivindicação de efetivação de um direito social, ou seja, as pretensões devem ser analisadas pelo Poder Judiciário mediante a ponderação de bens, com base no critério da proporcionalidade. O custo para a efetivação de um direito fundamental não pode servir de obstáculo intransponível para sua efetivação, mas deve ser considerado no processo de ponderação.

No que tange às três regras da proporcionalidade: adequação, necessidade e proporcionalidade em sentido estrito, Rocha (2011) afirma que a adequação, impede ao 
Judiciário determinar que o Estado forneça a um indivíduo um medicamento que não seja indicado para o tratamento da doença acometida por este. A necessidade, por outro lado, veda ao Judiciário fornecer determinado medicamento não constante nas listas do Ministério das Saúde, caso haja outro medicamento igualmente eficaz e que esteja relacionado nas referidas listas.

Finalmente, a proporcionalidade em sentido estrito, que exige a ponderação entre os benefícios e prejuízos decorrentes da medida restritiva de direitos fundamentais, refere-se, por exemplo, às demandas que visam obrigar o ente público a proceder à imediata cirurgia de transplante, que não procedem pois o Judiciário não pode transgredir a lista de espera para o transplante de determinado órgão, que sacrificaria o direito de inúmeros outros indivíduos (ROCHA, 2011).

Na prática o que se vê sendo deferido nas demandas relativas a saúde são medidas que não obedecem a proporcionalidade em sentido estrito, uma vez que são cada vez mais recorrentes as liminares individuais que determinam a internação de um paciente em CTI de hospital público, sacrificando direitos de outros indivíduos que também necessitam de uma CTI e que em tese, por não possuírem determinação judicial sob pena de crime de desobediência e multa diária para a Administração, podem restar prejudicados.

Além disso, nas decisões referentes à saúde, há de se observar a reserva de consistência, entendida como o princípio da necessidade de fundamentação das decisões judiciais (FREIRE JUNIOR, 2005), que exige do juiz, ao efetivar uma norma constitucional, a necessidade de embasar sua decisão de modo convincente, utilizando-se não apenas de argumentos jurídicos, mas também de provas concretas, muitas vezes disponibilizadas por outras ciências, como laudos periciais e informações técnicas prestadas por médicos especialistas nas decisões que envolvam questões afetas ao direito fundamental à saúde. (ROCHA, 2011).

Há toda uma problemática envolvendo a judicialização individual do direito à saúde, que pode dar margem a preferências em sacrifício dos direitos de outrem, à defesa do interesse econômico de determinados agentes privados ou mesmo a um impacto importante em relação ao orçamento destinado ao atendimento dessas políticas públicas. É certo que a maioria dessas decisões exige uma maior capacidade institucional do órgão judicial, pois além de demandarem do julgador conhecimentos técnicos em matéria orçamentária, utilizando-se de uma razoabilidade econômica, suas decisões demandam conhecimento técnico também na área da saúde. 
A sessão seguinte, tratará de um argumento que pode nortear a redução da judicialização excessiva nessa área, ajudando na compreensão de que o judiciário deve assumir uma postura de autocontenção no pertinente a efetivação de políticas públicas em saúde no caso concreto.

\subsection{A Teoria da Capacidade Institucional e o ente mais competente para desenvolver políticas públicas em saúde}

Dentre as objeções opostas ao ativismo judicial estaria a falta de capacidade institucional do Judiciário para decidir determinadas matérias. Inicialmente, cabe definir os contornos deste argumento da forma como foi referido no artigo Interpretation e Institutions de Cass Sunstein e Adrian Vermeule, que o diferencia das conceituações já existentes no debate tradicional sobre a função judicial.

Em análise ao artigo referido, Arguelhes (2011) sustenta que a referência à capacidade institucional simplesmente como categorias teóricas ou dogmáticas já conhecidas, tais como "separação de poderes", "dificuldade contra majoritária" ou "discricionariedade técnica" é irrelevante, no sentido de que não agrega nenhum elemento novo. Ela expressaria, na verdade, a tomada de empréstimo de um rótulo novo e mais atraente para reposicionar no debate ideias e argumentos antigos.

Isso ocorre quando se diz, por exemplo, com base no texto de dispositivos constitucionais, que o Congresso Nacional tem mais "capacidade institucional" para elaborar normas gerais e prospectivas, ou que o Poder Executivo tem mais "capacidade institucional" para representar o país junto à comunidade internacional. Todas essas considerações podem ser verdadeiras. Entretanto, é difícil saber o que ganhamos ao formulá-las em termos de "capacidades institucionais", já que, aqui, a análise institucional se esgota em simples referências ao desenho formalmente expresso no texto constitucional (ARGUELHES, 2011, p.36).

Também seria equivocada sua utilização, para afirmar que o Judiciário tem menos capacidade institucional para resolver questões políticas, por não ser um poder eleito. Nesse caso, a expressão é usada como atalho para tratar da chamada "dificuldade contra majoritária" $(2011)^{54}$.

\footnotetext{
${ }^{54} \mathrm{O}$ autor relaciona o conceito "dificuldade contra majoritária" à "idéia(sic) de que, em um regime democrático, uma decisão judicial que vá contra juízos políticos, econômicos ou morais manifestados pelos poderes eleitos (Executivo e Legislativo) deve ser por definição encarada como suspeita, já que estaria subvertendo o rumo esperado do processo decisório em uma democracia".ARGUELHES, Diego Werneck; LEAL, Fernando. Argumento das "capacidades institucionais", entre a banalidade a redundância e o absurdo. Revista Direito, Estado e Sociedade, 38, 2011, p. 36.
} 
$\mathrm{O}$ argumento das capacidades institucionais proposto por Sunstein e Vermeule, no entender de Arguelhes (2011, p.40) se referiria "às habilidades e limitações de cada instituição para o exercício de suas funções em um cenário específico". Constituiria um pressuposto, à luz dos limites e capacidades do Poder Judiciário em si e em comparação com outras instituições, para a seleção de métodos de decisão mais apropriados nos quais juízes podem se orientar para interpretar textos e tomar decisões confiáveis.

Referido critério serviria para:

apreciar possíveis metodologias de tomada de decisão, e não como argumento de primeira-ordem voltado para criticar ou justificar decisões institucionais específicas. Pensar em capacidades institucionais, para os autores, significaria levar a sério as limitações e qualificações de uma determinada instituição no desenvolvimento de análises estáticas e dinâmicas relacionadas ao exercício de suas funções (ARGUELHES, 2011 p.41).

Outra concepção de capacidade institucional existente no cenário nacional, trazida por Barroso (2011), envolve a determinação de qual poder estaria mais habilitado a produzir a melhor decisão em determinada matéria. Essa concepção tem gerado afirmações como: O Poder Judiciário tem menos capacidade institucional de decidir questões técnicas complexas. Para Barroso (2011, p.236) "[...] temas envolvendo aspectos técnicos ou científicos de grande complexidade poderiam não ter no juiz de direito o árbitro mais qualificado, por falta de informação ou de conhecimento específico" ${ }^{25}$.

Arguelhes (2011) sustenta que a utilização do argumento com essa conotação não se assemelharia ao sentido proposto por Sunstein e Vermeule. Em casos como estes a perspectiva do autor continuaria focada em casos concretos e não no resultado agregado da atribuição, aos juízes, de competência para decidir determinadas questões. Na defesa do tema, aduz:

\footnotetext{
Parte-se de propriedades que se espera que essas instituições tenham, mas essa expectativa se funda em "tipos ideais" do Administrador e do Juiz. Não se investiga, por exemplo, quais os custos associados a se alocar essas questões técnicas exclusivamente para a Administração Pública, sem nenhum controle judicial. Uma teoria de tipo "second-best", analisa os custos associados à operacionalização, na prática, de várias alternativas decisórias diferentes, para então escolher aquela à que estão associados custos menores (sob um critério qualquer), mesmo que não seja a melhor em termos ideais.
}

\footnotetext{
${ }^{55}$ Acrescenta Barroso que, "em determinadas questões como demarcação de terras indígenas ou transposição de rios, em que tenha havido estudos técnicos e científicos adequados, a questão da capacidade institucional deve ser sopesada de maneira criteriosa, devendo o órgão judicial prestigiar as manifestações do Legislativo ou do Executivo, cedendo o passo para juízos discricionários dotados de razoabilidade". BARROSO, Luis Roberto. Constituição, democracia e supremacia judicial: Direito e Política no Brasil contemporêneo. As novas faces do ativismo judicial. Org. André Luiz Fellet, Daniel Giotti de Paula, Marcelo Novelino. Salvador: Editora Juspodivm, 2011, p. 236.
} 
Barroso (2011), contribuindo para o tema, alerta para o risco de efeitos sistêmicos imprevisíveis e indesejados das decisões, que recomendariam, em certos casos, uma posição de cautela e deferência por parte do Judiciário. O juiz, que está preparado para realizar a microjustiça, justiça no caso concreto, nem sempre dispõe das informações, do tempo e mesmo do conhecimento técnico para avaliar o impacto de determinadas decisões, proferidas em processos individuais, sobre a realidade de um segmento econômico ou sobre a prestação de um serviço público. Tampouco é passível de responsabilização política por escolhas desastradas.

O autor cita o setor da saúde como um exemplo emblemático, no qual, ao lado de intervenções necessárias e meritórias também haveria uma profusão de decisões extravagantes ou emocionais em matéria de medicamentos e terapias, que colocariam em risco a própria continuidade das políticas públicas de saúde, desorganizando a atividade administrativa e comprometendo a alocação dos escassos recursos públicos (BARROSO, 2011).

Nesse contexto, percebe-se a necessidade de que haja uma avaliação mais criteriosa por parte do magistrado da sua própria capacidade institucional e da capacidade de outras instituições, que possibilite sua autocontenção.

Parte do problema reside no fato de que o Magistrado, por não ser dotado de conhecimento técnico especificamente na área da saúde, pode até reconhecer que o Direito está sendo violado, mas não consegue operar de forma adequada os pedidos e tende a decidir conflitos na base do "tudo ou nada". Nesse aspecto, deve-se entender que o direito não pode ter a pretensão de resolver todos os problemas do mundo, seu escopo deve ser o de aliviar as expectativas. Ademais, não há verdades absolutas nas ciências em geral, quiçá no direito. É com base nessa consciência, de não auto-suficiência do direito, que o hermeneuta não pode pretender investir-se da condição de oráculo para resolver todas as mazelas que lhe são apresentadas, acreditando na possibilidade de descortinar nos textos normativos respostas para tudo (PASSOS, 2014).

Em direito, a resposta correta é aquela hermeneuticamente correta, ou seja, orientada, objetivamente pelos princípios e regras aplicáveis que consideram as peculiaridades do caso em concreto. Não é crível pensar que determinado texto normativo renderá, obrigatoriamente, uma única resposta possível, sendo natural a existência de diversas respostas para um mesmo problema interpretativo (PASSOS, 2014).

Ainda, para Passos (2014) a estratégia básica de raciocínio de quem leva as "capacidades institucionais" a sério, é a de que não se deve buscar algum tipo de solução ideal e recomendar que os órgãos decisores cheguem o mais próximo possível dela, mas sim que, comparando os 
custos associados a cada estado de coisas possível vinculado à implementação de diferentes alternativas em um dado cenário, busquem adotar a "segunda melhor" solução. Nesse sentido, a hipótese principal é a de que a chave para se compreender a especificidade e a relevância de um argumento baseado em capacidades institucionais reside na incorporação do que os economistas chamam de "second-best reasoning" nos debates sobre a adequação de posturas institucionais e métodos decisórios.

As escolhas do Poder Judiciário não podem ser analisadas como se as habilidades, limitações e o exercício das competências de juízes e tribunais se dessem em um vazio institucional. Quando criam ou tendem a criar tensões interinstitucionais, elas devem ser apreciadas relativamente aos méritos e deméritos das outras instituições também capazes de oferecer respostas para esses problemas (ARGUELHES, 2011)

Para Arguelhes (2016) o raciocínio pressuposto pelo argumento de capacidades institucionais poderia ser sintetizado a partir das seguintes características: uma comparação empiricamente informada sobre os custos e benefícios de se alocar no agregado, a prerrogativa de resolução de determinado problema a uma determinada instituição dentre várias instituições possíveis. Este cenário, como se vê, não comporta escolhas entre instituições feitas em abstrato.

Apesar dos desafios em se operacionalizar o argumento da capacidade institucional ${ }^{56}$, a percepção do conceito de Susten e Vermuele contribui para enfatizar a necessidade de uma reflexão do custo-benefício da satisfação do direito individual à saúde via judicial, prezando pela eficiência de decisões dentro de um locus repleto de possíveis instituições igualmente aptas a satisfação do direito pretendido, uma vez que casos, julgados concretamente e individualmente, podem causar efeitos sistêmicos prejudiciais de mais variadas espécies nesse campo, conforme se sustentou no início do presente capítulo.

$\mathrm{O}$ argumento da capacidade institucional, nos termos propostos por Sunstein e Vermeule, contribui à discussão da judicialização excessiva em matéria de saúde, uma vez que demonstra que a solução necessária à problemática das políticas públicas em saúde, não seja em termos ideais a intervenção judicial em um ou outro caso concreto, mas passa pela devida atenção e estudo do que outras instituições podem realizar em matéria de direitos fundamentais

\footnotetext{
${ }^{56} \mathrm{O}$ autor destaca que, dois desafios se apresentariam na operacionalização do argumento: 1) as capacidades de instituições específicas devem ser definidas concretamente, dentro de um arranjo institucional específico, não abstratamente, isso exigiria produção de informação, necessariamente contingente, sobre as capacidades concretas de todas as informações envolvidas; 2) mesmo que se faça uma aposta com as informações que se têm não há qualquer mecanismo para forçar juízes futuros a adotar o mesmo raciocínio e chegar à mesma análise comparativa de capacidades institucionais (ARGUELHES, Diego Werneck; LEAL, Fernando. Dois problemas de operacionalização do Argumento de "Capacidades Institucionais". Revista Estudos Institucionais, Vol.2, 1, 2016. p.210).
} 
e a comparação entre aos custos de se alocar a outras instituições ou a arranjos institucionais a realização desse direitos, o que pode contribuir para uma autocontenção e desjudicialização.

Ressalta-se que, no Brasil, a efetivação judicial do direito à saúde é tema de debate cada vez mais público e em diversos espaços. A análise e o desenho de uma política judiciária de saúde têm sido fomentados principalmente pelo Conselho Nacional de Justiça (CNJ) e envolve não somente a atuação das instituições jurídicas, como também sua inter-relação com instituições políticas e participativas (CNJ, 2015, p.10).

No próximo tópico, considerando a existência de duas espécies de judicialização em saúde e a necessidade de uma melhor fundamentação das decisões judiciais a respeito das ações individuais em saúde, expõe-se as estratégias de autocontenção já existentes no âmbito do Poder Judiciário, por iniciativa do Conselho Nacional de Justiça no desenvolvimento de uma política judiciária de saúde, como a criação dos NAT'S, comitês, normas, instruções, etc.

\subsection{Fundamentos Jurídicos do controle judicial sobre política pública de saúde: aspectos a serem considerados nas decisões judiciais}

A concretização dos direitos sociais depende tanto das escolhas políticas quanto dos recursos financeiros disponíveis pelo Estado. Ressaltando que em país nenhum do mundo existem recursos financeiros bastantes para atender sem limites, todas as exigências de todos quanto a satisfação plena dos direitos sociais, sendo necessário escolher qual parte dos recursos será destinado a cobrir essas despesas, Avelã Nunes defende que a necessidade de distribuição dos recursos financeiros destinados a atender esses direitos nos coloca no terreno das escolhas políticas, o que não caberia na competência dos tribunais (SCAFF; NUNES, 2011).

Especificamente quanto ao direito à saúde, ao aceitar-se que ele só pode se efetivar através de políticas públicas adequadas, as mesmas não poderiam ser reduzidas, ao contrário do ponto de vista que parece ser o dos tribunais brasileiros, à prestação de serviços médicos e ao fornecimento de meios de diagnóstico, intervenções cirúrgicas e medicamentos, segundo os interesses de cada pessoa que se encontre doente:

Os factores (sic) que condicionam a saúde das comunidades humanas são factores (sic) econômicos, sociais e culturais muito complexos, pelo que as políticas de saúde que devem atender a todos eles hão de ser necessariamente políticas complexas, que passam pela habitação, pela alimentação, pelo fornecimento de água potável, pelo saneamento básico, pela educação, pelo lazer, pela organização de serviços de cuidados primários de saúde, pela vacinação em massa, e que incluem também o funcionamento de hospitais onde se tratam os doentes com recurso aos meios de diagnóstico disponíveis a aos conhecimentos médicos, e a equipamentos 
tecnologicamente avançados e a medicamentos sofisticados (SCAFF; NUNES, 2011, p.37).

Considerando a política pública como decisão fundamentalmente política, existindo todo um processo político-administrativo de formulação e implementação, muitas decisões judiciais colocam os gestores em situação difícil, apesar de que ao magistrado não deveria ser possibilitado determinar à aqueles a aplicação de recursos financeiros do SUS para fins diversos, uma vez que constitui crime o emprego irregular dessas verbas (art.52, da Lei $\mathrm{n}^{\circ}$ 8.080/90 e art. 315, do Código Penal).

No presente tópico não se pretende analisar a competência institucional, nem a legitimidade do Poder Judiciário no enfrentamento da judicialização da saúde, tendo em vista o reconhecimento dessa possibilidade pelos tribunais pátrios, especialmente o STF, o que aqui inicialmente se expõe é a existência de dois tipos de judicialização da saúde.

A primeira hipótese se daria mediante a postulação judicial de exercício de direito já reconhecido, mas negado na via administrativa, que pode ser relativo a um medicamento, tratamento ou tecnologia já incorporados ao SUS ou no plano de saúde. Essa judicialização, que normalmente decorrente de falha no sistema ou problema de gestão, não gera inovação ou criação de política pública de saúde via judicial, sendo muito alto o índice de sucesso das demandas dessa natureza. Para alguns autores essas demandas deveriam ser resolvidas no plano extrajudicial, sem a intervenção do Poder Judiciário (SCHULZE; GEBRAN NETO, 2016, p.49$50)$.

A segunda ocorreria quando a discussão processual se referisse a direitos não reconhecidos na via administrativa, "tratamentos ou tecnologias ainda não incorporados, sem registro na Anvisa, sem comercialização no mercado nacional ou quando a tecnologia já está incorporada, mas o sujeito não possui indicação médica", nesses casos, o grau de rigorismo com o qual o processo deve ser analisado deve ser elevado, pois "condenações indevidas podem causar prejuízo financeiro muito grande e dificuldades na execução do planejamento orçamentário do ente público ou da operadora do plano de saúde" (SCHULZE; GEBRAN NETO 2016).

Em que pese os autores acima citados apresentarem críticas a segunda forma de judicialização, que em tese seria mais prejudicial à administração, tanto por invasão de competência, como pela questão orçamentária, as considerações a serem feitas a seguir se dirigem aos dois tipos de judicialização, pois se referem ao arcabouço legal e principiológico a ser observado em ambos os tipos de demanda. 
Inicialmente cumpre ressaltar que a própria Constituição Federal, prevê em seu art. 196, que o direito à saúde não é ilimitado, que a saúde é direito de todos e dever do estado, a ser garantido "mediante políticas sociais e econômicas". Ou seja, a primeira parte do dispositivo, deve ser lido de acordo com a segunda, que consagra o chamado princípio da ação política prioritária em saúde.

A Lei $n^{\circ} 8.080 / 90$ dá contornos mais estritos ao dever do Estado na garantia do direito à saúde, ao dispor no art. $2^{\circ}, \S 1^{\circ}$, que o mesmo "consiste na formulação de políticas econômicas e sociais que visem a redução de risco de doenças e de outros agravos e no estabelecimento de condições que assegurem acesso universal e igualitário às ações e aos serviços para a sua promoção, proteção e recuperação".

Além da ação política preventiva prioritária, um outro aspecto a ser observado relaciona-se a delimitação jurídica da saúde pública (art.196, CF/88), destinada ao atendimento do todos os indivíduos, que obedece a uma lógica distinta da saúde privada (art.170, CF/88). Enquanto a livre iniciativa a que é deixada a saúde privada obedece a uma lógica de lucro, de atendimento diferenciado e especializado, com liberdade de escolha por parte do paciente, sendo uma relação de confiança e contratual, não se pode exigir do sistema público de saúde qualidade igual ao que as pessoas da saúde suplementar tem acesso, na medida em que a CF/ 88 dispõe como objetivo do Estado constituir uma sociedade justa e solidária com diminuição das desigualdades sociais, só sendo possível exigir em tese do Estado o que já está previsto na política pública de saúde já existente ${ }^{57}$.

A Lei $\mathrm{n}^{\circ} 8.080 / 90, \operatorname{art}^{\circ}$, II, prevê expressamente como objetivo do Sistema Único de Saúde (SUS) a formulação da política de saúde, que o faz obedecendo a vários princípios, art. $7^{\circ}$, dentre eles: o da universalidade de acesso; da integralidade da assistência; igualdade de assistência; da utilização da epidemiologia para o estabelecimento de prioridades, a alocação de recursos e a orientação programática, dentre outros.

\footnotetext{
${ }^{57}$ Mapelly Júnior (2017) sustenta que: "O texto constitucional impede uma concepção consumista de saúde, conferindo-lhe status de direito social e 'relevância pública', sempre submetido a rigorosa regulamentação, fiscalização e controle do Poder Público(art.197), e vincula o seu exercício às políticas públicas (art.196, CF), mais adiante o autor acrescenta que "no desenho constitucional do SUS não há espaço para uma visão privatista, consumista e irrestrita de direito à saúde, como se se tratasse de um direito absoluto, sem regras, descolado dos protocolos clínicos e das diretrizes terapêuticas do Poder Público, dependente apenas da escolha do médico e do interessado, sem controle público. O SUS não pode servir para atender interesses meramente privados que não consideram, sob a ótica coletiva, os interesses ou direitos de outros que podem ser afrontados com o desvio de recursos orçamentários para procedimentos terapêuticos discutíveis, devendo os serviços públicos de saúde ser planejados para atender a todos, segundo escolhas prioritárias que consideram o perfil epidemiológico da população, os custos da tecnologia médica e os escassos recursos públicos, não interesses privados."(In MAPELLI JÚNIOR, Reynaldo. Judicialização da saúde: regime jurídico do SUS e intervenção na Administração pública. 1.ed. - Rio de Janeiro: Atheneu, 2017, p.65).
} 
Não somente com base nessas disposições, não há como se sustentar um direito à saúde ilimitado. Esta é a linha de entendimento adotada, também, por Figueiredo (2007, p.222), a seguir citada:

A fundamentalidade material e formal dos direitos sociais, contudo, não significa a
absolutização, nem tampouco uma eficácia ilimitada desses direitos. A incidência de
direitos fundamentais de terceiros; a escassez real dos recursos financeiros e fáticos
disponíveis à consecução dos direitos sociais; a adequação às regras constitucionais
de distribuição do poder, horizontal e verticalmente, ou seja, os princípios da
separação dos Poderes e da federação; as discriminações positivas a que se propõem
os direitos sociais, enquanto direitos dirigidos à superação, no 'ponto de chegada', das
diferenças fáticas que separam as pessoas; e a necessidade de concordância
harmônica, proporcional e razoável entre todas essas grandezas jurídica e
constitucionalmente relevantes, enfim, antepõem-se como objeções à efetivação dos
direitos sociais.

É inequívoco que se deve avançar na melhoria e incorporação de novas técnicas, procedimentos e medicamentos, mas os princípios da universalidade e integralidade não devem ser interpretados de forma equivocada.

A universalidade não deve ser interpretada com uma leitura rasa de que é para todos. Entender a universalidade de acesso aos serviços de saúde, em todos os níveis de prestação, pressupõe igualdade de assistência saúde; pois não se vislumbra como possa ser assegurado o acesso de todos (universalidade) às políticas sociais e econômicas voltadas para a salvaguarda da saúde, sem que ao mesmo tempo se garanta a equidade (igualdade) no atendimento, isenta de preconceitos ilegítimos ou privilégios 'nefastos'- discriminação ilícita (DUARTE, 2012).

A universalidade, portanto, deve ser entendida no sentido de que o Sistema Único não deve privilegiar exclusivamente determinado(s) usuário(s) em detrimento dos demais. Contudo, no presente artigo deter-se-á mais especificamente à integralidade, que por apresentar diversos sentidos, precisa de mais considerações de índole legal para que se encontre sua melhor hermenêutica.

A integralidade é tratada na Constituição Federal como uma diretriz para a organização do sistema único e elevada pelo art. 7º, I, da Lei n 8.080/1990 (Lei Orgânica da Saúde) à categoria de princípio orientador do Sistema Único de Saúde. O art. $7^{\circ}$, inciso II, da Lei Federal $\mathrm{n}^{\circ}$ 8.080/90, prega a "integralidade de assistência, entendida como conjunto articulado e contínuo das ações e serviços preventivos e curativos, individuais e coletivos, exigidos para cada caso em todos os níveis de complexidade do sistema”.

$\mathrm{O}$ atendimento integral de que trata o programa normativo do art.98, inciso II, da Constituição Federal, em nada tem a ver com atendimento ilimitado Carvalho (2006) considera que a integralidade na saúde apresenta duas dimensões, a vertical, que inclui a visão do ser 
humano como um todo, único e indivisível, onde não se examina o indivíduo apenas pela ótica da medicina curativa ou preventiva, mas o seu bem-estar físico, social e psíquico; e a horizontal, uma dimensão da ação de saúde em todos os campos e níveis de atenção.

O princípio da integralidade, que em um de seus sentidos relaciona-se ao emprego dos meios necessários para a efetivação do cuidado, de acordo com a complexidade das ações, parece ter um entendimento diferente para o Judiciário. Ao comparar a noção de integralidade empregada no Sistema Único de Saúde àquela manifestada mediante decisões dos tribunais, Vieira (2008, p.365-369) destaca que o deferimento de demandas sem a ressalvas sobre a existência de políticas públicas para tratar as doenças revela que a integralidade para os tribunais está mais associada a noção de consumo:

Nessa concepção, direito à saúde se resume a oferta de medicamentos, reduzindo-se
às ações curativas e paliativas, sem considerar o caráter fundamental de promoção e
prevenção de doenças e agravos. Sob esse ponto de vista, gera-se a confusão entre a
existência de mercado com a sua oferta de mais de 16 mil especialidades
farmacêuticas e a existência do SUS, que deve fornecer tratamento à população em
todos os níveis de complexidade de atenção à saúde (VIEIRA, 2008, p.365).

Para Miranda (2013, p. 29), o princípio da integralidade "consiste em oferecer uma carteira generosa de bens e serviços para a população, a partir de escolhas fundadas em consensos baseados em critérios científicos e racionais de escolha, validados socialmente, em princípios éticos, através de regras claras e transparentes".

No tocante a evolução jurisprudencial de dois tribunais superiores do país, STF e STJ, no que se refere ao direito à saúde, pode-se dizer que se divide em, pelo menos, três fases distintas do desenvolvimento da prática judiciária. Na primeira fase, iniciada em meados da década de 1990, denota-se a prevalência das teses da Fazenda Pública, no sentido da impossibilidade de atendimento estatal das demandas judicializadas relacionadas ao direito à saúde (BALESTRA NETO, 2015). ${ }^{58}$

Na segunda fase, com início em 2000, a jurisprudência predominante passou a se filiar a um novo entendimento, identificando a fundamentalidade material do direito à saúde, como emanação direta do princípio da dignidade da pessoa humana, os tribunais superaram as várias teses defensivas da Fazenda Pública, fazendo assim valer, indiscriminadamente, os pedidos dos usuários do Sistema Único de Saúde. Nesse período os ministros passaram a se debruçar

\footnotetext{
${ }^{58}$ Como exemplo ilustrativo dessa fase, o autor aponta o Recurso em Mandado de Segurança n. 6564/RS, julgado pelo STJ, em 23 de maio de 1996. (In BALESTRA NETO, Otávio. A Jurisprudência dos tribunais superiores e o direito à saúde - Evolução rumo à racionalidade. Revista de Direito Sanitário, São Paulo, v.16, n.1, p. 87-111, mar./jun. 2015).
} 
basicamente sobre o conflito entre mínimo existencial e reserva do possível, sem lançarem maiores considerações sobre as especificidades do pedido (BALESTRA NETO, 2015). ${ }^{59}$

Finalmente, uma terceira fase iniciou-se em meados da década de 2000, quando os tribunais eventualmente passaram a negar pedidos ligados ao direito fundamental à saúde, analisando as questões próprias das ações - medicamentos fora da lista nacional, medicamentos experimentais etc. Nessa ocasião, tribunais superiores começaram a superar a ideia de que o direito à saúde e sua diretriz da integralidade significariam um "direito a tudo", passando a uma análise mais minudente do caso concreto, com considerações de ordem técnica. Inaugurou-se na jurisprudência uma série de decisões negando aos usuários do SUS determinadas prestações, por estarem em desacordo com balizas das políticas públicas previamente delineadas $\left(\right.$ BALESTRA NETO, 2015) ${ }^{60}$.

A decisão do STF em grau recursal, relativa ao pedido de Suspensão de Tutela Antecipada STA n. 175 AgR/CE, que teve como relator o Min. Gilmar Mendes, 17.03.2010, intentada contra acórdão proferido pela $1^{\text {a }}$ Turma do Tribunal Regional Federal da $5^{\text {a }}$ Região, nos autos da Apelação Cível no 408729/CE (2006.81.00.003148-1), traçou importantes balizas para julgados sobre o tema.

Nessa decisão, com fulcro no art. 196, CF/88, se reconhece a existência de um direito público subjetivo a políticas públicas que promovam, protejam e recuperem a saúde, não havendo, contudo, direito absoluto a todo e qualquer procedimento que recupere a saúde.

$\mathrm{O}$ Ministro relator, devido à grande quantidade de processos e complexidade envolvida, convocou Audiência Pública no 04 para ouvir especialistas em matéria de saúde pública e após oitiva dos depoimentos, constatou que, na maioria das demandas, a intervenção judicial não ocorre em razão de uma omissão absoluta em matéria de políticas púbicas voltadas

\footnotetext{
${ }^{59}$ Exemplos elucidativos dessa posição jurisprudencial são seguintes julgados: o Recurso Extraordinário $\mathrm{n}$. 195192/RS e o Agravo Regimental no Recurso Extraordinário n. 271286/RS, ambos do STF, e o Recurso em Mandado de Segurança n. 11183/RS, do STJ. (In BALESTRA NETO, Otávio. A Jurisprudência dos tribunais superiores e o direito à saúde - Evolução rumo à racionalidade. Revista de Direito Sanitário, São Paulo, v.16, n.1, p. 87-111, mar./jun. 2015).

${ }^{60}$ Acrescenta o autor que: "Esse novo momento da jurisprudência brasileira culminou com a audiência pública de 2009, no STF, que levou, finalmente, à estipulação de parâmetros bem mais nítidos para a racionalização da prática judiciária do direito à saúde. São exemplos dessa fase jurisprudencial: o Mandado de Segurança n. 8895/DF, do STJ, a Suspensão de Segurança n. 3073 e o Agravo Regimental na Tutela Antecipada n. 175, os dois últimos do STF. Pode-se dizer que esta terceira fase gerou ao menos três eventos importantes para a judicialização da saúde no Brasil: (a) a realização da audiência pública no STF, em 2009; (b) o julgamento do Agravo Regimental na Suspensão de Tutela Antecipada n. 175, em 17 de março de 2010; e (c) a edição da Lei no 12.401/2011". (In BALESTRA NETO, Otávio. A Jurisprudência dos tribunais superiores e o direito à saúde - Evolução rumo à racionalidade. Revista de Direito Sanitário, São Paulo, v.16, n.1, p. 87-111, mar./jun. 2015).
} 
a promoção do direito à saúde, mas com a finalidade de obter tutela judicial para o cumprimento de políticas já estabelecidas.

Cita-se como parâmetro inicial para as decisões, a observância de existir ou não política estatal que abranja a prestação de saúde pleiteada pela parte. Caso a prestação não esteja entre as políticas do SUS, deve-se distinguir se a não prestação decorre: 1) de uma omissão legislativa ou administrativa; 2) de uma decisão administrativa de não fornecê-la; ou 3) de uma vedação legal a sua dispensação. Sendo vedado à Administração fornecer fármaco que não possua registro na Anvisa, nos termos da Lei Federal nº 6.360/76.

Um segundo dado a ser considerado seria a existência de motivação para o não fornecimento de determinada ação de saúde pelo SUS, considerando que em alguns casos, o SUS decide não custear por entender que inexistem evidências científicas ${ }^{61}$ suficientes para autorizar sua inclusão. Nessas hipóteses, poderiam ocorrer duas situações: "1º o SUS oferece tratamento alternativo, mas não adequado a determinado paciente; $2^{\circ}$ ) o SUS não tem nenhum tratamento específico para determinada patologia."

Sobre a matéria, o Ministro Gilmar Mendes acentuou que, em geral, deve ser privilegiado o tratamento fornecido pelo SUS em detrimento de opção diversa escolhida pelo paciente, sempre que não for comprovada a ineficácia ou a impropriedade da política de saúde existente, de modo que cabe ao usuário o ônus da prova da ineficácia do tratamento oferecido pelo SUS. No julgamento também restou assentado que:

[...] que a inexistência de Protocolo Clínico no SUS não pode significar violação ao princípio da integralidade do sistema, nem justificar a diferença entre as opções acessíveis aos usuários da rede pública e as disponíveis aos usuários da rede privada". Nesses casos, a omissão administrativa no tratamento de determinada patologia poderá ser objeto de impugnação judicial, tanto por ações individuais como coletivas. No entanto, é imprescindível que haja instrução processual, com ampla produção de provas, o que poderá configurar-se um obstáculo à concessão de medida cautelar. (SUPREMO TRIBUNAL FEDERAL, 2010)

\footnotetext{
${ }^{61}$ A Medicina Baseada em Evidências (MBE) originou-se da "nova ciência resultante da associação dos métodos da epidemiologia com a pesquisa clínica", vindo a coroar os conceitos fundamentais da Medicina e da Saúde, que requerem "evidências de eficácia, efetividade, eficiência e segurança para nortear decisões, tendo-se assim maior probabilidade de se acertar". (in ATALLAH, Álvaro Nagib. Medicina baseada em evidências. Revista Diagnóstico \& Tratamento. v. 23, ed.02, São Paulo: 2018, p.43-44). Schulze considera a Medicina Baseada em Evidências MBE como melhor instrumento para identificar a eficácia, a eficiência, a segurança e o custo-efetividade de produtos e medicamentos. É a partir dos estudos do Medicina Baseada em Evidências (MBE) que surgem os Protocolos de Diretrizes Terapêuticas(PCDTs) e as decisões e notas técnicas da Comissão Nacional de Incorporação de Tecnologia(CONITEC), da Agência Nacional de Vigilância Sanitária(Anvisa), da Agência Nacional de Saúde Suplementar (ANS) e do Instituto Cochrane, entre outros: "à luz do princípio da integralidade, que norteia a relação médico-sujeito, é recomendável que sejam utilizadas as medidas já adotadas no SUS para, apenas na hipótese de insucesso, cogitar-se a indicação de tratamento não incorporado no SUS." (in SCHULZE, Clenio Jair. Enunciados do CNJ sobre saúde pública. Parte I e II. Revista Empório do Direito, 2016. Disponível em: <http://emporiododireito.com.br/leitura/enunciados-do-cnj-sobre-saude-publica-parte-i-por-clenio-jairschulze>Acesso em: 05 out 2018.
} 
O presente caso resolvido pelo STF é um retrato fiel de que houve uma evolução jurisprudencial dos tribunais superiores, tendo chegado mais próximo do ponto de equilíbrio existente entre as infinitas demandas dos usuários e a necessidade de organização e racionalidade do SUS (BALESTRA NETO, 2015).

Schulze (2016) aborda critérios que os juízes do Brasil teriam de observar para proferir decisões judiciais sobre direito à saúde, especialmente nos casos de alto impacto para o gestor, que teria como objeto de conflito, por exemplo, a internação compulsória, concessão de tratamentos, medicamentos ou tecnologias ainda não incorporados, entre outros, a fim de evitar excessos inconstitucionais.

As alterações que a Lei $n^{\circ}$ 12.401/2011 introduziu na Lei ${ }^{\circ}$ 8.080/1990 estabelecem regras sobre a assistência terapêutica e disciplinam a incorporação de novas tecnologias no âmbito do Sistema Único de Saúde-SUS. Essa lei traz como importantes inovações: 1) a constituição da Comissão Nacional de Incorporação de Tecnologia do SUS - CONITEC ${ }^{62}$, que tem o papel de desenvolver estudos técnicos para assessorar o Ministério da Saúde na incorporação de novas tecnologias e 2) a necessidade de observância de alguns requisitos à incorporação de novas tecnologias no âmbito do SUS, devendo-se observar a existência de evidências científicas sobre a eficácia, a acurácia, a efetividade e a segurança do medicamento, produto ou medicamento objeto do processo de incorporação; bem como indispensável a avaliação econômica comparativa dos benefícios e dos custos em relação às tecnologias já incorporadas, inclusive no que se refere aos atendimentos domiciliar, ambulatorial ou hospitalar, quando cabível (SCHULZE; GEBRAN NETO, 2016).

Para referido autor, a autoridade judicial responsável por processo em que se postula a concessão de medicamento, tratamento ou tecnologia deve observar as decisões baseadas em critérios técnicos proferidas pela CONITEC, se a decisão dessa comissão é favorável à incorporação daquela tecnologia, o magistrado não poderia contrariá-la, salvo comprovação científica contrária, contemporânea ou superveniente (ônus que compete ao autor do processo). De outro lado, se a posição da CONITEC for a de não autorizar a tecnologia no âmbito do SUS,

\footnotetext{
${ }^{62}$ Sua composição deverá contemplar um representante indicado pelo Conselho Nacional de Saúde e de um representante, especialista na área, indicado pelo Conselho Federal de Medicina, as decisões da CONITEC são divulgadas em seu sítio eletrônico, e na ausência de decisão técnica na via administrativa, a autoridade judiciária poderá se valer de consulta, inclusive via e-mail(conitec@ saude.gov.br), sobre produtos e tecnologias postulados judicialmente (In SCHULZE, Clenio; GEBRAN NETO, João Pedro. Direito à saúde à luz da judicialização. Porto Alegre: Verbo Jurídico, 2016, p.65-66).
} 
o juiz somente poderia deferir o pedido se houver prova técnica (apresentada pela parte autora) refutando a conclusão da CONITEC (SCHULZE; GEBRAN NETO, 2016).

A decisão judicial destituída de fundamentação fática é nula, por descumprir o comando do art.93, IX, da Constituição. Não basta apenas mencionar que o direito à saúde está garantido na Constituição, a partir do art. $5^{\circ}$ e do art.196. É necessário que, na análise do caso judicializado, se investigue o diagnóstico, o quadro clínico e principalmente, a comprovação da melhor prática de evidência científica, além da eficácia, da acurácia, da efetividade e da segurança o medicamento, produto ou procedimento postulado, sem dispensar também, a avaliação econômica comparativa dos benefícios e dos custos em relação às tecnologias já incorporadas, que consistiria na análise da relação custo-benefício ${ }^{63}$ (SCHULZE; GEBRAN NETO, 2016).

Outras balizas para o controle judicial, adotadas a partir, mas não exclusivamente da decisão proferida na STA n ${ }^{\circ}$ 175, são enumeradas por Gebran Neto (2016). Como premissa inicial, referido autor postula que haverá direito subjetivo público à saúde quando existir política pública que preveja o fornecimento de determinado medicamento e/ou tratamento ao cidadão, sendo exigível perante o Poder Público o seu fornecimento e seu deferimento deve ocorrer por intermédio do próprio SUS, em concordância com o Enunciado $n^{\circ} 11$, da I Jornada da Saúde:

\begin{abstract}
Enunciado $\mathrm{n}^{\circ} 11$ - Nos casos em que o pedido em ação judicial seja de medicamento, produto ou procedimento já previsto nas listas oficiais do Sistema Único de Saúde (SUS) ou em PDCT, recomenda-se que seja determinada, pelo Poder Judiciário, a inclusão do demandante em serviço ou programa já existentes no SUS, para fins de acompanhamento e controle clínico.
\end{abstract}

Uma segunda premissa identificada pelo autor é que por força do princípio da universalidade se faz desnecessária a comprovação da hipossuficiência para fazer jus a prestação material, esteja ela fixada em política pública ou não. A terceira premissa refere-se à vedação legal de dispensação de medicamento não aprovado pela Anvisa, contida na Lei $n^{\circ}$

\footnotetext{
${ }^{63}$ Schulze ressalta (2016, p. 68) a necessidade da adequação dos juízes e tribunais ao tema, sob pena de prolatação de decisão não baseada em critérios científicos, que pode colocar em risco a segurança do beneficiário e ao próprio sistema de saúde - público e suplementar. Mais adiante, o autor exemplifica com suposto equívoco de decisão do próprio Supremo Tribunal Federal, no Recurso Extraordinário 3685664, que tratou da retinose pigmentar, concedendo a várias pessoas o direito de obter tratamento em Cuba, com todas as despesas custeadas pelo Estado, mesmo inexistindo no processo comprovação científica da eficácia e da efetividade do tratamento, pelo contrário, foi apresentado laudo indicando ausência de cura. Mesmo assim, o voto do Ministro condutor Marco Aurélio, afirmou que existia sim tratamento exitoso em Cuba conforme informação que obteve nos veículos de comunicação. "Tal decisão demonstra a forma inadequada como são analisados os processos judiciais sobre saúde. É impossível imaginar que uma decisão judicial seja proferida com base em informação jornalística e não à luz do sistema jurídico." (In SCHULZE, Clenio; GEBRAN NETO, João Pedro. Direito à saúde à luz da judicialização. Porto Alegre: Verbo Jurídico, 2016, p. 68-104)
} 
8.080/90, alterada pela Lei $\mathrm{n}^{\circ}$ 12.401/11, conforme art. 19-T, II, que estabelece (SCHULZE; GEBRAN NETO, 2016, p. 176) ${ }^{64}$ :

Art. 19-T. São vedados, em todas as esferas de gestão do SUS:

[...] II - a dispensação, o pagamento, o ressarcimento ou o reembolso de medicamento e produto, nacional ou importado, sem registro na Anvisa."

Especificamente quanto a medicamentos, o Superior Tribunal de Justiça (STJ) recentemente definiu requisitos para a concessão dos medicamentos não incorporados em atos normativos do SUS, nos autos do RESP n ${ }^{\circ}$ 1.657.156/RJ - Tema 106, entendendo, para fins do artigo 1.036, do Código de Processo Civil, ser exigível a presença cumulativa dos seguintes requisitos: (i) comprovação, por meio de laudo médico fundamentado e circunstanciado expedido por médico que assiste o paciente, da imprescindibilidade ou necessidade do medicamento, assim como da ineficácia, para o tratamento da moléstia, dos fármacos fornecidos pelo SUS; (ii) incapacidade financeira de arcar com o custo do medicamento prescrito; (iii) existência de registro na ANVISA do medicamento ${ }^{65}$.

Outra premissa consistiria na necessidade de prévio requerimento administrativo, sendo possível o ajuizamento da ação judicial somente após a decisão administrativa, ou

\footnotetext{
${ }^{64}$ Em sintonia com o presente artigo, encontram-se os enunciados $n^{\circ} 6$ e $9^{\circ}$, da I Jornada da Saúde: Enunciado $n^{\circ}$ 6 - A determinação judicial de fornecimento de fármacos deve evitar os medicamentos ainda não registrados na Anvisa, ou em fase experimental, ressalvadas as exceções expressamente previstas em lei. [...] Enunciado $n^{\circ} 9$ As ações que versem sobre medicamentos e tratamentos experimentais devem observar as normas emitidas pela Comissão Nacional de Ética em Pesquisa (Conep) e Anvisa, não se podendo impor aos entes federados provimento e custeio de medicamento e tratamentos experimentais.

${ }^{65}$ Assim se pronunciou a Corte Superior: “Administrativo. Recurso Especial representativo de controvérsia. TEMA 106. Julgamento sob o rito do art. 1.036 do CPC/2015. Fornecimento de medicamentos não constantes dos atos normativos do SUS. Possibilidade. Caráter excepcional. Requisitos cumulativos para o fornecimento. 1. Caso dos autos: A ora recorrida, conforme consta do receituário e do laudo médico (fls. 14-15, e-STJ), é portadora de glaucoma crônico bilateral (CID 440.1), necessitando fazer uso contínuo de medicamentos (colírios: azorga 5 ml, glaub $5 \mathrm{ml}$ e optive $15 \mathrm{ml}$ ), na forma prescrita por médico em atendimento pelo Sistema Único de Saúde - SUS. A Corte de origem entendeu que foi devidamente demonstrada a necessidade da ora recorrida em receber a medicação pleiteada, bem como a ausência de condições financeiras para aquisição dos medicamentos. 2. Alegações da recorrente: Destacou-se que a assistência farmacêutica estatal apenas pode ser prestada por intermédio da entrega de medicamentos prescritos em conformidade com os Protocolos Clínicos incorporados ao SUS ou, na hipótese de inexistência de protocolo, com o fornecimento de medicamentos constantes em listas editadas pelos entes públicos. Subsidiariamente, pede que seja reconhecida a possibilidade de substituição do medicamento pleiteado por outros já padronizados e disponibilizados. 3. Tese afetada: Obrigatoriedade do poder público de fornecer medicamentos não incorporados em atos normativos do SUS (Tema 106). Trata-se, portanto, exclusivamente do fornecimento de medicamento, previsto no inciso I do art. 19-M da Lei $\mathrm{n}^{\circ}$ 8.080/1990, não se analisando os casos de outras alternativas terapêuticas. 4. TESE PARA FINS DO ART. 1.036 DO CPC/2015. A concessão dos medicamentos não incorporados em atos normativos do SUS exige a presença cumulativa dos seguintes requisitos: (i) Comprovação, por meio de laudo médico fundamentado e circunstanciado expedido por médico que assiste o paciente, da imprescindibilidade ou necessidade do medicamento, assim como da ineficácia, para o tratamento da moléstia, dos fármacos fornecidos pelo SUS; (ii) incapacidade financeira de arcar com o custo do medicamento prescrito; (iii) existência de registro na ANVISA do medicamento. 5. Recurso especial do Estado do Rio de Janeiro não provido. Acórdão submetido à sistemática do art. 1.036 do CPC/2015.” (STJ - Resp 1657156/RJ, Rel. Ministro Benedito Gonçalves, primeira seção, julgado em 25/04/2018, DJe 04/05/2018).
} 
omissão desta em apresentar resposta fundamentada em tempo razoável, premissa que também se sustenta em enunciado do CNJ (SCHULZE; GEBRAN NETO, 2016, p. 183):

Enunciado $n^{\circ} 13$ - Nas ações de saúde, que pleiteiam do poder público o fornecimento de medicamentos, produtos ou tratamentos, recomenda-se, sempre que possível, a prévia oitiva do gestor do Sistema Único de Saúde (SUS), com vistas a, inclusive, identificar solicitação prévia do requerente à Administração, competência do ente federado e alternativas terapêuticas.

Além disso, o tratamento para diferentes patologias devem ser realizadas, no âmbito do SUS, obedecendo as diretrizes fixadas pela política pública, ressalvando-se a hipótese de “demonstração de sua inadequação ou ineficácia para o paciente, sendo vedado o tratamento ou medicamento experimental" (SCHULZE; GEBRAN NETO, 2006, p.186), esse requisito está em consonância com os enunciados $\mathrm{n}^{\circ} 14$ e 16 da referida Jornada:

Enunciado $\mathrm{n}^{\mathrm{o}} 14$ - Não comprovada a inefetividade ou impropriedade dos medicamentos e tratamentos fornecidos pela rede pública de saúde, deve ser indeferido o pedido não constante das políticas públicas do Sistema Único de Saúde (SUS). [...]

Enunciado $\mathrm{n}^{\circ} 16$ - Nas demandas que visam ao acesso a ações e serviços da saúde diferenciada daquelas oferecidas pelo Sistema Único de Saúde (SUS), o autor deve apresentar prova da evidência científica e também a inexistência, inefetividade ou impropriedade dos procedimentos ou medicamentos constantes dos protocolos clínicos do SUS.

Para o Gebran Neto (2016) é necessária a realização de laudo médico (ou perícia, sendo aquele preferível) indicando, se for o caso, a necessidade de tratamento excepcional, seus efeitos, estudos da Medicina Baseada em Evidências (MBE) e vantagens para o paciente, além da comparação com eventuais fármacos fornecidos pelo SUS. A preocupação com a adoção de critérios científicos quanto à adequação do tratamento/medicamento proposto evidencia-se através da leitura do seguinte enunciado da I Jornada da Saúde:

Enunciado $\mathrm{n}^{\circ} 17$. Sempre que possível, as decisões liminares sobre saúde devem ser precedidas de notas de evidência científica emitidas por Núcleos de Apoio Técnico em Saúde (NATS).

Finalmente, deve ser de conhecimento do público a existência de eventual conflito de interesses ${ }^{66}$ entre o prescritor e o fármaco prescrito, consistente na obrigação do médico que prescreve determinado medicamento informar se participou na criação ou desenvolvimento do

\footnotetext{
${ }^{66}$ Destaque-se que o conflito de interesses tem sido objeto de constante preocupação do Conselho Federal de Medicina, que vem regulando a matéria. "O Código de Ética Médica (17 de setembro de 2009), a Resolução 196/96 do Conselho Nacional de Saúde, a Resolução da Diretoria Colegiada- RDC 96/2008 da Agência Nacional de Vigilância Sanitária e a Resolução 1.595/2000 do Conselho Federal de Medicina fazem menção a diferentes modos de conflitos de interesses". (In SCHULZE, Clenio; GEBRAN NETO, João Pedro. Direito à saúde à luz da judicialização. Porto Alegre: Verbo Jurídico, 2016, p. 189).
} 
fármaco, ou se participou de eventuais cursos, estudos, pesquisas, viagens, congressos, palestras ou outros eventos financiados pelo laboratório ou indústria farmacêutica (SCHULZE; GEBRAN NETO, 2006).

Tais premissas e a orientação jurisprudencial que delas se seguiu, para o autor, não tem respondido satisfatoriamente a diversas questões, pois as exceções previstas na STA $\mathrm{n}^{\circ} 175$ têm prevalecido sobre as teses centrais. No que se refere especificamente as decisões que deferem medicamentos, uma rápida pesquisa sobre a jurisprudência nacional permite verificar que são raras as decisões que não os deferem, tendo o paciente demonstrado minimamente a necessidade, bastando existir uma prescrição de médico particular, indicando o princípio ativo, o nome fantasia ou qualquer outra indicação do fármaco ${ }^{67}$ (SCHULZE; GEBRAN NETO, 2006).

Duarte (2012, p.396) defende que nem todo argumento é válido em sede de discursos jurisdicionais de aplicação, alguns deles, na verdade, em vez de reforçarem a correção das decisões judiciais, terminariam por subvertê-las em novos e anômalos discursos de fundamentação "propiciando ao juiz uma liberdade argumentativa incompatível com uma concepção pós-positivista do direito e com a própria pretensão de desenvolvimento e consolidação de um Estado Democrático de direito".

Quanto as decisões afetas ao Direito Fundamental à saúde, essa questão seria particularmente problemática, pois como fundamentação interna do provimento jurisdicional do pedido, é bastante usual encontrar argumentos do tipo:

[...] 'se o Estado não prestar o tratamento a pessoa vai morrer'(a), 'o medicamento é eficaz ao tratamento da patologia e, por isso, o Estado não pode se furtar a prestá-lo ao paciente'(b), 'como a saúde é Direito e dever de todos, nos termos do art.196 da $\mathrm{CR} / 88$, este não pode deixar de custear o tratamento em fase experimental, pleiteado por pessoa carente'(c). (DUARTE, 2012, p.396)

Algumas perguntas que ajudariam a fornecer uma solução correta para o caso concreto como na demanda por medicamentos, seriam:

\footnotetext{
${ }^{67}$ Conclui o autor: "De regra, não se exige maiores provas quanto a exames médicos, demonstração de que a pretensão está fundada na medicina baseada em evidências, prévio requerimento administrativo ou mesmo prescrição por médico do SUS. Sequer a demonstração do efetivo benefício do fármaco ou sua comparação com similares ou com aqueles previstos na política pública. Grande parte das decisões judiciais limita-se a analisar a urgência do paciente, comprovação da moléstia e a necessidade indicada pela prescrição de um médico especialista, num raciocínio reducionista de que 'ninguém postula judicialmente um medicamento se dele não estiver precisando”. (In SCHULZE, Clenio; GEBRAN NETO, João Pedro. Direito à saúde à luz da judicialização. Porto Alegre: Verbo Jurídico, 2016, p. 192).
} 
[...] 'por que o Estado se negou a fornecer o medicamento?' a); 'o remédio de fato é eficiente para o tratamento da patologia?' (b); 'existem similares que poderiam ser empregados com o mesmo fim e que podem ser fornecidos pelo SUS?' (c); 'o que diz a comunidade científica nacional e internacional acerca do medicamento pleiteado?' (d); 'o procedimento de incorporação descambou para argumentos ilegítimos à luz de uma leitura holística do sistema jurídico e da Constituição como locus hermenêutico do Direito?'[...] (DUARTE, 2012, p.396).

Duarte (2012) ressalta a importância de investigar de forma mais aprofundada alguns dos programas normativos relacionados com o Direito à saúde, e que, direta ou indiretamente, refletem nas dimensões de conteúdo que seu âmbito normativo pode vir a assumir, permitindo enxergar com mais clareza a complexidade da definição, in concreto, do âmbito normativo do Direito à saúde, a fim de não pressupor um Direito à saúde 'sem qualquer limite fático', o que não se sustenta em nenhum lugar do mundo.

Outro parâmetro que poderia ser levado em consideração para decisões envolvendo saúde pública especificamente, diz respeito a possibilidade do Estado conferir a todos os cidadãos o pedido pleiteado judicialmente, pois, de acordo com o princípio da universalidade de assistência, o magistrado deveria questionar se seria economicamente viável ao ente adotar determinada ação em saúde como política estatal, face também o caráter coletivo do direito à saúde.

Quanto ao tema, cumpre ressaltar considerações do Min. Gilmar Mendes na decisão proferida em sede de tutela coletiva, Suspensão de Liminar 228-7/CE ${ }^{68}$. Para Duarte (2012), que elogia referida decisão, a mesma revela a necessidade de um redimensionamento da questão da judicialização dos direitos sociais no Brasil. Referido ministro foi enfático ao dizer que:

[...] por ser assegurado principalmente mediante políticas públicas sociais e econômicas, não haveria um direito absoluto a todo e qualquer procedimento necessário para a proteção, promoção e recuperação da saúde, independentemente da existência de uma política pública que viessem a concretizá-lo. Em todo caso, segundo ele, haveria um direito público subjetivo a políticas públicas que promovessem, protegessem e recuperassem a saúde. [...]

Segundo Gilmar Mendes, em casos tais, o primeiro aspecto a ser considerado seria a existência ou não de política estatal que abrangesse a prestação de saúde pleiteada pela parte no processo. Em sua opinião, ao deferir uma prestação de saúde que estivesse incluída entre as políticas sociais e econômicas formuladas pelo SUS, o judiciário não estaria criando uma nova política pública, mas determinado seu efetivo cumprimento. Nesses casos, a existência de um direito subjetivo público a determinada política de saúde seria evidente.

Por outro lado, se a prestação pleiteada não fosse abrangida pelas políticas do SUS, seria imprescindível distinguir se a não prestação decorria de uma omissão legislativa ou administrativa(a), ou de uma decisão administrativa de não fornecer(b). Nesses casos, na visão do Ministro, 'a ponderação dos princípios em conflito' daria a resposta

\footnotetext{
${ }^{68}$ Referido Pedido de Suspensão de Liminar foi manejado pela União, contra decisão proferida pelo Juiz da $18^{\mathrm{a}}$ Vara Federal de Sobral, no julgamento de ACP proposta em conjunto pelo Ministério Público Federal e do Ministério Público do Estado de Ceará, que buscava garantir à população dos 61 municípios da MacrorregiãoAdministrativa de Sobral, o acesso aos serviços médicos de urgência necessários ao tratamento intensivo, em casos de grave risco a saúde, a decisão havia sido mantida pelo TRF da $5^{\text {a }}$ Região.
} 
para o caso concreto. No fim, caso chegasse a conclusão pelo dever de 'determinar o fornecimento de um serviço de saúde(internação hospitalar, cirurgias, medicamentos, etc.)' o julgador precisaria assegurar-se de que o Sistema de Saúde 'possuiria condições de arcar não só com as despesas da parte, mas também com as despesas de todos os outros cidadãos que se encontrassem em situação idêntica'. (DUARTE, 2016, p.428) grifo nosso

Mapelli Júnior (2017) sustenta que a única forma de compatibilizar o direito individual com os princípios da universalidade, igualdade (e/ou equidade) e da integralidade (sistêmica ou regulada) seria que as ações judiciais de tutela individual se restringissem a medicamentos e produtos tipicamente sanitários previstos nos programas do SUS; cabendo ao Ministério Público e demais instituições legitimadas por lei, discutir judicialmente as políticas públicas de medicamentos, seus protocolos clínicos e as diretrizes terapêuticas, sob pena de se incorrer no privilégio da disponibilização de nova tecnologia médica de forma individual. ${ }^{69}$

Dentre os dispositivos infraconstitucionais aplicáveis no âmbito da saúde pública, se encontram: a Lei $n^{\circ} 8.080 / 1990$, a Lei $n^{\circ} 12.401 / 2011$, Decreto $n^{\circ} 7.508 / 2011$, Lei $n^{\circ}$ 8.142/1990, Resoluções no 1931/2009, n 1956/2010 e no 2156/2016 do Conselho Federal de Medicina, Portarias $\mathrm{n}^{\mathrm{o}} 1.897 / 2017,1.554 / 2013,1.555 / 2013$ do Ministério da Saúde, Enunciados na $1^{\mathrm{a}}$ e $2^{\mathrm{a}}$ Jornadas do Direito da Saúde.

Nenhum juiz possui poderes absolutos, mas não se pode negar, que diante do caso concreto, muitos deles ficam reféns de pedidos fundamentados em prescrições médicas que violam as regras da medicina baseada em evidências. Como os juízes não tem formação na área médica, o Poder Judiciário passou a fornecer instrumentos aos juízes do Brasil para facilitar a compreensão desse tema. A crescente qualificação dos profissionais do direito sobre o tema, as iniciativas do Conselho Nacional de Justiça, os trabalhos desenvolvidos pelo Fórum Nacional do Judiciário para a Saúde e as atividades dos diversos Comitês Estaduais de Saúde tendem a

\footnotetext{
${ }^{69}$ Como providências complementares para as ações individuais, sugere-se que: a) antes de apreciar a medida de urgência requerida, o magistrado consulte os gestores do SUS, inclusive por meio eletrônico, para saber se existe programa público disponível; como o paciente deve proceder para ingressar no SUS e qual a alternativa terapêutica pública, afastando prescrições privadas irregulares; b) deve exigir como documento mínimo a instruir a inicial relatório médico circunstanciado do caso, que indique o diagnóstico da doença (CID) e o medicamento por princípio ativo ou denominação genérica, doses e periodicidade do tratamento; o receituário deve indicar a existência de registro do medicamento ou produto na ANVISA, declarar que não se trata de tratamento experimental ou dependente de importação; c) a instrução probatória deve contar, pelo menos, com as versões dos gestores do SUS e do paciente-autor e a realização de perícia médica que pode ser proveniente do NAT(Núcleo de Apoio Técnico do Judiciário), além de informações técnicas complementares, provenientes de conselhos regionais(medicina, farmácia, etc.), universidades e centros de medicina baseada em evidências(Centro COCHHRANE); por se tratar de ação versando sobre direito individual com repercussão em políticas públicas do SUS, faz-se necessário manifestação do Ministério Público como custo legis;d) havendo condenação, o magistrado deve determinar o ingresso do paciente na rede pública do SUS, bem como o cumprimento dos procedimentos técnico-administrativos do programa de medicamentos correspondente; devendo também determinar que as compras públicas sigam as regulamentações da CMED, especialmente o desconto CAP, por se tratar de produtos fármacos decorrentes de ação judicial. (In MAPELLI JÚNIOR, Reynaldo. Judicialização da saúde: regime jurídico do SUS e intervenção na Administração pública. 1.ed. - Rio de Janeiro: Atheneu, 2017, p.177-178).
} 
facilitar uma alteração do conteúdo da judicialização da saúde (SCHULZE; GEBRAN NETO, 2016, p. 193).

Desde 2009, os casos ligados a judicialização da saúde são acompanhados pelo Conselho Nacional de Justiça (CNJ), quando este promoveu a primeira audiência pública para discutir o tema. Um dos principais resultados da referida audiência foi a constituição de um grupo de trabalho, mediante Portaria n ${ }^{\circ} 650$ de 20 de novembro de 2009 do CNJ, composto por juízes federais e estaduais, desembargadores e especialistas em Direito Sanitário, responsável por estudar e propor medidas concretas e normativas para as demandas judiciais envolvendo a assistência em saúde, no âmbito do próprio CNJ (MACEDO, 2016, p.106).

Atos normativos provenientes do Conselho Nacional de Justiça (CNJ), como a Recomendação n 31/2010 e a Recomendação no 36/2011, abordam a adoção de medidas para subsidiar os magistrados nas decisões sobre saúde pública e suplementar.

Considerando o expressivo volume processual, através da Recomendação n ${ }^{\circ}$ 31/2010, o CNJ estimulou que os tribunais, entre outras medidas, celebrassem convênios com o objeto de disponibilizar apoio técnico composto por médicos e farmacêuticos para auxiliá-los na apreciação das questões clínicas apresentadas pelas partes, observadas as peculiaridades regionais. $^{70}$

Através da Resolução no 107/2010, ficou instituído o Fórum Nacional do Judiciário para monitoramento e resolução de demandas de assistência à saúde, com objetivo de monitorar as demandas assistenciais e discutir estratégias para efetivar o Direito à saúde. Na I Jornada do Direito da Saúde, em maio de 2014, o CNJ aprovou 45 enunciados (19 de saúde pública, 17 de saúde suplementar e 9 de biodireito), a seleção dos enunciados foi feita pelo Comitê Executivo Nacional do Fórum de Saúde e pela Comissão científica do evento, alguns deles já foram citados.

\footnotetext{
${ }^{70} \mathrm{Além}$ disso, estabeleceu que os magistrados: 1) procurem instruir as ações, tanto quanto possível, com relatórios médicos, com descrição da doença, inclusive CID, contendo prescrição de medicamentos, com denominação genérica ou princípio ativo, produtos, órteses, próteses e insumos em geral, com posologia exata; 2) evitem autorizar o fornecimento de medicamentos ainda não registrados pela Anvisa, ou em fase experimental, ressalvadas as exceções expressamente previstas em lei; 3) ouçam, quando possível, preferencialmente por meio eletrônico, os gestores, antes da apreciação de medidas de urgência; 4) incluam a legislação relativa ao direito sanitário como matéria no programa de direito administrativo dos respectivos concursos para ingresso na carreira da magistratura, além de incorporar o direito sanitário nos programas dos cursos de formação, vitaliciamento e aperfeiçoamento de magistrados; 5) promovam visitas dos magistrados aos Conselhos Municipais e Estaduais de Saúde, bem como às unidades de saúde pública ou conveniadas ao SUS, dispensários de medicamentos e a hospitais habilitados em Oncologia como Unidade de Assistência de Alta Complexidade em Oncologia (Unacon) ou Centro de Assistência de Alta Complexidade em Oncologia (Cacon) (Recomendação nº 31/2010).
} 
A II Jornada da Saúde do CNJ, que ocorreu em maio de 2015, com o slogan "A justiça faz bem à saúde”, também deu origem a importantes enunciados, recomendando, por exemplo: a requisição do prontuário médico para tornar a prova mais fidedigna com a situação do paciente (Enunciado $\mathrm{n}^{\circ}$ 49); para a caracterização de urgência/emergência, relatório médico circunstanciado, com menção expressa ao quadro clínico de risco imediato (Enunciado $\mathrm{n}^{\circ}$ 51); que em processo judicial no qual se pleiteia o fornecimento de medicamento, produto ou procedimento, verifique-se se a questão foi apreciada pela Comissão Nacional de Incorporação de Tecnologias no SUS - CONITEC (Enunciado $\mathrm{n}^{\mathbf{0}}$ 57); quando houver prescrição de medicamento, produto, órteses, próteses ou procedimentos que não constem em lista (RENAME/RENASES) ou protocolo do SUS, notifique-se da ação judicial o médico prescritor, para esclarecimentos sobre a pertinência e necessidade da prescrição, bem como para firmar declaração de eventual conflito de interesse (Enunciado $\mathrm{n}^{\circ} 58$ ); que as demandas por procedimentos, medicamentos, próteses, órteses e materiais especiais, fora das listas oficiais, sejam fundadas na Medicina Baseada em Evidências (Enunciado nº 59).

Os enunciados do CNJ são provenientes de decisões proferidas pelas Turmas Recursais. Apesar de não se tratar de legislação, visam unificar um entendimento que seja recorrente nos tribunais, evitando-se a insegurança jurídica (CORVINO, 2017, p. 182). Resta saber se nas decisões judiciais atualmente são consideradas as Recomendações do CNJ, bem como referidos enunciados, o que conferiria um grande ganho técnico nas decisões, uma vez que as mesmas possibilitam uma judicialização da saúde mais coerente com os princípios e diretrizes do Sistema Único de Saúde.

Portanto, a lógica que vem sendo empregada na Judicialização da saúde, limitando-se a interpretação da saúde como "direito de todos e dever do Estado", merece uma melhor interpretação. Os enunciados não só do CNJ, mas dos Comitês de saúde, vem procurando organizar a discussão sobre o tema. Afinal a valorização das escolhas públicas é indispensável para uma equitativa distribuição de bens e recursos na área da saúde.

Com a judicialização da saúde, diferentes aspectos científicos passam a ser exigidos, direta ou indiretamente dos atores do sistema de justiça. Para tanto se faz muito importante o conhecimento, pelos magistrados, de protocolos clínicos e diretrizes terapêuticas ${ }^{71}$ e da

\footnotetext{
${ }^{71}$ Conforme definição do Ministério da saúde: “Observando ética e tecnicamente a prescrição médica, os PCDTs tem o objetivo de estabelecer os critérios de diagnósticos de doenças, o algorítimo de tratamento com os medicamentos e as doses adequadas, os mecanismos para o monitoramento clínico quanto à efetividade do tratamento e a supervisão de possíveis efeitos adversos, além de criar mecanismos para a garantia da prescrição segura e eficaz. Além de nortearem uma assistência médica e farmacêutica efetiva e de qualidade, os PCDTs auxiliam os gestores de saúde nas três esferas de governo, como instrumento de apoio na disponibilização de procedimentos e na tomada de decisão quanto à aquisição e dispensação de medicamentos tanto no âmbito da
} 
medicina baseada em evidências, que muitas vezes vem a desempenhar papel preponderante na solução do litígio.

Percebe-se que as incursões judiciais podem ser muito mais coerentes com a forma com a qual o Sistema Único se organiza, dotando as decisões de mais legitimidade, na medida em que possam se fundamentar em recomendações e enunciados que passaram por um debate com outros atores e setores responsáveis pela Saúde Pública como um todo.

Vê-se que essas decisões terão um grande ganho de fundamentação, desde que a magistratura esteja mais preparada para atuar nesses casos, seja mediante cursos de aperfeiçoamento, ou assessoria por profissionais de saúde, o que vai contribuir para uma autocontenção e, consequentemente, redução da judicialização excessiva, nas duas formas em que elas se apresentam.

No próximo tópico, tratar-se-á da questão da judicialização no Estado do Ceará e se exporá estratégias de autocontenção desenvolvidas com o envolvimento de diversos atores do sistema judicial e sistema de saúde.

\subsection{A Judicialização da saúde no Estado do Ceará: um esforço pela autocontenção judicial}

No Estado do Ceará um tipo de demanda que causa apreensão principalmente por, em tese, ferir o acesso igualitário à política de saúde pública, relaciona-se aos leitos de UTI. Diante da negativa do Poder Público, inúmeros indivíduos recorrem ao Judiciário para garantir uma vaga e o embate ocorre quando a decisão judicial viola a ordem de uma fila de espera. No estado, esse problema é objeto de noticiários desde 2003, quando foi ajuizada ação civil pública para transferência de pacientes de fila para a rede privada, bem como a construção de mais leitos; diante da permanência do problema, outras ações civis públicas foram ajuizadas, além de diversas demandas individuais (LEITE, 2016).

Conforme recente estudo, do intervalo de tempo entre 2013 até outubro de 2014, houve aumento na quantidade de demandas enviadas à Crifor ${ }^{72}$. Enquanto durante todo o ano de 2013

atenção primária como no da atenção especializada, cumprindo um papel fundamental nos processos de gerenciamento dos programas de assistência farmacêutica, na educação em saúde, para profissionais e pacientes, e, ainda nos aspectos legais envolvidos no acesso a medicamentos e na assistência como um todo." (In MINISTÉRIO DA SAÚDE. Protocolos Clínicos e Diretrizes terapêuticas. Série A. Normas e manuais técnicos. Vol.1, Brasília; 2010).

${ }^{72}$ Impende informar que a fila de espera para internação em leito de UTI no Estado do Ceará é organizada pela Unisus, da Secretaria Estadual da Saúde, através da Central de Regulação do SUS do Estado do Ceará (CresusCE). Já no município de Fortaleza, essa fila é organizada pela Crifor, órgão vinculado à Secretaria Municipal de Saúde, por intermédio do Sistema de Regulação(Sisreg) e da Central integrada de Regulação de Fortaleza(Cirf). 
(365 dias), houve um total de 75 mandados judiciais, em um intervalo inferior no ano seguinte, até o dia 31 outubro de 2014 (304 dias), a Crifor recebeu 202 mandados, o que demonstrou um crescente aumento nesse tipo de demanda. Para Leite (2016), isso evidencia a necessidade de uma ação macroscópica para o problema, com a utilização de ação coletiva, notadamente, a ação civil pública (ACP).

Em resposta à ação civil pública (ACP) ajuizada pela Defensoria Pública da União (DPU) em dezembro de 2014, a Justiça Federal determinou, em outubro de 2017, a implantação de, no mínimo, 150 novos leitos de Unidade de Terapia Intensiva (UTI) no sistema público de saúde do Ceará, que devem ser implantados de forma conjunta e solidária pela União, Estado do Ceará e municípios de Fortaleza e Caucaia, no prazo máximo de quatro anos contados do ajuizamento da demanda, sendo que, a cada ano, deverão ser implantadas no mínimo 35 novas $\operatorname{vagas}^{73}$

Contudo, a judicialização desses casos ainda vem tomando grandes proporções. Somente o Núcleo de Defesa da Saúde (NUDESA) da Defensoria Pública do Estado do Ceará recebe diariamente, de 10 a 15 pedidos de pessoas em busca de vagas em leitos de Unidades de Terapia Intensiva (UTI) nos hospitais da rede pública. No ano de 2017, a entidade deu entrada em cerca de 600 solicitações desta natureza, sendo 277 no segundo semestre ${ }^{74}$.

Em outro estudo, que aborda a judicialização do direito à saúde no Estado do Ceará, através do cruzamento de dados de processos judiciais nos sistemas de informação do judiciário entre os anos de 1998 e 2012, também se verificou a tendência de ampliação do processo de judicialização no Ceará. Dentre os processos analisados, a demanda por medicamentos representou 74\% dos pedidos; linfoma, doença pulmonar obstrutiva crônica (DPOC), mieloma e diabetes equivaleram sozinhas a $31 \%$ de todas as doenças, sendo que as prescrições médicas, em sua maioria $(76 \%)$ eram provenientes da rede pública. Dentre outros achados relevantes, os autores constataram que:

a) $963(99,8 \%)$ processos solicitaram tutela antecipada, dos quais em $882(91,4 \%)$ o pedido foi deferido e em 35 (3,6\%) o pedido estava pendente. Portanto, em apenas 46 $(4,7 \%)$ dos processos os magistrados não haviam concedido a tutela antecipada. Além disso, nos 882 processos que tiveram a tutela antecipada concedida, em $858(97,3 \%)$

(In LEITE, Vanessa Gomes Leite. Reflexos da judicialização da saúde no acesso igualitário à políticas públicas: a questão dos leitos de UTI no Estado do Ceará. Dissertação de Mestrado. Universidade Federal do Ceará, Faculdade de Direito, Programa de Pós-Graduação em Direito, Fortaleza, 2016, p. 130)

${ }^{73}$ Disponível em: <http://www.dpu.def.br/noticias-ceara/39886-acao-da-dpu-garante-implantacao-de-150-novosleitos-de-uti-no-ceara>. Acesso em: 30 out 2018.

74 Disponível em: <http://diariodonordeste.verdesmares.com.br/editorias/metro/defensoria-solicita-de-10-a-15pedidos-de-vaga-em-uti-por-dia-1.1920384>. Acesso em: 30 out 2018. 
as medidas antecipatórias foram concedidas sem que se ouvisse a administração pública (inaudita auterapars).

b) grande divergência de dados entre os dados encontrados na pesquisa: 1.757 processos encontrados por pesquisa direta, enquanto os dados oficiais divulgados pelo CNJ, colocavam o Ceará como o quarto maior Estado do país em número de demandas, e maior do Nordeste, com 8.344 processos em judicialização da saúde;

c) a maioria dos medicamentos pleiteados é aprovada pela Agência Nacional de Vigilância Sanitária (ANVISA) (RAMOS JÚNIOR, NUNES, 2016, p. 192).

De uma análise sobre a judicialização das políticas públicas de saúde na Justiça Federal, especialmente no que diz respeito ao fornecimento de medicamentos no âmbito do Tribunal Regional Federal da $5^{\text {a }}$ Região, mediante a seleção de acórdãos disponíveis no sítio eletrônico de referido TRF, referentes ao fornecimento de medicamentos de alto custo, no período compreendido entre 2007 a 2014, entre outros achados, revelou-se que:

1) dos seis estados da Federação integrantes do Tribunal Regional Federal da $5^{\mathrm{a}}$ região, o maior número de ações concentrou-se no estado do Rio Grande do Norte $(34,2 \%)$ seguidos por Ceará $(24,7 \%)$, Pernambuco (21,4\%), Alagoas (9,7\%), Paraíba $(5,3 \%)$ e Sergipe $(4,6 \%)$;

2) há uma presença pouco significativa de ações de natureza coletiva $(2,4 \%)$ ou com efeitos coletivos $(1,7 \%)$, prevalecendo ações de natureza individual.

3) existe uma tendência do tribunal em conceder pedidos de medicamentos não constantes na lista do SUS, desconsiderando argumentos levantados pela defesa no tocante à observância de políticas públicas já existentes.

4) na maior parte das decisões, não há uma análise criteriosa da adequação, necessidade e proporcionalidade da medida, limitando-se a prover as ações sem considerar os possíveis impactos sociais e econômicos que a judicialização pode causar (82,3\%) (PASSOS; GOMES, 2017, 105).

Dentre as medidas que buscam uma redução e aprimoramento no julgamento das demandas em saúde no âmbito do Estado, cumpre ressaltar, que em cumprimento à Resolução de $n^{\circ} 238$ de 06/09/2016 do CNJ, que trata sobre a criação e manutenção, pelos Tribunais de Justiça e Regionais Federais, de Comitês Estaduais da Saúde, foi instalado, no dia 22 de março de 2011, o Comitê Executivo em Saúde do Estado do Ceará, sendo atualmente composto por representantes de diferentes órgãos (Justiça Federal, Justiça Estadual, Ministério Público Federal, Ministério Público Estadual, Defensoria Pública da União, Defensoria Pública do Estado, Procuradoria do Estado do Ceará, Procuradoria do Município de Fortaleza, Ordem dos Advogados do Brasil - Seção Ceará, Secretaria da Saúde do Estado do Ceará, Secretaria de Saúde do Município de Fortaleza, Representantes das Operadoras dos Plano de Saúde, Agência Nacional de Saúde Suplementar - Núcleo Ceará, Conselho Regional de Medicina, AGU, Representante dos usuários da saúde suplementar) que voluntariamente cumulam estas atividades com os seus respectivos trabalhos profissionais ${ }^{75}$.

\footnotetext{
${ }^{75}$ Disponível em: <https://www.tjce.jus.br/saude/criacao/>. Acesso em: 01 dez 2018.
} 
O Comitê Estadual da Saúde tem entre as suas atribuições, apresentar propostas às instâncias competentes para implementação e regulamentação de políticas públicas e acompanhar sua execução, inclusive emitindo recomendações; articular e mobilizar a sociedade e o poder público por meio de campanhas, debates e de ações; estimular a produção de estudos, pesquisas, debates e campanhas; implementar e monitorar ações previstas nos planos nacional, estadual e municipais de saúde, estimulando o desempenho de órgãos e entidades, avaliando os resultados; acompanhar os trabalhos dos poderes legislativos estadual e municipais quanto a projetos de leis referentes às ações de saúde; participar da elaboração da política e os planos estadual e municipais de saúde e firmar termos de acordo de cooperação técnica ou convênios com órgãos e entidades públicas e privadas, cuja atuação institucional esteja voltada à busca de solução dos conflitos na área de saúde ${ }^{76}$.

Visando contribuir para o monitoramento e resolução das demandas de assistência à saúde, com a atribuição de elaborar estudos e propor medidas concretas e normativas para o aperfeiçoamento de procedimentos, a efetividade dos processos judiciais e a prevenção de novos conflitos, o trabalho do referido comitê deu origem a duas Recomendações no âmbito do Tribunal de Justiça do Estado do Ceará, a Recomendação no 01/2017, que dispõe sobre a utilização do relatório médico para ajuizamento de ações em matéria de saúde suplementar e a Recomendação de $\mathrm{n}^{\circ}$ 02/2017, que dispõe sobre a utilização do relatório médico para ajuizamento de ações em matéria de saúde pública, recomendando:

I) À Defensoria Pública da União no Ceará, à Defensoria Pública Estadual do Ceará, à Ordem dos Advogados do Brasil - Secção Ceará, aos Procuradores da República no Estado do Ceará, aos Promotores de Justiça do Ministério Público do Estado do Ceará, aos Magistrados, aos Servidores Públicos e aos demais profissionais que direta ou indiretamente atuam nas tutelas inerentes ao Direito de Saúde a solicitarem dos médicos vinculados ao Sistema Único de Saúde o preenchimento do Relatório Médico para Judicialização no âmbito da Saúde Pública, anexo a esta Recomendação, aprovada pelo Comitê Executivo da Saúde do Estado do Ceará;

II) À Secretaria Estadual de Saúde, às Secretarias Municipais de Saúde do Ceará e à EBSERH $^{77}$ que diligenciem no sentido de dar conhecimento aos profissionais prescritores, através de capacitação específica, acerca da existência do Relatório Médico para Judicialização no âmbito da Saúde Pública, com o auxílio do Conselho Regional de Medicina do Estado do Ceará, na divulgação e capacitação dos profissionais $^{78}$.

O Tribunal de Justiça do Estado do Ceará, tendo como referências legislativas o art. 196, da Constituição Federal, e o art. $2^{\circ}$, caput, $\S 1^{\text {o }}$, da Lei ${ }^{\circ} 8.080 / 90$ firmou entendimento

\footnotetext{
${ }^{76}$ Disponível em: <https://www.tjce.jus.br/saude/criacao/>. Acesso em: 01 dez 2018.

${ }^{77}$ Empresa Brasileira de Serviços Hospitalares.

${ }^{78}$ Disponível em

$<$ https://www.tjce.jus.br/wp-content/uploads/2017/10/Minuta-deRecomenda\%C3\%A7\%C3\%A3o-Relat\%C3\%B3rio-M\%C3\%A9dico-Sa\%C3\%BAde-P\%C3\%BAblica-1.pdf $>$. Acesso em: $01 \mathrm{dez} 2018$.
} 
na Súmula $n^{\circ} 45$, de que "Ao Poder Público compete fornecer a pacientes tratamento ou medicamento registrado no órgão de vigilância sanitária competente, não disponibilizado no sistema de saúde"79.

Dentre as capacitações que o Comitê Estadual de Saúde tem proporcionado aos atores da saúde, destaque-se, em outubro de 2017, o Curso de "Capacitação em saúde suplementar", que reuniu Judiciário, ANS e operadoras de planos ${ }^{80}$, e em agosto de 2018, palestra sobre "A regulação dos leitos no Estado do Ceará”, aberta à participação de magistrados ${ }^{81}$.

O Comitê Estadual de Saúde ainda tem como função auxiliar os tribunais na criação de Núcleos de Apoio Técnico do Judiciário (NAT'S), constituído de profissionais da Saúde, para elaborar pareceres acerca da medicina baseada em evidências, observando-se na sua criação o disposto no parágrafo segundo do art. 156 do Código de Processo Civil Brasileiro. Os Núcleos de Apoio Técnico do Judiciário (NAT'S) terão função exclusivamente de apoio técnico, auxiliando os magistrados que precisam decidir sobre demandas que chegam à Justiça e envolvem temas relacionados à saúde. Sobre a instalação do referido no Núcleo no Estado do Ceará se tratará ao longo do quarto capítulo da presente dissertação.

No próximo capítulo, inicialmente analisa-se resultado de pesquisa Jurisprudencial desenvolvida no âmbito do Tribunal de Justiça do Estado do Ceará com finalidade de traçar um panorama da judicialização, com o objetivo de conhecimento das ações judiciais, quanto a suas especificidades, bem como sobre a fundamentação das decisões judiciais, concessivas ou não desses direitos. Em seguida, aborda-se a teoria dos diálogos institucionais e suas contribuições para uma cultura de desjudicialização da saúde pública, para finalmente se estudar as estratégias que contam com o diálogo entre os atores da política de saúde e da justiça, desenvolvidas o âmbito do Estado do Ceará.

\footnotetext{
${ }^{79}$ Precedentes: Agravo de instrumento 0032134-29.2009.8.06.0000 Órgão Julgador: $1^{a}$ Câmara Cível decisão: 10/10/2012; Agravo de instrumento 0016794-45.2009.8.06.0001 Órgão Julgador: $3^{\text {a }}$ Câmara Cível decisão: 19/12/2012; mandado de segurança 0018777-55.2004.8.06.0000 Órgão Julgador: Órgão especial decisão: 27/06/2011. (In Regimento interno do Tribunal de Justiça do Estado do Ceará. Fortaleza: Tribunal de Justiça do Estado do Ceará, 2018, p.203-204. Disponível em: <https://www.tjce.jus.br/wpcontent/uploads/2015/07/Regimento-Interno-TJCE-2018-28Miolo29-Final.pdf>. Acesso em: 05 dez 2018.

${ }^{80}$ Disponível em <https://www.tjce.jus.br/noticias-saude/comite-encerra-curso-de-saude-suplementar-reunindojudiciario-ans-e-operadoras-de-planos/>Acesso em: 01 dez 2018.

${ }^{81}$ Disponível em <https://www.tjce.jus.br/noticias/a-regulacao-de-leitos-no-ceara-e-tema-de-palestra-paramagistrados-nesta-sexta-feira/>. Acesso em: 05 dez 2018.
} 


\section{A JUDICIALIZAÇÃO DA SAÚDE NO ÂMBITO DO TRIBUNAL DE JUSTIÇA DO ESTADO DO CEARÁ NO ANO DE 2017 E O DIÁLOGO INSTITUCIONAL COMO ALTERNATIVA AO EXCESSO DE JUDICIALIZAÇÃO NA SAÚDE PÚBLICA}

O presente capítulo apresenta como objetivo inicial descrever e analisar o panorama da judicialização da saúde no Estado do Ceará no ano de 2017, através de uma estratégia metodológica que utilizar-se-á de técnicas quantitativas e qualitativas de produção, coleta e análise de dados. A pesquisa será exploratória e desenvolvida com base na análise jurisprudencial no âmbito do Tribunal de Justiça do Estado do Ceará, com a finalidade de construir um perfil dos litígios em saúde pública, buscando categorizá-los mediante variáveis como: autor, réu, bem de saúde demandado, existência da antecipação de tutela, argumentação da decisão judicial, ações coletivas e individuais.

Este estudo se funda na necessidade de ampliar o debate sobre a judicialização da saúde na circunscrição do Estado em análise, visto a carência de estudos específicos sobre a matéria; sendo escolhido o Tribunal de Justiça do Estado do Ceará (TJCE), pois no seu âmbito houve recentemente a adoção de uma política de desjudicialização resultando, por exemplo, na instalação do NAT-JUS/CE.

Impende ressaltar que se terá como campo específico a saúde pública porque se visa demonstrar como a política pública está organizada em ampla gama normativa, em contraste com a análise muitas vezes simplória que tem sido feita por determinados tribunais para deferir demandas em saúde, visando observar se o mesmo ocorre no âmbito do Tribunal de Justiça do Estado do Ceará (TJCE).

Assim, a fim de proporcionar uma melhor compreensão da judicialização em saúde, o objetivo do presente estudo consiste em realizar uma análise descritiva das decisões judiciais proferidas em segunda instância pelo Tribunal de Justiça do Estado do Ceará no ano de 2017, que envolveram o Sistema Único de Saúde e o seu cumprimento por parte deste órgão, restringindo-se as demandas que envolvam saúde pública.

Espera-se que este estudo contribua para o conhecimento sobre as ações judiciais, podendo-se verificar tanto as especificidades dessas necessidades assistenciais, bem como a fundamentação das decisões judiciais, concessivas ou não desses direitos.

Após descrever o panorama da judicialização da saúde no Estado do Ceará, se discorrerá acerca dos arranjos institucionais adotados para promoção no Estado da autocontenção judicial em matéria de saúde pública e da sua efetiva contribuição para o enfrentamento da excessiva judicialização. 


\subsection{Diagnóstico da Judicialização em saúde no Tribunal de Justiça do Estado do Ceará}

Diante do que foi exposto ao longo dos capítulos anteriores, cabem as mais diversas indagações a respeito da Judicialização da Saúde no Estado do Ceará. Através da pesquisa jurisprudencial que se segue, busca-se determinar, por exemplo, se as demandas são proeminentemente de natureza individual, que tipo de judicialização é mais buscada (se a que o indivíduo facilmente obteria mediante o sistema único de saúde ou se demandam prestações que não fazem parte do sistema, inovando e criando políticas públicas) bem como será analisada a fundamentação das referidas decisões, se estão amparadas na legislação, constitucional e infraconstitucional (leis, portarias, recomendações e enunciados) ou se são simploriamente fundamentadas.

\subsubsection{Procedimentos metodológicos}

A pesquisa consistiu em cadastrar as buscas pelo número do processo padronizado pelo Conselho Nacional de Justiça (CNJ), sendo pesquisados processos que tivessem a palavrachave saúde, cabendo em segunda etapa, a separação daqueles que efetivamente interessaram a atual pesquisa no âmbito da saúde pública.

Salienta-se que as decisões selecionadas para a pesquisa levaram em consideração a data de julgamento. A unidade de análise da pesquisa quantitativa foram os processos em segunda instância e esta escolha esteve relacionada com a disponibilidade on-line de dados pesquisáveis, o que não ocorre com as decisões de primeira instância, considerando-se também o encerramento na segunda instância da possibilidade de produção de matéria fático-probatória, isto é, quando não cabe mais discussão da existência do direito pleiteado. Além disso, a pesquisa se restringiu, mesmo nesta instância, às decisões colegiadas do tribunal, optando-se por escolher acórdãos.

Para realizar as buscas por jurisprudências referentes à saúde pública no Tribunal de Justiça do Estado do Ceará (TJCE), utilizou-se a seguinte plataforma virtual disponibilizada no endereço eletrônico: <http://esaj.tjce.jus.br/cjsg/resultadoCompleta.do $>$. Para a presente pesquisa consideraram-se acórdãos do ano de 2017, pois verificou-se que referidos dados passaram a ser registrados na plataforma a partir do mês de julho de 2015, e o ano de 2016 encontra-se incompleto, com um lapso temporal sem registro, some-se a isso o fato de que em novembro de 2016 se deu a criação do Núcleo de Apoio Técnico do Poder Judiciário (NAT- 
JUS), de modo que efetivamente somente a partir do ano de 2017 é possível verificar qualquer impacto desse arranjo na quantidade ou qualidade de acórdãos e decisões monocráticas.

O levantamento dos dados realizou-se mediante a seleção dos acórdãos disponíveis no sítio eletrônico do TJCE referentes a palavra-chave: "saúde". A identificação dos acórdãos relevantes para a pesquisa deu-se pela leitura das ementas e eliminação de recursos que não diziam respeito ao objeto da pesquisa, como aqueles referentes a matéria administrativa, criminal, consumidor, previdenciário, conflito de competência, saúde suplementar (planos de saúde) e planos estatutários (IPM, ISSEC etc.) (PASSOS; GOMES, 2017).

Ainda durante a análise inicial dos referidos acórdãos, verificou-se a existência de recursos versando exclusivamente sobre questões processuais, pedidos indenizatórios, honorários advocatícios/sucumbenciais e astreintes que, por também não serem considerados relevantes para a pesquisa, foram excluídos.

O conjunto das decisões obtidas no sítio, com data do julgamento entre 01/01/2017 e 31/12/2017, utilizando-se o termo "saúde", totalizou 3308 acórdãos, sendo que desses 605, foram considerados relevantes para a pesquisa.

\subsubsection{Cálculo Amostral}

Após a triagem dos acórdãos realizada no sítio eletrônico do Tribunal de Justiça do Estado do Ceará (TJ-CE), verificou-se, em 2017, a existência da 605 acórdãos conforme as palavras-chaves relacionadas à judicialização da saúde. Dessa maneira, as unidades de observação foram os acórdãos e a definição do tamanho da amostra ou número de acórdãos que foram efetivamente pesquisados foi determinado por meio da seguinte expressão sugerida por Fávero et al. (2009):

$$
n=\frac{Z^{2} \times p \times q \times N}{e^{2}(N-1)+Z^{2} \times p \times q}
$$

Sendo: $n=$ tamanho da amostra; $Z=$ valor correspondente ao nível de significância adotado; $p=$ porcentagem ou proporção com qual o fenômeno pesquisado se verifica; $q=$ porcentagem ou proporção complementar ao fenômeno pesquisado; $N=$ tamanho da população; $e=$ erro amostral.

Calculou-se, portanto, o tamanho da amostra considerando um nível de significância de $5 \%$ e, consequentemente, $Z_{\text {calculado }}=1,96$ conforme tabela estatística. A porcentagem com o 
qual o fenômeno se verificou foi de 50\%, ou seja, $\mathrm{p}=\mathrm{q}=50 \%$. Em relação ao erro amostral, foi utilizado o máximo permitido que é de 5\%. Diante desse cálculo amostral, obteve-se uma amostra composta por 235 acórdãos que foram selecionados aleatoriamente e com representação de todos os meses do ano de 2017.

\subsubsection{Variáveis}

Procedeu-se a análise jurisprudencial no âmbito do Tribunal de Justiça do Estado do Ceará, com o objetivo de construir um perfil dos litígios em saúde pública, buscando categorizálos mediante os seguintes dados:

Utilizou-se como instrumento para coleta de dados, um formulário elaborado para este fim com as seguintes variáveis: $\mathrm{n}^{\mathrm{o}}$ do acórdão do Tribunal; data do Julgamento em $2^{\mathrm{a}}$ Instância; nome do relator; tipo de ação; legitimidade passiva; comarca de origem da ação; representação jurídica do autor; titularidade da ação; condição econômico-financeira do autor; pedido liminar; demanda requerida; resultado em $1^{\mathrm{a}}$ instância; resultado em $2^{\mathrm{a}}$ instância; deferimento da demanda de saúde na liminar/sentença e no acórdão; argumentação legal da decisão; argumentação de princípios de direito presentes na decisão.

Para a análise cada variável foi categorizada como se segue: tipo de ação (ação ordinária, mandado de segurança, ação civil pública), legitimidade passiva (Estado ou Município), a representação jurídica do autor (Defensoria Pública, Ministério Público ou advogado particular); condição econômico-financeira do autor (se foi mencionado na decisão o fato do demandante ser hipossuficiente economicamente ou ter condições econômico-financeiras), a titularidade da ação (individual, coletivo ou individual e coletivo, quando o pedido se fundamentar em apenas um demandante, mas pedir a extensão a outros com condição semelhante), deferimento ou indeferimento de pedido liminar; resultado favorável ao demandante ou o demandado.

Nos acórdãos analisados, não foi possível identificar o perfil das doenças que tem gerado uma maior busca por ações judiciais, nem a existência de elementos probatórios como laudos, devido à natureza recursal das demandas, que prescinde dessas informações. Outrossim, a fundamentação das decisões raramente possui da classificação internacional da doença (CID) para melhor identificação das patologias, motivo pelo qual existe uma variação de nomes científicos, o que impossibilitou a análise de perfil de demandas por doenças ou fármacos (PASSOS; GOMES, 2017). 
As demandas serão identificadas conforme as seguintes categorias: medicamento, alimentação, intervenção cirúrgica, exames complementares, tratamentos especializados, custeio, internação hospitalar, transporte hospitalar, outros tratamentos.

Para os argumentos legais foram determinadas as seguintes categorias: saúde e seguridade social (artigos constitucionais do art. 196 a 203); solidariedade dos entes estatais (artigo 23 da Constituição Federal); princípios fundamentais (art. $1^{\circ}$ ao $\operatorname{art} .5^{\circ}$ da Constituição Federal); direitos Sociais (art. $6^{\circ}$ ao $9^{\circ}$ da Constituição Federal); outras disposições constitucionais relativas a saúde (artigos 37, 127, 165, 167, 169, 194, 195, 226, 227, CF/88) e outras disposições relativas a saúde (Lei no 8.080/90, Lei n ${ }^{\circ}$ 9.787/99; Lei n ${ }^{\circ}$ 10.216/01; Estatuto da criança e do adolescente; Estatuto do Idoso; Estatuto da pessoa com deficiência; art.245 da Constituição do Estado do Ceará; Súmula no 45 do Tribunal de Justiça do Estado do Ceará; parecer do NAT'JUS).

Os argumentos de princípios de direito foram agrupados nas seguintes categorias: Direito à saúde, Direito à vida, Dignidade da pessoa humana; Mínimo Existencial; Integralidade; Razoabilidade; outras argumentações.

Apesar da coleta dos dados ser quantitativa, a análise dos dados abarcará um componente qualitativo.

\subsubsection{Análise}

Para a construção das tabelas a seguir foi utilizada a frequência simples ou absoluta $\left(f_{i}\right)$, referindo-se ao número de observações de um valor individual. De modo que a soma das frequências simples é igual ao número total das observações envolvidas no atual processo investigativo. Em relação à frequência relativa $\left(F_{r}\right)$ encontrada na tabela, representa a proporção de observações de um referido valor ou item em relação ao número total de observações, descrito da seguinte maneira:

$$
\mathrm{Fr}=\frac{\mathrm{fi}}{\sum \mathrm{fi}} * 100
$$

Ressalte-se que a soma das frequências relativas é igual a 1 ou a 100\%. Para uma melhor apresentação, os resultados estão dispostos em tabelas elaboradas com a ajuda do Microsoft Excel. 


\subsubsection{Questões éticas}

Tratando-se de pesquisa que envolve a análise de banco de dados públicos, disponibilizados via internet, restou dispensa a aprovação do Comitê de ética em pesquisa, no entanto, alguns princípios éticos foram observados como: a adequação aos princípios científicos, obediência à metodologia adequada e o cuidado na preservação do anonimato dos envolvidos nos processos judiciais, conforme especificado na Resolução no 196/96 (TRAVASSOS, 2012).

\subsubsection{Resultados e discussão}

Na análise dos resultados, verificou-se que, no ano de 2017, o ente da administração pública mais demandado judicialmente foi o Estado do Ceará, sendo parte requerida em 57,9\% das ações que originaram os recursos, as demandas movidas unicamente contra os Municípios somaram $34 \%$, enquanto os dois entes foram requeridos conjuntamente em $8,1 \%$ dos casos, conforme tabela abaixo.

Tabela 2 - Legitimidade das ações segundo os acórdãos demandados em 2017.

\begin{tabular}{|c|c|c|}
\hline Legitimidade Passiva & Frequência Absoluta & Frequência Relativa (\%) \\
\hline Estado & 136 & 57,9 \\
\hline Município & 80 & 34,0 \\
\hline Ambos & 19 & 8,1 \\
\hline Total & 235 & 100,0 \\
\hline
\end{tabular}

Fonte: Elaborado pelo Autor.

$\mathrm{Na}$ análise dos acórdãos, constatou-se que em algumas dessas demandas, quando a parte requerida se trata do Estado do Ceará, o mesmo chama determinado Município ao feito, alegando sua incompetência para figurar no pólo passivo da ação, contudo referido argumento normalmente não obtém sucesso.

Segundo o processo investigativo 64,3\% dos acórdãos são provenientes de ações que tramitaram na Comarca de Fortaleza (Tabela 3). As ações que se originaram na Comarca de Juazeiro do Norte somam 22\%, seguida da comarca do Crato, com 14\%, Macaranaú, $12 \%$ e assim em diante, conforme tabela abaixo. Isso demonstra que a judicialização da saúde no Estado concentrou-se na capital e em cidades específicas, com forte participação da Comarca de Juazeiro do Norte. 
Tabela 3 - Comarca de origem da ação, segundo os acórdãos demandados em 2017.

\begin{tabular}{lcc}
\hline \multicolumn{1}{c}{ Comarca de Origem } & Frequência Absoluta & Frequência Relativa (\%) \\
\hline Fortaleza & 151 & 64,3 \\
Juazeiro do Norte & 22 & 9,4 \\
Crato & 14 & 6,0 \\
Maracanaú & 12 & 5,1 \\
Caucaia & 5 & 2,1 \\
Outro município & 28 & 11,9 \\
Não informado & 3 & 1,3 \\
\hline Total & $\mathbf{2 3 5}$ & $\mathbf{1 0 0 , 0}$ \\
\hline
\end{tabular}

Fonte: Elaborado pelo Autor.

Conforme tabela a seguir, os tipos de ações mais frequentes foram as ordinárias $(87,2 \%)$ seguidas dos mandados de segurança (18\%) e ações civis públicas (8\%). Importante ressaltar que apesar da existência de ações civis públicas, foi constatado uma tendência às mesmas serem de titularidade individual, aliás, dos 235 acórdãos envolvidos na pesquisa, verificou-se que as ações que lhe são originárias têm caráter individual, o que representa 100\% dos acórdãos pesquisados. Constatando-se assim a predominância de litigância individual.

Resta demonstrado ainda na tabela abaixo que a maioria das ações que deram origem aos acórdãos pesquisados possuem como representante jurídico da parte autora a Defensoria Pública do Estado (51,9\%). Impende ressaltar que nos acórdãos em que a Defensoria Pública do Estado é mencionada, normalmente consta apelação em relação aos honorários advocatícios, que, se impetrados contra o Estado costumam ser indeferidos com base na Súmula 421 do STJ. Ao longo do ano de 2017, a Defensoria Pública do Estado do Ceará impetrou diversos recursos nesse sentido, versando tão somente sobre honorários advocatícios, em todos os casos semelhantes pesquisados houve o indeferimento do recurso.

Também é relevante a quantidade de acórdãos que não fazem referência ao representante jurídico do autor $(40,4 \%)$, caso estes acórdãos sejam provenientes da advocacia particular, o número de $42,1 \%$ de ações demonstraria sua expressiva participação na judicialização da saúde pública. 
Tabela 4 - Tipo de ação, representante jurídico do autor e titularidade segundo os acórdãos demandados em 2017.

\begin{tabular}{lcc}
\hline \multicolumn{1}{c}{ Características da Ação } & Frequência Absoluta & Frequência Relativa (\%) \\
\hline Tipo de Ação & 205 & \\
Ação Ordinária & 18 & 87,2 \\
Mandado de Segurança & 8 & 7,7 \\
Ação Civil Pública & 4 & 3,4 \\
Não informado & & 1,7 \\
Representante Jurídico do Autor & 122 & \\
Defensoria Pública & 3 & 51,9 \\
Advogado Particular & 15 & 1,3 \\
Ministério Público & 95 & 6,4 \\
Não informado & & 40,4 \\
Titularidade das Açães & 235 & 100,0 \\
Individual & 0 & 0 \\
Coletiva & 0 & 0 \\
Individual e Coletiva & & \\
\hline
\end{tabular}

Fonte: Elaborado pelo Autor.

Na tabela abaixo, consta que em $76,6 \%$ das decisões é mencionado o fato do demandante ser hipossuficiente economicamente, sendo que em nenhuma das decisões pesquisadas faz-se referência ao fato do autor possuir condições financeiras suficientes para arcar com a demanda de saúde pretendida. Em algumas decisões não foram informadas as condições financeiras do autor, 23,4\%, mas nesses casos também podem se tratar de demandantes hipossuficientes, apenas os acórdãos não lhes fazem referência.

Tabela 5 - Condição econômico-financeira do autor da ação segundo os acórdãos demandados em 2017.

\begin{tabular}{lcc}
\hline \multicolumn{1}{c}{ Condição Econômico-Financeira do Autor } & Frequência Absoluta & Frequência Relativa (\%) \\
\hline Mencionado na decisão o fato do demandante ser & 180 & 76,6 \\
hipossuficiente economicamente & 0 & 0,0 \\
Demandante com condições econômico-financeiras & 55 & 23,4 \\
Não informado & $\mathbf{2 3 5}$ & $\mathbf{1 0 0 , 0}$ \\
\hline Total &
\end{tabular}

Fonte: Elaborado pelo Autor

* A menção à palavra hipossuficiência, sem se referir ao autor da ação não foi contabilizada. 
Do total de acórdãos pesquisados, em primeira instância, constatou-se que $83,0 \%$ das decisões foram favoráveis aos usuários, enquanto apenas $7,2 \%$ foram favoráveis a administração pública, sendo que 6,0\% das decisões favoreceram ambas as partes. Já em segunda instância o número de decisões favoráveis aos usuários, aumenta para 93,6\%, demonstrando que em primeira instância há uma maior probabilidade de a demanda ser negada ao usuário.

Cumpre ressaltar que grande maioria dos casos em que os resultados foram favoráveis igualmente aos usuários e ao SUS, se deu por deferimento da demanda de saúde e indeferimento da indenização em danos morais pleiteada pela parte autora. Ressaltando-se que apresente pesquisa não levou em consideração a condenação em honorários advocatícios para se considerar se a demanda foi ou não favorável ao usuário ou ao SUS.

Tabela 6 - Resultados das ações em primeira e segunda instância segundo os acórdãos demandados em 2017.

\begin{tabular}{lcc}
\hline & Frequência Absoluta & Frequência Relativa (\%) \\
\hline Resultado (Liminar/Sentença) em Primeira Instância & & \\
Favorável ao Usuário & 195 & 83,0 \\
Favorável ao SUS & 17 & 7,2 \\
Favorável ao Usuário e ao SUS & 14 & 6,0 \\
Não se aplica* & 9 & 3,8 \\
Resultado em Segunda Instância & & \\
Favorável ao Usuário & 220 & 93,6 \\
Favorável ao SUS & 3 & 1,3 \\
Favorável ao Usuário e ao SUS** & 12 & 5,1 \\
\hline
\end{tabular}

Fonte: Elaborado pelo Autor.

"Relativo a ações que tramitaram exclusivamente em $2^{\mathrm{a}}$ instância ou não sentenciadas em $1^{\mathrm{a}}$ instância.

** Caso em que a demanda de saúde foi deferida, mas o pedido de reparação de danos morais foi julgado improcedente, por exemplo.

Quanto ao deferimento da demanda de saúde na sentença e no acórdão, verifica-se da tabela abaixo que em 88,5\% dos casos há confirmação do deferimento da demanda de saúde solicitada na ação originária também no acórdão, demonstrando o nível de consonância dos entendimentos em primeira e segunda instância, ressaltando que estão excluídos dessa análise a apreciação judicial de danos morais e honorários advocatícios.

Quanto aos pedidos liminares, independentemente da instância demanda, constatase que apresenta uma frequência relevante de deferimento em $88,9 \%$ dos casos demandados. 
Tabela 7 - Deferimento do pedido na sentença e no acórdão segundo as ações demandadas em 2017.

\begin{tabular}{|c|c|c|c|}
\hline & & Frequência Absoluta & Frequência Relativa (\%) \\
\hline $\begin{array}{l}\text { Deferimento da demanda } \\
\text { liminar/sentença e no acórdão* }\end{array}$ & $n a$ & & \\
\hline Deferido nas duas instâncias & & 208 & 88,5 \\
\hline Negado em pelo menos uma das instâncias & & 18 & 7,7 \\
\hline Negado nas duas instâncias & & 0 & 0,0 \\
\hline Não se aplica** & & 9 & 3,8 \\
\hline \multicolumn{4}{|l|}{ Pedido de Liminar } \\
\hline Deferida & & 209 & 88,9 \\
\hline Indeferida & & 7 & 3,0 \\
\hline Não informado & & 19 & 8,1 \\
\hline
\end{tabular}

Fonte: Elaborado pelo Autor.

"Refere-se apenas a demanda em saúde, sem considerar pedido de reparação cível, por exemplo.

${ }^{* *}$ Refere-se aos casos em que o processo tenha tramitado em apenas uma instância, por exemplo.

$\mathrm{Na}$ análise dos acórdãos, constatou-se ainda que em grande parte das ações, a demanda requerida foi por medicamentos $(30,6 \%)$, internação hospitalar $(23,8 \%)$, seguidos de alimentação específica $(19,6 \%)$ e insumos $(18,3 \%)$. Verifica-se a expressiva demanda por leitos de UTI no Estado, só se afigurando menor do que a demanda por medicamentos. Cumpre ressaltar, quanto aos medicamentos solicitados, que nas decisões analisadas, seu deferimento por parte do Tribunal não restou condicionado a pertencer as listas oficias do SUS.

Dentre as demandas apresentadas, constaram em Custeio: energia elétrica para aparelho de ventilação mecânica, Alimentação: Alimentação especial e enteral, Insumo: fraldas geriátricas, Equipamento hospitalar: cadeira de rodas, bomba de insulina, cama hospitalar e em Outros tratamentos: internação para tratamento de dependência química. Algumas dessas demandas como a relativa a fraldas geriátricas, ao serem levadas ao crivo do Poder Judiciário, até mesmo perante segunda instância, demonstra o quanto a judicialização da saúde é dispendiosa para o Estado, sobretudo por sobrecarregar seus magistrados com demandas que poderiam ser resolvidas na via administrativa.

Tabela 8 - Distribuição das demandas requeridas segundo os acórdãos demandados em 2017.

\begin{tabular}{lcc}
\hline \multicolumn{1}{c}{ Demanda Requerida na Ação* } & Frequência Absoluta & Frequência Relativa (\%) \\
\hline Medicamento & 72 & 30,6 \\
Alimentação & 46 & 19,6 \\
Intervenção cirúrgica & 21 & 8,9 \\
Exames complementares & 7 & 3,0 \\
Tratamentos especializados & 7 & 3,0
\end{tabular}




$\begin{array}{lcc}\text { Custeio } & 2 & 0,9 \\ \text { Insumos } & 43 & 18,3 \\ \text { Internação hospitalar } & 56 & 23,8 \\ \text { Transporte Hospitalar } & 1 & 0,4 \\ \text { Equipamento Hospitalar } & 6 & 2,6 \\ \text { Outros tratamentos } & 10 & 4,3\end{array}$

Fonte: Elaborado pelo Autor.

*Houve acórdãos com mais de uma demanda requerida.

A argumentação baseada em princípios mais frequente nas decisões judiciais foi o direito à saúde $(98,7 \%)$, seguido do direito à vida $(94,9 \%)$ e da dignidade da pessoa humana $(82,1 \%)$. As teorias do mínimo existencial, da reserva do possível e princípio da isonomia apesar de apareceram em inúmeros acórdãos não foram contabilizados pois praticamente não foram utilizadas como argumento para deferir ou indeferir pedidos, apenas se fez referência aos mesmos para afirmar de forma breve que a decisão de deferimento não consiste em violação aos mesmos. O princípio do mínimo existencial aparece em 50,2\% dos acórdãos e o da razoabilidade em $20,9 \%$.

Quanto ao princípio da integralidade, que aparece em 11,1\% dos acórdãos, não foi utilizado para conceder "todo e qualquer pedido", apenas fez-se rápida referência ao princípio nos termos da Lei $n^{\circ}$ 8.080/90. Impende ressaltar que foi feita a contabilização dos argumentos de princípio que de alguma forma contribuíram para a decisão e não foram contabilizados os princípios fundados em dispositivos constitucionais ou legais já referidos nas decisões e contabilizados na tabela seguinte, a fim de evitar que constassem em duplicidade no estudo.

Tabela 9 - Argumentações de princípios de direito nas decisões judiciais segundo os acórdãos demandados em 2017.

\begin{tabular}{lcc}
\hline \multicolumn{1}{c}{ Princípios de Direito } & Frequência Absoluta & Frequência Relativa (\%) \\
\hline Direito à Vida & 223 & 94,9 \\
Direito à Saúde & 232 & 98,7 \\
Dignidade da pessoa humana & 193 & 82,1 \\
Mínimo Existencial & 118 & 50,2 \\
Integralidade & 26 & 11,1 \\
Razoabilidade & 49 & 20,9 \\
Outras Argumentações** & 66 & 28,1 \\
\hline
\end{tabular}

Fonte: Elaborado pelo Autor.

* Houve acórdãos com mais de uma argumentação legal.

** Princípios da proporcionalidade, universalidade, causalidade, legalidade, economicidade, interesses individuais indisponíveis, subsidiariedade, máxima efetividade dos direitos fundamentais, outros. 
Da análise do conteúdo legal observou-se que o argumento mais frequentemente utilizado para fundamentar as decisões foi a Constituição Federal, em seus artigos 196 a 203. Raríssimas decisões no universo estudado citam ou tomam como referência os enunciados do CNJ ou mencionam parecer proveniente do NATJUS-CE. Em muitas delas se fez constar, contudo, a Súmula nº 45 do TJCE.

Tabela 10 - Argumentações legais nas decisões judiciais segundo os acórdãos demandados em 2017.

\begin{tabular}{|c|c|c|}
\hline Argumentação Legal da Decisão* & Frequência Absoluta & Frequência Relativa (\%) \\
\hline Saúde e seguridade social (art.196 a 203, CF/88) & 216 & 91,9 \\
\hline Solidariedade dos entes estatais (art.23, CF/88) & 150 & 63,8 \\
\hline $\begin{array}{l}\text { Outras disposições constitucionais relativas a saúde } \\
\text { (artigos 37,127,165,167,169,194,195,226,227, CF/88) }\end{array}$ & 42 & 17,9 \\
\hline Princípios fundamentais (art. $1^{\circ} \mathrm{e}$ art. $5^{\circ}, \mathrm{CF} / 88$ ) & 177 & 75,3 \\
\hline Direitos Sociais (art. $6^{\circ}$ ao $9^{\circ}, \mathrm{CF} / 88$ ) & 184 & 78,3 \\
\hline
\end{tabular}

Outras disposições referentes a saúde: Lei nº 8.080/90, Lei no 9.787/99; Lei no 10.216/01; Estatuto da criança e do adolescente; Estatuto do Idoso; Estatuto da pessoa com deficiência; art.245 da Constituição do Estado do

Ceará; Súmula $\mathrm{n}^{\circ} 45$ do Tribunal de Justiça do Estado do Ceará; parecer do NAT'JUS.

Nenhuma Argumentação

14

6,0

Fonte: Elaborado pelo Autor.

*Houve acórdãos com mais de uma argumentação legal.

Os achados da pesquisa apontaram no mesmo sentido das orientações do STF, as decisões foram deferidas considerando o direito a saúde como um direito fundamental subjetivo, que deve ser assegurado em sua integralidade pelo Judiciário, diante da omissão do poder público.

Ressalte-se que houve prevalência de ações de natureza individual e alta frequência de decisões em primeiro e segundo graus favoráveis aos usuários, fazendo com que a probabilidade de a demanda ser deferida se aproxime de $90 \%$ dos casos.

Atualmente há uma preocupação muito grande com a judicialização da saúde no que diz respeito ao extraordinário, àquilo que não está na política pública de saúde, a melhor órtese, prótese, medicamento especial existente no cenário mundial, com a intervenção tecnológica, 
com os novos produtos, mas há uma baixa atenção no que diz respeito à atenção básica de saúde.

A análise da jurisprudência do Tribunal de Justiça do Estado do Ceará, no ano de 2017, contudo, revela que a litigiosidade é formada fundamentalmente por demandas em saúde que já encontram esteio para seu fornecimento pelas vias de acesso normais ao Sistema Único de Saúde, sem apresentar a necessidade excepcional de intervenção judicial na Política Pública de Saúde. Essa forma de judicialização pode ser reduzida através da criação de mecanismos que fomentem a chamada desjudicialização, solucionando as demandas individuais na esfera extrajudicial, com redução das desigualdades sociais e tratando de forma adequada o cidadão na perspectiva da concretização do direito à saúde, conforme o disposto infra e constitucionalmente.

Uma política de autocontenção também pode contribuir para o fortalecimento da política pública. Não obstante a existência de mecanismos para que possa ser atingida, conforme visto ao longo do item 4.4, os dados relacionados a fundamentação das decisões demonstraram uma tímida menção a Enunciados do CNJ ou pareceres do NAT'JUS.

O próximo tópico pretende analisar a teoria dos diálogos institucionais e sua contribuição como estratégia de mitigação da excessiva judicialização das demandas em saúde no contexto nacional e estadual.

\subsection{Desjudicialização da saúde: o Diálogo Institucional como ferramenta de acesso à Justiça}

O tema de diálogo institucional se tornou uma valiosa ferramenta no tratamento da judicialização excessiva da política pública de saúde. Macedo (2016, p.166-167) explica que a teoria do diálogo institucional, surgiu em 1997 no Canadá em decorrência da adoção no direito consuetudinário canadense da Carta Canadense de Direitos e liberdades (Canadian Charter of Rights and Freedoms) de 1982, que configurou autêntico texto constitucional. Para enfrentar os conflitos entre os poderes do Estado, e em especial as dificuldades de legitimidade entre o poder legislativo e o judiciário surgiu a denominada teoria da "Charter Dialogue" (diálogo institucional) que identificou no diálogo entre o judiciário e o legislativo a construção de leis que realizassem de maneira mais eficaz as garantias da $\operatorname{Carta}^{82}$.

\footnotetext{
${ }^{82}$ Souza explica que através dessa carta, atribuiu-se às Cortes importantes poderes de garantir de direitos individuais e de grupos minoritários, através da invalidação de leis incompatíveis com a mesma, mas, no entanto, ao parlamento foram garantidas poderosas atribuições, quer seja para impor limites justificados aos mencionados
} 
Atualmente existe uma pluralidade de teorias dialogais e apesar de haver uma certa correlação entre os modelos dialógicos, como o Canadense e as teorias do diálogo, não há entre elas qualquer relação de necessidade ou suficiência, como é o caso dos EUA, que apesar de ser um modelo de Supremacia Judicial, pode se converter ao diálogo na medida em que os juízes passem a exercer controle fraco, demonstrando deferência para com os atos dos órgãos majoritários (SOUZA, 2011).

Apesar de sistema brasileiro não apresentar um mecanismo institucionalizado para que no limiar do desacordo o Parlamento ou o Executivo respondam, em um espaço de tempo curto, às decisões do STF, pode-se perceber os esforços no sentido de minimizar os efeitos antidemocráticos dessas características: "por meio da abertura procedimental do próprio processo judicial de controle de constitucionalidade à participação de outros atores da sociedade civil, como nos casos das audiências públicas ou do amicus curiae". No Brasil possuiríamos um modelo moderadamente dialógico, e que especificamente no campo da saúde, quanto mais interação houver maiores as chances de se obter as melhores respostas (SOUZA, 2011, p. 77).

Em apertada síntese, a metáfora dos diálogos institucionais busca disseminar a ideia de que, para a realização dos pressupostos do Estado Democrático de Direito, o sentido futuro da Constituição não pode ser encarado como uma prerrogativa "suprema" de nenhum dos poderes. Por meio desse modelo decisório, cético quanto às capacidades institucionais dos órgãos estatais, "[...] busca-se conter a tirania da minoria com eleições regulares, e a tirania da maioria com vários instrumentos de freios e contrapesos: veto presidencial, legislativo bicameral, federalismo e controle de constitucionalidade" (BRANDÃO, 2012, p. 288).

Em substituição a tradicional leitura da separação dos poderes, a prática dos diálogos institucionais busca evidenciar pelo menos dois aspectos a respeito da formulação de decisões de casos controvertidos: inicialmente, as decisões, tomadas em qualquer um dos poderes, passam a ser dotadas de um caráter parcialmente definitivo, podendo ser contestadas em outras instâncias públicas. Em segundo lugar, cada espaço de poder possui características que o potencializam ou o inibem para a realização de tomada de decisões:

Isso reafirma a necessidade de canais de diálogo entre as instituições, pois, uma pode ter melhores condições que outra para lidar com o caso concreto em apreço. Destarte, do mesmo modo que o Legislativo costuma adotar um discurso político para a formação de consenso, o Judiciário precisa traduzir demandas políticas em termos jurídicos. Tais diferenças irão complementar o conjunto de discursos produzidos sobre

direitos, que seja para superá-los por um período limitado de tempo. (SOUZA, Jorge Munhós de. Diálogo institucional e direito à saúde. Dissertação apresentada como requisito parcial à obtenção do título de Mestre em Direito na Universidade do Estado do Rio de Janeiro, RJ, 2011, p.46. Disponível em: <https://oatd.org/oatd/record?record=oail\%3Awww.bdtd.uerj.brl\%3A1929>. Acesso em: 10 jan 2018. 
o tema até o momento e conferir novas rodadas deliberativas sobre a matéria (CLÉVE; LORENZETTO, 2015, p.1).

A teoria dos diálogos institucionais surge com o objetivo de minimizar os impactos da supremacia judicial, do autoritarismo judicial, que nas demandas relacionadas a saúde podem não solucionar o problema, mas agravar a situação da ineficiência da saúde pública.

O interessante é perceber que a disseminação da metáfora do diálogo traz para o bojo
da discussão uma imagem fecunda na política que conclama a igualdade, à
horizontalidade e ao respeito mútuo aos agentes envolvidos na tomada de decisões
coletivas, abrindo, desta forma, possibilidades de que a separação dos poderes seja
entendida, para além de sua função clássica de contenção recíproca, como instrumento
de cooperação entre instituições que dialogam entre si na busca de melhores respostas
que compatibilizem os direitos individuais com as finalidades coletivas perseguidas
pela maioria (por meio de políticas públicas) (SOUZA, 2011, p. 39).

Como alternativa para que as instituições judiciais possam intervir no controle externo de políticas públicas, colaborando para sua formulação, propõe-se a realização de diálogos com os demais centros de decisão, "especialmente daqueles que criam e efetivam essas políticas", sendo desaconselhado o isolamento de quem realiza esse controle externo em relação aos legitimados para prever e executar políticas públicas e vice-versa (MARIANO et al., 2018, p. 176).

A teoria dos diálogos institucionais serve para auxiliar a apresentação de respostas as seguintes questões como: quem possui a última palavra sobre o conteúdo do direito à saúde? $\mathrm{O}$ executivo, quando cria e executa a política? O legislativo, quando edita leis? Ou o judiciário, quando julga processos judiciais? (SCHULZE; GEBRAN NETO, 2016).

A interpretação constitucional comparada a um diálogo, pode ser traduzida da seguinte forma:

Embora seja muito útil saber como não se deve ler a Constituição, no final das contas, juízes, legisladores e aqueles que ocupam cargos do Poder Executivo, encarregados de interpretar a Constituição, precisam ser capazes de lê-la. Ler a Constituição não requer uma teoria de interpretação que englobe a Constituição inteira. Dessa forma, poderíamos cair na hiper-integração. Ao mesmo tempo em que nos esforçamos para evitar os monstros marinhos da Scila da hiper-integração, temos que fugir dos monstros do Caridbes da des-integração ${ }^{83}$. Embora seja impossível oferecer uma teoria da interpretação constitucional totalmente consistente, podemos ao menos ensaiar algumas abordagens aceitáveis para tal empreendimento. $\mathrm{O}$ objetivo que nos colocamos parece demasiadamente hesitante e tentativo, e isso se deve ao fato de as questões dirigidas para a interpretação constitucional serem ao mesmo tempo extremamente básicas e difíceis. Na maior parte das vezes, não temos respostas, e aquelas que conseguimos dar quase nunca são precisas. Não é possível alcançar a definição da última palavra da essência da Constituição; quando isso se torna possível, a Constituição acaba de perder sua relevância perante uma sociedade em constante mudança. Com menos ambição e talvez com o pé mais fincado na realidade,

\footnotetext{
${ }^{83}$ Scila e Caridbes consistem em dois monstros marinhos para a mitologia grega.
} 
pretendemos contribuir com um diálogo útil para a leitura da Constituição, uma 'conversa constitucional' (TRIBE; DORF, 2007, p.35).

Essa noção é decorrente do Constitucionalismo cooperativo, que exige a contínua e permanente aproximação entre os agentes públicos e os tribunais com a sociedade, para além disso, o diálogo existe também para permitir a independência e autonomia entre os Poderes da União, nos termos preconizados pelo artigo $2^{\circ}$ da Constituição:

Dessa forma, a abertura da interpretação constitucional e da pluralização dos rol dos agentes autorizados a participar dos conflitos de interesses não se limita apenas aos cidadãos, tal como propõe a Teoria de Häberle ${ }^{84}$, permitindo-se também a integração dos demais órgãos, entes e Poderes do Estado, com o fim de conferir maior eficácia às normas estampadas no texto da Constituição (SCHULZE; GEBRAN NETO, 2016, p. 73).

A teoria do diálogo aplicada ao direito à saúde considera importante a função que o Judiciário possui na sua proteção e promoção, contudo, tenta desmistificar o papel da judicialização no processo de proteção dos direitos sociais, reconstruindo as bases teóricas para a intervenção nesses assuntos sob premissas menos pretenciosas (SOUZA, 2011). Listando as vantagens da teoria dos diálogos institucionais, (SCHULZE; GEBRAN NETO, 2016, p.74) destaca:
1) fortalecimento das instituições;
2) comprometimento dos atores a participar dos debates;
3) decisão debatida dialogicamente tem efeitos mais duradouros;
4) prestigia a maioria - amplia o número de pessoas beneficiadas pela decisão;
5) evita imposição unilateral (autoritarismo judicial).

Para Brandão (2012, p. 289) um modelo dialógico:

[...] (i) provê múltiplos pontos de acesso aos interessados em determinada questão constitucional, na medida em que eles podem atuar perante instituições diversamente representativas (sobretudo o Judiciário e o Legislativo), o que promove o pluralismo e a democracia; (ii) reduz a oportunidade de atuação unilateral de quaisquer "poderes", intensificando os mecanismos de freios e contrapesos, fator que tende a conter o exercício arbitrário do poder estatal.

$\mathrm{Na}$ área da saúde, ressalte-se a iniciativa do Conselho Nacional de Justiça que através de Comitê Organizador do Fórum Nacional do Judiciário realizou a I e II Jornadas de Direito à Saúde, respectivamente em 2014 e 2015, proporcionando um diálogo entre membros do Ministério Público, Defensoria Pública, Juízes das Varas de Fazenda Pública e Cíveis, Advogados, Gestores do SUS, Assessorias Jurídicas das Secretarias de Saúde, membros dos

\footnotetext{
${ }^{84} \mathrm{HÄBERLE}$, Peter. Hermenêutica Constitucional. A sociedade aberta dos intérpretes da Constituição: Contribuição para a interpretação pluralista e procedimental da Constituição. Tradução de Gilmar Ferreira Mendes. Porto Alegre: Sergio Antonio Fabris Editor, 2002. Título original: Die OffeneGesellschaft der Ver fassungs interpreter. EinBreitragzurpluralistischenund 'prozessualen'.
} 
COSEMS - Conselho das Secretarias Municipais de Saúde, representantes dos Conselhos Municipais de Saúde, entre outros, tornando o ambiente de discussão não apenas extremamente rico por sua interdisciplinariedade, intersetorialidade e interregionalidade, bem como pelo alto nível de qualificação técnica dos discursos ali apresentando (MACEDO, 2015, p. 233):

Todos esses diálogos em diversos sotaques do Brasil discutindo uníssonos por propostas para uma melhor judicialização fazem deste Fórum um exemplo vivo do diálogo institucional, do diálogo social, ou mesmo de um chamado "diálogo interinstitucional".

Não raramente é possível localizar a ideia de diálogo institucional nas discussões, por exemplo, do Fórum Nacional de Saúde Pública, que ocorre no âmbito do CNJ, como um dos remédios para a crise não apenas de acesso, mas de efetivação do direito fundamental social à saúde (MACEDO, 2016).

O relatório Judicialização da saúde no Brasil, elaborado pelo Conselho Nacional de Justiça (CNJ, 2014), que analisa o cenário da judicialização da saúde e a política judiciária de saúde no Brasil, ressalta estratégias oriundas da política judiciária para a saúde desenvolvida pelo conselho nos últimos anos, que envolvem a criação do Fórum Nacional do Judiciário para a Saúde, de Comitês Estaduais de Saúde e de recomendações sobre como os juízes podem decidir as demandas que lhes são apresentadas.

Observada a teoria dos diálogos institucionais, o CNJ tem fomentado o encontro entre os diversos setores públicos e privados para debater a saúde e sua judicialização, essas estratégias demonstram a importância que o referido conselho atribui à interrelação do Judiciário e as demais instituições políticas e participativas. Ressalte-se que o próprio CNJ (2014, p. 131) reconhece como um de seus desafios institucionais intensificar o espaço de diálogo institucional:

[...] no cotidiano de suas ações, as instituições jurídicas têm a atribuição de atuar na efetivação do direito à saúde, responsabilizando e dialogando com os diversos atores sociais envolvidos em sua concretização. Em algumas experiências brasileiras, observa-se que tais instituições têm a capacidade institucional de criar um espaço de diálogo, pois possibilitam a comunicação entre os principais atores que compõem o processo de formulação, gestão e fiscalização das políticas públicas em saúde em um foro comum. Isso permite pensar a ideia de juridicização das relações sociais (conflitos são discutidos sob o ponto de vista jurídico), sem ocorrer necessariamente uma judicialização (ao máximo, se evita levar os conflitos ao Judiciário). Em virtude dessa atuação, observa-se uma valorização do diálogo, de modo a gerar ações efetivas no encaminhamento e resolução dos conflitos. Além disso, contribui decisivamente para a constituição de uma política judiciária de saúde. Por meio do diálogo, procura-se resolver alguma deficiência no sistema de saúde por intermédio de meios não formais e que, por vezes, se apresentam como o caminho mais adequado, de modo a estabelecer mecanismos de responsabilização dos membros da gestão e de incorporação de conteúdos participativo-societários nos consensos estabelecidos. $\mathrm{O}$ recurso à oralidade permite que os diferentes atores sociais extrapolem a letra da lei para que, no interior de suas práticas cotidianas, estabeleçam consensos e 
negociações. Esse espaço de diálogo preconiza que formas de resolução de conflitos devam envolver uma atuação conjunta e integrada, de modo a estabelecer mecanismos permanentes e transparentes de diálogo institucional. (grifos do original)

Macedo (2015) pontua os núcleos de assessoria técnica e os comitês interinstitucionais como materialização dos diálogos institucionais na mitigação da judicialização da saúde. Para além dos NAT's existem comitês ${ }^{85}$ que visam promover um diálogo entre instituições antes mesmo da demanda ser instalada. Referida autora, menciona o exemplo do CIRADS - Comitê Interinstitucional de Resolução Administrativa de Demandas em Saúde do Rio Grande do Norte, fundado em 22 de julho de 2009, que estabelece uma cooperação técnica entre a Procuradoria da União e do Estado, a Defensoria Pública da União, a Procuradoria Geral do Estado, a Procuradoria Geral de Natal, a Secretaria de Estado da Saúde Pública e a Secretaria Municipal de Saúde Natal e em 2010, aditou o termo para inclusão da Defensoria Pública do Estado. Ressalta a busca, através do diálogo entre essas instituições envolvidas, pela diminuição da quantidade de demandas com potencial de se tornar uma judicialização, e mesmo das que já se materializaram através da via administrativa. Havendo a possibilidade de atuação frente as autoridades na busca da melhoria das políticas realizadas para o aprimoramento do SUS, que serão sugeridas em propostas do Conselho, legitimadas por suas experiências junto à população.

Medidas como as Jornadas da Saúde, Comitês Estaduais de Saúde, Nat's ou mesmo arranjos entre instituições para resolução dos conflitos extrajudicialmente, possibilitam a essas instituições estarem envolvidas no debate da judicialização da saúde, discutindo alternativas a judicialização ou possibilitando uma judicialização mais racional e mais consonante e integrada

\footnotetext{
${ }^{85}$ No estado de São Paulo, em Ribeirão Preto, houve a criação da Comissão de Análise de Solicitações Especiais, com a atribuição de emitir parecer nos pedidos de ações judiciais enviadas pelo Ministério Público Estadual, fornecendo subsídios para as decisões. No Mato Grosso do Sul houve o estabelecimento de um Câmara Técnica em Saúde, fundado em forma de convênio com a Secretaria de Saúde do Estado e pautado nas diretrizes do Conselho Nacional de Justiça, visando também subsidiar a justiça estadual com informações técnicas nas demandas relativas ao fornecimento de medicamentos, exames, internações, e tratamentos clínicos e/ou cirúrgicos em face do Sistema Único de Saúde -SUS. Em 25 de dezembro de 2014 foi constituído o recentíssimo Comitê Interinstitucional de Resolução de Demandas em Saúde -CIRDS de Uberlândia. Este Comitê por sua vez se apresenta com dinâmica diferenciada daquela dos NAT's, se colocando numa fase anterior. Composto por representantes especialistas em Farmácia do Município de Uberlândia, do Estado de Minas Gerais e da União nomeados pelos respectivos entes federados e com eventual auxílio técnico e logístico de médicos e enfermeiros qualificados integrantes da rede pública de saúdem, possui como atribuição, conforme lermos no Capítulo II -Da Atribuição de seu Regimento Interno o seguinte: 'Art. $3^{\circ}$ É atribuição do CIRDS manifestar-se previamente, ou seja, antes da fase judicial, sobre os pedidos referentes ao fornecimento de medicamentos, tendo por objetivo a resolução extrajudicial nos termos das diretrizes do Sistema Único de Saúde, das demandas relacionadas a medicamentos.' (In MACEDO, Maiara Batalini. A judicialização da saúde pública e o diálogo institucional como garantia de equidade social. In SILVA, Juvêncio Borges; THIBAU; Tereza Cristina Sorice Baracho; MACHADO; Ednilson Donisete (Coord.). Acesso à Justiça I. Florianópolis: CONPEDI, 2015, p.249. Disponível em: $<$ https://www.conpedi.org.br/publicacoes/66fsl345/4qiqydiv/ODP1RYOOq7KmFuzR.pdf>. Acesso em 05 jan 2019).
} 
com a Política de Saúde do SUS, permitindo um fortalecimento do SUS. Conforme ressalta Mariano et al. (2018, p. 185):

Pensar o Sistema Único de Saúde (SUS) sob uma perspectiva de diálogo entre agentes da promoção da Justiça e agentes de promoção da saúde (gestores públicos, sobretudo do Poder Executivo, e profissionais da párea de saúde), incluindo na participação do diálogo a sociedade civil, faz com que o SUS dê certo, uma vez que as soluções alcançadas nesse modelo de construção nos permitem concluir que a forma como o sistema foi idealizado é viável, diante do seu fortalecimento para esta e para as futuras gerações de usuários do sistema.

À luz da teoria dos diálogos institucionais a existência dessas iniciativas permite uma ação paritária, envolvendo atores do sistema de saúde e atores do sistema de justiça. Impende destacar que a interação entre os sistemas vem sendo apreciada por diversos órgãos que lidam - quer com a oferta, quer com a garantia, quer com o controle da efetivação dos direitos sociais. No que se refere a estratégia da Mediação Sanitária, a mesma foi reconhecida pelo Tribunal de Contas da União, unanimemente em seu Plenário, como uma boa prática, conforme expresso no Acórdão TC n. 018.739/2012-1 de 24/11/2013 (CONASS, 2015) ${ }^{86}$.

\footnotetext{
${ }^{86} \mathrm{O}$ Tribunal de Contas da União (TCU) foi um dos primeiros órgãos públicos no reconhecimento da estratégia da Mediação Sanitária do MPMG como "Boas Práticas Identificadas". Essa decisão, unanimidade, pelo Plenário do TCU, se encontra no Acórdão TC 018.739/2012-1, 27/11/2013. Destaca-se, como Principais resultados da Mediação Sanitária em Minas Gerais, os seguintes: “a) elaboração de Diagnósticos Situacionais de Microrregiões de saúde pelas Comissões de Trabalho de mediação Sanitária; b) busca pelo planejamento regional da saúde, por meio de verdadeiros Contratos Organizativos de Ação Pública (COAP), temáticos; c) proposta de criação de Plano de Ação para Expansão e Melhoramentos dos serviços de saúde em face das Redes de Atenção à Saúde (RAS); d) estabelecimentos de Convênios de Cooperação Técnica Entre Entes Públicos, conforme artigo 241 da Constituição Federal; e) corresponsabilidades financeiras; f) melhoria das condições de trabalho nas unidades de saúde; g) crescimento vegetativo da assistência pautada pelo critério da epidemiologia; h) eliminação da concorrência entre os prestadores (hospitais), com definição da vocação sanitária de cada deles, a partir dos vazios assistenciais e das necessidades coletivas de saúde; i) fusão operacional da assistência de prestadores (hospitais) na mesma base territorial para os fins de racionalização e adequação à escala; j) intervenção administrativa ou judicial, conforme o caso, nas administrações hospitalares com grave comprometimento assistencial, gestão desqualificada e desequilíbrio econômico-financeiro; k) instituição do Prohosp Gestão Compartilhada pela SES/MG; 1) criação de um Grupo de Estudos para propostas de implantação de cargos e carreiras dos profissionais da ESF, no âmbito microrregional, com piso estadual, administrado por consórcio público, para os fins de sua interiorização, superação à vedação do subsídio maior no âmbito municipal e da rigidez da Lei de Responsabilidade Fiscal (limite prudencial); m) aumento do número de leitos especializados (UTI) na região de saúde; $n$ ) atualização dos estatutos e regimentos dos prestadores hospitalares conveniados ao SUS; o) ampliação da Mediação junto ao Tribunal Regional do Trabalho em Minas Gerais, nos casos de insolvência das unidades hospitalares, filantrópicas ou sem fins lucrativos, conveniadas ao SUS, nos casos de penhora de seus bens e rendas, por meio da reunificação dos processos executivos e da criação de um fundo garantidor; $p$ ) otimização dos Comitês Gestores das Redes de Urgência e Emergência; q) criação do Núcleo de Atendimentos das demandas judiciais pela SES/MG; r) revisão dos contratos de prestação de serviços médicos hospitalares, dada a Política Nacional de Atenção Hospitalar, com fomento à proposta da orçamentação global 100\% SUS, assegurado equilíbrio econômico financeiro; s) aumento da capacitação técnica sanitária pelos diversos Órgãos de Execução do Ministério Público; t) curso de especialização de direito sanitário pela Escola de Saúde Pública de Minas Gerais, com participação plural de membros do Ministério Público, Poder Judiciário e Defensoria Pública; u) redução dos confrontos, conflitos e de demandas judiciais reflexivas" (In ASSIS, Gilmar de. Mediação Sanitária: Direito, Saúde e Cidadania. Para entender a gestão do SUS. $1^{\mathrm{a}}$ edição, Brasília: CONASS, 2015, p.01-08, Disponível em: $<$ http://www.conass.org.br/biblioteca/pdf/colecao2015/CONASS-DIREITO_A_SAUDE-ART_14B.pdf> Acesso em 10 jan 2018)
} 
Antes de adentrar ao tema de Mediação Sanitária como estratégia de interação que proporciona a efetivação do direito à saúde, cumpre tecer algumas considerações a respeito do movimento pela desjudicialização. Para Oliveira (2015, p. 57) a desjudicialização consiste num movimento, cuja expressão, em sentido lato, se relaciona a todo um contexto de vias alternativas de solução de controvérsias, no sentido estrito, significa "[...] sair do Judiciário, retirando, portanto, da sua apreciação temas que antes eram de sua competência exclusiva, transferindo o processamento a outros atores" 87 .

A desjudicialização, que não é um movimento exclusivamente brasileiro ${ }^{88}$, pode ser verificado no campo do Processo Civil através de fases de um procedimento ou mesmo procedimentos inteiros que através da legislação são passados a instância extrajudicial, sendo observados ainda movimentos extrajudiciais específicos da tutela coletiva ${ }^{89}$, bem como etapas inteiras de um processo judicial, como a hipótese de desjudicialização da execução (OLIVEIRA, 2015).

No que tange a judicialização de questões sociais e políticas, um dos grandes desafios do Poder Judiciário tem sido conferir eficácia aos programas de ação do Estado, ou seja, às políticas públicas, mas todo seu protagonismo tem acarretado inflação do órgão judicial, nesse contexto, sem aqui se pretender discutir a legitimidade desse poder para tanto, resta saber se é sustentável a existência de arranjos institucionais alternativos, para que se possa alcançar os mesmos fins.

Considerando o fenômeno da judicialização e seus impactos no princípio do acesso à justiça diante do novo CPC, Pinho e Stancati (2016, p.3), discorrem acerca do seu art.3º (não se excluirá da apreciação do poder jurisdicional ameaça ou lesão à direito), considerando que, no que pese sua semelhança com o art. $5^{\circ}, \mathrm{XXV}$ da Constituição Federal (a lei não excluirá da apreciação do Poder Judiciário lesão ou ameaça à direito), mediante leitura uma mais atenta,

\footnotetext{
${ }^{87}$ Destaque-se que o termo desjudicialização ganhou notoriedade com a edição da Lei 11.441, de 04.01.2007, a qual possibilitou a realização do inventário, partilha, separação consensual por via administrativa: "Esse desafogar do Poder Judiciário provocou de certa maneira, uma revolução nos procedimentos e nas discussões sobre o tema. Afinal, o que até então contava somente com o método judicial passou também a ser admitido na via extrajudicial." (In OLIVEIRA, Daniela Olímpio de. Desjudicialização, acesso à justiça e teoria geral do processo. $2^{\mathrm{a}}$ ed. Curitiba: Juruá, 2015, p.57).

${ }^{88}$ Em países da Europa já é comum a execução ser extrajudicial, conduzida por profissional que se assemelha ao Oficial de Justiça no Brasil, um "misto de profissional liberal e funcionário público". (In OLIVEIRA, Daniela Olímpio de. Desjudicialização, acesso à justiça e teoria geral do processo. $2^{\mathrm{a}}$ ed. Curitiba: Juruá, 2015, p.182).

${ }^{89}$ As demandas coletivas também sofreram o influxo de desvinculação de processos judiciais, com os institutos da Recomendação (Lei no 8.625/93 - Lei Orgânica do Ministério Público) e do Compromisso de Ajustamento de Conduta (Lei no 7.347/85 - Lei da Ação Civil Pública).
} 
compreendem tratar-se da oferta de uma garantia mais ampla, não restrita apenas à estrutura desse poder.

Os autores sustentam que, quando o art. $3^{\circ}$ do $\mathrm{CPC} / 2015$ se refere à apreciação jurisdicional, não está tratando somente do judiciário e sua forma imperiosa de resolver o conflito, mas sugere outras formas positivas de composição, com base no dever de cooperação das partes, podendo envolver outros atores, de forma que: "a jurisdição, que inicialmente seria entregue exclusivamente ao Poder Judiciário pode ser delegada para serventias extrajudiciais ou ser exercida por câmaras comunitárias centros ou mesmo conciliadores e mediadores extrajudiciais" (PINHO; STANCATI, 2016, p.3).

Segundo Oliveira (2015, p. 241) o acesso à justiça deixa de ser uma questão de acolhimento por um determinado órgão estatal com poder jurisdicional e se extrapola constituindo-se na existência de uma diversidade de locus e procedimentos e, mais ainda, de possibilidades efetivas de realização de valores.

A autora pontua que no Brasil, o Novo Código de Processo Civil se insere num movimento reformista que prima pela instrumentalidade das formas e realização processual dos objetivos de Estado do Direito Social (art. $1^{\circ}$ NCPC); anunciando a conciliação como razão última processual, ao destacar mais uma vez o papel instrumental da forma/procedimento em seu art. $3^{\circ}$ (OLIVEIRA, 2015, p.26): “Art. $3^{\circ} . \S^{\circ}$ O Estado promoverá, sempre que possível, a solução consensual dos conflitos".

Acerca deste movimento, Mauro Capelleti já se posicionava:

\begin{abstract}
Os juristas precisam, agora, reconhecer que as técnicas processuais servem a funções sociais; que as cortes não são a única forma de solução de conflitos a ser considerada; e que qualquer regulamentação processual, inclusive a criação ou o encorajamento de alternativas ao sistema judiciário formal tem um efeito importante sobre a forma como opera a lei substantiva. (CAPPELLETTI, 1984, p.12)
\end{abstract}

Ao realizar uma análise em relação ao núcleo essencial do princípio de acesso à justiça, a autora pondera porque o movimento pela desjudicialização se enquadraria nesse núcleo, uma vez que referido princípio merece ser analisado conforme seus desdobramentos, que baseandose na obra de Carneiro ${ }^{90}$, seriam a acessibilidade, operosidade, utilidade e proporcionalidade.

\footnotetext{
${ }^{90} \mathrm{~A}$ autora destaca a tentativa de Paulo Cezar Pinheiro Carneiro em precisar um núcleo valorativo para o sentido principiológico da expressão "acesso à justiça", os enumerando em: "i) acessibilidade, relacionada à capacidade de estar em juízo sem qualquer obstáculo - pressupõe direto a informação, a uma legitimação adequada, bem como a possibilidade dos custos processuais; ii) operosidade, relacionada a atuação ética e técnica das pessoas envolvidas, direta ou indiretamente, na atividade judicial, ou até mesmo, extrajudicial;iii) utilidade, empregada no sentido de efetividade da prestação jurisdicional - reexamina-se aqui, temas como coisa julgada, nulidades processuais, utilidade na execução, enfim,a própria temática da instrumentalidade do processo e a extensão da jurisdição sob o ponto de vista subjetivo; e, por fim, iv) proporcionalidade, com o imperativo de se empregar seus subprincípios com a maior precisão possível, de forma a harmonizar a atividade jurisdicional à norma
} 
Quanto ao sentido de acessibilidade, destaca o Judiciário como órgão presente e atuante, ao lado das demais vias de promoção do justo, "não mais como órgão único, ou primeiro, mas ainda como órgão último da proteção dos princípios fundamentais” (OLIVEIRA, 2015, p.30).

A operosidade estaria relacionada a melhor técnica, inclusive pelo aporte de mecanismos extrajudiciais, com a ética na condução desses processos pelos atores envolvidos, nesse sentido, o movimento pela desjudicialização, poderia apresentar-se como melhor técnica, como medida encontrada em alguns procedimentos que desafogam o judiciário e também promovam a pacificação social (OLIVEIRA, 2015, p.30)

Quanto ao aspecto da utilidade a autora pontua que não raras vezes, a mediação mostra respostas mais úteis à solução de conflitos de natureza continuada (família, vizinhança, etc.), sendo mais efetivo, socialmente falando, do que a atuação judicial, sub-rogatória. E finalmente, na proporcionalidade, considerando a abertura das vias pacificadoras com a multiplicidade dos espaços públicos, inclusive de processualidade na Administração Pública, a razoabilidade motiva a eliminação de demandas desnecessárias antes mesmo da apreciação tradicional do Poder Judiciário.

[...] Esses meios não retiram o controle jurisdicional da lesão ou ameaça de lesão a direitos individuais. Portanto, são formas necessárias, pelo desafogar judicial e pela realização efetiva do acesso à ordem jurídica justa; adequadas, assim concebidas sempre que promovem mesmo a pacificação social, e proporcionais em sentido estrito, na medida em que a estas vias alternativas não se elimina o acesso ao judiciário, preservando-se essa instituição e consolidando seu agir (OLIVEIRA, 2015, p. 34).

Especificamente quanto aos meios de soluções de conflitos, podemos classificá-los em dois grupos: autocomposição (conciliação e mediação) e heterocomposição (arbitragem e jurisdição). A mediação passou a se desenvolver como instrumento para resolução extrajudicial de conflitos em meados dos anos 70, nos EUA, como Alternative Dispute Resolution (ADR). Embora não haja um veículo legal específico sobre o tema, consiste numa técnica antiga, que remonta a Constituição do Império, de $1824^{91}$, tratando-se de uma forma de composição

constitucional." (In CARNEIRO, Paulo César Pinheiro. Acesso à Justiça: juizados especiais cíveis e Ação Civil Pública: uma nova sistematização da Teoria Geral do Processo. 2. ed. rev. e atual. Rio de Janeiro: Forense, 2007.) ${ }^{91}$ Conforme consta na Constituição de 1824: “Art.160. Nas cíveis, e nas penais civilmente intentadas, poderão as Partes nomear Juízes Arbitros. Suas sentenças serão executadas sem recurso, se assim o convencionarem as Partes". "Art. 161. Sem se fazer constar, que se tem intentado o meio da reconciliação, não se começará Processo algum”. (In BRASIL. Constituição (1824). Constituição Política do Império do Brasil, elaborada por um Conselho de Estado e outorgada pelo Imperador D. Pedro I, em 25.03.1824. Disponível em: <http://www2.camara.leg.br/>. Acesso em 10 jan 2019). 
voluntária de conflitos onde os interessados buscam a necessária intervenção de um terceiro imparcial, sem interesse direto na demanda (OLIVEIRA, 2015, p.54) ${ }^{92}$.

Um terceiro mediador imparcial, com poder de decisão limitado, não jurisdicional, auxiliará as partes envolvidas a chegarem a uma composição voluntária com relação às questões postas em situação de confronto, conforme ressalta Humberto Dalla Bernardina de Pinho (2005, p.107):

\begin{abstract}
O papel do interventor é ajudar na comunicação através da neutralização de emoções, formação de opções e negociação de acordos. Como agente fora do contexto conflituoso, funciona como um catalizador de disputas, ao conduzir as partes às suas soluções, sem propriamente interferir na substância destas.
\end{abstract}

A mediação se impõe como uma possibilidade de tratamento do conflito, ou como estratégia para afastar a litigiosidade existente; com sua inserção prima-se por uma cultura de paz, e possibilita-se criar de um espaço de tratamento de conflitos na comunidade, contribuindo para a redução de processos no Poder Judiciário, sendo uma das formas através do qual é possível se alcançar a desjudicialização, inclusive na área da saúde.

Os Modelos Alternativos de Resolução de Conflitos representam a adesão à cultura da pacificação, em oposição à cultura da litigiosidade, sendo a solução pacífica sempre preferível, inclusive economicamente, o que não impede a busca posterior pelo aparato judicial. Existe uma atmosfera favorável para tais modelos, que também constituem instância legitimada para a solução de conflitos sociais pelo próprio meio social, refletindo maior conscientização política e participação popular (DELDUQUE; CASTRO, 2015). ${ }^{93}$

Reconhecendo-se a existência de três formas distintas de resolução de conflitos: a) as resoluções estatais - ou heterocomposição dos conflitos, através das decisões judiciais; b) as resoluções estatais negociadas com as partes - ou autocomposição, que podem se dar previamente ao início do processo, no âmbito jurisdicional, ou no âmbito de órgãos auxiliares

\footnotetext{
${ }^{92}$ Acerca do conceito de mediação, a Diretiva 2008/52 da Comunidade Europeia entende tratar-sede "um procedimento estruturado, seja qual for seu nome ou denominação, em que duas ou mais partes em litígio tentam voluntariamente alcançar por si mesmas um acordo sobre a resolução de um litígio com a ajuda de um mediador." UNIÃO EUROPEIA, 2008.Disponível em: <https://eurlex.europa.eu/LexUriServ/LexUriServ.do?uri=OJ:L:2008:136:0003:0008:PT:PDF>. Acesso em 10 jan 2019.

${ }^{93}$ Os autores ressaltam que: “A questão ganha maior importância frente à Resolução 127 do Conselho Nacional de Justiça (CNJ), conhecida como Política Judiciária Nacional, que, entre outras medidas, prevê o movimento pela conciliação.Desde 2006, a Secretaria de Reforma do Judiciário (SRJ), do Ministério da Justiça, em ação conjunta com o CNJ, vem capacitando mediadores por meio da Escola Nacional de Mediação e Conciliação (Enam), com o intuito de realizar uma lenta transformação da sociedade brasileira, no sentido de criar a cultura do consenso e da cooperação na composição das disputas, aceitando-se um polissêmico conceito de justiça. Os sucessivos cursos de mediadores são voltados para operadores do direito, membros da academia e da sociedade civil." (In DELDUQUE, Maria Célia. CASTRO, Eduardo Vazquez de. A mediação sanitária como alternativa viável à judicialização das políticas de saúde no Brasil. Saúde Debate. Rio de Janeiro. v. 39. n.105. p.50. Abri-jun, 2015).
} 
da justiça, como o Ministério Público, a Defensoria Pública e a Advocacia Geral da União; e c) a resolução dos conflitos - ou autocomposição dos conflitos -, no âmbito extrajudicial, privado ou não; a Mediação Sanitária consistiria um modelo alternativo de resolução de conflitos na área da saúde, considerando que:

[...] As relações em saúde transcendem a ótica bilateral do médico com o paciente, para envolver muitos outros atores presentes em um sistema de saúde, advindo, daí conflitos de toda a ordem, internos e externos ao sistema, criando condições para a judicialização. Conflitos internos (como os assistenciais, organizativos e conflitos entre profissionais) geram desgastes e judicialização, como também fazem os conflitos gerados fora do sistema, mas com reflexos diretos dentro dele, assim como os conflitos sociais e conflitos legais igualmente geram a judicialização (DELDUQUE; CASTRO, 2015, p. 50).

A construção de núcleos de Mediação Sanitária, no âmbito das Secretarias de Saúde, em todos os níveis, para operar a Mediação interna ao sistema e externa com seus usuários, surge como novo paradigma a substituir a litigância e a judicialização. O SUS tem recebido preciosa ajuda dessa forma de resolução de conflitos, com dignas iniciativas de juízes, membros do Ministério Público, defensores públicos e advogados da União e procuradores, que, instituindo grupos de Mediação, realizam um trabalho a partir da demanda individual, para mediar o conflito entre o paciente/autor e o gestor da saúde, com o intuito de evitar a ação judicial. Dois exemplos exitosos da utilização da Mediação na área da saúde, no Brasil, ocorrem no Ministério Público de Minas Gerais e na Defensoria Pública do Distrito Federal:

[...] Em Brasília, a Câmara Permanente Distrital de Mediação em Saúde, da Defensoria Pública do DF, tem por objetivo mediar conflitos entre os pacientes usuários do SUS-DF e os gestores da rede pública de saúde da Capital. No Estado de Minas Gerais, o Centro de Apoio Operacional das Promotorias de Justiça de Defesa da Saúde percorre regiões do estado realizando reuniões de conciliação entre usuários e gestores, além de tratar de temas específicos, como saúde prisional, incorporação tecnológica e outros (DELDUQUE; CASTRO, 2015, p. 50).

Apesar de se considerar a ação coletiva como um mecanismo por excelência de diálogo institucional, no campo das demandas individuais, vislumbra-se duas formas por meio das quais a ideia do diálogo poderia se inserir, uma delas, na tentativa de elaboração de parâmetros decisórios mais formais, que levem em conta a exigência de um procedimento correto, ao invés da busca de uma resposta adequada por meio de uma angustiante ponderação casuística entre o mínimo existencial e a reserva do possível sendo a observância da lista de medicamentos (RENAME) um exemplo eloquente dessa forma de proceder (SOUZA, 2011). Conforme observado no item 3.4, diversos critérios de ordem formal em matéria de judicialização da saúde estão à disposição do julgador a fim de possibilitar uma autocontenção judicial. 
A segunda forma de se inserir a base teórica do diálogo nos casos das demandas individuais estaria relacionada com a possibilidade de imaginar desenhos institucionais que aumentassem a cooperação entre os agentes envolvidos na decisão e, dessa forma, potencializassem as possibilidades de melhores respostas. Observando-se no país a existência de ações conjuntas das Defensorias Públicas, do Judiciário e do Executivo e dos especialistas da área de saúde visando a redução das demandas judiciais e o esclarecimento do julgador no momento de decidir (SOUZA, 2011).

Através do diálogo entre as instituições, pode-se fomentar um ambiente de desjudicialização, sobretudo na área da saúde. No que se refere especificamente ao combate à judicialização excessiva na área da saúde, tem se adotado novas estratégias de desjudicialização, através da adoção de arranjos institucionais como os meios informais e recursos a não juristas nos processos em tribunal (NAT'S) ou a transferência de competência de resolução de litígios para instâncias não judiciais (p.ex. Núcleos da Defensoria conveniados com Secretarias Estaduais e Municipais de Saúde).

Como foi visto, o acesso à justiça não pode estar adstrito à via judicial, uma vez que os conflitos podem ser solucionados por meios alternativos, ainda no âmbito de órgãos auxiliares da justiça, através da mediação sanitária. Ainda, à luz dos diálogos institucionais, no âmbito judicial, referido acesso poderá ser "qualificado", através da interação e auxílio de atores do sistema de saúde, visando dotar essas decisões judiciais de maior efetividade. Nos próximos tópicos se dará o estudo de estratégias de desjudicialização que se sustentam no diálogo institucional e são desenvolvidos no âmbito do Estado do Ceará.

\subsection{As experiências de desjudicialização como medidas de efetivação da saúde}

Constitui objetivo do presente tópico, compreender os arranjos institucionais desenvolvidos em experiências específicas de interação entre Defensorias Públicas, Judiciário, Executivo e especialistas na área da saúde visando a redução de demandas judiciais e o esclarecimento do julgador. Cumpre dar a conhecer algumas das experiências importantes que dizem da interação do sistema sanitário e do sistema de justiça e que alcançaram resultados exitosos. Não há pretensão de esgotar a apresentação das estratégias existentes e muitas delas exitosas. Trata-se apenas de apresentação exemplificativa de experiências, ora coordenadas pelos gestores de saúde, ora coordenadas por operadores do sistema de justiça - todavia, com a participação importante e essencial dos atores envolvidos. 
Antes de adentrar-se especificamente a este tema, cumpre ressaltar os esforços em todo o país pelo aprimoramento na organização das Secretarias Estaduais de Saúde especialmente para enfrentar os desafios impostos pela judicialização da saúde. Os esforços dizem tanto da organização interna de referidas secretarias quanto das relações que se estabelecem com o sistema de justiça.

Em todo o Brasil, há experiências ricas e cada uma delas guarda singularidade com a realidade local, com as condições de cada secretaria, com a natureza dos conflitos e outros fatores (CONASS, 2015, p.79):

[...] importa mencionar que, por vezes, há características relativas à gestão que também levam à judicialização de itens expressos na política de saúde. A organização e o desempenho dos setores responsáveis por aquisição e dispensação de itens, controles de estoques, contratação e pagamento à fornecedores, regulação de acesso aos serviços especializados têm forte impacto na judicialização e, por isso, devem ser foco de atenção dos gestores estaduais. Por vezes, organização, qualificação, alcance e melhoria de desempenho desses setores vitais ao bom funcionamento das secretarias estaduais de saúde apresentam entraves que dizem respeito exclusivamente ao sistema sanitário e que, resolvidos, implicarão melhor atendimento aos usuários do SUS e diminuição de processos judiciais.

Nesse contexto, a gestão estadual deve se preparar para debater com o sistema de justiça os temas que estão em voga, como a responsabilidade dos Entes, a organização das normativas do SUS, o bloqueio de verbas públicas, a "diferença de classe”. A fim de debater sobre: “( $i$ o que está e porque está na política; (ii) o que não está nem deveria estar na política; e (iii) o que não está e deve ser avaliado", a gestão estadual deve fortalecer suas instâncias administrativas e executoras, assim como deve adequar-se às melhores estratégias de relação com o sistema de justiça - sejam elas modeladas e coordenadas pelo sistema sanitário ou não (CONASS, 2015).

A gestão estadual deve ainda sensibilizar as procuradorias estaduais afim de que, assim como os componentes do sistema de justiça, haja procuradores especialistas em Direito Sanitário e conhecedores da gestão da política pública e que, em sendo necessário, contem com equipes multidisciplinares das SES. Devendo investir em formação de equipes, tanto para o que o Direito Sanitário abrange, quanto para métodos e estratégias de solução extrajudicial de conflitos (CONASS, 2015).

Pontarolli et al.(2015) narram o processo de organização da Secretaria Estadual de Saúde do Paraná para o atendimento das solicitações judiciais de medicamentos e outras demandas, descrevendo: (i) o "passo a passo" dessa organização e apresentam seu respectivo fluxo; (ii) o desenvolvimento de software auxiliar (Sismedex); e (iii) os dados de referida secretaria relativos à demandas judiciais por medicamentos, concluindo que: 
[...] as demandas judiciais são consideradas um dos grandes desafios para os gestores do Sistema Único de Saúde, independentemente da esfera de gestão onde atuem. [...] Trata-se de uma questão complexa e multifacetada, que envolve múltiplos saberes. Dessa forma, é fundamental que se busquem o diálogo e o consenso entre os usuários, os gestores de saúde e os operadores do direito para que efetivem, concomitantemente, o direito à saúde e o fortalecimento do Sistema Único de Saúde Pontarolli et al. (2015, p. 10).

Nantes e Dobashi (2015, p.03) discutem a judicialização no estado do Mato Grosso do Sul e as iniciativas adotadas pela respectiva Secretaria Estadual de Saúde para seu enfrentamento desta, destacando que:

[...] a partir de 2005, foi instalado importante processo de descentralização e especialização, com a lotação de Procuradores nas Secretarias onde as demandas eram maiores e mais específicas. A primeira experiência foi na Secretaria Estadual de Saúde que, àquela altura, já demonstrava números crescentes de ações judiciais. Essa decisão foi influenciada pelos debates realizados em um evento ocorrido no final de 2004, que reuniu Juízes, Promotores, Defensores Públicos, Procuradores, Gestores de Saúde dos municípios pólo de região e técnicos federais, estaduais e municipais da área de saúde.

No Ceará, as despesas oriundas do processo de judicialização de ações e serviços de saúde financiadas através dos recursos do Tesouro Estadual apresentam tendência de crescimento no período de 2009 a 2014, alcançando nesse último ano o valor de $\mathrm{R} \$ 90.134$ mil, a preços correntes. Com a implantação das estratégias de trabalho articulado com o Poder Judiciário e da melhoria dos processos de trabalho na SESA em 2015, essa despesa reduziu para $\mathrm{R}$ \$45.380mil, representando uma redução de 49,7\% em relação a 2014 (COELHO; LIMA, 2018, p. 46).

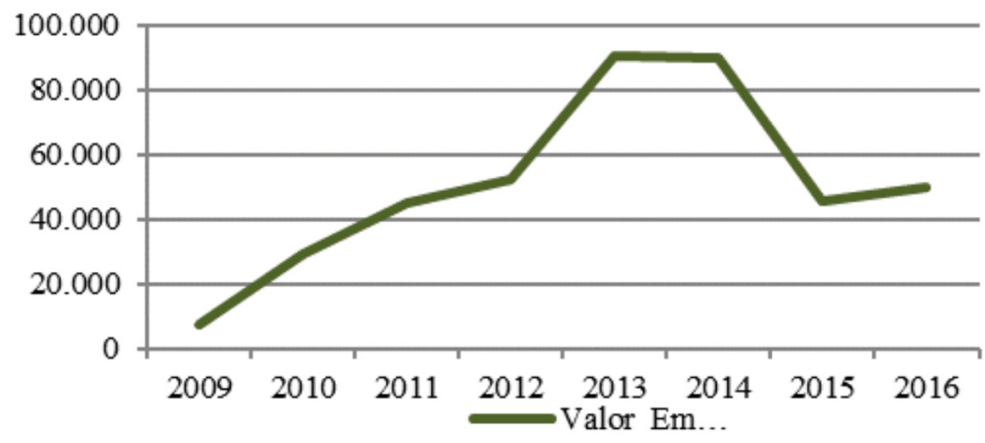

Fonte: Relatório Ceará 2050. Estudo setorial especial Saúde.

Para minimizar os problemas com a judicialização da saúde, a Secretaria de Saúde do Estado do Ceará(SESA) adotou algumas medidas, tais como a criação do Núcleo de Processos Judiciais junto à Assessoria Jurídica da SESA, com o fim especial de agilizar o atendimento das demandas judiciais referentes a medicamentos, dietas, procedimentos cirúrgicos, UTIs, outros insumos típicos da área da saúde e realização de instrução dos processos com vistas à 
defesa do Estado. Outra medida adotada consistiu na chamada "remodelação" do núcleo de planejamento de compras, ou seja, adotaram-se pregões em escala no intuito de reduzir as despesas, obtendo preço mais acessíveis para a administração estatal (PASSOS; GOMES, 2017)

Segundo informações obtidas junto à Assessoria de Comunicação (ASCOM) da Secretaria de Saúde do Estado do Ceará (SESA), referido órgão firmou parceria com a Defensoria Pública do Estado, em maio de 2016, para evitar a judicialização das demandas de saúde e solucioná-las de forma administrativa ${ }^{94}$. A solicitação mais comum na área da saúde seria a demanda por medicamentos para pacientes em tratamento de câncer, osteoporose, fibrose cística e doenças raras, não constantes na Relação Nacional de Medicamentos (Rename) para fornecimento gratuito pelo SUS ou com distribuição não regulamentada pela ANVISA. O número de demandas judiciais decrescera de 5.461, em 2015, para 4.053 em 2016.

No mesmo ano, a Secretaria de Saúde ampliou as categorias de compras centralizadas para insumos da saúde e serviços, visando ampliar a capacidade de controle de estoques de medicamentos e material médico-hospitalar das unidades assistenciais. Tal centralização possibilitou o remanejamento de estoques de maneira mais rápida, permitindo a adequação da demanda ao paciente, essa medida reduziu o volume de estoques em $15 \%$ e normatizou as compras para períodos de aquisição mais curtos ${ }^{95}$.

Quanto à judicialização da assistência farmacêutica, no quadro da Secretaria de Saúde do Estado, existe a Coordenadoria de Assistência Farmacêutica (COASF), que se divide nos seguintes núcleos:

a) Numes: núcleo de medicamentos essenciais;

b) Numex: núcleo de medicamentos excepcionais ou especializados;

c) Nufito: núcleo de medicamentos fitoterápicos, e o Ceadim (central de armazenamento de distribuição de imunobiológicos),

d) Setor de demandas judiciais: que atua no planejamento, gerenciamento e distribuição dos medicamentos judicializados (CEARÁ, 2016, p. 125-126).

Atualmente existem cerca de 750 apresentações de medicamentos no elenco de medicamentos judicializados, o que representa um gasto médio anual de aproximadamente $\mathrm{r} \$$ 50.000.000,00 (dados entre 2011 e 2014). Os profissionais do setor atuam de forma integrada aos demais setores da coordenadoria de assistência farmacêutica assim como outros órgãos da

\footnotetext{
${ }^{94}$ Tal iniciativa será estudada de forma mais detalhada no tópico 4.3.2 da presente dissertação.

${ }^{95}$ Conforme informações fornecidas pela referida assessoria da Secretaria de Saúde do Estado (SESA), a metodologia permitiu um melhor abastecimento e com maior homogeneidade, além da economia direta com um incremento de apenas $2 \%$ em relação a 2015, em uma realidade que a curva inflacionária média orbitou sempre acima de $10 \mathrm{pp}$, além do que fora absorvido quase $\mathrm{R} \$ 50.000,00$ em judicialização nesta conta.
} 
secretaria da saúde e procuradoria geral do estado, sendo que a judicialização de medicamentos representa importante papel na execução orçamentária da coordenadoria de assistência farmacêutica, o que demanda o desenvolvimento de estratégias administrativas para diminuir as ações judiciais com máxima eficiência no atendimento dos pacientes que necessitam de medicamentos importados, inovadores, não padronizados ou que apresentem dificuldades na regulação de acesso (CEARÁ, 2016).

Os aspectos estratégicos e operacionais considerados de vital importância na implantação da política de Assistência Farmacêutica são: Articulação Intersetorial e Desenvolvimento Institucional; Assessoria Técnica e/ou Cooperação Técnica; Desenvolvimento e Logística; Desenvolvimento do Sistema de Informação (apoio na implantação do sistema HORUS- sistema de controle de estoque do Ministério da Saúde); Capacitação dos Recursos Humanos e Promoção do Uso Racional de Medicamentos. (CEARÁ, 2016).

Alguns arranjos institucionais constituídos no Estado do Ceará permitiram o investimento dos atores políticos, jurídicos e da área da saúde na prevenção dos conflitos, e quando existentes, na sua resolução extrajudicial. Contudo, apesar de haver bastante expectativa com relação a redução no número de processos judiciais envolvendo questões de saúde pública e a divulgação por parte da Secretaria de Saúde do Estado do Ceará de que um desses arranjos estaria a gerar uma significativa economia aos cofres públicos, resta indagar como funcionam e seu potencial impacto no cenário da política pública de saúde.

Serão estudados ao longo dos próximos tópicos o Núcleo de Apoio Técnico ao Judiciário (NATJUS) e no Núcleo de Atendimento Inicial em Saúde (NAIS), que funcionam como mecanismos de fomento ao diálogo institucional.

Imprescindível tecer considerações acerca das pessoas e instituições envolvidas no esforço pela desjudicialização das ações que versam sobre o direito fundamental à saúde, a fim de que se possa conhecer o perfil de cada um dos atores desse complexo problema jurisdicional, bem como conhecer os meios alternativos de resolução extrajudicial dos conflitos de interesses.

Nos tópicos seguintes, analisa-se o resultado de pesquisa bibliográfica e de visitas realizadas para obtenção de material de pesquisa junto a esses espaços de diálogo interinstitucional. Esses arranjos serão discutidos a partir de quatro elementos: a) surgimento e legislação; b) atores envolvidos; c) forma de atuação; d) principais obstáculos; d) resultados obtidos. 


\subsubsection{O Núcleo de Apoio Técnico ao Judiciário (NATJUS) no Estado do Ceará}

Os NAT's surgiram a partir da necessidade de uma compreensão multidisciplinar a respeito da saúde e direito, e foram implementados nos diversos tribunais do país com o propósito primordialmente ${ }^{96}$ consultivo, como forma de auxíliar aos juízes na formação de sua convicção nos litígios de saúde.

Após a audiência Pública nº 04/09, através da Resolução nº 107, de 06 de abril de 2010, o CNJ instituiu o Fórum Nacional para o monitoramento e resolução das demandas de assistência à saúde, com a atribuição de elaborar estudos e propor medidas concretas e normativas para o aperfeiçoamento de procedimentos, o reforço à efetividade dos processos judiciais e à prevenção de novos conflitos. Para o funcionamento descentralizado do Fórum, foram criados os Comitês Executivos Estaduais, sob a coordenação de magistrados indicados pela Presidência e/ou pela Corregedoria Nacional de Justiça, como o objetivo de coordenar e executar as ações de natureza específica, que forem consideradas relevantes (art. $3^{\circ}$ da Resolução no 107/2010).

Considerando o expressivo volume processual, ainda em 2010, o CNJ publicou a Recomendação $n^{\circ} 31$, que teve como objetivo orientar os tribunais na adoção de medidas que subsidiassem os magistrados para assegurar maior eficiência na resolução das demandas judiciais envolvendo assistência à saúde pública. Dessa forma, referido conselho estimulou que os tribunais, entre outras medidas, celebrassem convênios com o objetivo de disponibilizar apoio técnico composto por médicos e farmacêuticos para auxiliá-los na apreciação das questões clínicas apresentadas pelas partes observadas as peculiaridades regionais.

O CNJ dispôs por meio da Resolução no 238 de 06/09/2016 sobre a criação e a manutenção, pelos Tribunais de Justiça e Regionais Federais de Comitês Estaduais da Saúde, bem como a especialização de vara em comarcas com mais de uma vara da Fazenda Pública. Em seu art. $1^{\circ}$, referida resolução determina que os Comitês Estaduais da Saúde, tem entre as suas atribuições auxiliar os tribunais na criação de Núcleos de Apoio Técnico do Judiciário (NAT'S).

No âmbito do Estado do Ceará, o Comitê Executivo foi instalado no dia 22 de março de 2011, e em atendimento a Recomendação no 31, foi criado, em 11 de novembro de 2016, o

\footnotetext{
${ }^{96}$ Em alguns estados, o NAT exerce também atividades de resolução administrativa de conflitos como no caso do NAT de Araguaiana - Tocantins, que por meio da Ouvidoria Municipal, estimula o diálogo entre o Ministério Público, Defensoria Pública e Secretaria Municipal de Saúde antes do ajuizamento da ação, resultando na resolução administrativa do litígio e evitando, por conseguinte, a judicialização (CNJ, 2014).
} 
Núcleo de Apoio Técnico ao Judiciário do Ceará - NAT-JUS/CE, através do Termo de Cooperação Técnica nº 07/2016 firmado entre o Tribunal de Justiça do Ceará, Hospital Universitário Walter Cantídio - UFC/EBSERH (representando a União), o Estado do Ceará e o Município de Fortaleza.

Como experiência inovadora de efetivação do direito à saúde, o NAT-JUS/CE tem como objetivo o atendimento às solicitações de esclarecimentos em ações judiciais que envolvam prestação de assistência à saúde no Sistema Único de Saúde - SUS. A equipe técnica é formada por profissionais das Secretarias de Saúde (do Estado e do Município) presta as informações aos magistrados sob a coordenação do Comitê Executivo Estadual de Saúde, que viabiliza, também, um sítio eletrônico ${ }^{97}$ disponibilizado aos magistrados, conforme prevê o art. 2 da Resolução no 238 do CNJ.

No Estado, o sistema pode ser consultado por Magistrados das Varas e Juizados da Fazenda Pública da Comarca de Fortaleza, Magistrados da Turma Recursal da Fazenda Pública da Comarca de Fortaleza e Desembargadores das Câmaras Cíveis de Direito Público do Tribunal de Justiça do Ceará. Em sua solicitação, via e-mail, o Magistrado/Desembargador deverá faz seus questionamentos de forma clara e objetiva, anexando todos os documentos médicos que envolvam a demanda (laudo médico, exames, relatórios médicos etc).

Os documentos técnicos solicitados pelo TJCE são entregues em cinco dias úteis a partir da data do recebimento da solicitação, conforme Termo de Cooperação Técnica no 07/2016. A prestação de serviços atualmente é realizada por doze membros, sendo seis médicos e seis farmacêuticos ${ }^{98}$ e o parecer consultivo contempla as seguintes informações: a) análise do caso concreto apresentado no processo judicial para o qual será elaborado o parecer; b) mapeamento bibliográfico específico para cada caso, por profissional devidamente qualificado; c) informações sobre a possibilidade de substituição do medicamento ou do procedimento médico prescrito por outro fornecido pelo SUS, e em caso negativo, a justificativa para a não utilização do protocolo do SUS. Nos pareceres costumam constar considerações sobre a eficácia e evidências científicas dos tratamentos disponibilizados pelo SUS, sobre seu registro na Anvisa, incorporação pelo Conitec, sobre a presença de Protocolo Clínico e Diretrizes Terapêuticas

\footnotetext{
${ }^{97} \mathrm{O}$ sítio eletrônico elaborado pelo Tribunal de Justiça do Estado do Ceará (<https://www.tjce.jus.br/saude/>, conta com informações relevantes sobre as reuniões do Comitê Executivo da Saúde e pode servir de auxílio aos magistrados, na medida em que disponibiliza legislação correlata à saúde pública e suplementar, modelo de relatório médico para a judicialização, sentenças e decisões, indicações de sites para pesquisa, bem como as 202 notas técnicas até então emitidas pelo NATJUS-CE de livre acesso.

${ }^{98}$ O NATJUS-CE é composto pelo corpo técnico de 6 médicos e 6 farmacêuticos, conta com a Juíza Coordenadora e um agente terceirado do Tribunal de Justiça do Estado do Ceará (TJCE).
} 
(PCDT) do Ministério da Saúde ou de órgão público, e também informações sobre o custo da medicação, dentre outros.

Até então foram emitidas 202 notas técnicas que podem ser consultadas por qualquer cidadão no portal $^{99}$ do Tribunal de Justiça do Ceará (TJCE). As consultas não estão adstritas apenas a medicamentos, mas a tratamentos e até cirurgias. A forma de contato dos membros do NAT-JUS com os magistrados se dá de maneira informal, através de e-mail ou telefone, um agente terceirizado pertencente ao Tribunal de Justiça (TJCE) é responsável por facilitar o diálogo, intermediando em algumas ocasiões a relação entre membros do Tribunal e o corpo técnico do NATJUS-CE.

Contando com estrutura de sala própria e três computadores, as atividades do NAJUSCE são feitas em atendimento ao Princípio da Publicidade, com a divulgação das notas técnicas em sítios eletrônicos, bem como o da Impessoalidade, uma vez que os integrantes do NATJUSCE não tem contato nem com as partes ${ }^{100}$, nem com seus advogados, além disso, a autoria das notas técnicas não se atribui a um parecerista específico, mas à todo o corpo técnico.

Impende ressaltar que, ainda conforme Termo de Cooperação Técnica nº 07/2016, há prioridade em se conceder tratamentos ou medicamentos que já seja fornecido regularmente pelo SUS, medida que tende a fortalecer a política pública de saúde. Entende-se a importância do auxílio aos magistrados nesses casos, pois possibilidade de consulta à uma equipe especializada permite o deferimento de um substitutivo, que seja disponibilizado pelo SUS e que seja menos oneroso aos cofres estatais, como pode se verificar no caso a seguir.

Nos autos do processo, no 0143312-96.2017.8.06.0001, o Exmo. Sr. Juiz Dr. Francisco Eduardo Fontenele Batista, da $15^{\mathrm{a}}$ Vara da Fazenda Pública da Comarca de Fortaleza, solicitou esclarecimentos acerca da demanda de medicamento (omeprazol magnésico-LOSECMUPS®) para tratamento de criança de 13 anos com diagnóstico de esofagite erosiva leve (CID 10: K20) e gastrite crônica leve (CID 10: K29.5). Segundo informações médicas constantes nos autos, por ser portadora de uma síndrome genética (CID 10: Q90), associada a déficit cognitivo CID 10:F72), a criança não conseguia deglutir comprimidos, sendo que a solicitação indicava o uso de omeprazol magnésico, 20mg/dia, por 90 dias. De acordo com laudo médico, não haveriam outras medicações substitutivo do tratamento receitado, pois o omeprazol magnésico seria o

\footnotetext{
${ }^{99} \mathrm{Em}$ atendimento à Res. 238/16, que assim dispõe: “Art. $2^{\circ}$ Os tribunais criarão sítio eletrônico que permita o acesso ao banco de dados com pareceres, notas técnicas e julgados na área da saúde, para consulta pelos Magistrados e demais operadores do Direito, que será criado e mantido por este Conselho Nacional de Justiça." Uma série de informações para subsidiar magistrados encontram-se disponíveis no endereço eletrônico: <https://www.tjce.jus.br/saude/>.Acesso em: $05 \mathrm{dez} 2018$.

${ }^{100}$ Ressalte-se, contudo que, o membro responsável pela Coordenação do NATJUS-CE também coordena o Comitê Estadual de Saúde, o que resulta em uma interação entre os Poderes Judiciário e Executivo.
} 
único omeprazol passível de diluição. Todavia, o Parecer nº 161 do NATJUS-CE foi conclusivo no sentido de que:

[...] O tratamento da paciente poderá ser feito pelo SUS, com omeprazol convencional, uma vez que, segundo a bula do medicamento 'para pacientes que tiverem dificuldade em engolir, as cápsulas podem ser abertas e os microgrânulos intactos misturados com pequena quantidade de água fria e tomados imediatamente".Não há justificativa plausível para o uso de omeprazol magnésico (LOSEC MUPS®) em substituição ao omeprazol convencional disponibilizado no SUS.' ${ }^{101}$

Convém ressaltar que as atividades do NATJUS-CE estão restritas aos pareceres em matéria de saúde pública, pois conforme informações obtidas junto ao convênio, seria necessário um aumento no corpo técnico para atender a demanda também referente a saúde complementar, para isso vêm-se tentando celebrar convênios com outras instituições a fim de que forneçam profissionais; ressaltando que os funcionários que fazem parte do NATJUS-CE não são cedidos, continuam vinculados ao seu órgão de origem e tem apenas parte de sua carga horária disponibilizada para o Núcleo.

Expandir o NATJUS-CE para todas as zonas judiciárias, consiste atualmente num grande desafio, considerando-se seu reduzido corpo técnico, que não consta com dedicação integral. No ano de 2018, houve a expansão do NATJUS-CE para atender a Região Metropolitana e outros municípios, podendo contar com seu auxílio, as comarcas de Caucaia, Maranguape, Pacatuba, Aquiraz, Maracanaú, Eusébio, Itaitinga, Guaiúba, Chorozinho, Pacajus, São Gonçalo do Amarante, Horizonte, Pindoretama, Cascavel, Paracuru, Paraipaba, Trairí e Umirim.

Na Comarca de Fortaleza, com a instalação de duas varas especializadas em saúde, a $9^{a}$ e a $15^{\mathrm{a}}$ Vara da Fazenda Pública, no segundo semestre de 2018, os processos envolvendo saúde parte dos processos passaram a se concentrar nessas varas, enquanto os demais, que possuem rito próprio, continuam a tramitar nos três Juizados da Fazenda Pública. A solicitação de pareceres também pode realizada por Desembargadores que julgam processos relacionados a saúde.

A especialização de varas é uma boa iniciativa na medida em que gera uma economia na capacitação dos julgadores, contudo tem sido criticado por alguns pois tenderia a incentivar demandantes e advogados à cultura do litígio.

\footnotetext{
${ }^{101}$ Disponível em: https://www.tjce.jus.br/wp-content/uploads/2018/10/OMEPRAZOL-MAGN\% C3\%89SICO-LOSEC-MUPS\%C2\%AE-PARA-TRATAMENTO-DE-ESOFAGITE-EROSIVA-E-GASTRITECR\%C3\%94NICA-LEVE.pdf. Acesso em: 15 jan 2018.
} 
Embora não se possa afirmar com base nos dados obtidos juntos ao NATJUS-CE, se a iniciativa causou impacto na judicialização em termos numéricos, foi possível constatar que essa iniciativa cumpre seu papel quanto à capacitação e aperfeiçoamento da magistratura em matéria de saúde, sendo proporcionados encontros e reuniões dos magistrados com membros do NATJUS-CE, assim como há constante capacitação de seus membros em cursos EAD organizados pelo Conselho Nacional de Justiça (CNJ).

No âmbito do Tribunal de Justiça do Estado do Ceará tem-se promovido cursos de aperfeiçoamento para a magistratura nas demandas relacionadas ao Direito à saúde, como o "Curso de Direito à Saúde", que se deu no mês de maio de 2018, no Tribunal de Justiça do Ceará (TJCE), de iniciativa da Escola Superior da Magistratura do Ceará (Esmec), em parceria com o Núcleo de Apoio Técnico ao Judiciário do Estado (NAT-JUS), com o objetivo de promover o aperfeiçoamento de magistrados e servidores em temas relacionados à matéria, como o fornecimento de medicamentos, tratamentos, entre outros ${ }^{102}$.

Nos meses de junho a agosto de 2018, foi promovido pelo Núcleo Permanente de Métodos Consensuais de Solução de Conflitos do Tribunal de Justiça do Estado do Ceará o I Curso de Mediação em Saúde, também visando a capacitação, de magistrados e servidores, em temas relevantes sobre direito à saúde, como a judicialização, saúde pública e saúde suplementar, bem como aprimorar as técnicas de mediação relacionadas às demandas desta natureza, possibilitando ao conciliador e ao mediador realizar as sessões envolvendo Entes Públicos e planos de saúde com maior assertividade e conhecimento técnico. No referido curso houve a formação de 30 mediadores, e, conforme informação obtida junto ao NATJUS-CE faz parte da programação do TJCE, como próxima etapa do enfrentamento à judicialização a criação de câmaras de mediação em saúde.

\subsubsection{O Núcleo de Atendimento Inicial em Saúde (NAIS) no Estado do Ceará}

Ao longo da última década, as Defensorias Públicas de diversos estados brasileiros, bem como a Defensoria Pública da União (DPU), se organizaram para atender à crescente demanda por serviços de saúde negados pelo SUS. Os cidadãos assistidos passaram a ser atendidos junto aos núcleos de atendimento de demandas cíveis (caso da DPU), em núcleos especializados em direitos humanos (caso de Rondônia e Bahia) ou em núcleos especializados em saúde, tal qual ocorre no Distrito Federal, Ceará, Rio Grande do Sul, dentre outros. Experiências institucionais

\footnotetext{
${ }^{102}$ Disponível em: <http://www.cnj.jus.br/noticias/judiciario/86710-direito-a-saude-tribunal-promove-curso-parajuizes-do-ceara> Acesso em: $05 \mathrm{dez} 2018$.
} 
têm surgido como forma de "potencializar os benefícios da judicialização da saúde, bem como reduzir as distorções causadas pela intervenção judicial”' (SANT’ANA, 2013, p.439).

A Defensoria Pública do Estado do Ceará a quem incumbe, conforme Lei Complementar n. ${ }^{\circ}$ 06/97, a prestação gratuita e integral de assistência jurídica, judicial e extrajudicial, aos necessitados, tendo em vista a existência expressiva de demandas ligadas à assistência à saúde, criou, através da Resolução n n 74/2013 do Conselho Superior da Defensoria Pública do Ceará, o Núcleo de Defesa da Saúde (NUDESA).

Em Fortaleza, as demandas da área de saúde continuam sendo as campeãs na busca por atendimento jurídico na Defensoria Pública. Diariamente, cerca de 30 novos pedidos chegam ao NUDESA, que integra o Núcleo Central de Atendimento do órgão, principal porta para quem busca acesso à justiça gratuita em Fortaleza. Durante o ano de 2016, o NUDESA contabilizou 5.667 atuações $^{103}$.

Diante da crescente demanda, a Defensoria criou o programa Defensoria em Ação por Mais Saúde, que estabelece um fluxo administrativo a ser percorrido para evitar o atraso de demandas que podem ser solucionadas extrajudicialmente. O Núcleo de Atendimento Inicial em Saúde (NAIS) foi criado mediante assinatura de convênio, firmado em abril de 2016, entre a Defensoria Pública do Estado do Ceará e as Secretarias da Saúde do Estado e do Município, com objetivo de manter um diálogo permanente entre as partes, fazendo com que as demandas da saúde recebidas na Defensoria Pública do Ceará sejam resolvidas sem a necessidade de judicialização.

Menos de um ano após a assinatura do convênio, 1.889 pessoas já haviam sido atendidas, sendo que $28 \%$ (529) dos pedidos puderam ser resolvidos administrativamente, sem necessidade de entrar na Justiça, o que consistiu em grande avanço, uma vez que no ano 2015, quando não existia essa forma de diálogo, a todas as pessoas que procuraram o núcleo tiveram suas demandas judicializadas ${ }^{104}$.

Quando o assistido procura o Núcleo de Defesa da Saúde da Defensoria Pública, com documentação, guia e prescrição médica, solicitando consulta, exames, medicamentos, cirurgia, material hospitalar, dietas, colchão, cama, cadeira de rodas, fraudas, etc, a Defensoria encaminha o pedido ao Núcleo de Atendimento Inicial em Saúde (Nais), que tem até 10 dias úteis para responder a solicitação, evitando que a Justiça seja acionada.

\footnotetext{
${ }^{103}$ Disponível em: <http://www.defensoria.ce.def.br/noticia/defensoria-e-secretarias-de-saude-municipaisdiscutem-acoes--para-agilizar-demandas-de-saude/>Acesso em:12 jun 2017.

${ }^{104}$ Disponível em:<http://www.defensoria.ce.def.br/noticia/defensoria-firma-convenio-com-unimed--ceara-paraevitar-judicialização-de-demandas/>Acesso em:12 jun 2017.
} 
Após o atendimento do paciente pelo NUDESA, sua demanda passa por uma triagem e caso possa ser solucionada administrativamente é encaminhada por meio informal, por e-mail ou telefone às Secretaria de Saúde do Estado ou do Município. Caso a demanda seja provisória ou substitutiva, poderá ser acionada uma Câmara de Conciliação a fim de promover um entendimento entre o sistema único de saúde e o paciente ${ }^{105}$.

Durante reunião ocorrida em maio de 2018, entre a defensora pública geral do Ceará, Mariana Lobo, o subdefensor público geral do Estado, Leonardo Antônio de Moura Júnior, a supervisora do Núcleo de Defesa da Saúde (NUDESA), Karinne Matos e a procuradora geral do Estado, Carol Gondimo, o então Secretário de Saúde, Henrique Javi, declarou que a economia gerada pelo convênio foi superior a 100 milhões de reais aos cofres do Estado, somente nos dois primeiros anos, acrescentou ainda:

\begin{abstract}
Observamos que, graças a essa ação cooperada, só é judicializado aquilo que realmente é necessário, como nas doenças raras e as condições oncológicas. Isso demonstra que o trabalho tem sido efetivo e pouco a pouco vai se organizando, porque a nossa meta, agora, é ter essa mesma estrutura montada na capital possa ser direcionada para apoiar os defensores públicos em todo o interior do Estado, permitindo a mesma forma de tratamento, pareceres e informações para mitigar ou evitar a judicialização ${ }^{106}$.
\end{abstract}

A defensora e supervisora do Núcleo de Defesa da Saúde (NUDESA), Karinne Matos, destacando a importância da atuação em conjunto das instituições, também frisou que:

Houve uma queda no número de processos de judicialização, pois com essa cooperação estamos conseguindo atender muitas demandas administrativamente. $\mathrm{O}$ papel da Defensoria frente ao sistema de justiça e ao poder público ficou muito ressaltado e a Sesa tem conhecimento de que só é judicializado quando administrativamente não vai ser concedido ${ }^{107}$.

Na opinião da defensora pública geral do Ceará, Mariana Lobo:

[...] a parceria com a Secretaria da Saúde do Estado tem sido no sentido de ajudar a pessoa enferma, assistida pela Defensoria Pública, resolver seu problema em menor tempo possível. Por isso, antes de judicializar, há um diálogo administrativo entre a Defensoria e a Sesa. Este entendimento tem tido resultado importante e nossa intenção é ajustar os passos para avançarmos ainda mais em soluções extrajudiciais na área da saúde ${ }^{108}$.

\footnotetext{
${ }^{105}$ Disponível em: <http://www.oestadoce.com.br/geral/convenio-diminui-judicializacao-na-saude>. Acesso em 04 jan 2018.

${ }^{106}$ Disponível em: <http://www.oestadoce.com.br/geral/convenio-diminui-judicializacao-na-saude>. Acesso em 04 jan 2018.

${ }^{107}$ Disponível em: <http://www.oestadoce.com.br/geral/convenio-diminui-judicializacao-na-saude>. Acesso em 04 jan 2018.

${ }^{108}$ Disponível em: <http://www.oestadoce.com.br/geral/convenio-diminui-judicializacao-na-saude>. Acesso em 04 jan 2018.
} 
A expressiva redução do número de processos atribui-se à parceria com a Defensoria Pública do Estado para evitar a judicialização das demandas da saúde e solucioná-las de forma administrativa. Conforme informações obtidas junto à SESA, a solicitação mais comum na área da saúde é a demanda por medicamentos para pacientes em tratamento de câncer, osteoporose, fibrose cística e doenças raras, que não constam na Relação Nacional de Medicamentos (RENAME) para fornecimento gratuito pelo SUS ou não tem distribuição regulamentada pela ANVISA.

Em visita feita à sede do NUDESA foi indagado quanto a investigação sobre a real condição financeira do paciente, ao que foi informado que inicialmente se faz uma aferição para saber se a parte é mesmo hipossuficiente. Foi ressaltado ainda que, em geral, as demandas por consultas, exames e algumas medicações podem ser obtidas via administrativa, contudo, algumas consultas e exames mais especializados ainda estão sendo objeto de judicialização.

$\mathrm{O}$ atendimento pela Defensoria Pública do Estado requer que o pacientes que tenham sido previamente atendidos pelo SUS. Outra demanda não atendida pela Defensoria, consiste nas demandas por cirurgias ortopédicas, que após ação civil pública que tramitou na $6^{\text {a }}$ Vara da Justiça Federal no Ceará, obedece a uma fila própria e pública, acessada por meio de sistema desenvolvido pela Prefeitura de Fortaleza ${ }^{109}$.

Independentemente de o medicamento ou tratamento ser constar na política de saúde pública, ele será judicializado, com base no direito à saúde. No NUDESA existem dois formulários para preenchimento pelo paciente, um deles relacionado ao medicamento que pertença a lista do SUS e outro se o medicamento não for pertencente à lista.

Acerca da redução da demanda em saúde, foi informado que não houve uma diminuição, mas uma mudança de rito, uma vez que ao invés de judicializados, há uma resolução administrativa das demandas; caso não houvesse a resolução administrativa das demandas a judicialização atingiria nível não suportável pelo núcleo, pois as demandas são crescentes em função também da divulgação que foi feita sobre o referido núcleo à população.

Através dos dados informados pelo Núcleo, se em 2016, o NUDESA contabilizou 5.667 atuações, no ano de 2018, realizou 7.760 atendimentos ${ }^{110}$, o que demonstrou um aumento relevante do número de atuações. Sendo que, do total de solicitações em 2018, 972 delas foram referentes a pedidos de transferências e UTI, conforme dados abaixo:

\footnotetext{
${ }^{109}$ Disponível em: <http://www.cearaagora.com.br/site/lancado-sistema-que-vai-gerenciar-filas-de-cirurgias-emfortaleza/>. Acesso em 04 jan 2018.

${ }^{110}$ Disponível em: < http://www.defensoria.ce.def.br/noticia/defensoria-ultrapassa-800-solicitacoes-de-uti-najustica-em-2018/>. Acesso em 28 jan 2019.
} 
Tabela 11 - Demandas 2018.

\begin{tabular}{c|c|c}
\hline MÊS & TRANSFERÊNCIA & UTI \\
\hline JANEIRO & 31 & 34 \\
FEVEREIRO & 22 & 43 \\
MARÇO & 32 & 44 \\
ABRIL & 32 & 54 \\
MAIO & 25 & 53 \\
JUNHO & 45 & 29 \\
JULHO & 42 & 38 \\
AGOSTOS & 56 & 48 \\
SETEMBRO & 53 & 34 \\
\hline OUTUBRO & 54 & 52 \\
NOVEMBRO & 59 & 36 \\
DEZEMBRO (até 19/12) & 37 & 19 \\
\hline TOTAL & 488 & 484 \\
\hline
\end{tabular}

Fonte: Núcleo de Defesa da Saúde (NUDESA).

Verifica-se que a demanda por leitos de UTI é uma questão que continua a ocupar relevante posição na judicialização dentro do Estado, o que requer uma atuação efetiva por parte dos Poder Executivo para resolução da questão, chegando referido Núcleo a atender em um só dia cerca de 14 pedidos de leito.

Se encontram em funcionamento no interior do Estado e em parte da Região Metropolitana outros Núcleos de atuação do NUDESA, que possibilitam o diálogo entre Defensoria e Secretarias de Saúde nos municípios de Maracanaú, Barbalha, Iguatu e mais recentemente em Aracati ${ }^{111}$. O NUDESA situado na comarca de Fortaleza conta com sede própria, possui três defensores públicos ali lotados e equipe de triagem que compõe o NAIS para definir o que será resolvido administrativamente, composta por colabores terceirizados.

Um fator positivo do encaminhamento das demandas ao Nais consiste no direcionamento, à Secretaria de Saúde do Estado e do Município das solicitações de sua respectiva competência, o que judicialmente não costuma ser considerado, como observa Barroso (2009, p.50): "apesar das listas formuladas por cada ente da federação, o Judiciário vem entendendo possível responsabilizá-los solidariamente, considerando que se trata de competência comum". Esse entendimento em nada contribui para organizar o já complicado

111 Disponível em: <http://www.defensoria.ce.def.br/noticia/acoes-de-saude-passam-a-ser-resolvidas-de-formaadministrativa-em-aracati-apos-parceria-entre-defensoria-e-prefeitura/>. Acesso em 20 jan2018. 
sistema de repartição de atribuições entre os entes federativos. Conforme informações da Assessoria Jurídica da SESA, essa repartição de competências foi um dos motivos que geraram expressiva economia para os cofres do Estado.

Existe uma distinção de competências, realizada pela Defensoria Pública do Estado do Ceará no momento da propositura da ação, uma vez que itens de atenção básica, primária e secundária são demandados contra os Municípios, enquanto do Estado se pleiteia itens de atenção terciária e especializada e medicamentos de alto custo. Através de convênio firmado com a Defensoria Pública da União, ainda, algumas demandas, como por medicamentos oncológicos, superiores à 60 salários mínimos, são encaminhadas para a mesma, para que ingresse contra a União.

O presente arranjo institucional desempenha função de prevenção, atuando como meio de solução administrativa de conflitos, acabando por estimular a interlocução entre as instituições para prevenir a judicialização das demandas. Pode-se dizer que de certa forma acaba também auxiliando gestão, na medida em que possibilita identificar quais as demandas mais recorrentes nas ações, possibilitando uma estratégia de planejamento em saúde, o que pode otimizar o atendimento prestado aos usuários.

A resolução extrajudicial do conflito evita eventual pedido de bloqueio de verbas públicas para efetivação da decisão judicial. Foi ressaltado pelo núcleo que, nos casos de não atendimento da demanda via extrajudicial, que são raros, resultando na sua judicialização, constituem justificativas comuns do Estado e do Município os 'entraves burocráticos de compras'. Sendo assim, outra pergunta se faz: como diminuir as formalidades para a compra de produtos e insumos exigidas por lei, para possibilitar uma efetivação mais célere do direito à saúde? Ou melhor, como evitar o desabastecimento recorrente?

Uma análise inicial do tema parece indicar o fortalecimento de uma visão do caráter multi-institucional do processo de efetivação da Constituição e de proteção do direito à saúde. Para Souza (2011, p.226) atingimos maturidade suficiente para admitir que, "embora seja desejável a intervenção judicial no campo dos direitos sociais, não é possível atribuir a ele o protagonismo no processo, até porque tudo indica que este não seria o caminho mais adequado para a promoção da tão desejada efetividade".

A utilização da mediação como instrumento de concretização do direito fundamental à Saúde, apresenta como características primordiais:

[...] a rapidez e eficácia dos resultados; a redução do desgaste físico e emocional do assistido, que já se encontra abalado com a moléstia que o acomete; a diminuição do custo financeiro para a Administração Pública e para o Poder Judiciário; o controle sobre o efeito nefasto da indústria farmacêutica; a possibilidade de substituição dos 
fármacos prescritos por outros integrantes das portarias regulatórias do Ministério da Saúde ou de menor custo; a garantia de privacidade e sigilo; a diminuição da duração e reincidência de litígios; a não intervenção do Poder Judiciário na execução do orçamento do ente público, o que tem sido ocasionado pelos bloqueios e remanejamentos de verbas públicas para cumprimento das determinações judiciais atinentes ao fornecimento de produtos farmacêuticos e/ou custeio de tratamentos médicos hospitalares; e, primordialmente, a facilitação da comunicação entre o administrado e o administrador, auxiliando este último no processo de formulação de políticas públicas de saúde (QUEIROZ, 2013, p. 170).

Assim, o diálogo firmado entre os gestores das Secretárias de Saúde e os usuários do Sistema Único de Saúde, com a intermediação de Defensores Públicos, consagraria a superação da equivocada ideia de que a concretização dos direitos só se mostra possível por meio da jurisdição (QUEIROZ, 2013).

Esse diálogo é imprescindível, principalmente nas demandas de saúde em que se busca simplesmente a efetivação do Sistema de Saúde já existente. Possibilitando a resolução dos conflitos na esfera administrativa, sem o custo que a máquina judiciária traria a sociedade.

Pode-se considerar como uma das causas da expressiva redução dos gastos da Secretaria de Saúde do Estado com demandas judiciais, a parceria com a Defensoria Pública do Estado para evitar a judicialização das demandas da saúde e solucioná-las de forma administrativa. Mesmo diante dos problemas relatados pelos componentes do NUDESA, os dados da Secretaria de Saúde do Estado do Ceará, permitem verificar o êxito da experiência de diálogo institucional na mitigação da judicialização excessiva e na efetivação das políticas públicas de saúde. Esse convênio tem grande potência para o desenvolvimento de um espaço institucional, com seu espaço institucionalizado, porém ainda em construção. 


\section{CONSIDERAÇÕES FINAIS}

O estudo do desenvolvimento e evolução da Política Pública de Saúde nacional e no âmbito do Estado do Ceará demonstrou extensa normatização e necessidade de estudos técnicos para se conceber um planejamento no âmbito da saúde pública, bem como a existência de todo um aparato técnico administrativo para sua execução. Restou verificada, ainda, a contraposição de duas concepções relacionadas a saúde pública, uma individualista e de consumo e outra coletiva e universalizante do sistema de saúde.

Constatou-se também uma busca constante por excelência na organização dos serviços que por questões financeiras e relacionadas a gestão não desenvolve seu pleno potencial. Desde a implantação do SUS, até os anos atuais, foram desenvolvidas diversas políticas exitosas em nível nacional e local, destacando-se o pioneirismo do Estado do Ceará.

O fato do serviço de saúde ser considerado um serviço público está relacionado ao regime especial que lhe é aplicado, uma vez que o Estado assumiu o dever de prestar essa assistência ele próprio, ainda que não de forma exclusiva, sendo que para alguns autores o serviço de saúde adequado pode ser elevado à categoria de direito fundamental. Referido direito pode ser entendido como desdobramento do direito fundamental à boa administração exigível judicialmente, inclusive pela via principiológica.

Considerando o direito à saúde como direito social, prestacional e de aplicabilidade imediata, deve ser ressaltado, contudo, o caráter político das políticas púbicas que asseguram esse direito diante de seu caráter objetivo, que impõe um planejamento para sua prestação de forma coletiva, a prioridade da ação política é inclusive de previsão constitucional.

Ao se considerar o argumento da capacidade institucional nos termos apresentados por Sunstein e Adrian Vermeule, pode-se sustentar que a discussão sobre a intervenção judicial nas políticas públicas de saúde não está restrita à contraposição entre os princípios do mínimo existencial e da reserva do possível. Face toda a problemática envolvendo a judicialização individual do direito à saúde, que pode dar margem a preferências em sacrifício aos direitos de outrem, à defesa do interesse econômico de determinados agentes privados ou mesmo a um impacto importante em relação ao orçamento destinado ao atendimento das políticas públicas, sendo realista quanto à capacidade institucional do Judiciário, defende-se que essas decisões devem estar cercadas do máximo de conhecimentos técnicos multidisciplinares, exigindo-se uma autocontenção.

A judicialização da saúde deve ser analisada a partir de critérios mínimos, que envolvam as ciências jurídicas e ciências da saúde, que confiram primazia ao direito fundamental a saúde, 
que não pode ser interpretado como direito absoluto, mas deve ser deferido de forma individual de forma a preservar o equilíbrio entre a isonomia substancial dos cidadãos e a sustentabilidade do sistema de saúde.

Através do presente estudo demonstra-se que o modelo de judicialização da saúde de forma irrestrita revela-se insustentável, o que tem provocado uma evolução da jurisprudência reconhecendo-se a necessidade da utilização de critérios legais e auxílio técnico para decisões dos magistrados, de forma a contribuir para uma melhor fundamentação, que garanta um direito à saúde de acordo com a realidade fática, uma vez que, tanto os recursos existentes são limitados, devendo ser dispostos de forma a atender o bem comum, bem como deve ser considerada a totalidade da legislação e principiologia relativa a política pública de saúde assegurada pelo Estado Brasileiro.

Constatou-se a atuação do Conselho Nacional de Justiça, no incentivo a criação dos Comitês da Saúde nos Estados e instalação de órgãos técnicos de auxílio aos magistrados (NAT'S), bem como na produção de Enunciados das Jornadas do Direito à saúde. Todo esse esforço permite que a judicialização no âmbito das políticas públicas de saúde, caso seja necessária, se dê de forma mais democrática, uma vez que se permite discussão dos contornos dessa intervenção com os demais atores do sistema de saúde.

Especificamente do Tribunal de Justiça do Estado do Ceará constatou-se a existência da judicialização de medicamentos, tratamentos e insumos já previstos na política pública do SUS e que por alguma razão não estão sendo acessíveis à população do Estado, restou demonstrada também a predominância da litigância individual e alto índice de deferimento das demandas, seja via liminar ou decisão definitiva e a grande demanda por leitos de UTI.

No âmbito do Estado do Ceará, notadamente a atuação na capacitação de magistrados, por parte do Comitê Executivo de Saúde e Tribunal de Justiça do Estado do Ceará, bem como a instalação do NAT'JUS/CE, demostram o esforço de aprimoramento das relações para, que haja um diálogo mais amplo entre os seus atores a fim de evitar que as decisões judiciais causem um impacto muito grande na política pública coletivamernte planejada.

O Comitê Executivo, por exemplo é um lugar onde podem se exercer os diálogos institucionais, por possuir atores do sistema da saúde e sistema de justiça, esse instrumento é muito importante para o maior desafio da judicialização da saúde, que consiste na institucionalização da política do diálogo e da desjudicialização. Isso também se obtém mediante a capacitação dos agentes do sistema de justiça acerca da legislação sanitária e das políticas públicas de saúde, a fim de aumentar a resolutividade das demandas já existentes e 
evitar que mais casos sejam judicializados, e através de medidas de mediação sanitária, seja através do próprio judiciário ou de outras instituições.

Ao longo do presente estudo, também se verificou que o estabelecimento de um espaço de diálogo interinstitucional, através da criação do NAIS, no Estado do Ceará, de fato, auxiliou na mitigação de demandas judiciais excessivas em saúde. Além dos ganhos institucionais derivados da prática deste diálogo, o principal beneficiário é o próprio usuário do Sistema Único de Saúde, através de uma prestação jurisdicional adequada.

Vê-se que o Tribunal de Justiça do Estado do Ceará (TJCE) vem envidando esforços, juntamente com o Comitê Estadual de Saúde, na busca por soluções não só para o excesso de judicialização na área da saúde, mas também para a judicialização descabida que gera prejuízos aos cofres públicos mediante a criação de políticas públicas por parte dos magistrados.

Em síntese, o presente estudo demonstra que resultados como a desjudicialização da saúde e a autocontenção judicial pode-se obter mediante: 1) uma maior atenção e reforço da capacidade do Judiciário através das medidas adotadas pelo CNJ (comitês, orientações, criação do NAT'S); 2) novos arranjos, com o caso do NAIS, que permitem um verdadeiro diálogo interinstitucional, caracterizado pela resolução extrajudicial de conflitos.

Apesar do sucesso que vem sendo obtido por meio dessas medidas de diálogo, faz-se importante ressaltar que nas duas iniciativas estudadas, NATJUS-CE e NAIS, o mesmo desafio foi encontrado, o aumento natural da demanda e a expansão das iniciativas para outras comarcas do Estado do Ceará, o que requer uma ampliação no quadro de pessoal em atuação nesses setores. Além disso, demonstrado aumento vertiginoso da demanda por leitos de UTI no Estado, cumpre um estudo específico de estratégias para resolução dessa questão. Outro aspecto encontrado ao longo do estudo refere-se a judicialização de itens básicos da política pública de saúde como insumos, tratamentos e medicações que por algum motivo não são de livre acesso por parte da população, que se dirige ao âmbito da Defensoria Pública do Estado, o que requer mais uma vez o constante diálogo entre os atores da justiça e da gestão em saúde a fim de aprimorar a prestação do serviço e evitar a judicialização excessiva. 


\section{REFERÊNCIAS}

ALEXY, Robert. Derechos Individuales y Bienes Colectivos. In: El Concepto y la Validez del Derecho. Trad. Jorge M Sena. Barcelona: Gedisa, 1994.

ALVES, Camila et al. Metodologia da Pesquisa. Fundação Getúlio Vargas. Disponível em: $<$ http://direitorio.fgv.br/sites/direitorio.fgv.br/files/u100/tcc_metodologia_de_pesquisa_20132 .pdf>. Acesso em: 15 mar 2018.

AGUIAR, Zenaide Neto. SUS: Sistema Único de Saúde -antecedentes, percurso, perspectivas e desafios. 2. ed. São Paulo: Martinari, 2015.

ANDRADE, Maria Goreti Macedo Lobo de. Microrregiões de saúde: a experiência do Estado do Ceará. Dissertação apresentada à banca examinadora da Universidade Estadual do Ceará, Curso de Mestrado Profissional em Planejamento e Políticas Públicas, como requisito parcial para a obtenção do título de Mestre em Planejamento e Políticas Públicas. Fortaleza, 2007. Disponível em: <http://livros01.livrosgratis.com.br/cp097845.pdf>. Acesso em: 02 jan 2019.

ARAGÃO, Alexandre Santos de Aragão. Serviços Públicos e Direitos Fundamentais. RFD Revista da Faculdade de Direito da UERJ. v. 1, n 19, jun/dez 2011.

ARGUELHES, Diego Werneck; LEAL, Fernando. Argumento das "capacidades institucionais", entre a banalidade a redundância e o absurdo. Revista Direito, Estado e Sociedade, n.38, jan./jun. 2011. Disponível em: <http://direitoestadosociedade.jur.pucrio.br/media/01_Arguelhes_Leal.pdf >. Acesso em: 03 jun 2017.

Dois problemas de operacionalização do Argumento de "Capacidades Institucionais". Revista Estudos Institucionais, Vol.2, 1, 2016. Disponível em: $<$ http://www.academia.edu/27447373/Dois_problemas_de_operacionaliza\%C3\%A7\%C3\%A 3﹎do_argumento_de_capacidades_institucionais_>. Acesso em 15 jun 2017.

ASENSI, Felipe. PINHEIRO, Roseni. Judicialização da saúde e diálogo institucional: A experiência de Lages (SC). Revista Direito Sanitário, v.17, n.2, São Paulo: jul./out 2016. Disponível em: <http://www.revistas.usp.br/rdisan/article/view/122306> Acesso em: 10 jan 2018.

ATALLAH, Álvaro Nagib. Medicina baseada em evidências. Revista Diagnóstico \& Tratamento. v. 23, ed.02, São Paulo: 2018.

BARATA, Rita Barradas. CHIEFFI, Ana Luiza. Judicialização da política pública de assistência farmacêutica e equidade. Caderno de Saúde Pública. Rio de Janeiro: ago, 2009. Disponível em: <http://www.scielo.br/pdf/csp/v25n8/20>. Acesso em 10 jan 2018.

BARBOSA, José Policarpo de Araújo. Saúde \& Poder: uma história das instituições de saúde pública do Estado do Ceará. Fortaleza: RDS, 2017.

BARCELLOS, Ana Paula de. Neoconstitucionalismo, direitos fundamentais e controle das políticas públicas. Revista Direito Administrativo, Rio de Janeiro, n.240, 2005. 
BARROSO, Luis Roberto. Constituição, democracia e supremacia judicial: Direito e Política no Brasil contemporêneo.In As novas faces do ativismo judicial. Org. André Luiz Fellet, Daniel Giotti de Paula, Marcelo Novelino. Salvador: Editora Juspodivm, 2011.

Da falta de efetividade à judicialização excessiva: direito à saúde, fornecimento gratuito de medicamentos e parâmetros para a atuação judicial. Revista Jurisp. Mineira, Belo Horizonte, a. 60, $\mathrm{n}^{\circ} 188$, p. 29-60, jan./mar. 2009.

BALESTRA NETO, Otávio. A Jurisprudência dos tribunais superiores e o direito à saúde Evolução rumo à racionalidade. Revista de Direito Sanitário. São Paulo, v.16, n.1, p. 87-111, mar./jun. 2015.

BEAUD, Stéphane. WEBER, Florence. Guia para a pesquisa de campo. Produzir e analisar dados etnográficos. Tradução Sérgio Joaquim de Almeida. Revisão e tradução de Henrique Caetano Nardi. 2. ed. Petrópolis, RJ: Vozes, 2014.

BEZERRA, Helga Maria Sabóia. As transformações da noção de serviço público na União Européia: o serviço de interesse geral do Tratado de Lisboa. Direito, Estado e Sociedade. Revista Eletrônica de Direito da PUC. Rio de Janeiro 32/131, jan.jun/2008.

BILHIM, João. Políticas Públicas e agenda política. Valorizar a Tradição: Orações de sapiência no ISCSP. Edition: $1^{\circ}$. Chapter: Politicas públicas e agenda política. Publisher: ISCSP, Ulisboa, Editors: ISCSP, Ulisboa, pp. 82-102. Disponível em: $<$ https://www.researchgate.net/publication/292141803_Politicas_publicas_e_agenda_politica $>$. Acesso em: 10 jul 2017.

BISQUERRA, Rafael; SARRIERA, Jorge Castellá; MARTÍNEZ, Francesc. Introdução à estatística: enfoque informático com o pacote estatístico SPSS. Porto Alegre: Artmed, 2004.

BITTAR, Eduardo Carlos Bianca. $O$ direito na pós-modernidade. Revista Seqüência, $\mathrm{n}^{\mathrm{o}} 57$, dez. 2008.

BRASIL. Lei $n^{\circ}$ 8.080, de 19 de setembro de 1990. Dispõe sobre as condições para a promoção, proteção e recuperação da saúde, a organização e o funcionamento dos serviços correspondentes e dá outras providências. (Lei Orgânica da Saúde). Diário Oficial da União, Brasília, set 1990. Disponível em <http://www.planalto.gov.br/ccivil_03/leis/L8080.htm>. Acesso em: 30 out 2018.

Lei $\mathrm{n}^{\mathrm{o}} 12.401$, de 28 de abril de 2011. Altera a Lei $\mathrm{n}^{\circ} 8.080$, de 19 de setembro de 1990, para dispor sobre a assistência terapêutica e a incorporação de tecnologia em saúde no âmbito do Sistema Único de Saúde - SUS. Diário Oficial da União, Brasília, abr 2011. Disponível em $<$ http://www.planalto.gov.br/ccivil_03/_Ato20112014/2011/Lei/L12401.htm>. Acesso em: 30 out 2018.

Ministério da Saúde. Protocolos Clínicos e Diretrizes terapêuticas. Série A. Normas e manuais técnicos. Vol.1, Brasília: 2010.

. CONSELHO NACIONAL DE JUSTIÇA. Justiça Pesquisa: Judicialização da saúde no Brasil: dados e experiência. Coordenadores: Felipe Dutra Asensi e Roseni Pinheiro. Brasília: Conselho Nacional de Justiça, 2015. 
$\begin{array}{cccc} & \text { CONSELHO NACIONAL DE JUSTIÇA. Justiça em Números. Brasília: } \\ \text { Portal } & \text { CNJ, } & 2017 . & \text { Disponível }\end{array}$ $<$ http://paineis.cnj.jus.br/QvAJAXZfc/opendoc.htm?document=qvw_1\%2FPainelCNJ.qvw\&h ost=QVS 40neodimio03\&anonymous $=$ true $\&$ sheet $=$ shResumoDespFT $>$. Acesso em 10 jul 2017.

CONSELHO NACIONAL DE SECRETÁRIOS DE SAÚDE. SUS Legis Saiba mais sobre o projeto que consolidou as portarias do gabinete do ministro da saúde. Revista Consensus, ano VII, número 25, outubro, novembro e dezembro de 2017, Brasília: CONASS, 2017.2 Disponível em:<http://www.conass.org.br/biblioteca/pdf/revistaconsensus_25.pdf $>$. Acesso em 10 jan 2018.

. CONSELHO NACIONAL DE SECRETÁRIOS DE SAÚDE. Sistema Único de Saúde. Para entender a gestão do SUS, v.1, Brasília: CONASS, 2011. Disponível em: <www.conass.org.br.>. Acesso em 10 jul 2017.

. CONSELHO NACIONAL DE SECRETÁRIOS DE SAÚDE. Direito à saúde. Para entender a gestão do SUS, 2015. $1^{\text {a }}$ edição, Brasília: CONASS, 2015.a. Disponível em: <www.conass.org.br.>. Acesso em 10 jul 2017.

. CONSELHO NACIONAL DE SECRETÁRIOS DE SAÚDE. Sistema Único de Saúde. Para entender a gestão do SUS, v.1, Brasília: CONASS, 2007. Disponível em: <www.conass.org.br.>. Acesso em 10 jul 2017.

Lei $\mathrm{n}^{\circ}$ 8.080, de 19 dezembro de 1990. Dispõe sobre as condições para a promoção, proteção e recuperação da saúde, a organização e o funcionamento dos serviços correspondentes e dá outras providências. Disponível em: <http://www.planalto.gov.br/ccivil_03/leis/18080.htm>. Acesso em: 10 jan. 2018.

Lei $n^{\circ} 13.460$, de 26 de junho de 2017. Dispõe sobre participação, proteção e defesa dos direitos do usuário dos serviços públicos da administração pública. Disponível em: $<$ http://www.planalto.gov.br/ccivil_03/_ato2015-2018/2017/lei/L13460.htm>. Acesso em: 10 jan. 2018.

. MINISTÉRIO DA SAÚDE. Portaria n ${ }^{\circ} 1.820$, de 13 de agosto de 2009. Dispõe sobre os direitos e deveres dos usuários da saúde. Disponível em: $<$ http://conselho.saude.gov.br/ultimas_noticias/2009/01_set_carta.pdf $>$. Acesso em: 10 jan. 2018.

INSTITUTO DE PESQUISA APLICADA. Políticas sociais: acompanhamento e análise, v.1, Brasília: Ipea, 2013.

SUPREMO TRIBUNAL FEDERAL. Audiência Pública - Internação Hospitalar com diferença de classe-SUS. Recurso Extraordinário $\mathrm{n}^{\circ}$ 581.488. Disponível em $<$ http://www.stf.jus.br/arquivo/cms/audienciasPublicas/anexo/TranscricaoInternacaoHospitala r.pdf $>$ Acesso em 15 jun 2018.

Disponível

SUPREMO TRIBUNAL FEDERAL. Recurso Extraordinário $n^{\circ}$ 581.488. 
$<$ http://www.stf.jus.br/arquivo/cms/noticiaNoticiaStf/anexo/RE581488DT.pdf $>$ Acesso em 15 jun 2018.

SUPREMO TRIBUNAL FEDERAL. Suspensão de Tutela Antecipada STA 175. <http://www.stf.jus.br/arquivo/cms/noticianoticiastf/anexo/sta175.pdf> Acesso em 05 out 2018.

BRAVO, Maria Inês Souza. Política de Saúde no Brasil. Este texto é uma versão revista e ampliada dos artigos: "As Políticas de Seguridade Social Saúde". In: CFESS/ CEAD. Capacitação em Serviço Social e Política Social. Módulo III: Política Social. Brasília: UnBCEAD/ CFESS, 2000 e "A Política de Saúde no Brasil: trajetória histórica". In: Capacitação para Conselheiros de Saúde - textos de apoio. Rio de Janeiro: UERJ/DEPEXT/NAPE, 2001. Disponível

em: $<$ http://www.escoladesaude.pr.gov.br/arquivos/File/Politica_de_Saude_no_Brasil_Ines_Bravo .pdf> Acesso em 17 fev 2018.

BRITO, Leila Maria Torraca. O sujeito pós-moderno e suas demandas judiciais. Revista Psicologia: ciência e profissão. Universidade do Estado do Rio de Janeiro, Rio de Janeiro: 2012.

BRITO, Patrícia Ribeiro. Judicialização da Saúde e desarticulação governamental: uma análise a partir da Audiência Pública de Saúde. In Judicialização da saúde: a visão do Poder Executivo/ coordenado por Maria Paula Dallari Bucci e Clarice Seixas Duarte. - São Paulo: Saraiva, 2017.

BUCCI, Maria Paula Dallari. Direito Administrativo e Políticas Públicas. São Paulo: Saraiva, 2002.

Saraiva, 2006.

Políticas Públicas: reflexões sobre o conceito jurídico. São Paulo:

DUARTE, Clarisse Seixas. Judicialização da saúde: a visão do Poder

Executivo/ coordenado por Maria Paula Dallari Bucci e Clarice Seixas Duarte. - São Paulo: Saraiva, 2017.

CARDOSO, Henrique Ribeiro. O paradoxo da Judicialização das Políticas Públicas de Saúde no Brasil. Um ponto cego no Direito? Rio de Janeiro: Lumen Juris, 2016.

CAVALCANTI, Hilda. Brasil tem mais de 240 mil processos na área da saúde. Portal CNJ. 2011. Disponível em: <http://www.cnj.jus.br/noticias/cnj/56636-brasil-tem-mais-de-240-milprocessos-na-area-de-saude>. Acesso em 10 jul 2017.

CARVALHO, Gilson. Os governos trincam e truncam o conceito da integralidade.RADIS Comunicação e Saúde. Rio de Janeiro, v. 49, p. 16, set. 2006.

CARVALHO FILHO, José dos Santos. Manual de direito Administrativo. 26 ed. rev.,ampl. e atual. Até 31-12-2012. São Paulo: Atlas, 2013.

CARVALHO, José Eduardo. Metodologia do trabalho científico. 1. ed. Goiânia: Decklei, 2015.

CAVALCANTI, Hilda. Brasil tem mais de 240 mil processos na área da saúde. Portal CNJ. 2011. Disponível em: <http://www.cnj.jus.br/noticias/cnj/56636-brasil-tem-mais-de-240-milprocessos-na-area-de-saude>. Acesso em 10 jul 2017. 
CEARÁ. Secretaria de Saúde. Plano Estadual de Saúde 2016-2019, 2016. Disponível em: $<$ https://www.saude.ce.gov.br/download/plano-estadual-de-saude-2016-2019/>. Acesso em: 02 jan 2019.

Tribunal de Justiça. Regimento interno do Tribunal de Justiça do Estado do Ceará. Fortaleza: Tribunal de Justiça do Estado do Ceará, 2018, 218p. Disponível em: $<$ https://www.tjce.jus.br/wp-content/uploads/2015/07/Regimento-Interno-TJCE-201828Miolo29-Final.pdf>. Acesso em: 05 dez 2018.

CNJ. Conselho Nacional de Justiça. Brasil tem mais de 240 mil processos na área da saúde. Brasília: CNJ, 2011. Disponível em: <http://www.cnj.jus.br/noticias/cnj/56636-brasil-temmais-de-240-mil-processos-na-area-de-saude>. Acesso em: 12 de out. 2018.

Enunciados da I Jornada de Direito da Saúde. São Paulo: CNJ, 2014. Disponível em<http://www.cnj.jus.br/images/ENUNCIADOS_APROVADOS_NA_JORNADA_DE_DI REITO_DA_SAUDE_\%20PLENRIA_15_5_14_r.pdf> Acesso em: 12 de out de 2018.

Enunciados da II Jornada de Direito da Saúde. São Paulo: CNJ, 2015. Disponível em: http://www.cnj.jus.br/files/conteudo/destaques/arquivo/2015/05/96b5b10aec7e5954fcc19784 73e4cd80.pdf> Acesso em: 12 de out. 2018.

Relatório Justiça em números 2017: ano-base 2016. Brasília: CNJ, 2017. Disponível em http://www.cnj.jus.br/files/conteudo/arquivo/2017/12/b60a659e5d5cb79337945c1dd137496c. pdf. Acesso em: 25 out 2018.

CIOVANELlA, Lígia (org.) Políticas e Sistema de Saúde no Brasil. 2. ed. rev. e amp. I organizado por Lígia Ciovanella, Sarah Escorei, Lenaura de Vasconcelos Costa Lobato et al. Rio de Janeiro: Editora FIOCRUZ, 2012.

COELHO, Vera Maria Câmara; LIMA, Arnaldo Ribeiro Costa. (org.) Ceará 2050: Juntos pensando o futuro. Estudo setorial especial. Fortaleza, 2018. Disponível em: $<$ http://www.fastef.ufc.br/portal/wp-content/uploads/2018/07/ESTUDO-SETORIALESPECIAL-\%E2\%80\%93-SAUDE.pdf>. Acesso em: 02 jan 2019.

CORNEJO, Valentin Thury. Juez y division de poderes hoy. Madrid: Editorial Ciudad, 2002.

CORREIA, André BrayanLima. Cada cidadão válido representa uma parte da riqueza do Estado. Revista História e Culturas. v. 2. n. 4. Jul-dez. 2014. Disponível em: <https://revistas uece.br/index.php/revistahistoriaculturas/article/view/380/296>. Acesso em 02 jan 2019.

CORVINO, Juliana Diniz Fonseca. A crise do sistema único de saúde e o fenômeno da judicialização da saúde. Rio de Janeiro: Gramma, 2017.

CUNHA, Murilo Bastos da. Fontes da informação em ciência e tecnologia. Brasília: Briquet de Lemos, 2001. 
DALLARI, Sueli Gandolfi; NUNES JÚNIOR, Vidal Serrano. Direito sanitário. São Paulo.Ed.Verbatim, 2010.

D’AVILA, Ana Luiza; POZ, Mario Roberto Dal. A Reforma do Sistema de Saúde no Brasil e o Programa de Saúde da Família. PHYSIS: Rev. Saúde Coletiva, Rio de Janeiro, 2005, 15(Suplemento):p. 225- 264.Disponível em: <https://www.scielosp.org/pdf/physis/2005.v15suppl0/225-264>. Acesso em 02 jan 2019.

DELDUQUE, Maria Célia. CASTRO, Eduardo Vazquez. A Mediação Sanitária como alternativa viável à judicialização das políticas de saúde no Brasil. Saúde Debate. v. 39, n. 105, Rio de Janeiro: abril/jun 2015. Disponível em: http://www.scielo.br/scielo.php?script=sci_abstract\&pid=S0103$11042015000200506 \& \operatorname{lng}=p t \& t \operatorname{lng}=\mathrm{pt}>$. Acesso em 10 jul 2017.

DUARTE, Bernardo Augusto Ferreira. Direito à saúde e teoria da argumentação: em busca da legitimidade dos discursos jurisdicionais. Belo Horizonte: Arrais Editores, 2012.

DUARTE, Clarice Seixas. Inovações de Método para o trabalho jurídico. A experiência do grupo de pesquisa direitos sociais e políticas públicas. In Judicialização da saúde: a visão do Poder Executivo /coordenado por Maria Paula Dallari Bucci e Clarice Seixas Duarte. - São Paulo: Saraiva, 2017.

DUGUIT, Léon. Traité de Droit Constitutionnel. $2^{\circ}$ ed., vol.II, Paris, Ancienne Librairie Fontemoing \& Cia. Éditeurs, 1923.

ESPÍNDOLA, Angela Araújo da Silveira; WEIDLICH, Amanda de Morais. Judicialização e ativismo: as distorções decorrentes da excessiva concretização judicial da assistência terapêutica. Revista Paradigma. Ribeirão Preto, SP, a.XX, v.24, n.1, p.121-150. Jan./Jun.2015.

EPSTEIN, Lee. KING, Gary. Pesquisa empírica em direito: As regras de inferência. Título original: The rules of inference. Vários tradutores. São Paulo: Direito GV, 2013.

FÁVERO, L. P. et al. Análise de dados - modelagem multivariada para tomada de decisões. Rio de Janeiro: Elsevier, 2009.

FIGUEIREDO, Mariana Filchtiner. Direito fundamental à saúde: parâmetros para sua eficácia e efetividade. Porto Alegre: Livraria do Advogado, 2007.

FERRAZ JUNIOR, Tércio Sampaio. A ciência do direito. 3. ed. São Paulo: Atlas, 2014.

FREITAS. Juarez. Direito Fundamental à boa Administração Pública. 3. ed. São Paulo: Malheiros, 2014.

FINGER, Ana Cláudia. Serviço Público: Um instrumento de concretização de direitos fundamentais. A\&c Revista de Direito Administrativo e Constitucional. Ano 3, n.11, jan/fev./mar. 2003. Belo Horizonte: Fórum, 2003.

FINKELMAN, Jacobo (Org.) Caminhos da saúde pública no Brasil./Organizado por JacoboFinkelman. Rio de Janeiro: Editora Fiocruz, 2002. 
GADELHA, Georgina. Sob o signo da distinção: formação e atuação da elite médica cearense (1913-1948). Rio de Janeiro. Tese de doutorado apresentada ao Programa de Pós-graduação em História das Ciências e da Saúde da Casa Oswaldo Cruz - Fio Cruz, 2012.

GARCIA FILHO, José Carlos. Serviços Públicos e Direitos Fundamentais. A\&c Revista de Direito Administrativo e Constitucional. Ano 3, n.11, jan/mar. 2003. Belo Horizonte: Fórum, 2003.

GIL, Antonio Carlos. Como elaborar projetos de pesquisa. 5. ed. São Paulo: Atlas, 2010.

GRAU, Eros Roberto. A ordem econômica na Constituição de 1988. 7. ed. São Paulo: Malheiros, 2002.

GROTTI, Dinorá Adelaide Musetti. O serviço público e a Constituição brasileira de 1988. São Paulo: Malheiros, 2003.

HACHEM, Daniel Wunder. A dupla titularidade (individual e transindividual) dos direitos fundamentais econômicos, sociais, culturais e ambientais. Revista de Direitos Fundamentais e Democracia, v.14, n.14, Curitiba, p.618-688, jul./dez.2013.

Direito fundamental ao serviço público adequado e capacidade econômica do cidadão: repensando a universalidade do acesso à luz da igualdade material. $A \& C$ - Revista de Direito Administrativo \& Constitucional, Belo Horizonte, ano 14, n. 55, p. 123 158, jan./mar. 2014.

HENRIQUES, Fátima Vieira. Direito Prestacional à Saúde e Atuação Jurisdicional. In SARMENTO, Daniel; SOUZA NETO, Claúdio Pereira de (Org.). Direitos Sociais. Fundamentos, Judicialização e Direitos Sociais em Espécie. Rio de Janeiro: Lumen Juris, 2008.

JÉZE, Gaston. Principios Generales del Derecho Administrativo, vol.II, Buenos Aires, Depalma, 1948.

JUNIOR, Américo Bedê Freire. O controle Judicial de políticas públicas. São Paulo: Editora Revistados Tribunais, 2005.

JUNIOR, Osvaldo Canela. Controle Judicial de Políticas Públicas. São Paulo: Saraiva, 2011.

KRELL, Andeas J. Direitos Sociais e controle judicial no Brasil e na Alemanha. Porto Alegre. Sergio Antônio Fabris, 2002.

LEITE, Vanessa Gomes Leite. Reflexos da judicialização da saúde no acesso igualitário à políticas públicas: a questão dos leitos de UTI no Estado do Ceará. Dissertação de Mestrado. Universidade Federal do Ceará, Faculdade de Direito, Programa de Pós-Graduação em Direito, Fortaleza, 2016.

MACEDO, Maiara Batalini De. A Judicialização da saúde pública e o diálogo institucional: Os espaços interinstitucionais como garantia fundamental de acesso a saúde. Dissertação apresentada como requisito parcial à obtenção do título de Mestre em Direito da Universidade Federal de Uberlândia. Uberlândia, MG, 2016. Disponível em: 
<https://repositorio.ufu.br/bitstream/123456789/18331/1/JudicializacaoSaudePublica.pdf>. Acesso em: 24 jun 2017.

. A Judicialização da Saúde Pública e o Diálogo Institucional como garantia de equidade social. In Acesso à justiça I [Recurso eletrônico on-line] organização CONPEDI/UFMG/ FUMEC/DomHelder Câmara; coordenadores: Juvêncio Borges Silva, Tereza Cristina Sorice Baracho Thibau, Edinilson Donisete Machado - Florianópolis: CONPEDI, 2015.

Disponível em: https://www.conpedi.org.br/publicacoes/66fs1345/4qiqydiv/ODP1RYOOq7KmFuzR.pdf>. Acesso em: 2 jan 2019.

MACHADO SEGUNDO, Hugo de Brito Machado. O Direito e sua Ciência. São Paulo: Malheiros, 2016.

MACHADO, Maíra Rocha (Org.) Pesquisar empiricamente o direito. São Paulo: Rede de Estudos Empíricos em Direito, 2017.

MÂNICA, Fernando Borges. Teoria da reserva do possível: direitos fundamentais a prestações e a intervenção do Poder Judiciário na implementação de políticas públicas. Revista Brasileira de Direito Público, Belo Horizonte, v. 5, n. 18, p. 169-186, jul./set. 2007. Disponível em: < http://fernandomanica.com.br/site/wpcontent/uploads/2015/10/teoria_da_re serva_do_possivel.pdf >. Acesso em:04 jun 2017

MAPELLI JÚNIOR, Reynaldo. Judicialização da saúde: regime jurídico do SUS e intervenção na Administração pública. 1.ed. - Rio de Janeiro: Atheneu, 2017.

MARQUES NETO, Floriano de Azevedo. A nova Regulamentação dos Serviços Públicos. Revista eletrônica de Direito Administrativo. Salvador, n. 1, fev/març/abril. 2005.

MARIANO, Cynara Monteiro. Emenda Constitucional 95/2016 e o teto dos gastos públicos: o Brasil de volta ao estado de exceção econômico e ao capitalismo do desastre. Revista de Investigações Constitucionais, Curitiba, vol.4, n.1, p.259-281, jan./abril.2017.

; FURTADO, Emanuel Teófilo; ALBUQUERQUE, Felipe Braga; PEREIRA, Fabrícia Helena Linhares Coelho da Silva. Diálogos Sanitários Interinstitucionais e a experiência de implantação do NAT-JUS. Revista de Investigações Constitucionais, Curitiba, vol. 5, n. 1, p. 169-188, jan./abr. 2018.

; PEREIRA, Fabrícia Helena Linhares Coelho da Silva. Mais um obstáculo ao SUS: o caso dos planos de saúde populares. A\&C - Revista de Direito Administrativo e Constitucional, ano 18, n. 72, p. 115-132, ab./jun. 2018.

MARMELSTEIN, George. Curso de Direitos Fundamentais. 6.ed.rev., atual. e ampl. São Paulo: Atlas, 2016.

MEDAUAR, Odete. Serviços públicos e serviços públicos de interesse econômico geral. InUma avaliação das tendências contemporâneas do direito administrativo. MOREIRA NETO, Diogo de Figueiredo (Coord.). Rio de Janeiro: Renovar, 2003. 
MELLO, Celso Antônio Bandeira. Curso de Direito Administrativo. - 33 ed, rev. e atual. até a Emenda Constitucional 92, de 12.7.2016. São Paulo: Malheiros, 2016.

Malheiros, 2017. Serviço público e concessão de serviço público. São Paulo:

MIRANDA, Ciro Carvalho. SUS, Medicamentos, Protocolos Clínicos e o Poder Judiciário: Ilegitimidade e Ineficiência. Brasília: Editora Kirion, 2013.

MONTESUMA, Francisca Gomes; FÉ, Marcia Andréia Barros Moura; GOMES, Silvia Cristina Costa; FERNANDES, Teresa Cristina de Lima; SAMPAIO, José Jackson Coelho. Saúde Pública no Ceará: uma sistematização histórica. Caderno da Escola de Saúde Pública, Ceará. 2(1):6-19, jan./jun.2006. Disponível em: <http://cadernos.esp.ce.gov.br/index.php/cadernos/article/view/28/9>. Acesso em 02 jan 2019.

MORAES, Filomeno. Constituição econômica brasileira: história e política. Curitiba: Juruá, 2011.

NARANJO, Ernan Santiesteban. RAMOS, Santa Taciana Carrilo. Metododogia da Investigação Científica. Angola: Escolar Editora, 2014.

NUNES, Antônio José Avelãs. Breve reflexão sobre o chamado estado regulador. Revista Sequência, nº 54, UFSC, Florianópolis, SC, Brasil, jul.2007.

OCKÉ-REIS, Carlos Octávio. SUS: o desafio de ser único. Rio de Janeiro: Editora Fiocruz, 2012.

OLIVEIRA, Daniela Olímpio. Desjudicialização, acesso à justiça e teoria geral do processo. Curitiba: Juruá, 2015.

OLIVEIRA, Maria Marly de. Como fazer pesquisa qualitativa. Petrópolis, Vozes, 2007.

OLIVEIRA, Régis Fernandes de. Curso de Direito Financeiro. São Paulo: RT, 2006.

PAIM, Jairnilson Silva. Reforma sanitária brasileira: contribuição para a compreensão e crítica [online]. Salvador: EDUFBA; Rio de Janeiro: FIOCRUZ, 2008.

PAIM, Jairnilson Silva et al. O Sistema de Saúde brasileiro: histórias, avanços e desafios. Disponível em: <https://www.passeidireto.com/arquivo/6082122/2-o-sistema-de-saudebrasileiro---historia-avancos-e-desafios>. Acesso em 10 jan 2018.

PASSOS, Daniel Silva. Intervenção Judicial nas Políticas Públicas: o Problema da legitimidade. São Paulo: Saraiva, 2014.

PASSOS, Daniela Veloso; GOMES, Valéria Bastos. A Judicialização da saúde e as políticas públicas para fornecimento de medicamentos: uma análise a partir das decisões do TRF da $5^{\mathrm{a}}$ Região. Revista de Estudos Empíricos em Direito. vol. 4, n. 3, out 2017, p. 98-110.

PEREIRA, Fabrícia Helena Linhares Coelho da Silva Pereira. Direito à saúde: entre o dever estatal e a participação privada. Dissertação de Mestrado apresentada ao Programa de Pós- 
Graduação em Direito da Faculdade de Direito da Universidade Federal do Ceará, como requisito parcial para obtenção do Título de Mestre em Direito. Fortaleza, 2018. Disponível em: $<$ http://www.repositorio.ufc.br/bitstream/riufc/36829/1/2018_dis_fhlcspereira.pdf >. Acesso em: 02 jan 2019

PIRES, Thiago Magalhães. Pós-positivismo sem traumas: O possível e o indesejável no reencontro do Direito com a Moral. As novas faces do ativismo judicial. Org. André Luiz Fellet, Daniel Giotti de Paula, Marcelo Novelino. Salvador: Editora Juspodivm, 2011.

POUPART, Jean. A entrevista de tipo qualitativo: considerações epistemológicas, teóricas $e$ metodológicas. In POUPART, J. et al. A pesquisa qualitativa: enfoque epistemológicos e metodológicos. Trad. Ana Cristina Nasser. Petrópolis: Vozes, 2008.

RAMOS JÚNIOR, Alberto Novaes; NUNES, Carlos Francisco Oliveira. Judicialização do direito à saúde na região Nordeste, Brasil: dimensões e desafios. Caderno de Saúde Coletiva, 2016, Rio de Janeiro, v.24, n.2, p:192-199.

ROCHA, Eduardo Braga. A justiciabilidade do direito fundamental à saúde no Brasil. 1. ed. São Paulo: Letras Jurídicas, 2011.

SAMPIERI, Roberto Hernandez; COLLADO, Carlos Fernández; LUCIO, María del Pilar Baptista. Metodologia de Pesquisa. Editora: Mcgraw Hill. 2006.

SANTOS, Lenir. SUS: Contorno Jurídicos da integralidade da atenção à saúde. In. Keinert, Tânia Margarete Mezzomo; Paula, Silvia Helena Bastos de; Bonfim, José Ruben de Alcântara. As ações judiciais no SUS e a promoção do direito à saúde. São Paulo, Instituto de Saúde, 2009.

. MONTI, José Fernando Casquel. É preciso desjudicializar a saúde como uma das medidas de salvação do SUS. CEBES - Centro Brasileiro de Estudos em Saúde. (Publicado em 2015) Disponível em: http://cebes.org.br/2015/06/e-preciso-desjudicializar-asaude-como-uma-das-medidas-de-salvacao-do-sus/ Acesso em 02 jun 2017.

SARLET, Ingo Wolfgang. A eficácia dos direitos fundamentais. Uma teoria geral dos direitos fundamentais na perspectiva constitucional.10 ed. rev. atual. eampl. Porto Alegre: Livraria do Advogado Ed., 2009.

A Titularidade simultaneamente individual e transindividual dos direitos sociais analisada à luz do exemplo do direito à proteção e promoção à saúde.In $\mathrm{O} \mathrm{CNJ}$ e os desafios da efetivação do direito à saúde. Coordenadores: Milton Augusto de Brito Nobre; Ricardo Augusto Dias da Silva; apresentação de Gilmar Ferreira Mendes. 2.ed. Belo Horizonte: Fórum, 2013. efetividade do direito a saúde na Constituição de 1988. Revista Eletrônica sobre a Reforma do Estado, Salvador, n. 11, set.out.nov. 2007. Disponível em: $<$ http://www.direitodoestado.com/revista/rere-11-setembro-2007-ingo\%20sarlet.pdf $>$. Acesso em: 30 jun 2017.

FIGUEIREDO. Mariana Filchtiner. $O$ direito fundamental à proteção e promoção da saúde no Brasil: principais aspectos e problemas. Disponível 
em:<https://d24kgseos9bn1o.cloudfront.net/editorajuspodivm/arquivos/ingo.pdf $>$ Acesso em: 10 jan 2018.

FIGUEIREDO. Mariana Filchtiner. O direito fundamental à proteção e promoção da saúde na ordem jurídica constitucional: uma visão geral sobre o sistema (público e privado) de saúde no Brasil. Revista Gestão e Controle. Tribunal de Contas do Estado de Rondônia. Ano 1, n. 1, jan/jun. 2013. Disponível em:<http://ojs.tce.ro.gov.br/ojs/index.php/TCE-RO/article/view/3> Acesso em: 10 jan 2018.

SARMENTO, Daniel. Supremacia do Interesse Público? As colisões entre direitos fundamentais e interesses da coletividade. In Direito Administrativo e seus novos paradigmas. (coords) Alexandre Santos Aragão e Floriano de Azevedo Marques Neto. Belo Horizonte, Fórum, 2012.

O Neoconstitucionalismo no Brasil: riscos e possibilidades. As novas faces do ativismo Judicial. As novas faces do ativismo judicial. Org. André Luiz Fellet, Daniel Giotti de Paula, Marcelo Novelino. Salvador: Editora Juspodivm, 2011.

SANTOS, Lenir. SUS: Contorno Jurídicos da integralidade da atenção à saúde. In. KEINERT, Tânia Margarete Mezzomo; PAULA, Silvia Helena Bastos de; BONFIM, José Ruben de Alcântara. As ações judiciais no SUS e a promoção do direito à saúde. São Paulo: Instituto de Saúde, 2009.

SCAFF, Fernando Facury. Reserva do Possível, Mínimo Existencial e Direitos Humanos. In PIRES, Adilson Rodrigues; TÔRRES, Heleno Taveira. (Org). Princípios de Direito Financeiro $e$ Tributário. Estudos em homenagem ao Professor Ricardo Lobo Torres. Rio de Janeiro: Renovar, 2006.

SCAFF, Fernando Facury; NUNES, Antônio José Avelãs. Os tribunais e o direito à saúde. Porto Alegre: Editora Livraria do Advogado, 2011.

SCHIER, Adriana da Costa Ricardo. Palestra apresentada no I CONGRESSO DA REDE DOCENTE EUROLATINOAMERICANA DE DIREITO ADMINISTRATIVO, no painel "Serviços Públicos e atividade econômica como meios de desenvolvimento", às $10 \mathrm{~h}$ do dia 24.02.2011, na Pontifícia Universidade Católica do Paraná.

SCHULZE, Clenio Jair. Enunciados do CNJ sobre saúde pública. Parte I e II. Revista Empório do Direito, 2016. Disponível em: <http://emporiododireito.com.br/leitura/enunciados-do-cnjsobre-saude-publica-parte-i-por-clenio-jair-schulze> Acesso em: 05 out 2018.

SCHULZE, Clenio; GEBRAN NETO, João Pedro. Direito à saúde à luz da judicialização. Porto Alegre: Verbo Jurídico, 2016.

SILVA, Alexandre Barbosa da. SCHULMAN, Gabriel. (Des)judicialização da saúde: mediação e diálogos interinstitucionais. Revista bioética, v.25, n.2, 2017. Disponível em: $<$ revistabioetica.cfm.org.br/index.php/revista_bioetica/article/view/1365.>. Acesso em 10 jan 2018.

SILVA, José Afonso da. Aplicabilidade das normas constitucionais . $3^{\mathrm{a}}$ ed. São Paulo: Malheiros Editores Ltda, 1998. 
SILVA, Virgílio Afonso. O judiciário e as políticas públicas: entre transformação social e obstáculo à realização dos direitos sociais. In Claúdio Pereira de Souza Neto \& Daniel Sarmento. Direitos sociais: fundamentação, judicialização e direitos sociais em espécie. Rio de Janeiro: Lumen Juris, 2008:587-599.

SILVEIRA, Denise Tolfo. CÓRDOVA, Fernanda Peixoto. A pesquisa científica. In: Métodos de Pesquisa. Orgs: Gerhardt, Tatiana Engel e Silveira, Denise Tolfo. Universidade Aberta do Brasil - UAB/UFRGS e pelo Curso de Graduação Tecnológica - Planejamento e Gestão para o Desenvolvimento Rural da SEAD/UFRGS. - Porto Alegre: Editora da UFRGS, 2009.

SOUZA, Jorge Munhós de. Diálogo institucional e direito à saúde. Dissertação apresentada como requisito parcial à obtenção do título de Mestre em Direito na Universidade do Estado do Rio de Janeiro, RJ, 2011. Disponível em: $<$ https://oatd.org/oatd/record?record=oail\%3Awww.bdtd.uerj.brl\%3A1929>. Acesso em: 10 jan 2018.

SUNSTEIN, Cass; HOLMES, Stephen. R. The cost of rights: why liberty dependes on taxes. Nova Iorque: W.W. Norton \& Company, 1999.

TERRAZAS, Fernanda Vargas. O Poder judiciário como voz institucional dos pobres. Disponível em: <http://bibliotecadigital.fgv.br/ojs/index.php/rda/article/viewFile/8047/6837>. Acesso em: 20 fev 2018.

TRAVASSOS, Denise Vieira. Judicialização da saúde e Sistema Único de Saúde: estudo de casos de três tribunais estaduais. Tese de Doutorado. Universidade Federal de Minas Gerais, Faculdade de Odontologia, Programa de Pós-Graduação em Odontologia, Belo Horizonte, 2012.

VELOSO, Marcelene Dias da Paz. Judicialização da Política Pública: o diálogo como forma de concretização da saúde preventiva. Dissertação apresentada como requisito parcial à obtenção do título de Mestre em Direito na Universidade Federal do Pará, Belém, 2015. Disponível em: <http://ppgd.propesp.ufpa.br/ARQUIVOS/dissertacoes/DISSERTA\%C3\%87\%C3\%830\%20 MARCELENE\%20REVISADA\%2021.10.2015.pdf>. Acesso em: 10 jan 2018.

VIEIRA, Fabíola Sulpino. As ações judicias e direito à saúde: reflexão sobre a observância aos princípios do SUS. Revista de Saúde Pública. 2008. v.42, n. 2, p:365-369. 


\title{
ANEXO A - Termo de Cooperação Técnica nº 07/2016
}

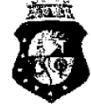 \\ GOVERNO Do \\ Estado do CeArá
}

\begin{abstract}
TERMO DE COOPERAÇÃO TÉCNICA DE SERVIÇOS DE SUPORTE TÉCNICO MÉDICO E FARMACÊUTICO DE ASSISTENNCLA À SAÚDE QUE ENTRE SI CELEBRAM O TRIBUNAL DE JUSTICCA DO ESTADO DO CEARA, O ESTADO DO CEARÁ, O MUNICÍPIO DE FORTALEZA-CE E O HOSPITAL UNIVERSITÁRIO WALTER CANTÍDIO-UFCIEBSERH - Empresa Brasileira de Serviços Hospitalares (PROCESSO ADMINISTRATIVO No51699846.2016.8.06.0000)
\end{abstract}

\section{TCT $N^{0} 07 / 2016$}

Pelo presente instrumento particular, as partes, o TRIBUNAL DE JUSTIÇA DO ESTADO DO CEARÁ, inscrito no CNPJ/MF n ${ }^{\circ}$ 09.444.530/0001-01, situado no Centro Administrativo Governador Virgilio Távora, Cambeba, Fortaleza-CE, doravante denominado TJCE, neste ato representado pela sua Presidente, Desembargadora MARIA IRACEMA MARTINS DO VALE, o ESTADO DO CEARÁ, neste ato representado pelo Senhor Governador Camilo Sobreira de Santana, através da SECRETARIA DE SAÚDE DO ESTADO DO CEARÁ, inscrita no CNPJ n ${ }^{\circ}$ 07.954.571/0001-04, sediada à Avenida Almirante Barroso, $\mathrm{n}^{\circ}$ 600, Praia de Iracema, Fortaleza/CE, doravante denominada SESAP/CE, neste ato representada pelo seu Secretário de Estado de Saúde do Ceará, Dr. Henrique Jorge Javi de Sousa, o MUNICIPIO DE FORTALEZA-CE, Dr. Roberto Cláudio Rodrigues Bezerra, brasileiro, casado, médico, residente e domiciliado em Fortaleza-CE, inscrito no CPF/MF sob o $\mathrm{n}^{\circ}$ 542.116.383-00, portador da cédula de identidade $\mathrm{n}^{\circ}$ 92021001415, através da SECRETARIA MUNICIPAL DE SAÚDE, inscrita no CNPJ n 04.885.197/0001-44, sediada à Rua do Rosário, $\mathrm{n}^{\circ}$ 283, Centro, doravante denominada SMS/CE, neste ato representada pela Secretária Municipal de Saúde de Fortaleza, Dra. Maria do Perpétuo Socorro Martins Breckenfeld e o HOSPITAL UNIVERSITÁRIO WALTER CANTÍDIO-UFC/EBSERH - Empresa Brasileira de Serviços Hospitalares, inscrito no CNPJ n ${ }^{\circ} 07.272 .636 / 0002-12$, sediado à Rua Capitão Francisco Pedro, $\mathrm{n}^{\circ} 1290$, Rodolfo Teófilo, neste ato representado pelo seu Superintendente, Dr. José Luciano Bezerra Moreira, acordam em celebrar o presente TERMO DE COOPERAÇÃO TÉCNICA DE SERVIÇOS DE SUPORTE TÉCNICO MÉDICO E FARMACÊUTICO DE ASSISTÊNCIA À SAÚDE para Prestação de Serviços de Suporte Técnico para Assistência à Saúde que se regerá pelas cláusulas e condições abaixo aduzidas:

$$
\text { Cláusula Primeira-Do Objeto }
$$

1.1. O presente Termo de Cooperação Técnica tem por objeto a cooperação mutua na elaboração de documentos técnicos e especializados na área da saúde para auxiliar magistrados das Varas da Fazenda Pública, do Tribunal de Justiça, dos Juizados Especiais da Fazenda Pública e da Turma Recursal da Fazenda Pública, na formação de um juízo de valor por ocasião da apreciação das 


\section{3 \\ GOVERNO Do \\ ESTADO do CEARÁ}

questões clínicas apresentadas nas ações Judiciais envolvendo a assistência à saúde pública, na forma da Recomendação ${ }^{\circ} 31$, de 30 de março de 2010, do CNJ.

1.2. Os documentos técnicos mencionados no item anterior são denominados pareceres e/ou notas técnicas que deverão ser solicitados diretamente pelos Magistrados à Câmara Técnica, na forma estabelecida na Cláusula Segunda deste Instrumento.

1.3. A prestação de serviços de que trata o presente Contrato deverá contemplar as seguintes informações:

a) Análise do caso concreto apresentado no processo judicial para a qual será elaborado parecer;

b) mapeamento bibliográfico específico para cada caso, por profissional devidamente qualificado;

c) Informações sobre a possibilidade de substituição do medicamento ou procedimento médico prescrito por outro oferecido pelos SUS, e em caso negativo, a justificativa para a não utilização do protocolo SUS.

Cláusula Segunda - Da Descrição dos Serviços

2.1. A prestação de serviços de que trata o presente Termo de Cooperação consiste na elaboração dos seguintes documentos técnicos, que serão produzidos segundo avaliação técnica dos profissionais vinculados à Câmara Técnica, com base na solicitação do Magistrado:

a) Respostas Técnicas rápidas para casos que não seja necessário levantamento bibliográfico complexo, mas que demande informação qualificada imediata.

b) Notas Técnicas abrangendo casos específicos e complexos que demandem revisão bibliográfica, análise de cenário, informações sobre o custo unitário, recomendação sobre riscos e benefícios da liberação ou não da tecnologia fora do protocolo SUS.

2.2. Caberá a SESAP/CE, a SMS/CE, e ao HOSPITAL UNIVERSITÁRIO fornecerem ao TJ/CE o suporte técnico para prestação dos serviços de que trata o presente Termo de Cooperação.

2.3. Os documentos técnicos elaborados pela Câmara Técnica terão assinatura institucional e servirão como banco de dados para consolidação dos entendimentos formados pela Câmara.

\section{Cláusula Terceira - Da Formação e Funcionamento da Câmara Técnica}

3.1. A Câmara Técnica será formada por Médicos e Farmacêuticos do quadro de servidores efetivos dos entes colaboradores, indicados pelos respectivos representantes legais.

3.2. Os Médicos e Farmacêuticos que compõem a Câmara Técnica terão um mandato de dois anos, prorrogável por igual período.

3.3. A remuneração e compensação de horas ou da jornada de trabalho será decidida internamente entre os profissionais e o seu órgão de origem.

3.4. O funcionamento da Câmara Técnica, que se dará preferencialmente por meio eletrônico, será regulamentado mediante Portaria da Presidente do Tribunal de Justiça.

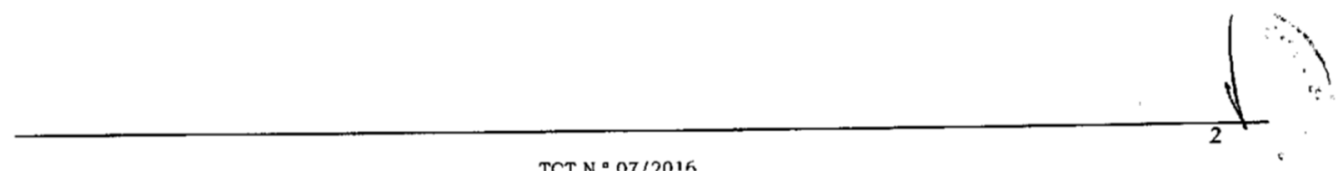




\section{3 \\ GOVERNO do \\ EsTado do CEARÁ}

\section{Cláusula Quarta - Do Prazo de Entrega dos Pareceres}

4.1. Os documentos técnicos mencionados no item 2.1 deste Termo de Cooperação, solicitados pelo TJ/CE, deverão ser entregues nos prazos abaixo especificados, a partir da data do recebimento da solicitação, enviado por meio eletrônico, salvo na hipótese de impedimento ou imperiosa necessidade do serviço, devidamente comprovada:

- Respostas Técnicas Rápidas $=5$ (cinco) dias úteis.

- Notas Técnicas $=5$ (cinco) dias úteis.

\section{Cláusula Quinta - Dos Deveres dos Profissionais da Câmara Técnica}

5.1. Os profissionais que formam a Câmara Técnica prestarão o compromisso legal de bem e fielmente prestarem suas atividades de forma neutra e imparcial, visando apenas a solução da lide na melhor forma possível do direito à saúde. Os profissionais, ao tomar posse, assinarão Termo de Compromisso em relação aos deveres anteriormente mencionados.

5.2. Atender às demandas dos Magistrados de forma diligente e tempestiva fornecendo-lhe os pareceres, respostas rápidas e/ou notas técnicas bem como recomendar o Magistrado sobre a melhor alternativa de esclarecimento da questão técnica envolvida no processo judicial.

5.3. Garantir total sigilo sobre todos os dados e informações que a equipe tenha acesso durante o desenvolvimento dos trabalhos.

5.4. Prestar os esclarecimentos necessários aos Magistrados sobre as informações relativas à natureza e andamento dos serviços executados ou em execução.

5.5. Disponibilizar o acesso a todo o serviço produzido, além de informações necessárias sobre o mesmo, sempre que solicitado.

5.6. Elaborar relatórios contendo os serviços prestados e temas que foram objeto das consultas dos Magistrados, contendo o número do processo e a identificação das partes, sempre que necessário.

5.7. Garantir aos Magistrados do TJ/CE qualidade técnica dos documentos técnicos elaborados.

Cláusula Sexta - Das Obrigaçōes dos Entes Cooperados

Para consecução dos objetivos deste Termo de Cooperação Técnica:

6.1. Compete ao TJ/CE:

6.1.1. Disponibilizar o espaço físico, móveis, equipamentos e demais instrumentos necessários ao adequado funcionamento da Câmara Técnica, indicando até dois funcionários para auxiliarem na prestação dos serviços.

6.1.2. Estimular os Magistrados a consultar a Câmara Técnica antes de proferirem decisões relativas ao fornecimento, pelo Poder Público, de medicamentos, insumos para a saúde, exames, diagnósticos, tratamentos médicos e insumos nutricionais;

6.2. Competem ao ESTADO DO CEARÁ, através da Secretaria de Estado da Saúde; ao MUNICÍPIO DE FORTALEZA, através da Secretaria de Municipal de Saúde e ao HOSPITAL UNIVERSITÁRIO WALTER CANTÍDIO-UFC: 


\section{(3) \\ GOVERNO DO \\ Estado do CEARÁ}

6.2.1. Disponibilizar 03 (três) Médicos e 03 (três) Farmacêuticos dando, os quais serão postos a disponibilidade da Câmara Técnica, sem prejuízo de suas funções ordinárias no órgão de origem, para um mandato de 02 (dois) anos, prorrogável por igual periodo, para auxiliarem aos Magistrados nas ações que tenham por objeto compelir o fornecimento de medicamentos, insumos para a saúde, exames de diagnósticos, tratamentos/procedimentos médicos e cirúrgicos; 6.2.2. Arcar com as despesas de pessoal, referentes aos profissionais da área de saúde que irão atuar no auxílio aos Magistrados;

\section{Cláusula Sétima - Dos Recusros Orçamentários}

7.1. Para a execução do objeto deste Termo de Cooperação não haverá transferências de recursos, de qualquer modalidade, entre os entes participantes.

Cláusula Oitava - Da Vigência e dos Aditivos

8.1. O presente Termo de Cooperação Técnica terá a vigência de 04 (quatro) anos a partir da data de sua assinatura, podendo ser prorrogado ou alterado, através de Termo Aditivo, desde que não haja modificação do objeto aprovado.

\section{Cláusula Nọna-Da Denúncia}

9.1. O presente Termo de Cooperação Técnica poderá ser denunciado a qualquer tempo, no caso de infrigência de qualquer uma das cláusulas e condições nele estipuladas, mediante comunicação escrita, com a antecedência mínima de 30 (trinta) dias ou, ainda, a qualquer tempo, em face da superveniência de impedimento legal que o torne inexequível.

\section{Clausula Décima - Da Fundaméntaçáo}

10.1 Fundamenta-se o presente Instrumento:

a) No art. 116, da Lei Federal n. 8.666/93;

b) No Parecer da Consultoria Jurídica da Presidência, datado de 13/09/2016, devidamente aprovado pela Presidência do TJCE.

\section{Cláusula Décina Primeira-Do Foro}

11.1 Os Convenentes elegem a Comarca de FORTALEZA/CE, no que couber, para dirimir os litígios decorrentes de sua execução, ressalvadas as disposições contidas na Constituição Federal e na Constituição do Estado do Ceará.

\section{Cláusula Décima Segunda - Da Publicação}

12.1 O TJ/CE, SESAP, SMS e UFC, no prazo de 20 (vinte) dias, a contar da assinatura deste documento, providenciarão a competente publicação do Termo, em extrato, através de imprensa oficial respectiva de cada um dos entes. 


\section{3. \\ GOVERNO DO \\ ESTADO do CEARÁ}

\section{Cláusula Décima Terceira - Das Disposições Transitórias}

13.1 As partes praticarão, reciprocamente, os atos necessários à efetiva execução das presentes disposições, por intermédio dos seus representantes, sendo os casos omissos resolvidos conjuntamente pelos Convenentes.

13.2 O TJ/CE, SESAP, SMS e UFC providenciarão, até o $5^{\circ}$ (quinto) dia útil do mês seguinte da assinatura deste Termo de Cooperação Técnica, o encaminhamento de cópias deste instrumento ao Tribunal de Contas do Estado do Ceará e à Coordenadoria de Contabilidade Analítica de suas respectivas Secretarias.

$\mathrm{E}$ por estarem de acordo, depois de lido achado conforme, o presente TERMO DE COOPERAÇÃO TÉCNICA é devidamente assinado pelas partes, em 05 (cinco) vias de igual teor.

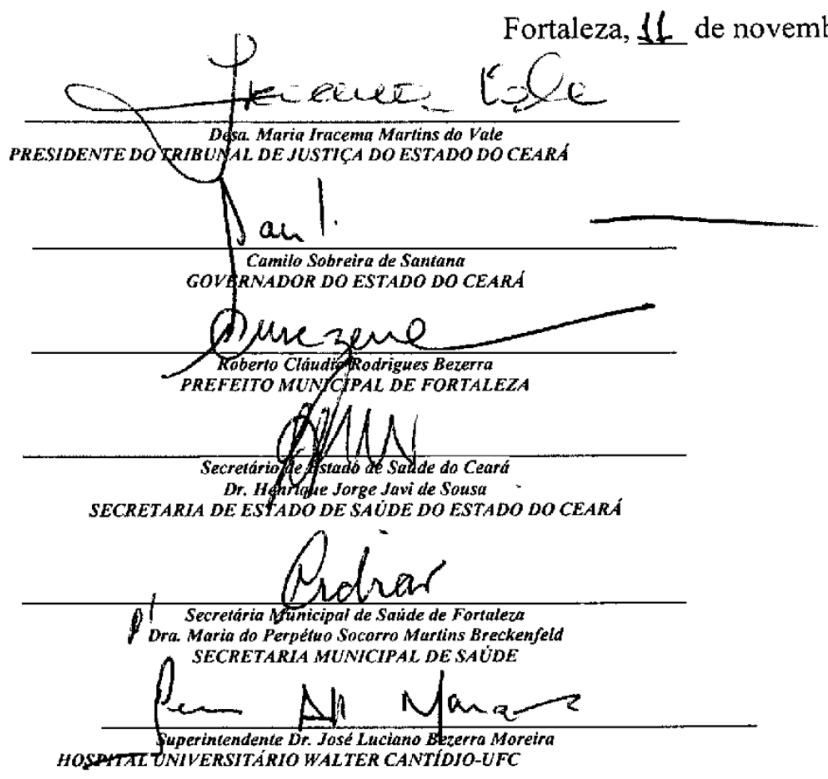

TESTEMUNHAS: 
ANEXO B - Resolução no 74/2013

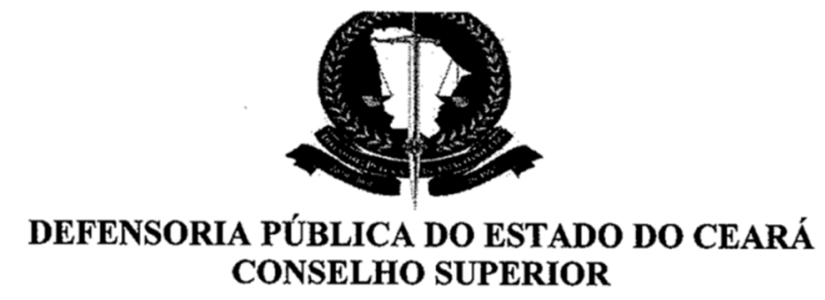

Resolução no 74/2013

INSTITUI E REGULAMENTA, No ÂMBITO DA DEFENSORIA PÚBLICA DO ESTADO DO CEARÁ, O NÚCLEO DE DEFESA DA SAÚDE (NUDESA), E DÁ OUTRAS PROVIDÊNCIAS.

CONSIDERANDO a necessidade de instituição e regulamentação do funcionamento do Núcleo de Defesa da Saúde da Defensoria Pública do Estado do Ceará (NUDESA);

CONSIDERANDO o poder normativo do Conselho Superior no âmbito da Defensoria Pública do Estado do Ceará, conforme art. $6^{\circ}$-B, inciso I, da Lei Complementar 06/97;

CONSIDERANDO a assistência jurídica integral e gratuita aos necessitados, direito e garantia fundamental de cidadania, inserido no art. $5^{\circ}$, LXXIV e art. 134, da Constituição Federal;

CONSIDERANDO que o direito à saúde possui previsão constitucional, nos termos do art. 196 e seguintes da Constituição Federal;

CONSIDERANDO o reconhecimento e garantia dos direitos fundamentais preconizados pela Constituição Federal, Estatuto do Idoso, Código de Defesa do Consumidor, Lei nº. 8.080/1990 e Lei $n^{\circ}$. Lei $9.656 / 98$.
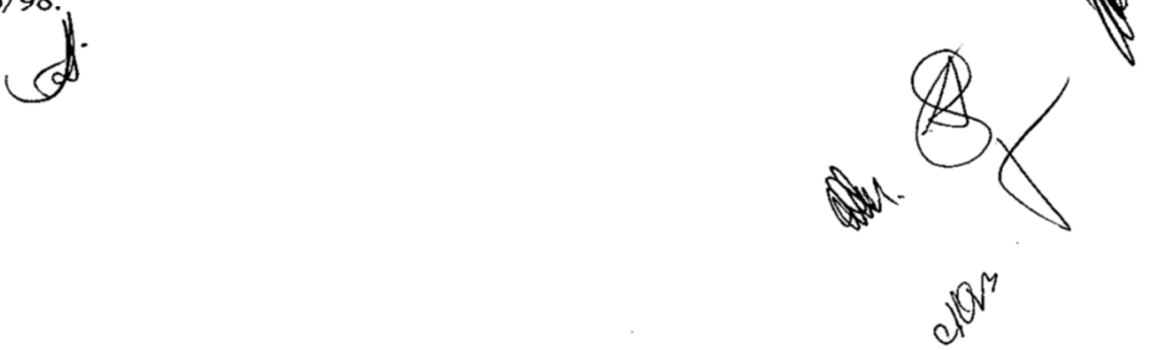


\section{(D. \\ DEFENSORIA PÚBLICA DO ESTADO DO CEARÁ \\ CONSELHO SUPERIOR}

\section{RESOLVE:}

Artigo $1^{\circ}$. Instituir e regulamentar o funcionamento do Núcleo de Defesa da Saúde da Defensoria Pública do Estado do Ceará (NUDESA).

Artigo $2^{\circ}$. O NUDESA terá espaço adequado, com preferência nas proximidades dos órgãos de proteção à saúde, em razão da urgência da matéria abordada.

$\S 1^{\circ}$. O atendimento aos assistidos e aos seus familiares ocorrerá de segunda a sexta-feira, das 08:00 às 17:00 horas.

$\S 2^{\circ}$. Na eventualidade de urgências, o supervisor do NUDESA poderá estender os dias e horários de atendimento mencionados no $\S 1^{\circ}$.

$\S 3^{\circ}$. Terão prioridade, no atendimento, os casos de perigo de morte, dano irreparável ou de difícil reparação, pessoas idosas e portadores de doença grave ou de deficiência.

$\S 4^{\circ}$. O NUDESA será composto, no mínimo, por dois Defensores Públicos, diante da complexidade e da urgência das demandas na área de saúde.

$\S 5^{\circ}$ Nas faltas, férias, ausências e impedimentos, dos Defensores Públicos do NUDESA, estes serão substituídos por designação do Defensor Público Geral;

$\S 6^{\circ} \mathrm{O}$ acompanhamento dos processos ajuizados pelo Núcleo competirá ao Defensor Público que atua perante o respectivo órgão de atuação para onde foi distribuído o feito, que poderá requerer o auxílio dos Defensores Públicos do NUDESA;

$\S 7^{\circ} \mathrm{O}$ Núcleo será supervisionado por um membro da Defensoria Pública, a ser designado pelo Defensor Público- Geral;
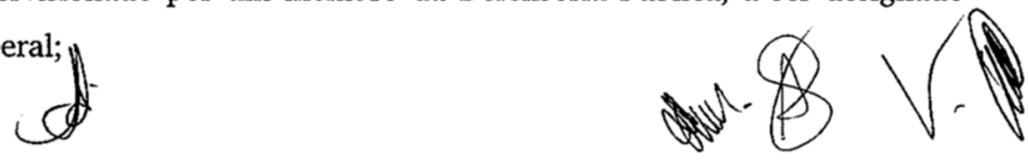


\section{(D. \\ DEFENSORIA PÚBLICA DO ESTADO DO CEARÁ CONSELHO SUPERIOR}

$\S 8^{\circ}$. Ao NUDESA será assegurada estrutura administrativa necessária ao desenvolvimento de suas atribuições.

$\S 9^{\circ}$. O NUDESA terá sua abrangência de atuação:

a) Na capital;

b) Nas comarcas onde não houver Defensor Público em atuação, por designação do Defensor Público- Geral do Estado, sempre que a atuação da Defensoria Pública se justificar pela importância da matéria.

Artigo $3^{\circ}$. O NUDESA atuará judicial e extrajudicialmente, de forma individual ou coletiva, na promoção e defesa do direito à saúde, abrangendo quaisquer situações em que a negativa, omissão ou deficiência da prestação do serviço de saúde, sejam por entes públicos ou privados, venha colocar em risco ou agravar o estado de saúde do assistido, inclusive o fornecimento de medicamentos e quaisquer equipamentos necessários à saúde e à vida.

Parágrafo Único. A atuação do Núcleo não abrange as questões relativas às cláusulas econômico-financeiras em planos de saúde.

Artigo $4^{\circ}$. São Atribuições do NUDESA, por meio de seus órgãos de atuação:

I - Prestar atendimento inicial, orientação jurídica e realizar diligências, que entender necessárias, na temática do direito à saúde;

II - Fazer encaminhamentos das partes a outros serviços da rede de atendimento à saúde, fazendo o monitoramento dos casos de urgência;

III - Realizar visitas técnicas aos órgãos e entidades públicos e privados do sistema de saúde;

IV - Elaborar minuta de convênio entre a Defensoria Pública e entidades relacionadas à saúde, a fim de aprimorar a atuação do Núcleo;

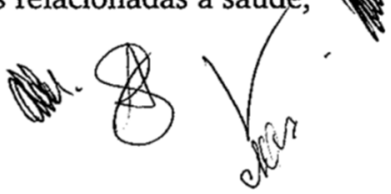




\section{Q. \\ DEFENSORIA PÚBLICA DO ESTADO DO CEARÁ CONSELHO SUPERIOR}

V - Criar cartilha explicativa informando e orientando os profissionais da área da saúde sobre os direitos dos pacientes;

VI - Ministrar palestras, cursos e treinamentos para os profissionais de saúde;

VII - Atuar nas questões extrajudiciais dos assistidos junto à administração pública estadual e municipal, e, ajuizar ações junto ao Poder Judiciário, isolada ou concorrentemente com outros órgãos de atuação da Defensoria Pública;

VIII - Atuar no $2^{\circ}$ Grau de jurisdição, nas causas ajuizadas pelo Núcleo, na função de assessoramento dos órgãos de atuação respectivos, mediante designação específica do Defensor Público- Geral do Estado;

IX - Realizar a orientação técnica, mediante consulta, aos Defensores Públicos do Estado do Ceará, em relação ao direito à saúde;

X - Prestar orientação jurídica à população, mediante atendimento ao público e a realização de audiências públicas, quando se mostrarem necessárias, no âmbito de suas atribuições;

XI - Informar e conscientizar a população a respeito do direito fundamental à saúde, com o apoio da assessoria de comunicação da Defensoria Pública Geral do Estado e do Centro de Estudos e Aperfeiçoamento da Defensoria Pública;

XII - Elaborar, anualmente, planejamento estratégico sobre sua área de atuação;

XIII - Representar a Instituição perante conselhos de direitos, por qualquer de seus membros, mediante designação do Defensor Público- Geral do Estado;

XIV - Firmar compromisso para ajustamento de conduta;

XV - Encaminhar e acompanhar propostas de elaboração, revisão e atualização legislativa na área do Direito à Saúde;

XVI - Representar junto ao Sistema Interamericano de Proteção aos Direitos Humanos, propondo as medidas cabíveis e acompanhando essas açõe
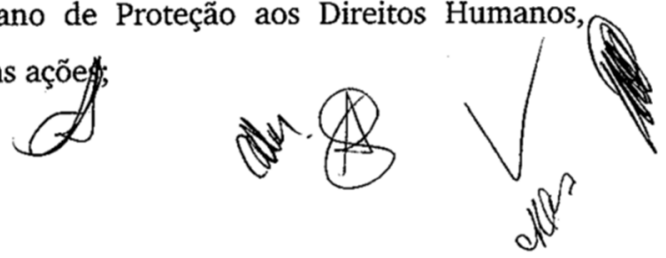


\section{(1). \\ DEFENSORIA PÚBLICA DO ESTADO DO CEARÁ CONSELHO SUPERIOR}

Artigo $5^{\circ}$. O NUDESA para viabilizar o exercício de suas atividades fins, deverá:

I - Manter banco de dados próprio com informações, sempre atualizadas, de legislação, doutrina e experiências pertinentes a sua área de atuação;

II- Possuir, em seu acervo, pesquisa de material não jurídica sobre a área de saúde;

III - Manter banco de dados acerca das entidades com atuação na área de saúde;

Parágrafo único. O NUDESA compartilhará todas as informações acima com os outros órgãos de atuação da Defensoria Pública do Estado do Ceará.

Artigo $6^{\circ}$. Os casos omissos serão resolvidos pelo Conselho Superior da Defensoria Pública Geral do Estado do Ceará.

Artigo $7^{\circ}$. Esta resolução entrará em vigor na data de sua publicação, revogando as disposições em contrário.

Publique-se.

CONSELHO SUPERIOR DA DEFENSORIA PÚBLICA GERAL DO ESTADO DO CEARÁ, em Fortaleza(CE), em 01 de fevereiro de 2013.

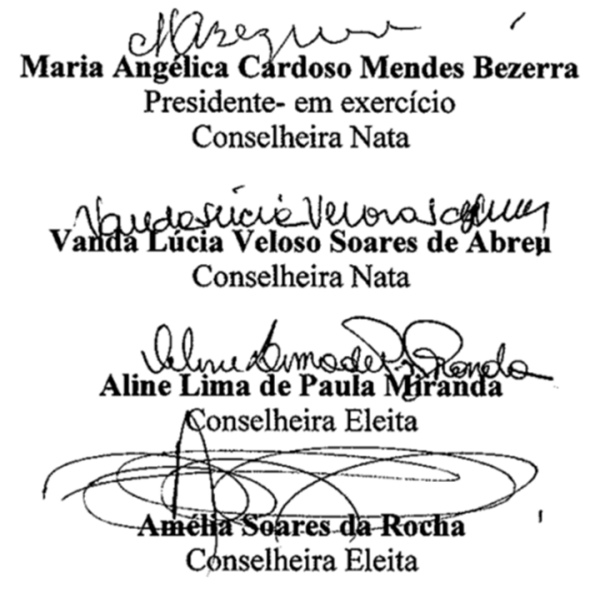


ANEXO C - Resolução no 137/2016

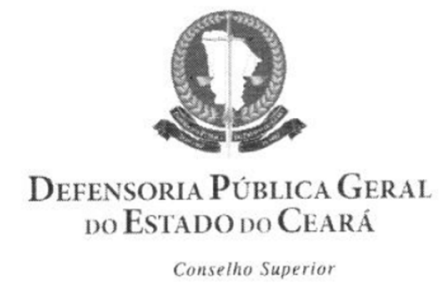

RESOLUÇÃO N $137 / 2016$

Altera a Resolução n 74/2013, que dispõe sobre o Núcleo de Defesa da Saúde - NUDESA.

O CONSELHO SUPERIOR DA DEFENSORIA PÚBLICA GERAL DO ESTADO DO CEARÁ, nO USO de suas atribuições legais,

CONSIDERANDO que ao Conselho Superior da Defensoria Pública do Estado do Ceará compete exercer as atividades consultivas, normativas e decisórias (Art. $6^{\circ}$-B, I e VI da Lei Complementar Estadual n 06/97), no âmbito da Defensoria Pública Geral do Estado do Cerará;

CONSIDERANDO que é função institucional da Defensoria Pública prestar gratuita e integral assistência jurídica, judicial e extrajudicial, aos necessitados, promovendo, extrajudicialmente, a conciliação entre as partes em conflito de interesses, nos termos dos artigos $2^{\circ}$ e $3^{\circ}$, I, da Lei Complementar 06/97;

CONSIDERADO a criação e implantação do "Projeto Defensoria em Ação. Por mais Saúde" que busca a resolução extrajudicial de demandas da saúde, através de convênios com o Estado do Ceará, o Município de Fortaleza e os Planos de Saúde, com a realização de solicitações prévias de atendimento administrativo e realização de conciliações/mediações;

RESOLVE,

Art. $1^{\circ}$. Fica acrescido os incisos XVII no artigo $4^{\circ}$ da Resolução $n^{\circ} 74 / 2013$, com a seguinte redação:

"Art. $4^{\circ}$. 
Defensoria Pública Geral

DOESTADO do CEARÁ

Conselho Superior

XVII - Desenvolver o "Projeto Defensoria em Ação. Por Mais Saúde", na vigência dos convênios assinados com a administração pública Estadual e/ou Municipal e/ou Planos de Saúde, buscando atendimento administrativo prévio das demandas de saúde apresentadas pelos assistidos, antes do ajuizamento de ações judiciais, sempre que possível, e realizando audiências de conciliação/mediação, nos casos cabíveis, além de debates temáticos sobre tratamentos de saúde em conjunto com interessados e especialistas da área. "

Art. $2^{\circ}$. Esta resolução entrará em vigor na data de sua publicação, revogando as disposições em contrário.

Publique-se.

CONSELHO SUPERIOR DA DEFENSORIA PÚBLICA GERAL DO ESTADO DO CEARÁ, em Fortaleza (CE), 17 de outubro de 2016.

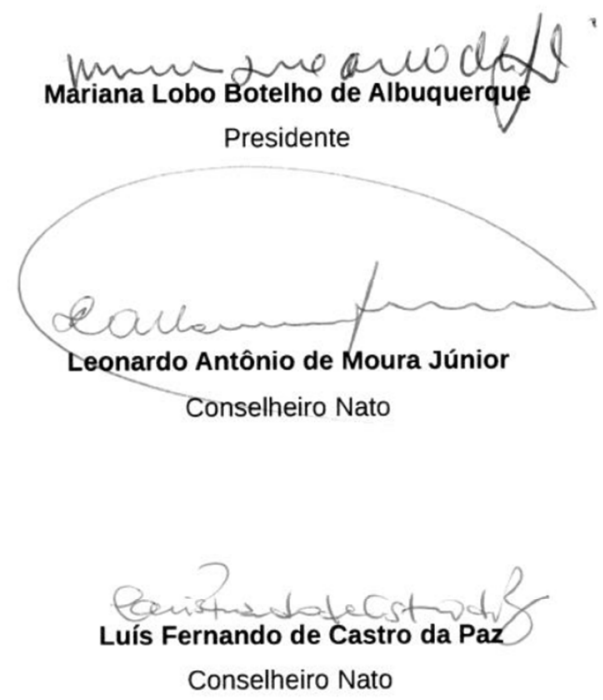

Av. Pinto Bandeira, $n^{\circ}$ 1.111, Luciano Cavalcante, Fortaleza-CE CEP 60.811-370, Fone: (85) 3278-7855 